Mirta Zaida Lobato/Sofia Venturoli (eds.) Formas de ciudadanía en América Latina

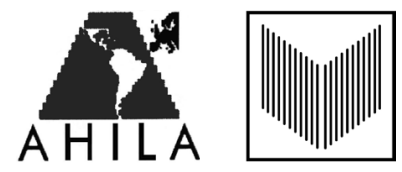


Estudios AHILA de Historia Latinoamericana N. ${ }^{\circ} 10$

Editor General de AHILA:

Manuel Chust

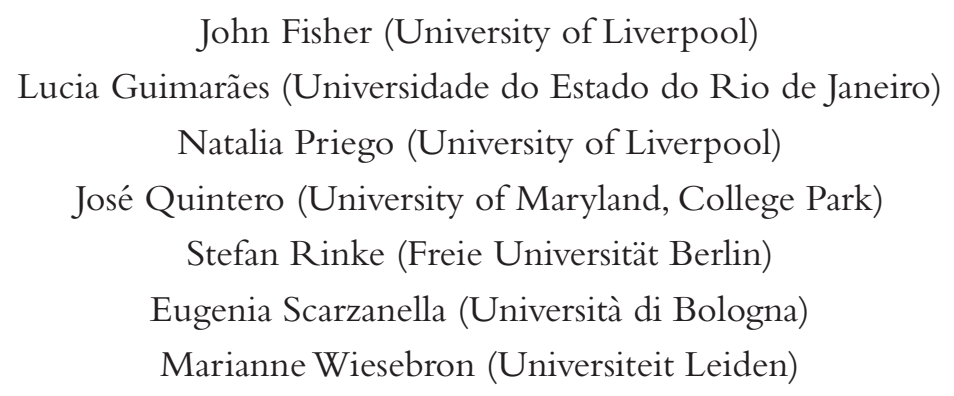

Estudios AHILA de Historia Latinoamericana es la continuación de Cuadernos de Historia Latinoamericana 
Asociación de Historiadores Latinoamericanistas Europeos

\section{FORMAS DE CIUDADANÍA EN AMERICA LATINA}

Mirta Zaida Lobato y Sofia Venturoli (eds.) 
Reservados todos los derechos

(C) AHILA, Asociación de Historiadores Latinoamericanistas Europeos www.ahila.nl

(C) Iberoamericana, 2013

Amor de Dios, 1 - E-28014 Madrid

Tel.: +34 914293522

Fax: +34 914295397

info@iberoamericanalibros.com

www.ibero-americana.net

(C) Vervuert, 2013

Elisabethenstr. 3-9 - D-60594 Frankfurt am Main

Tel.: +49695974617

Fax: +49695978743

info@iberoamericanalibros.com

www.ibero-americana.net

ISBN 978-84-8489-774-3 (Iberoamericana)

ISBN 978-3-86527-322-7 (Vervuert)

Depósito Legal: M-32849-2013

Cubierta: c.f. diseño y comunicación

Impreso en España

The paper on which this book is printed meets the requirements of ISO 9706 


\section{ÍNDICE}

Introducción. Formas de ciudadanía en América Latina

Mirta Zaida Lobato y Sofia Venturoli

\section{PersPeCtivas históricas}

La ciudadanía y su dimensión política en la América Latina decimonónica

Flavia Macías

Modernidad, modernización y sufragio universal: la experiencia de Argentina, Brasil, Chile y Uruguay

Verónica Giordano

Identidades, ciudadanía y etnicidad. Perspectivas históricas

María E. Argeri

La construcción histórica de la ciudadanía social en Argentina. Una lectura de largo plazo

Juan Suriano

\section{NUEVAS FORMAS DE CIUDADANÍA}

Los ciudadanos y ciudadanas menores del Perú Jeanine Anderson y Helen Palma Pinedo 
Inacabadas: etnicidades y ciudadanías sustantivas en México y Perú ...

Sofia Venturoli y Francesco Zanotelli

Democracia participativa e cidadania no Brasil

Marianne Wiesebron

Bibliografia general

173

Sobre los autores y las autoras ..................................................... 191 


\title{
INTRODUCCIÓN \\ FORMAS DE CIUDADANÍA EN AMÉRICA LATINA
}

\author{
Mirta Zaida Lobato \\ Sofia Venturoli
}

\begin{abstract}
El uso de la palabra 'ciudadanía' se ha extendido en los últimos años hasta abarcar diferentes dimensiones relacionadas con la construcción de derechos. El término aparece en el Diccionario de la Real Academia Española con tres acepciones: cualidad y derecho del ciudadano, conjunto de los ciudadanos de un pueblo o nación, comportamiento propio de un buen ciudadano. En portugués la primera acepción es también cualidades del ciudadano y en inglés refiere tanto al estado de tener los derechos, privilegios y deberes de ciudadano como al comportamiento en término de deberes, obligaciones y funciones del ciudadano. El diccionario de política de Norberto Bobbio, Nicola Matteucci y Gianfranco Pasquino, editado por primera vez en español en 1981 y en italiano en 1976, omite su entrada. ¿Quiere decir esto que la política no incluye la dimensión de la ciudadanía como parte de cualquier análisis de los derechos y deberes de la población? ¿No está relacionada con las ideas de constitucionalismo, federalismo, feminismo, democracia, derecho, justicia? La observación precedente y los interrogantes no buscan una respuesta retórica, más bien lo que se intenta destacar es que los debates sobre la ciudadanía en los marcos de las diferentes ciencias sociales están situados históricamente y estrechamente relacionados con las lógicas disciplinares e institucionales y que, por eso, es posible trabajar sobre diferentes temporalidades, asincronías y desigualdades en la configuración no sólo del concepto de ciudadanía, sino
\end{abstract}


también en el propio proceso histórico en el que se construyeron sus múltiples dimensiones.

Reinhart Koselleck habla del "potencial semántico y pragmático" de algunos conceptos, y en esta compilación nosotras queremos dar cuenta de ese potencial para el concepto de "ciudadanía". Su construcción es compleja, heterogénea y de ningún modo progresiva ni en América Latina ni en otras geografias. Asimismo, aunque el término ciudadanía puede rastrearse hasta la Antigüedad clásica, lo cierto es que fue en el siglo xx cuando se conceptualiza sistemáticamente. Además, fue a raíz del texto de T. H. Marshall, publicado en 1950, que el término ciudadanía se asoció con derechos y temporalidades. El argumento es ampliamente conocido: los derechos civiles se obtuvieron en el siglo XVIII; los derechos políticos, en el xIX y los sociales y económicos, en el $\mathrm{Xx}, \mathrm{y}$ todos ellos son igualitarios y universalistas.

Sin embargo, las formas de la ciudadanía no siguen un camino unívoco. No hay una sola ruta y las cuestiones en debate se van modificando a lo largo del tiempo, por eso puede pensarse en el rasgo de "inacabadas", sugerido en el título de uno de los capítulos que también deja abierto el camino a nuevas u otras interpretaciones. En muchos países latinoamericanos el tema de la ciudadanía entró en la agenda de investigación en la década de 1980 en los marcos de una sistemática revisión de las nociones de representación y legitimidad democrática. Muchas veces, la datación es precisa. María Emilia Prado (2005: 18-19) afirma que, desde la promulgación de la Constitución de 1988 en Brasil, uno de los países más grandes de la región, el debate intelectual y político se ha ido concentrando cada vez más en el ejercicio de los derechos civiles y políticos, ya que, de algún modo, se había resuelto el del derecho a la participación política mediante el voto universal. Los contenidos y los rasgos de las formas de ciudadanía que pueden considerarse "históricas" fueron colocados bajo la lupa crítica y reformulados y revisitados tanto desde perspectivas históricas como filosóficas y sociológicas. ${ }^{1}$ Lo que estaba en cuestión eran los dilemas de las rutas del liberalismo, del republicanismo y del comunitarismo en la configuración del concepto de ciudadanía a la luz de los cambios políticos y sociales del último cuarto del siglo xx.

En buena parte de la literatura histórica y sociológica, la noción de ciudadanía está articulada con la construcción de los Estados nacionales. La edi-

Véase Sabato (1999), Carvalho (1985) y, como parte de una discusión más general, Mouffe (1992) y Pateman (1988), entre otros. 
ficación de esos Estados en América Latina hunde sus raíces en el proceso independentista y, por eso, el debate sobre la ciudadanía ha tenido algunos sesgos. Por un lado, la importancia que tuvo en su constitución la idea de universalidad, relacionada a su vez con las de libertad e individualidad (de modo que se plantearon una serie de exclusiones, a veces enunciadas y otras de hecho) y, por otro, el énfasis en la dimensión política de la ciudadanía, lo que produjo el desplazamiento de las otras dimensiones, como la social y civil. El proceso de redefinición y de ampliación de este concepto llevó a incluir una dimensión cultural incorporando nociones como colectividad, diferencia e identidad, en particular en relación con realidades étnicas diversas presentes en los países latinoamericanos. En el proceso de abarcar nuevas y diferentes significaciones y contenidos, el concepto de ciudadanía no solamente se amplió, sino que superó la idea de adquisición de derechos legales. El énfasis en la dimensión cultural permitió también hablar de ciudadanías en plural; es decir, evidenció la necesidad de considerar y formular diferentes ciudadanías de acuerdo con el contexto histórico y cultural, resultando visible la importancia de la dimensión temporal y procesual. El pensamiento neoliberal estableció un estrecho vínculo entre esa amplia idea de ciudadanía y el mercado: ser un ciudadano significa también la individual integración en el mercado como consumidor y como productor. "En un contexto en que el estado se retira gradualmente de su rol de garante de derechos el mercado está ofreciendo un subrogado de instancia de ciudadanía" (Dagnino 2005: 8). De esta manera, obscurece la dimensión política de la ciudadanía y, en muchos casos, lleva a paradigmas excluyentes, ya sea en las normas jurídicas, ya sea en las prácticas ciudadanas.

Ya desde la década de 1960 una parte de la literatura sociológica, filosófica e histórica ha cuestionado el paradigma igualitarista de la modernidad reemplazándolo por el de "diferencia". Como todo concepto, la noción de diferencia no está separada de su contexto, pero lo importante es que, a partir de entonces, tiene una valoración positiva frente al carácter jerárquico y desigual de su construcción en el pasado. Por eso se produce una búsqueda del reconocimiento de la diferencia. Entonces la condición de desigualdad y el reconocimiento de la diferencia, tanto en las condiciones como en las oportunidades que existen en el ejercicio de la ciudadanía para hombres y mujeres, para las personas de diferentes razas y/o etnias y de culturas diversas, son clave para pensar que la búsqueda de la igualdad ha dado lugar a la aplicación de políticas concretas que corrijan las situaciones de injusticia. Se fueron diseñando así modelos de discriminación positiva; 
una de esas expresiones es la política de cuotas, a favor de colectivos marginados. $^{2}$

La discusión alrededor de la universalidad y de la igualdad que impregnaron los debates sobre la ciudadanía dibujó otra dimensión cuando se plantearon que las minorías religiosas, étnicas y nacionales también tienen derechos ciudadanos. Will Kymlicka (1996), desde la filosofia política, ha defendido una "ciudadanía multicultural", especialmente en el contexto actual. Como mencionamos antes, la dimensión cultural de la ciudadanía lleva a la consideración de que diferentes contextos producen diferentes valores y prácticas sociales capaces de formular y proponer otras ideas de ciudadanía. El momento histórico-cultural después de la Segunda Guerra Mundial se construyó alrededor del concepto de relativismo como herramienta para evitar crímenes humanitarios. En el acercamiento multiculturalista, la centralidad está en la noción de identidad étnica, así como en la consideración de los derechos colectivos y no solamente individuales. Estas cuestiones evidencian las diferencias entre una ciudadanía formal y una ciudadanía substancial; es decir, entre el reconocimiento formal de pertenencia a un Estado-nación, expresado sobre todo mediante el derecho de voto, y otros derechos de participación en la esfera pública ejercitando derechos sociales, culturales, civiles ${ }^{3}$, etc. Ciudadanía multicultural significa también ciudadanía cuidadosa en proporcionar a los diversos componentes de una sociedad su propia voz en la arena pública y de decisiones.

Sin embargo, subrayar que cada cultura produce diferentes patrones sociales y culturales, dentro de los cuales se definen diferentes valores y practicas, significa también evidenciar la complejidad y la problematicidad del concepto de igualdad y de los principios universales que están en la base de la Declaración Universal de Derechos Humanos. Eso produce aquella paradoja entre tensión igualitaria y tensión en la diferencia, en la que la bandera del universalismo, paradójicamente, fue elevada en defensa de las diversidades. No obstante, la idea de "ciudadana cultural" es claramente una cuestión de pertenencia a una comunidad; en este sentido, las prácticas culturales son los ingredientes básicos de la ciudadanía y dan contenido al principio abstracto de igualdad (Jelin 2003).

2 Justo mientras estamos escribiendo estas páginas el gobierno brasileño está ratificando la ley de cuotas en las universidades federales reservando un porcentaje de puestos, que varia según la proporción de estas poblaciones en cada estado, para los estudiantes "negros, pardos e indígenas".

3 Véanse Holston James (2008) y Brubaker (1992), entre otros. 
Algunas de las exclusiones más importantes de la ciudadanía formal y de la ciudadanía substancial han sido las de las mujeres y las poblaciones indígenas y afrodescendientes, aunque esta afirmación requiere de precisiones históricas. Desde hace varios años, el estudio de la relación entre ciudadanía, mujeres y democracias se ha convertido en un tema para los estudios de género, para la teoría feminista y para la historia política. Propiedad y poder estaban en manos de los hombres y puede afirmarse que tanto el republicanismo como el liberalismo fueron discutidos sistemáticamente por diferentes corrientes feministas desde el momento mismo en que se declararon los "Derechos del hombre y del ciudadano" en 1789. El universalismo de la declaración tuvo aplicaciones concretas por diferentes gobiernos y muchas veces no se cumplió efectivamente. María Luisa Femenías (2007:52) sostiene que la Ilustración pregonó libertad, igualdad y fraternidad, y que esos lemas no se cumplieron no solo para la población europea, sino tampoco para la de los territorios coloniales cuyos pueblos eran considerados muchas veces como primitivos. Por otra parte, igualdad y diferencia fueron dos tópicos importantes de los cuestionamientos al modelo de ciudadanía universal que excluía a las mujeres. ${ }^{4}$

La cuestión de la desigualdad y la subordinación civil es particularmente sensible en la vida familiar, el matrimonio, las relaciones entre maridos y mujeres y en la potestad sobre los hijos. En la mayoría de los territorios, el establecimiento de un código civil afectó los destinos de los habitantes en cuestiones de familia, propiedad y libertades. A los códigos le siguieron leyes de matrimonio civil y registro civil de las personas como parte también de un proceso secularizador. Como es sabido, matrimonios, nacimientos y muertes estaban en manos de la Iglesia desde la época en que la Corona española había afirmado su dominio en el territorio americano y permaneció, cierto que no sin algunos cimbronazos, hasta que llegó la ola secularizadora hacia fines del siglo xix. Numerosos estudios en todos los países de América Latina han analizado extensamente la condición civil de las mujeres y se han publicado, además, colecciones donde los trabajos de síntesis ayudan a comprender un panorama complejo. ${ }^{5}$

Sólo para dar un ejemplo en un país como la Argentina, el código civil de 1869 consideraba el matrimonio como primordial para la familia y la sociedad,

4 En este punto la literatura es vastísima y su inclusión excede los marcos de este trabajo.

5 La literatura es demasiado extensa en la mayoría de los países de la región para ser citada. 
regulaba las relaciones entre los cónyuges dando forma a las responsabilidades de varones y mujeres pero otorgando la primaría a los primeros, se establecía la incapacidad relativa de la mujer casada y su minoridad en tanto que el marido ejercía la representación, las mujeres casadas no podían ser sujetos de contratos sin el permiso del esposo y tenían limitaciones para administrar los bienes propios o disponer de ellos. El poder para tomar decisiones, la autoridad sobre los hijos y el tema del patrimonio son tres elementos importantes de la sociedad conyugal. En todos los casos, la mujer quedaba sometida a una relativa incapacidad de hecho y el marido concentraba el poder legítimamente reconocido. Sin embargo, la rigidez del lenguaje del derecho no debería dar lugar a confusiones, pues la sociedad, incluso la familiar, es mucho más dinámica y compleja y en la vida cotidiana se producen diversas y conflictivas situaciones que hacen visibles las disonancias entre visiones cristalizadas y realidades.

La situación de la mujer en el plano civil fue objeto de debate en círculos universitarios, entre intelectuales y políticos y entre las propias mujeres que se adscribieron al movimiento feminista a principios del siglo $\mathrm{xx}$, y dio forma a numerosos reclamos y a presentaciones tanto en la cámara de diputados como en la de senadores. En 1902, 1909, 1914, 1915, 1919,1922 y 1924 se presentaron sucesivos proyectos de reforma con suerte desigual. En 1926 se sancionó una ley por la que se reconocían algunos derechos civiles para las mujeres. A juicio de algunos varones, como Enrique Rivarola, una figura destacada del pensamiento jurídico, político y social, "la mujer argentina se encuentra (...) en peores condiciones que el extranjero" (citado en Lobato 2008: 31). Estas condiciones se mantuvieron, cierto que con algunas modificaciones, hasta que, en 1968, se admitió la capacidad plena de la mujer, cualquiera fuera su estado civil; en 1985 se modificó el régimen de patria potestad, estableciendo la patria potestad compartida de los hijos menores por parte de los padres y de las madres, y en 1987 se estableció el divorcio vincular y se derogó la obligación de llevar el apellido del marido. Con la reforma constitucional de 1994 se incorporó, con jerarquía constitucional, la "Convención sobre la eliminación de todas las formas de discriminación contra la mujer".

Por otra parte, la multiplicación de actores políticos y la aparición de una política de las minorías en los últimos decenios del siglo xx y en particular en las revoluciones neoliberales en América Latina, han puesto en primer plano el concepto de sociedad civil para señalar aquellos actores no estatales organizados en la esfera pública. En este contexto, el término governance define el conjunto de prácticas de gobierno que tienden a integrar los aspectos de la soberanía directa del Estado-nación con la acción de otros organismos pú- 
blicos, privados y civiles. ${ }^{6}$ En ese contexto, en América Latina, entre los años ochenta y noventa del siglo xx, emerge la atención internacional hacia la cuestión indígena. La Declaración de los Derechos de los Pueblos Indígenas, aprobada en septiembre de 2007 por las Naciones Unidas, es solamente el último capítulo del largo proceso a través del cual estos pueblos han sido reconocidos como "personas jurídicas". Sin embargo, la visibilidad internacional y jurídica todavía no ha proporcionado, en varios de los casos, el acceso a una ciudadanía substancial, así como el cumplimento social, político y cultural de las normas nacionales e internacionales.

Lo cierto es que, en los últimos decenios, varios países de América Latina han introducido profundos cambios en la relación con las comunidades indígenas dentro de su territorio (rural y urbano). En particular, la presencia de grupos cada vez más organizados y políticamente influyentes ha permitido, en algunos casos, el reconocimiento constitucional de derechos estrechamente vinculados con las identidades indígenas. Cuando se habla de la construcción de una ciudadanía indígena en América Latina, se considera básicamente cuestiones que se mueven entre el reconocimiento de los derechos civiles más importantes y la aplicación de derechos específicos relacionados con el contexto étnico. Este debate sobre el reconocimiento -no sólo de los derechosopera a través de un proceso de politización de la identidad. El concepto de ciudadanía, y de ciudadanías diferenciadas, ha sido y es una de las herramientas más influyentes y uno de los contenidos más cruciales de las demandas de los movimientos étnicos en América Latina. Asimismo, la referencia a la ciudadanía ha proporcionado un background y un principio común para una vasta diversidad de movimientos sociales que se reconocen en la lucha contra la exclusión social y económica, así como la ampliación de las arenas políticas (Dagnino 2003). Las nuevas prácticas indígenas de ciudadanía se basan no sólo en el reconocimiento mutuo y la participación en el desarrollo político, económico, social y cultural de los diferentes actores, sino también en la construcción de una nueva identidad, identificada también a partir de la relación con la cultura dominante.

La construcción de una ciudadanía social en la región latinoamericana constituye otro vasto campo problemático. La educación, la salud, el derecho al trabajo, el derecho al bienestar cuya adquisición y reconocimiento son parte importante de lo que se ha denominado ciudadanía social. Ella está estrechamente relacionada con nociones como las de igualdad, solidaridad y

6 Véanse Larner/Walters (2004) y Yashar (2005). 
no discriminación. Buena parte del proceso de reconocimiento de los derechos que conforman la ciudadanía social han estado articulados alrededor del mundo laboral. Por eso, la literatura más abundante analiza el movimiento de organización, demandas y reacción del Estado, más la intervención de fuerzas políticas e ideológicas así como de intelectuales y políticos que impulsaron la instauración de una sociedad laboral más justa. ${ }^{7}$ A lo largo de todo el siglo xx puede rastrearse el camino que siguió el establecimiento de leyes sociales que muchas veces fueron incumplidas dando lugar también a la conformación de una fuerza de trabajo "clandestina" y desposeída de derechos.

Es interesante destacar que buena parte de esa legislación amparaba a los trabajadores urbanos y que la población rural quedaba a merced de los grandes propietarios rurales o agroindustriales o condenada a subsistir. Incluso dentro de un mismo territorio podían darse asincronías notables. Sólo para dar un ejemplo, en Argentina, en 1905, se sancionó la ley de descanso dominical; en 1907, la que protegía el trabajo femenino e infantil; en 1915, la de accidentes de trabajo y entre 1915 y 1945 se dieron otras leyes nacionales y provinciales sobre sueldos y salarios, sistemas de pensiones y jubilaciones, así como se fue extendiendo la negociación colectiva de condiciones de trabajo, pero fue recién en 1944, con la sanción del Estatuto del Peón Rural, cuando se reconoció el derecho de los trabajadores rurales a gozar de condiciones dignas de trabajo, de salarios mínimos, de descanso dominical, de vacaciones pagadas, de estabilidad de adecuadas condiciones de higiene y alojamiento. En Brasil fue sobre todo en la década de 1930 cuando los trabajadores urbanos tuvieron algunas leyes sociales que habían sido reunidas en la Consolidación de las Leyes de Trabajo en 1943, pero esos derechos recién se extendieron en 1963 a los trabajadores rurales con el Estatuto del Trabajador Rural. Además, para el caso de Brasil hay que prestar particular atención al tema de la esclavitud y a la pervivencia de sistemas de trabajo existentes en el Nordeste o en la región cafetalera, donde se sojuzgaba a los trabajadores, aunque la esclavitud había sido formalmente abolida. Se podría decir que el proceso de construcción de la ciudadanía social ha sufrido un serio cimbronazo con la aplicación de políticas neoliberales en la región a fines del siglo xx. Ese movimiento no es uniforme y en algunos países se están produciendo correcciones, que aunque limitadas, buscan reducir la incertidumbre y vulnerabilidad de amplias capas de la población. Hoy también asistimos a una Europa convulsionada, ya que el escenario global es complejo, pero lo cierto es que, en todos los países,

7 La bibliografia es tan extensa que no puede ser incluida en este texto. 
las crisis del Estado "benefactor", "providencia", "social” o como se llame ha puesto en evidencia las dificultades para garantizar empleo y bienestar y ello genera descohesión y exclusión social para amplias franjas de la población. El debate permanece abierto.

Este libro no pretende abarcar todas las dimensiones, ni todos los períodos históricos, más bien busca mostrar algunos interrogantes y las preocupaciones alrededor de viejos y nuevos temas que vertebran la cuestión de la ciudadanía en el pasado y en el presente. Al margen quedan varios desafios actuales que hacen más complejo el panorama de las formas de ciudadanía. Sólo como ejemplo planteamos el tema de la "ciudadanía digital" o de la "e-ciudadanía", visible en la cantidad de movimientos políticos o de grupos juveniles que se convierten en ciberactivistas. El Foro Social Mundial y organizaciones como Greenpeace proponen, por ese medio, acciones locales y globales, y Amnistía Internacional ofrece espacios de denuncias para violaciones a los derechos humanos.

Sin embargo, esta nueva forma de ejercicio ciudadano tiene también sus límites. Uno de los más importantes es el de la "brecha digital", sin duda en América Latina y el Caribe, pero no sólo en esta región. La noción de brecha digital se refiere a la distancia que separa al grupo de población que puede acceder a las tecnologías de la información y de la comunicación (TIC) de los que no cuentan con esas posibilidades. Esto significa que se producen segmentaciones en la población de acuerdo al nivel socioeconómico, al género, a la etnia o a la edad.Y, como se ha visto en los procesos políticos del Norte de África recientemente, y en algunas otras ciudades europeas y americanas, la Red es una nueva forma de participación ciudadana. Cabe preguntarse entonces sobre el tipo de democracia participativa que puede resultar cuando se analizan los indicadores de segmentación en diferentes países.

Otro tema importante que permite la reflexión sobre nuevas formas de ciudadanía es el del medio ambiente. El cuidado del "medio ambiente" ha dado paso a un nuevo término "ciudadanía ambiental" y al ejercicio de acciones prácticas concretas localizadas territorialmente. La práctica política relacionada con el cuidado del medio ambiente abarca un abanico de situaciones presentes en América Latina: la amenaza a los estilos de vida de las comunidades campesinas e indígenas por algunos emprendimientos económicos, el peligro que implican para la población algunos desarrollos mineros o industriales, las campañas de preservación de la fauna en vía de extinción o del sufrimiento de algunos animales, el cuidado del medio ambiente ante múltiples amenazas. No queda al margen de la configuración de esta nueva 
forma de ciudadanía la separación existente en muchos países entre zonas con mejores condiciones ambientales, donde viven las personas de más y mejores recursos económicos, y otras de visible degradación ambiental donde viven los más pobres o los grupos excluidos. En este punto se juntan los límites de la ciudadanía social y los alcances de la ciudadanía ambiental. De modo que esta forma de ciudadanía constituye un campo de acción política y también una nueva área de reflexión, aunque muchos de los trabajos pioneros aparecieron en la década de 1960 (Alimonda 2003, Brailovsky 1999, Dobson 2001, entre otros). Las investigaciones más recientes enfatizan la consolidación de un modelo "extractivista" en América Latina que tiende a la monoproducción, el surgimiento de una enorme gama de conflictos socioambientales y la emergencia de un pensamiento ambiental latinoamericano. ${ }^{8}$

En este libro se analizan entonces un conjunto de formas de ciudadanía y quedan al margen otras, fundamentalmente por razones de espacio. En la primera parte son tres las cuestiones que se encuentran bajo examen organizadas bajo la lente de la política: sufragio, representación y derechos sociales, las cuestiones de género y la dimensión étnica vertebran los elementos diferenciadores. Se analizan problemas comunes para una América Latina heterogénea o se focaliza en un caso particular como un modo de introducir un problema más general que puede seguirse en otras experiencias históricas. Ninguno de los autores pretende cerrar los problemas, sino más bien dejarlos abiertos a nuevas exploraciones, interrogantes, debates. El estado de la investigación en y sobre América Latina favorece para algunos temas una mirada más abarcadora y de largo plazo; en otros casos, en cambio, el análisis sobre una cuestión específica, localizada en un territorio recortado, permite pensar las transformaciones históricas sin perder de vista la perspectiva global.

En este sentido, la contribución de Flavia Macias es una expresión de la variedad de problemas y situaciones que la historia política del siglo XIX americano aborda. Podría decirse que la agenda de investigación es amplia en las dimensiones consideradas, pero centrada en la configuración del republicanismo y en la construcción ciudadana. El texto nos permite recorrer el análisis de la dimensión política de la ciudadanía del siglo XIX alrededor de

8 Véanse los textos publicados en OSAL, Observatorio Social de América Latina, año XIII, $n^{\circ} 32$, noviembre de 2012, dedicado a los movimientos socioambientales, en particular los de Svampa y Acselrad. 
tres elementos clave de su articulación en un momento histórico marcado por el proceso independentista y la guerra, así como por los experimentos institucionales cambiantes y conflictivos de los Estados nacionales emergentes. Apoyándose en los nuevos estudios, se plantean las formas que el voto, la opinión y las armas permiten comprender el modo en que los actores del siglo XIX concibieron al "ciudadano". Pero, de acuerdo con la idea central que recorre este libro sobre procesos abiertos, inacabados y reconfigurados de contenidos simbólicos, políticos y culturales de construcción ciudadana y de análisis y perspectivas sobre las que se basan, queda abierta la posibilidad de incorporar la dimensión de la justicia y el derecho al estudio de la ciudadanía política.

Verónica Giordano aborda, como ella misma lo expresa, la tríada democracia, ciudadanía y sufragio en Argentina, Brasil, Chile y Uruguay desde el diálogo establecido entre la sociología histórica y los estudios de género, y plantea un problema: el de la circulación de las ideas en el contexto de la modernidad en América Latina. Habría que agregar, aunque ella no lo dice, que los conocimientos son trashumantes y que crean "puentes entre comunidades diferentes" y, en este sentido, las teorías feministas y de género han impulsado una ampliación del horizonte cognitivo en muchas disciplinas. En el capítulo se enfatiza que el debate sobre el sufragio universal inclusivo de las mujeres en los países bajo estudio fue contemporáneo a los sucesos europeos que desde la Revolución Francesa condujeron a la universalización del sufragio ejercido por los varones. De ese modo se produjeron "olas" de discusiones relacionadas a su vez con los particulares contextos políticos en cada uno de los países estudiados. La ola posterior a la Segunda Guerra Mundial aseguró el ejercicio del sufragio para las mujeres en muchos países en una y otra orilla del Océano Atlántico.

El análisis que se realiza muestra que la ciudadanía política se descompone en diversos elementos, como quién es el sujeto de ese derecho (de género), si es un derecho o una obligación o ambas cosas, si está relacionado con el nivel municipal, provincial/estadual/departamental o nacional y si se realiza dentro de un marco republicano centralista o federalista. Quedan abiertos otros entrecruzamientos posibles como el de los niveles de alfabetización, la etnia/ raza y la pertenencia de clase de los sujetos de la ciudadanía política. El texto de Giordano, en diálogo con el de Macias, muestra también los límites de una vasta literatura articulada alrededor de la ciudadanía política en América Latina, que al centrarse en el ciudadano universal masculino dialoga poco con otra vasta literatura sobre el género de la política y viceversa. 
Los capítulos escritos por María Elba Argeri y Juan Suriano se centran en el estudio de la cuestión de la ciudadanización del "indio bárbaro" y de las dimensiones sociales de la ciudadanía en Argentina. Argeri analiza la compleja relación de las poblaciones indígenas con principios como los de ciudadanía y justicia, considerados relevantes para los nuevos Estados republicanos. Muestra que la ciudadanía estaba definida por la residencia en diferentes jurisdicciones territoriales, la provincia o la nación, y que los contextos políticos, ya sea el Estado liberal republicano o los populismos, en particular el peronismo, buscaron conformar una ciudadanía basada en la igualdad ante la ley y como parte de las políticas de expansión de la idea de bienestar y de justicia social. Destaca también que la política de derechos humanos que siguió a la última dictadura militar argentina impulsó también una redefinición de los alcances de la ciudadanía. Juan Suriano examina la construcción de la ciudadanía social como un proceso multifacético y de ninguna manera lineal. El proceso histórico argentino, más allá de sus asincronías, de sus momentos donde los debates y las demandas se activaban, constituye una clara advertencia sobre las consecuencias de las limitaciones, recortes y conculcaciones de los derechos sociales no sólo para la población, sino para la estabilidad política en la región.

La complejidad de las configuraciones de la ciudadanía es más palpable aún cuando se incorporan los debates actuales. El artículo de Jeanine Anderson y Helen Palma Pinedo aunque está focalizado en la condición ciudadana de niños y niñas en Perú, al plantear las tensiones entre protección e indefensión, tutelaje y explotación, impulsa una reflexión más amplia, susceptible de ser examinada en otros países en el contexto de la formulación de políticas de inclusión social de los gobiernos latinoamericanos. Importa aquí la dimensión generacional de la ciudadanía, una deuda social de los gobiernos de la región, más allá de las declaraciones que realizan gobernantes y funcionarios, y también independientemente de las aspiraciones de cada uno de nosotros. El desafio es pensar cuáles serían los bordes de una ciudadanía multigeneracional e intercultural.

Sofia Venturoli y Francesco Zanotelli vuelven sobre las tensiones entre las nociones de igualdad, un componente importante en la idea de ciudadanía, y las específicas instancias étnicas de las poblaciones indígenas en América Latina. En diálogo con el texto de Argeri, advierten una vez más sobre la ambigüedad de las categorías étnicas, aunque no sólo de ellas. El desafio actual parece ser el del camino posible a transitar para hacer, de un concepto diseñado en el siglo xix en Europa, cuyos rasgos distintivos son la blancura y la masculinidad, otro más abierto, mudable, permeable. En suma, ciudadanías 
con confines menos nítidos y basadas en nociones de equidad y no necesariamente localizadas en el mapa del Estado-nación. Sin embargo, las fronteras no han sido borradas y son los dilemas políticos, culturales y sociales de los agentes en cada uno de los Estados latinoamericanos los que ponen a prueba, una y otra vez, ideas y prácticas en el ejercicio de las diferentes formas de ciudadanía.

Finalmente, el capítulo de Marianne Wiesebron parte de una cita que abre un interrogante. ¿El significado de la democracia es algo más que la participación electoral? ¿Cómo deberían funcionar las democracias? ¿Es posible elegir entre democracias representativas o deliberativas? ¿Cuál es el lugar del Parlamento? ¿Qué rol le cabe a los ciudadanos? Wiesebron responde algunas de estas preguntas a partir del análisis de la "democracia participativa". La experiencia en Rio Grande do Sul, capital del estado de Porto Alegre, en Brasil, opera en el texto para plantear problemas más vastos. El punto nodal, no obstante, se relaciona con la legitimidad política y con el diálogo entre ciudadanos y políticos que en muchos país americanos se interrumpe en más de una oportunidad. El análisis del nivel municipal se convierte en una esperanza para romper el círculo vicioso de la participación política tradicional, eliminar o atenuar las prácticas corruptas y mejorar en suma la situación de la población, en especial de los que menos tienen.

Diferentes teorías y prácticas disciplinares; tiempos largos y cortos en los procesos de construcción de la ciudadanía en países de América Latina y disímiles experiencias académicas y generacionales de los autores se entrecruzan en este libro buscando recuperar la complejidad de la configuración de ideas y prácticas en las que están involucrados los ciudadanos, pero también queda visible el modo en que las teorías influyen en las perspectivas de análisis. Interpretaciones y reinterpretaciones que tienen el rasgo de trashumantes e inacabadas. 
I. PERSPECTIVAS HISTÓRICAS 


\title{
LA CIUDADANÍAY SU DIMENSIÓN POLÍTICA EN LA AMÉRICA LATINA DECIMONÓNICA
}

\author{
Flavia Macías
}

En el siglo XIX, la pregunta por la ciudadanía surgió en un contexto de profunda crisis y de rápidos cambios. Desatados los procesos revolucionarios e independentistas, la incorporación de los principios de soberanía del pueblo y de gobierno representativo, y con ello la adopción de formas republicanas de gobierno (con la sola excepción de Brasil) implicó para los contemporáneos un gran desafio: la configuración de nuevas comunidades políticas edificadas sobre bases esencialmente diferentes de las experimentadas en tiempos coloniales. Esta tarea planteó otro reto: la invención de un nuevo sujeto político, el ciudadano, considerado como el legítimo depositario de la soberanía. Si bien se mantuvieron por algún tiempo referentes del Antiguo Régimen para resolver de forma más rápida los desafios de la representación y de la legitimidad políticas (mandato imperativo, cabildos abiertos, el concepto de vecino), la ciudadanía se fue definiendo a través de normativas y prácticas electorales nuevas, de instituciones de producción de opinión (asociaciones, prensa) y de novedosos modos de construir, sostener, reproducir e impugnar el poder. Todo esto hizo de las repúblicas latinoamericanas experiencias inéditas que se constituyeron en verdaderos laboratorios políticos (Sabato 2006). La militarización de la sociedad, heredada de las revoluciones y de la guerra por la independencia, complejizó este convulsionado escenario. La construcción ciudadana se adaptó a la demanda de nuevos actores que, surgidos del escenario bélico revolucionario, se sintieron protagonistas del proceso político en 
ciernes: plebe urbana, ejércitos residuales, milicias, comandantes. Ellos buscaron insertarse en los nuevos espacios de poder mediante las vías formales que se estaban diseñando, pero también a través de prácticas informales (motines, pronunciamientos, asambleas cívico-militares) que terminaron por incorporarse a la vida pública. En ese contexto, las milicias proyectaron su existencia más allá de las décadas revolucionarias, aglutinaron a la ciudadanía en armas y se constituyeron en un tipo de organización militar compleja y alternativa a los ejércitos regulares con aspiraciones profesionales. Más tarde, la Guardia Nacional, organizada en las diferentes naciones latinoamericanas, retomó y canalizó la tradición miliciana y la herencia político-militar revolucionaria, estableció los atributos del ciudadano en armas e institucionalizó la dimensión militar de la ciudadanía política.

Me propongo abordar aquí las nuevas miradas y conclusiones que, sobre el siglo XIX latinoamericano, ha proporcionado la renovada historiografia de las últimas décadas. Concentraré el análisis en el proceso de construcción de la ciudadanía política que, a la luz de los nuevos estudios, evidenció tres componentes centrales: el voto, la opinión y las armas. A partir de aquí, se intentará comprender de qué manera concibieron los contemporáneos al ciudadano y bajo qué parámetros definieron su radio de acción en la vida pública.

\section{EL CIUDADANO ELECTOR}

Desde hace ya varias décadas, las elecciones y la definición del votante se constituyeron en cuestiones que llamaron la atención de la historiografía dedicada al siglo XIX. Los nuevos abordajes se preocuparon, en primer lugar, por destronar aquellos presupuestos que subestimaban las experiencias electorales latinoamericanas decimonónicas, por considerarlas ajenas a la voluntad popular, carentes de competencia partidaria y teñidas por prácticas fraudulentas. A su vez, postularon la especificidad de los procesos eleccionarios latinoamericanos y la adaptación de los principios del liberalismo y de la república a cada caso nacional (Annino 1995; Malamud 2000). A partir de aquí, los análisis políticos sobre las elecciones en América Latina arrojaron interesantes y llamativos resultados. En primer lugar, la definición del ciudadano elector gozó, para toda América Latina, de una relativa amplitud. Fueron la edad (entre 17 y 25 años), el sexo (masculino) y la residencia, más que la propiedad y la capacidad, las variables que, en general, lo definieron. La dependencia, relacionada con la falta de autonomía, fue una barrera que inicialmente se incorporó en algunos casos 
puntuales, pero que con el tiempo desapareció. En un principio, varias de las regiones del ex imperio hispánico echaron mano del concepto de vecino para definir al ciudadano. El caso de México es, en este sentido, particularmente llamativo, ya que allí la vecindad fundó a la ciudadanía y esta transacción entre tradición y modernidad se proyectó por todo el siglo XIX. Por lo tanto, la ciudadanía asumió contenidos sociales y territoriales tradicionales: para ser ciudadano había que demostrar un "modo honesto de vivir" y era el municipio el que conformaba el padrón electoral a partir de aquellos a los que en cada caso se consideraba vecino. Así, la flexibilidad de la noción de ciudadano-vecino mexicano varió de municipio en municipio, si bien el criterio que en general se observó fue amplio y aglutinante. En el caso de Argentina, la Constitución de 1853 permitió unificar las reglamentaciones electorales provinciales y garantizó la proyección durante todo el siglo XIX de una noción amplia del electorado que se definió por la nacionalidad, la edad y el sexo. Incluso más, algunos municipios de la provincia de Santa Fe admitieron el voto de los extranjeros. Ellos no participaban de las elecciones nacionales y provinciales, pero sí lo hicieron en comicios municipales (Bonaudo 2003; Sabato/Lettieri 2003; Ternavasio/Sabato/De Privitellio/Persello 2011). Estas situaciones excepcionales que tuvieron al municipio como espacio de realización también se observan en Chile. Allí, las mujeres adquirieron derecho a voto en ciertos distritos, ingresando tempranamente al terreno de la ciudadanía política (Maza Valenzuela 2000).

Más allá de la amplitud con la que se concibió al electorado, los porcentajes de votantes en relación con la población masculina capacitada para hacerlo eran bastante bajos en la mayor parte de América Latina (entre un 5 y un 20\%). El número era fluctuante, variaba de elección en elección y se vinculaba con cada coyuntura. Es por esto que las dirigencias, además de ocuparse -con éxito- de la regularidad de las elecciones, implementaron diferentes estrategias para garantizar la asistencia del electorado el día de los comicios. Esto implicó fuertes movilizaciones clientelares, importantes negociaciones particulares e incluso variadas dosis de violencia que pusieron en evidencia la fuerte competitividad electoral. Clubes, prensa, amistades y una abultada clientela eran los responsables del éxito de una candidatura y de una elección. La no reglamentación de la competencia, de la selección del candidato y de la situación en la que quedaba el perdedor fueron variantes que incorporaron un alto grado de incertidumbre a los comicios, constituyéndose muchas veces la jornada electoral en un verdadero combate.

Los partidos ocuparon aquí un lugar central y su organización y funcionamiento demuestran que la participación electoral era entendida como un acto 
colectivo. Los mismos aglutinaban a un complejo y variado universo social articulado en redes clientelares. El valor de los partidos decimonónicos -diferentes en su estructura de los partidos modernos- radicó en su capacidad para negociar listas, organizar la campaña, difundir ideas mediante periódicos - muchas veces fundados con estricto sentido electoral- y organizar y movilizar a los votantes como fuerzas electorales. Es aquí donde los liderazgos intermedios ocuparon un importante rol.Sin embargo, en el marco de un universo político pautado por el principio de unanimidad, la idea de "partido" se tornó bastante problemática. La tensión entre la aspiración a representar al pueblo como totalidad y la necesidad de organizarse para ganar estaba contenida en esa figura del partido. Por lo tanto, los partidos convocaban al "pueblo" en su más amplia definición, pero movilizaban a un conjunto reducido de personas. Apelaban al espíritu cívico de la población, pero recurrían a los militantes organizados colectivamente como fuerzas electorales. Invocaban al ciudadano libre y autónomo, pero construían sus clientelas apoyados en lazos de subordinación personal y grupal (Sabato 2006). A todo esto se suma la idea de "facción", que circulaba permanentemente en el vocabulario de la época. Ésta era la forma en la que un partido descalificaba a su adversario y le adjudicaba connotaciones fuertemente negativas vinculadas con la obstrucción del orden y del funcionamiento republicano.

Si bien las candidaturas surgidas de cada partido eran detentadas por miembros de la élite política, los votantes provenían de los más diversos grupos sociales y etnias (Geler 2007). Instancias informales de participación como asambleas, motines y movilizaciones desarrolladas desde tiempos de las revoluciones de independencia habían otorgado a artesanos, jornaleros, empleados -entre otros- un primer acercamiento al emergente escenario republicano. Si bien el acto de votar no fue en general ejercido de manera espontánea, constituyó una práctica de la que la mayoría de los sectores sociales participó y que la dirigencia se encargó de mantener vigente y activa.

Sin lugar a dudas, las elecciones movilizaban a mucha gente, incluso a aquellos excluidos de la ciudadanía. Mujeres, niños o extranjeros fueron muchas veces movilizados por líderes locales para que, mediante su asistencia a rituales y movilizaciones callejeras, presionaran en beneficio de uno u otro candidato. En el marco de sistemas que con el tiempo incorporaron restricciones, como es el caso de Bolivia, la "ilegal" participación electoral de campesinos, indígenas, artesanos (entre otros) llamó la atención de la actual historiografia. En particular, los trabajos de Marta Irurozqui analizan a la "infracción" electoral como instancia de construcción, aprendizaje y conquista ciudadana. Aquellos empeñados en reincorporarse al universo de la ciudadanía se inte- 
graron a sistemas de lealtades y redes clientelares y a partir de allí participaron transgrediendo normas o aprovechando sus ambigüedades o intersticios para negociar beneficios y exaltar su valor político (Irurozqui 2000).

Como ya referimos en párrafos anteriores, el desorden y la violencia eran frecuentes y fueron estas situaciones las que llevaron a que muchos miembros de la dirigencia impugnaran desde el Parlamento y la prensa este tipo de comportamientos en los comicios. Las fuertes movilizaciones electorales comenzaron a ser objeto de temor y élites como las de Bolivia, Perú, Chile y Brasil experimentaran entre mediados y fines del siglo XIX un giro conservador materializado en el recorte del universo de los votantes mediante la imposición de los requisitos de propiedad y capacidad para poder sufragar (Mc Evoy 1997; De Carvalho 1985; Valenzuela 1985; Irurozqui 2005). Esto no siempre implicó la disminución drástica del electorado. En el caso de Perú, por ejemplo, los estudios demuestran que la verdadera contracción se produjo recién en 1896, cuando se exigió la alfabetización del votante y no cuando, en 1861, se implementó el requisito de la propiedad. Por su parte, en casos como los de Argentina y México, las reacciones frente a las tumultuosas elecciones fueron un tanto diferentes. En la Argentina de 1880 se impuso un andamiaje institucional y político materializado en la figura de "gobiernos electores" y en un sistema de partido único (el PAN) que permitió a las dirigencias un mayor control sobre la selección de candidatos y el desarrollo de las elecciones (Botana 1994; Alonso 2010). Igualmente, esta salida no garantizó la anulación del disenso ni de las revoluciones, que siguieron instrumentándose como herramientas de acción ciudadana y de cuestionamiento al propio sistema recientemente implementado. En México, las dirigencias intentaron controlar las movilizaciones electorales mediante la incorporación, desde muy temprano, de sistemas de votación indirecta de hasta tres grados. La capacidad y la propiedad se erigieron en requisitos para votar en las instancias más altas y, a su vez, para ser elegible. De esta manera, la comunidad política mexicana se jerarquizó y los candidatos o los electores de ciertos grados no podían ser todos los ciudadanos en su más amplia definición, sino "los mejores, es decir los más aptos para representar a la comunidad política”. ${ }^{1}$

En toda Latinoamérica, la configuración de comunidades políticas sostenidas sobre la base del principio de soberanía del pueblo y compuestas, por lo tanto, por ciudadanos "libres e iguales entre sí” incluyó también jerarqui-

1 Sobre este concepto en particular y sobre la configuración ciudadana en general, en México, en la segunda mitad del siglo xix, véase el artículo de Alicia Hernández Chávez y Marcello Carmagnani incluido en Sabato 1999. 
zaciones que no reproducían necesariamente las desarrolladas a nivel social pero que sí significaban diferencias entre electores y elegibles. Según Elías Palti, esto marcó uno de los grandes y complejos desafíos para las dirigencias latinoamericanas decimonónicas:"como producir esa partición de la sociedad que recorte gobernantes de gobernados sin quebrar ese sustrato igualitario que ahora formaba su base" (Palti 2010: 70). ${ }^{2}$ Las diferencias políticas constituidas en las repúblicas decimonónicas, que se profundizaron a fines del siglo XIX mediante la incorporación, en algunos casos, del voto restrictivo o en otros, de nuevos sistemas institucionales de control electoral, comenzaron ser puestos en cuestión de forma decisiva. Estas impugnaciones fueron lideradas por actores políticos que adquirieron una fuerte presencia en el escenario de fin de siglo: partidos modernos (partido socialista, anarquismo; UCR en la Argentina), sindicatos y asociaciones civiles. El advenimiento de la democracia de masas marcó la emergencia de una nueva era política con una nueva concepción de la representación que se materializó en importantes reformas electorales como la chilena o la argentina de principios de siglo xx. A partir de este nuevo clima de ideas y de estas experiencias, muchas naciones latinoamericanas ampliaron y garantizaron la representación partidaria en los órganos de gobierno incorporándose también el voto universal masculino y secreto.

\section{EL CIUDADANO Y LA OPINIÓN}

La configuración de la ciudadanía política decimonónica y su relación con el desarrollo de la sociedad civil constituye una temática de estudio creciente durante los últimos años. Más allá de las variantes y ritmos regionales, existen hoy consensos en torno al valor político y social de los ámbitos formales e informales de sociabilidad y de la prensa periódica en la construcción de las comunidades políticas decimonónicas. En particular, se destaca su rol en el aprendizaje ciudadano, en la internalización de prácticas y valores igualitarios y en la construcción de la opinión. Esta última constituye una dimensión propia de la vida republicana y un canal comunicante fundamental entre pueblo y política que demostró un particular impulso en la segunda mitad del siglo XIX. A partir de las revoluciones de independencia, la opinión del público se invocó como instancia legitimadora del poder y de las acciones de gobierno.

2 Este tema ha sido tratado para el caso francés en Rosanvallon (1998). 
Un gobierno se constituía a partir del voto, pero debía someterse también a la supervisión y juicio de los gobernados.

La tradición asociativa se remonta al siglo XVIII europeo y a la luz de las revoluciones de independencia experimentó un particular desarrollo en América (Guerra/Lamperiére 1998). En las primeras décadas de vida independiente, la sociabilidad se circunscribió, por lo general, a los grupos de la élite y se concentró en espacios como tertulias, círculos literarios, salones, cafés y logias. A través del estudio de los cafés, por ejemplo, puede visualizarse la transmutación de un ámbito de reunión, intercambio y juego de la llamada "gente decente" en un espacio de opinión permeado por las nuevas ideas políticas. Investigaciones desarrolladas para el Río de la Plata demuestran que estos espacios, si bien albergaban a gente de élite, también aglutinaban a grupos más diversos que incluían a jóvenes y comerciantes de la ciudad que se reunían allí a hacer sus negocios (González Bernaldo 2000). A su vez, se generaron allí verdaderas tribunas, redes y asociaciones políticas, surgieron personajes que se vincularon con las ideas más radicales de la revolución, se idearon alzamientos y se fundaron periódicos. Por su parte, las logias o sociedades secretas han cautivado la atención de los historiadores por haberse constituido en reuniones fuertemente politizadas. Muchas de ellas proliferaron tempranamente en aquellas latitudes del imperio hispánico que tomaron la decisión de desvincularse del proceso juntista español. Allí se desarrollaron debates en torno a la declaración de la independencia y a las formas republicanas de gobierno.

Sin embargo, el fervor asociativo floreció a partir de mediados del siglo XIX. Las asociaciones proliferaron en importantes ciudades latinoamericanas y se vincularon con la modernización y afincamiento de la sociedad civil y de la esfera pública (Aghulon/Bravo Lira 1992; Del Águila 1997; Forment 2003; Lettieri 2006). Este tipo de sociedades eran impulsadas desde la élite, ya que se consideraban espacios de educación cívica y de aprendizaje de las virtudes ciudadanas. Es por esto que, a través de las mismas, además de los intercambios orales, se promovió la circulación de escritos vinculados con los principios de la Ilustración, la república y el liberalismo (Guerra 2002). Había asociaciones de todo tipo: sociedades de ayuda mutua, literarias, culturales, científicas, de tiro, de bomberos voluntarios, de obreros. Las mismas se afianzaron junto con la institucionalización de las libertades de prensa, asociación y reunión que, en diferentes momentos, se fue concretando en las distintas naciones latinoamericanas. En general, incluían a más de un grupo social aunque algunas eran fuertemente exclusivas, como la Sociedad de Beneficencia. La organización interna era pautada mediante reglamentos y estatutos, se privilegiaban formas 
democráticas de gobierno y de elección de comisiones directivas. Proveían a sus socios de redes económicas y sociales a la vez que estrechaban lazos de pertenencia y solidaridad. Pero, sobre todo, conectaban con la vida pública y las prácticas ciudadanas a un sinnúmero de personas contenidas o no en los márgenes de la ciudadanía política (mujeres y extranjeros, por ejemplo). En ocasión de la revolución de 1880 en Buenos Aires las asociaciones de inmigrantes apoyaron las iniciativas de los grupos autonomistas y nacionalistas liderados por Carlos Tejedor, formándose incluso para el combate batallones de extranjeros. El diario L'Operario Italiano sostenía que, si bien nunca habían alentado a sus connacionales a tomar las armas, se trataba ahora de la defensa de Buenos Aires y que "la defensa es un derecho anterior a cualquier derecho político $[. .$.$] el derecho a la existencia es un derecho natural y por lo tanto$ superior a cualquier derecho adquirido" (Sabato 2008: 198).

A la vida asociativa señalada se sumaron otros ámbitos de sociabilidad populares (pulperías, plazas, calles, asambleas cívico-militares) que incorporaron a otros sectores a los avatares de la vida pública. Estos espacios demostraron escasa autonomía de la política, se erigieron en instrumentos de las luchas partidarias, sirvieron para el afianzamiento de redes clientelares y expresaron "opiniones" de públicos muy variados (González Bernaldo 2000; Parolo 2008).

Los diarios se erigieron en una pieza clave del sistema político y también mostraron una particular proliferación en la segunda mitad del siglo XIX (Alonso 2004; Bonaudo 2005a; Navajas/Cucchi 2012). Muchos de ellos eran expresión coyuntural de un club que sólo duraba el tiempo de una elección. Su función era la de ejercer fuertes influencias en la opinión, movilizar electores y adherir voluntades. Otros, trascendieron esta característica y se constituyeron en espacios destinados al despliegue de discursos e ideas políticas, valores ciudadanos y republicanos y también en canales de publicidad de debates parlamentarios y de opiniones particulares. Un estudio para la provincia de Mendoza (Argentina) analiza la inauguración de un nuevo periódico local luego de 1862 llamado El Tupungato. El mismo fue lanzado por editores y políticos provenientes del exilio chileno e interpeló al grupo político en el poder mediante la publicación de una detallada agenda de las tareas que de ahora en más la "opinión pública" esperaba se resuelvan para refundar la república y sus instituciones: elaboración de una ley de municipalidades y de la reforma electoral, organización de la Guardia Nacional, especificación de las responsabilidades de los funcionarios, organización de una política impositiva, instrucción primaria, legalización de la libertad de imprenta, etc. Este 
diario también se expidió sobre las características del voto y condenó la relación entre milicias y electores en el marco de los comicios. Sean del origen que fuera, los periódicos de la segunda mitad del siglo xIX nunca dejaron de manifestar opinión sobre la vida pública en todos sus aspectos. Por lo tanto, su importancia en el desarrollo del juego político y en la construcción de la esfera pública fue fundamental.

Asociaciones, sociabilidades informales y prensa contribuyeron con la formación de diferentes públicos y opiniones que estrecharon vínculos entre la sociedad civil y la vida política fortaleciendo las instancias de configuración y afianzamiento de la esfera pública.

\section{EL CIUDADANO EN ARMAS}

La dimensión militar de la ciudadanía política en América Latina constituye uno de los campos de más reciente desarrollo por parte de la actual historiografia dedicada al siglo XIX. Las milicias, el ciudadano en armas y las revoluciones se han constituido en la lente privilegiada por los historiadores para el abordaje de la referida dimensión ciudadana, cuyo estudio ha permitido arribar a innovadoras conclusiones en torno a la relación entre violencia y política. Indudablemente, los cambios experimentados en los estudios sobre las milicias entendidas ya no como fuerzas informales y laxas sino como formas de organización militar alternativas en el marco del sistema político, han contribuido a proporcionar nuevas miradas sobre la dimensión militar de la ciudadanía y de la vida pública. El estudio de su morfología y funcionamiento desde una óptica política está proveyendo a la historiografia de nuevas conclusiones, por un lado, sobre su conflictiva convivencia con los cuerpos regulares y las diferentes concepciones de defensa a los que estas fuerzas remitían; por otro, sobre el rol del ciudadano en armas en la construcción republicana y el papel de la guerra y de las revoluciones en la configuración de un orden político. En este marco, ciudadanía armada, militarización y violencia son conceptos que se están integrando a las investigaciones históricas contemporáneas sobre el siglo XIX latinoamericano, desvinculados ya de su relación directa con la corrupción, la anarquía y los frenos al ingreso de la modernidad y asociados ahora con los procesos de institucionalización republicana y organización del Estado.

Las milicias eran fuerzas auxiliares del ejército, convocadas y movilizadas de manera eventual. Estaban integradas exclusivamente por ciudadanos que mediante su enrolamiento en las mismas se comprometían con la defensa de 
su patria. Por su estructura y funcionamiento, se diferenciaban del servicio regular-profesional y del posterior sistema de conscripción obligatoria implementado en el siglo xx. Su organización se remonta a los años de la colonia. Algunos estudios para el ex virreinato del Río de la Plata de la primera mitad del siglo XIX clarifican sus características, organización y funciones. En tiempos de la revolución de independencia funcionaron como cuerpos cívicosurbanos auxiliares de los ejércitos revolucionarios. La proyección de su organización local permitió a las autoridades de esa índole mantener su control en el enrolamiento y movilización. Sin embargo, su composición social se amplió e incluyó a gran cantidad de habitantes de las ciudades, muchos de ellos no portadores de las calidades vecinales exigidas en tiempos coloniales. Justamente, las variadas características de sus integrantes, el alto número de enrolados, sus funciones vinculadas con la defensa de la ciudad y sus instituciones, todo esto en combinación con la ya conocida faccionalización de los ejércitos revolucionarios, se constituyeron en razones que explican la íntima relación entre las milicias y la vida política revolucionaria. En calidad de milicianos o "cívicos", gran cantidad de habitantes protagonizaron los acontecimientos políticos desarrollados durante la revolución de independencia, entraron en contacto con el nuevo escenario y experimentaron nuevas formas de participación política (Di Meglio 2007; Macías/Parolo 2010). Los años de la revolución inauguraron la correspondencia (muchas veces fluctuante) entre el ciudadano elector y el miliciano, y entre los deberes y derechos ciudadanos y el servicio de armas (Cansanello 2003; Macías 2007).

La Guardia Nacional, organizada en las naciones latinoamericanas del siglo XIX retomó, afianzó y nacionalizó la tradición miliciana iniciada en las décadas de la guerra revolucionaria. En la Guardia Nacional debían enrolarse "todos los ciudadanos de la nación" ya que, en tanto tales, estaban comprometidos con la defensa de la Constitución y de las instituciones públicas (Chust/ Marchena 2007: 7-12). Su composición contrastaba con la de los ejércitos, integrados por soldados que muchas veces eran reclutados mediante el sistema de "enganche" o se encontraban allí cumpliendo una pena o castigo. De esta manera, a diferencia de la Guardia Nacional, no todos los enrolados en el ejército lo hacían en pleno goce de sus derechos civiles.

La amplitud del enrolamiento en la Guardia se correspondió con la amplitud del electorado. En relación con esto, se formalizó a través de esta institución la directa relación entre el ciudadano en armas y el votante ya que en general se planteó como requisito para poder votar el enrolamiento en la misma. Todo esto vinculó a la Guardia con la vida electoral, constituyéndose 
en espacio de politización social y de movilización de electores. Allí se formaron clientelas y partidos cuyos líderes intentaron controlar a los votantes mediante la monopolización de sus boletas de enrolamiento (Graham 1990).

Inicialmente, el estudio de esta institución militar fue abordado desde la óptica de la construcción de una identidad nacional asociada con la configuración del Estado direccionada de arriba hacia abajo. ${ }^{3} \mathrm{~A}$ la luz de las perspectivas utilizadas para el estudio de la Guardia Nacional francesa, expresión de la "nación en armas una e indivisible", estos estudios privilegiaron el análisis de rituales cívico militares, actos y discursos emanados desde el poder central. Los mismos tenían la función de promover en sus miembros el enrolamiento como un compromiso patriótico en el marco de una relación directa e identitaria con la nación. Nuevos avances han privilegiado la óptica local como forma de abordaje del estudio de la Guardia Nacional, ya que sus batallones, más allá de responder teóricamente al poder central, eran de organización provincial. La tensión provincia-nación en la construcción estatal ha comenzado a analizarse a través de la Guardia Nacional, institución militar que hizo evidente en muchas naciones latinoamericanas el conflicto y la puja entre autoridades locales (gobernadores, comandantes) y poder central por el control de la violencia. Todo esto tiñó el referente identitario fundante de la Guardia Nacional y promovió la asociación del ejercicio de las virtudes cívicas y de los derechos ciudadanos con la participación y la movilización políticas a través de las armas (Thomson 1990; Sabato 2008; Hernández Chávez 2007; Sobrevilla 2007; Macías 2011). ¿A qué tipo de identidades respondía entonces la Guardia? En Argentina, por ejemplo, los rituales, prácticas y discursos tendieron a identificar a la nación con la república y con la Constitución. A partir de aquí, el derecho de empuñar las armas por parte de la ciudadanía se reivindicó como un deber y también como un derecho frente a agentes internos o externos que pusiesen en peligro, justamente, la república y sus leyes. La revolución fue comprendida como un recurso que garantizaba la reinstauración del orden y, en ese sentido, constituía una práctica legítima. Si bien no dejaron de asociarse a conflictos políticos e interpartidarios, las revoluciones se incorporaron a la vida republicana como una práctica legítima y vinculada con los comportamientos ciudadanos. El derecho a revolución ha sido particularmente estudiado por Hilda Sábato, quien ha demostrado que esta práctica, cuya justificación apeló a viejas tradiciones coloniales reformuladas

3 Véanse los trabajos de J. Murilo de Carvalho y V. Peralta Ruiz incluidos en Sabato (1999). 
a la luz de las experiencias francesa y norteamericana, no estuvo reñida de la civilidad y se constituyó en parte indisociable de la experiencia republicana decimonónica, en permanente tensión y debate. Por su parte, los estudios que abordan la institucionalización de los "pronunciamientos militares" tanto en México como Centroamérica, sostienen que se trataba de formas de participación directa amparadas en el "sagrado derecho de insurrección" o de "resistencia" de los pueblos en el marco de los cuales los ciudadanos recuperaban su soberanía y, mediante las armas, podían deponer legítimamente a un gobierno que haya ultrajado el pacto de origen (Hernández Chávez 2005; Mejías 2004). Las movilizaciones armadas también están siendo estudiadas como ámbitos de participación y negociación popular utilizados en muchos casos por aquellos excluidos de la ciudadanía para manifestar demandas y negociar respuestas (Méndez 2005). Tal como la plantea Maurice Agulhon, la violencia se asoció con instituciones y prácticas que se constituyeron en instancias de transmisión de ideas y principios republicanos en los que los individuos y las armas adquirieron un vínculo esencial.

La guerra, como forma de violencia colectiva pero también como instrumento político, ha merecido nuevamente la atención de los historiadores. ${ }^{4}$ En algunos casos es analizada como instancia fundacional de la república y de generación de nuevos sistemas identitarios (Adelman 2011; Thibaud 2011; Hébrard 2002). A la luz de estas conclusiones la noción de patria ha sido revisitada teniéndose en cuenta la asociación de este concepto con referentes personales (comandantes, jefes militares) locales o grupales vinculados con las experiencias bélicas. Por otra parte, las miradas peyorativas en torno a la guerra y su función de obstructor de la configuración de un orden político están siendo revisadas. Nuevos trabajos la consideran como "sujeto rector de la práctica política" cuya implementación se ha legitimado en ciertas ambigüedades constitucionales o debilidades de los poderes en formación.

Los inicios del siglo xx fueron acompañados por el triunfo de la centralización política y la monopolización de la violencia por parte del Estado-nación, materializado todo esto en la conscripción obligatoria y en la nueva estructura de los ejércitos profesionales y modernos de las distintas naciones latinoamericanas. Esto implicó el ocaso de la tradición miliciana y, con ello, del principio de ciudadanía en armas, en un contexto de emergencia y afianzamiento de nuevos canales comunicantes entre ciudadanía, vida política y gobierno.

4 La obra pionera de Tulio Halperín Donghi (1972) ha estimulado gran cantidad de estudios sobre la relación entre la guerra, la desarticulación del espacio colonial y la formación de nuevos sistemas políticos. 
Nuevos abordajes PARA Un COMPLejo PROBlema

El plano de la justicia y, en especial del derecho, están constituyéndose en una fructífera línea de análisis cuyas investigaciones parten de una noción renovada, dinámica y flexible de la norma, entendida como un producto inacabado y muchas veces ambiguo, que se completa con las acciones e interpretaciones de los actores (Bonaudo 2005b; Caimari 2007; Palacio/Candioti 2007; Irurozqui/Galante 2011). La politización de la justicia, los usos de la ley y sus manipulaciones posibles por parte de diversos actores; la comprensión de la codificación estatal como un proyecto contradictorio, lleno de marchas y contramarchas que resaltan la contingencia y la multiplicad de proyectos estatales en disputa; la coexistencia de culturas legales que nos hablan de cómo los actores y los distintos colectivos sociales con sensibilidades jurídicas diferentes interpretan lo justo y lo injusto y utilizan a la norma y a las doctrinas jurídicas más allá de las formas esperadas son los parámetros a la luz de los que se están desarrollando nuevas interpretaciones sobre la justicia y los derechos ciudadanos, en las diferentes experiencias republicanas del siglo xIx latinoamericano.

Desde la óptica ciudadana, la implementación del sistema anglosajón de juicios por jurado constituyó una vía de acceso de los ciudadanos al ámbito de la justicia, en lo que refiere especialmente a delitos criminales. En la caso de Brasil, por ejemplo, el servicio de jury fue considerado por varios de los contemporáneos como un instrumento de educación cívica y de desarrollo del espíritu público. Para ser jury, los requisitos eran los mismos que para ser votantes de segundo grado, es decir, ingresos de 200 o 400 milreis según la ciudad, además de saber leer y escribir. Se estructuraba una lista de candidatos que se guardaba y se sorteaban de allí los integrantes del jurado que sesionaba dos veces por año unos quince días para la resolución de casos criminales. El número de personas capacitadas para ser jurados nunca fue muy alta dado, sobre todo, el requisito de saber leer y escribir. Sin embargo, resultaba algo menor que el número de electores resultantes luego de la reforma de 1881 (unos 79.302 jurados para todo el país). Los trabajos de José Murilo de Carvalho demuestran de qué manera esta institución fue para muchos intelectuales una vía de aprendizaje ciudadana, más allá de la corrupción vinculada a sus miembros y funcionamiento. Algunos aseguraban que esta corrupción no tenía que ver con deficiencias en la institución, sino con costumbres políticas que poco a poco irían puliéndose mediante la práctica y aprendizaje ciudadanos (Carvalho 1995). Para el caso argentino, la historiografia ha comenzado a interesarse en el abordaje de este tipo de instituciones. A los innovadores 
estudios sobre la justicia rural y el rol de los jueces como actores intermedios (Barriera 2010; Fradkin 2007) se suman nuevos abordajes sobre la constitución de jurados y el rol ciudadano en este marco. Los estudios demuestran que la implementación de jurados para casos criminales fue debatida desde la primera mitad del siglo xIx y que la participación lega en la justicia se hizo evidente en la práctica mediante la delegación de funciones judiciales por parte del gobernador a autoridades nombradas de forma extraordinaria. En ese contexto, la preeminencia de una justicia lega o letrada fue eje de discusiones, tal como lo evidencian, por ejemplo, ciertos debates académicos de los años veinte en Buenos Aires. De hecho, la implementación de jurados ya aparecía en los borradores constitucionales de 1819 y 1826, aunque aclaraban que "esto ocurriría cuando lo permitan las circunstancias". La Constitución nacional sancionada en 1853 retomó los juicios por jurados para resolver los casos criminales y lo estableció como parte del sistema judicial republicano en varios artículos que nunca se anularon y que se proyectaron en el tiempo (Barreneche 2007). A pesar de ello, la Corte Suprema argentina falló que se trataba de una cláusula programática de la Constitución y por ende discrecional para el legislador. Debido a esta y otras excusas nunca se puso en práctica hasta la actualidad, anulando esta vía de participación ciudadana en la justicia. Más allá de esto, en las provincias argentinas del siglo xIx, la justicia letrada tuvo que convivir con diferentes formas de justicia lega en la práctica: por una parte, la justicia de instrucción penal en manos de la policía; por otra, el sistema de justicia paralela o de excepción impulsado desde los ejecutivos provinciales, que incluía a jueces extraordinarios nombrados por el gobernador, tribunales espaciales y magistrados de ocasión a cargo de juicios y procedimientos abreviados.

Por su parte, nuevas aproximaciones y debates discuten sobre el valor del tributo para la ciudadanización y analizan a la contribución fiscal como una instancia de definición de los compromisos cívicos con el Estado (Irurozqui 2006). La estructura tributaria imperante luego de la sanción de la constitución nacional de 1853, imponía una nueva filosofia impositiva que requería, también, la construcción de una nueva cultura fiscal. De este modo, la constante reformulación de la categoría de ciudadano incluyó no sólo las obligaciones y derechos políticos sino que incorporó también la noción de ciudadanocontribuyente. En este nuevo diseño de poder, la lealtad y la colaboración con la "patria" comenzaron a medirse también a través del cumplimiento tributario. En este marco, la presión fiscal sobre los contribuyentes se convirtió en una herramienta permanente del Estado provincial para ordenar sus cuentas y 
sostener el andamiaje político-administrativo en pleno proceso de construcción. Ello no fue un proceso carente de conflictos y fracasos. En general, en las provincias, los rubros más exigidos fueron el de contribución directa y el de patentes, lo que provocó una fuerte presión sobre este segmento de contribuyentes. Los ciudadanos en general y los sectores populares en particular adoptaron una variedad de formas de resistencia entre las que el reclamo, los pedidos de rebaja o exoneración, la morosidad y la evasión resultaron las más visibles.

Estos recientes abordajes sumados a la producción analizada en los apartados anteriores demuestran que la interpretación del ciudadano como sujeto de acción con capacidad de producir y a su vez de modificar lo público es la óptica que permite abordar a la construcción ciudadana decimonónica en toda su complejidad y especificidad. Los tres componentes de su dimensión política analizados aquí -el voto, la opinión y las armas- muestran, por un lado, las vías de conexión entre ciudadanía, política y gobierno en el siglo xIx. Por otro, los derechos y compromisos que definen al ciudadano en clave política. Por su parte, los nuevos estudios concentrados en el área de la justicia y de la fiscalidad evidencian otros ámbitos de acción y negociación ciudadana que marcaron también las cosmovisiones en tensión en torno al Estado, su funcionamiento y el rol de la ciudadanía en las repúblicas decimonónicas. 


\title{
MODERNIDAD, MODERNIZACIÓNY SUFRAGIO UNIVERSAL: LA EXPERIENCIA DE AR GENTINA, BRASIL, CHILEY URUGUAY
}

\author{
Verónica Giordano
}

Este capítulo aborda un tema clásico de la modernidad: la tríada democracia-ciudadanía-sufragio, en referencia a la experiencia de Argentina, Brasil, Chile y Uruguay. Lo hace, no obstante, desde una perspectiva que sólo recientemente ha sido engrosada. Se trata de la hibridación de disciplinas (Dogan/ Pahre 1993), en particular, una nueva "ola" de sociología histórica que dialoga con los estudios de género (Adams/Orloff/Clemens 2005).

El sufragio universal, y para precisar más aún los términos, el sufragio de varones y mujeres, es la dimensión a través de la cual recorto y la hipótesis que sostengo es continuación de un trabajo anterior (Giordano 2012), en el que planteo que la familia es la matriz de los derechos de ciudadanía civil, política y social, y llamo la atención acerca de la condición de "ciudadanas incapaces" de las mujeres, habilitadas para votar pero consideradas jurídicamente incapaces en razón de la obligatoria subordinación a la potestad del varón en la estructura del matrimonio. Propongo pensar el problema a partir de las "grandes preguntas" de las ciencias sociales, es decir, relacionando la "historia interna" de los movimientos de mujeres con las historias políticas nacionales (Scott 1996: 2).

El capítulo aborda la institucionalización del sufragio universal en Argentina, Brasil, Chile y Uruguay en tanto proceso imbricado en el proceso de modernización que construyó modernidad en América Latina. Este proceso no 
es desviado ni separado de los procesos europeos. Como se espera mostrar en las páginas que siguen, la modernidad, como "cambio epocal", "global" (Therborn 1992), tuvo un ritmo que se historizó de modo particular en América Latina pero que siguió el mismo compás en ambas "rutas", la europea y la latinoamericana. Se trata de desagregar los procesos europeos y latinoamericanos ("las rutas", según Therborn) de modernización para poner de relieve la diversidad y multiplicidad de las formas de ciudadanía (europeas y latinoamericanas) constitutivas de la modernidad, que por otra parte están necesariamente interconectadas entre sí.

Así, en Argentina, Chile, Brasil y Uruguay el sufragio universal, inclusivo de las mujeres, estuvo en debate contemporáneamente a los sucesos que en Europa, desde la Revolución Francesa, condujeron a la universalización del sufragio exclusivamente masculino en 1848 en Francia y a la sanción pionera del voto femenino en Finlandia, Noruega y Dinamarca, en 1906, 1913 y 1915, respectivamente. En la década de 1920, las referencias a la legislación sobre derechos políticos femeninos de Alemania e Inglaterra (1919) y de Suecia y Estados Unidos (1920) no estuvieron ausentes de los debates de los diferentes proyectos de ley que se discutieron en los Congresos en Argentina, Brasil, Chile y Uruguay. Pero el sufragio universal, como en Europa, se concretaría en "olas" sucesivas, siendo los años de la segunda posguerra un momento democratizador, pues el voto femenino fue sancionado en Argentina en 1947 y en Chile en 1949, mientras que, en Europa, Francia lo hacía en 1944 e Italia en 1946. Es importante destacar que en Brasil y Uruguay había sido legislado en 1932, pero el orden político estuvo severamente restringido hasta su democratización en los años cuarenta.

\section{ModernidAd y MODERNIZACión en AmÉrica LATina}

Göran Therborn, un sociólogo sueco preocupado por el futuro de la tradición marxista en el contexto actual de agudas transformaciones culturales y políticas, se encuentra entre aquellos que han aportado al descentramiento de la modernidad como categoría eurocéntrica. Desde mi punto de vista, su aporte más preciso es el que considera que la modernidad no es solamente múltiple, sino que las modernidades coexistentes tienen interrelaciones, tanto actuales como históricas (Therborn 2003). Su perspectiva geohistórica es relevante y en su historia mundial del surgimiento del derecho de voto (Therborn 1992) identifica cuatro "rutas hacia y a través de la modernidad". 
En la trama que él construye hubo una ruta, la europea (y más precisamente la europea noroccidental) que fue asumida como universal, claro está, en un momento imperialista del cual no estuvieron exentas las ciencias sociales y sus visiones hegemónicas. Sin embargo, el proceso europeo estuvo lejos de ser uno, lineal y sin conflictos como podría desprenderse de una lectura estructural-funcionalista de T. H. Marshall. Como sostiene Therborn, Europa tuvo un "largo siglo de democratización" entre 1789 y 1918, y a partir de allí hubo tres "olas" de democratización: en los años de la segunda posguerra, en los años setenta del siglo xx y entre 1989-1991, de manera contemporánea a la crisis y finalización de los denominados socialismos reales.

Como se ha dicho antes, y se espera mostrar en los apartados que siguen, desde un punto de vista comparativo, la "ruta de los Nuevos Mundos", categoría que Therborn utiliza para clasificar a América Latina, no sólo no está separada de aquella ruta "pionera" sino que tiene la misma historicidad.

En referencia a América Latina, Waldo Ansaldi (2007: 62) sostiene un argumento que es consistente con los que hasta aquí hemos esbozado:

La apelación a principios de legitimación liberal incluye los de representación, ciudadanía y democracia. Mas el movimiento histórico real está signado por un profundo desfase entre fundamentos y práctica. En algún sentido, tal fractura no es privativa de las experiencias latinoamericanas, pues la misma se aprecia en Europa occidental. Resumiendo en extremo, puede decirse que la cuestión se plantea en términos de transformación de principios universales en prácticas singulares.

En América Latina, la idea de la modernidad llegó desde Europa cuando el territorio americano era todavía colonial. Sus valores y significados se combinaron con otras categorías de ordenamiento de la sociedad, pues como sostiene Florestan Fernandes (1973: 195), el orden poscolonial se resuelve como "modernización de lo arcaico" y "arcaización de lo moderno", y como señala el mismo autor "las clases sociales se superponen a otras categorías sociales de agrupación, de solidaridad y de articulación con las sociedades nacionales", como las etnias o los estamentos. Respecto a la existencia de de exclusiones, Ansaldi señala que

Tres grandes exclusiones caracterizan el proceso europeo: las clases "peligrosas”, las mujeres y los dementes. En América Latina se añade una cuarta, de orden étnico: la de los indígenas y los afroamericanos.

De modo que la institución del sufragio universal con restricciones para los analfabetos (de cualquier sexo) está íntimamente vinculada a ese proceso 
por medio del cual unos grupos/clases/sectores son integrados o no. En sociedades estructuralmente agrarias y racialistas la condición de analfabeto está muy frecuentemente anudada a clivages de clase ("peligrosas") pero también de etnia (indígenas, afroamericanos o inmigrantes). Está claro que en este cuadro, las mujeres sufren una exclusión múltiple, pues están integradas a algunas de estas clasificaciones. Asumir categorías "ubicadas del otro lado de la división modernidad/tradición, como por ejemplo raza, etnicidad y género" pone en evidencia el "desorden de la modernidad" (Lo 2005: 392 y 386).

\section{Chile, I875: El IMPUlso CONSERVADOR A LA AMPLIACIÓN DEL SUFRAgiO}

Las rutas del liberalismo y del conservadorismo pueden seguirse a través de las confrontaciones que se dieron en toda América Latina. En Chile esa confrontación se resolvió tempranamente en el año 1830 a favor de los conservadores. La Constitución de 1833, de corte fuertemente presidencialista y autoritario, estableció el sufragio para "los chilenos" mayores de edad, alfabetos, que tuvieran renta (art. 8). Chile iniciaba un proceso de centralización del poder que en otros países de América Latina llevó más tiempo. La "ruta" chilena hacia la modernidad estaba interconectada a la europea, ya que uno de los juristas notables de la época, Mariano Egaña, que participó del diseño de la Carta de 1833, se inspiró en las Constituciones de la Francia napoleónica (1792 y 1795) y de las ideas de la Restauración (1814), en las cuales se consignaban criterios restrictivos del voto que fueron adoptados en Chile de modo muy similar.

Aunque el periplo chileno de construcción de un sistema político y de representación ciudadana es analizado como un desarrollo político gradual y pacífico, Tomás Moulian cuestiona esta interpretación y señala que detrás de las "ostentosas apariencias de una autoridad fuerte", había una cierta fragilidad del poder. Esta fragilidad se puso de manifiesto a partir de la década de 1860, cuando estallaron los conflictos religiosos y el liberalismo avanzó "como ideología culturalmente penetrante" (en Ansaldi y Giordano 2012: 259).

Por otra parte, debido al predominio de las ideas conservadoras, no extraña que la ampliación del sufragio, propuesta en 1874 por el diputado Zorobabel Rodríguez, haya sido una iniciativa de esa corriente. Pero también debe leerse como parte de la estrategia conservadora para debilitar la fuerza electoral y la representación en el Congreso de los liberales, aliados con el Partido Radical para las siguientes elecciones. Esta política se debía a que, para 1874, la Fusión Liberal-Conservadora, alianza que había encumbrado al presidente 
liberal Federico Errázuriz, se había quebrado ante los sucesivos conflictos entre el presidente y los conservadores. En este escenario, en noviembre de 1875, cuando tal como estipulaba la ley debía realizarse la inscripción en el registro electoral para los comicios del año siguiente, algunas mujeres de la ciudad de San Felipe y del departamento de La Serena acudieron a las Juntas Calificadoras de Elecciones logrando inscribirse. ${ }^{1}$

Hay evidencia para afirmar la filiación conservadora de estas mujeres. La Junta de Santa Lucía en La Serena estaba presidida por Domingo Ortiz, sacerdote y rector del seminario de esa localidad, que aprobó la inscripción. Asimismo, según una nota publicada en el Estandarte Católico, algunas de las mujeres calificadas en San Felipe se habían manifestado favorables a la candidatura de Benjamín Vicuña Mackenna, que en ese momento contaba con el respaldo del Partido Conservador.

En San Felipe, una de las mujeres calificadas fue Domitila Silva y Lepe, viuda de un ex intendente de la provincia. $^{2}$ La Junta Calificadora de esa ciudad aprobó la iniciativa con el argumento de que en la categoría

ciudadanos activos con derecho a sufragio están evidentemente comprendidas las mujeres no solo porque la lei no las ha escluido, sino también porque la palabra ciudadano se emplea con referencia a los dos sexos, desde que ese es el sentido que tiene en el lenguaje natural i obvio, i hasta aún en el jenuino o gramatical (en Maza Valenzuela 1995: 159).

En La Serena, entre las mujeres que fueron calificadas por la Junta de Santa Lucía, había algunas casadas, cuyos maridos habían acompañado la iniciativa con su firma "como prueba del permiso que les daban a sus esposas para que se calificasen” (en Maza Valenzuela 1995: 160; el subrayado es mío). Unos días antes de estos episodios, en el Senado, el legislador liberalVicente Reyes había protestado contra la inscripción de dos sacerdotes (en el supuesto que estaban legalmente impedidos de voto) con el argumento de que

el antecedente que con este motivo viene a sentarse es funesto y pernicioso, porque mañana no habría razón para negarse a inscribir a una mujer que tenga la libre

1 También hay evidencias de la inscripción de otra mujer, Clotilde Garretón de Soffia, en la Junta Calificadora de Casablanca (provincia de Valparaíso).

2 La historiografía no es concluyente respecto de cuántas fueron las mujeres que se inscribieron en San Felipe. Pero las fuentes son precisas acerca del caso de Domitila Lepe y Silva (Maza Valenzuela 1995). 
administración de sus bienes (...) los señores Senadores saben que los regulares no son ciudadanos activos, porque el Código Civil establece que tienen inhabilidad moral para ejercer sus derechos políticos, ya que no pueden ejercer los civiles (en Maza Valenzuela 1995: 158; el subrayado es mío).

A raíz de esto, el senador Reyes propuso modificar la ley en el sentido de excluir expresamente al clero y a las mujeres del derecho de sufragio. Pero enseguida fue convencido por otro senador liberal, Melchor de Santiago Concha, de quitar la cláusula de exclusión de género por considerar insólito el caso de mujeres votantes (Maza Valenzuela 1995: 158). Finalmente, las elecciones se celebraron en 1876, sin el voto de las mujeres (Errázuriz Tagle 2005).

En 1884, los liberales en el poder sancionaron una nueva ley electoral que excluía expresamente el voto femenino. Los acontecimientos de 1875 fueron sin duda aleccionadores. La exclusión fue ratificada por la Constitución de 1925. La restricción censitaria había sido anulada (1874 y 1888) y una nueva Carta, en 1925, ratificó la anulación, pero estableció el voto secreto para los chilenos mayores de edad y alfabetos. Las mujeres seguirían excluidas durante algunas décadas más.

De este tramo del proceso de ampliación del sufragio interesa subrayar dos elementos. En primer lugar, los argumentos de restricción del voto femenino vinculados al estatuto civil dentro del matrimonio. En segundo lugar, que la ruta de Chile hacia el sufragio universal tiene algunos rasgos similares a los de Europa protestante y la de Estados Unidos, pues los sectores conservadores chilenos, igual que los conservadores protestantes anglosajones, valoraron positivamente el voto femenino como una forma de aumentar su poder frente a sus oponentes. ${ }^{3}$ Aunque el tema del voto formó parte del debate y del conflicto político chileno del siglo xIx las iniciativas y los debates sobre la inclusión política de las mujeres, como en la Europa latina y católica, recién conducirían a la efectiva sanción del voto femenino con la ola democratizadora de los años cuarenta, cuando se sanciona la ley de sufragio femenino (1949).

\section{Argentina y Brasil, I890: LA CRISIS EN LA FORMA DE DOMINACIÓN}

El año 1890 es otro hito del proceso de construcción de la democracia y la ciudadanía en América Latina. Como Chile, también Brasil tuvo una experiencia temprana de centralización del poder en el Estado.Y en ambos

3 Para un estudio comparativo, Evans (1977). Sobre Francia, Scott (1986). 
casos hubo crisis de la dominación más o menos simultáneamente. En Chile, el pacto, fuertemente presidencialista, se reformuló como República Parlamentaria en 1891 mientras que en Brasil, la reformulación se dio en términos republicanos frente al dominio imperial en 1889.

A diferencia de Chile, donde las reformas electorales de 1888 y 1890, que reforzaron el voto secreto y la prescindencia de la intervención oficial, así como la idea de un sufragio excluyentemente masculino, en Brasil, las pujas por la liberalización del orden y su ampliación a las mujeres tuvo cierto impulso en los debates públicos que tuvieron lugar en la prensa y en los debates parlamentarios.

En el contexto de la proclamación de la República, el periódico O 15 de Novembro do Sexo Feminino, fundado por Francisca Senhorinha da Motta Diniz, hizo una sostenida defensa del derecho a voto para las mujeres. ${ }^{4}$ En 1891, cuando la Asamblea Constituyente sancionó una nueva Constitución, se discutió fervientemente el alcance de la universalidad del voto. La ruta del republicanismo que había sido importante en algunos países latinoamericanos se hacía más compleja con los debates alrededor de la ciudadanía femenina.

En esos mismos años, Argentina también estaba atravesando una fuerte crisis de la forma de dominación, pues había estallado el conflicto político con la Revolución del Parque de 1890. Mezclado con una crisis económica, el presidente de la nación fue severamente cuestionado y hasta se produjo una rebelión armada. En la tribuna de la oposición al gobierno de Miguel Juárez Celman (1886-1890), el diario El Censor, imbuido de los cambios que se estaban produciendo en el mundo sobre la materia, puso en debate el sufragio universal.

A propósito de la promulgación de una nueva Constitución para la provincia de Buenos Aires, finalmente aprobada en octubre de 1889, El Censor afirmaba que las opiniones en juego reunían a partidarios del sufragio universal, a defensores del voto alfabeto y, en el medio, a quienes consideraban que el derecho a voto correspondía a los "varones o hembras" que detentasen la libre administración de sus bienes. Quienes sostenían la primera posición, argüían que se trataba de un derecho heredado de la participación en las guerras de independencia, de las que habían tomado parte las "masas iletradas al mando de ilustres generales". Los segundos fundamentaban su postura en un mínimo de instrucción, que sostenían que "no estaba prohibida a nadie". Por último, el

4 El periódico comenzó a editarse en 1873 en Campanha da Princesa, ciudad del sur de Minas Gerais, con el nombre O Sexo Feminino. En 1875, se trasladó a Río de Janeiro. La campaña por el voto femenino tomó firme rumbo en el contexto de la proclamación de la República en 1889. 
grupo que anudaba los derechos políticos a los derechos civiles argumentaba del siguiente modo:

El sufragio popular para ser universal debe comprender a ambos sexos pues el actual no es más que el sufragio masculino, que la única excepción debe ser la de los incapaces, a menos que se pruebe que los niños y los locos tienen para manejar el gobierno la misma aptitud que para decir verdades; y que saber leer y escribir no implica preparación política mientras que no se lea y se escriba nada que tenga relación con las instituciones gubernativas. Parece que en esta tercera opinión está la verdad o por lo menos la lógica. (...) Mirado el voto como una garantía de los derechos civiles, lógicamente les corresponde a las mujeres, que tienen derechos civiles tan importantes y tan sagrados como los de los hombres. Es claro que las mujeres casadas no tendrían voto, en este sistema, por la dependencia en que se hallan al respecto de sus maridos (El Censor, 13 de agosto de 1889; el subrayado es mío).

La prensa juarista expresó su rechazo a la inclusión de las mujeres desde el punto de vista político y a la posibilidad de que estuvieran presentes en el Congreso nacional. El diario Sud-América decía:

¿Por qué, entonces, no concurren las damas?

No las dejan entrar; el reglamento no lo permite y esta falta de permisión es tradicional. (...) Hasta dos o tres años, siendo permitido el voto en elecciones municipales a las damas, en la ciudad de San Juan ocurrióse a éstas presentarse a las urnas. ¡Fueron... oyeron y huyeron! Y también en seguida, se quejaron y protestaron. ¿De qué? De las palabrotas que proferían los hombres, tanto del mismo bando a que se habían plegado las damas como del bando contrario. ¿A quién la culpa y la pena? ¿A los que dijeron o a los que fueron a oírlas? La libertad... es libre, con todas sus consecuencias. Y ahí quedó el caso (Sud-América, 24 de diciembre de 1889; el subrayado es mío).

Aunque una de las rutas del liberalismo no era refractaria a la participación de las mujeres en política, los liberales argentinos que se expresaban en el Partido Autonomista Nacional no lo eran. Por esa época se estaba conformando una tradición que colocaba a las mujeres en un lugar marginal y se encuentra expresado con toda claridad en el artículo de Sud América que retoma argumentos que habían sido expresados en el Código Civil sancionado en 1869. Según Sud América

...no se trata de si las damas pueden concurrir a las sesiones del Congreso, sino más bien de si deben concurrir. (...) Decía que a la pregunta de: ¿por qué no concurren las damas a nuestro Congreso? en vez de contestar: 
-Porque no pueden, si no las dejan entrar! -y de echar la culpa a los miembros del antiguo Cabildo- es menester decir llanamente la verdad:

-Porque no deben concurrir.

(...) Porque el Código Civil (art. 900) prohíbe el que las damas puedan ser testigos en los instrumentos públicos. (...) Porque según la ciencia constitucional, se ha excluido a las damas de las asambleas constitucionales.

No se me arguya en este último caso con la circunstancia de que en algunas partes del derecho electoral municipal les está acordado. La excepción confirma la regla y luego en tal caso, las damas están consideradas como simples contribuyentes, asimilados - perdonen ellas la palabra- a los pagadores masculinos de impuestos municipales, por razones obvias de enumerar (Sud-América, 24 de diciembre de 1889; el subrayado es mío). ${ }^{5}$

Como es evidente, aunque hubo liberales que sostuvieron firmemente el sufragio femenino, todavía pesaban posiciones inclinadas a una extensión limitada o condicionada por la educación y el estado civil. A diferencia de Brasil, donde el movimiento republicano abrió espacios que fueron aprovechados por las mujeres para colocar sus demandas específicas, en la Revolución del Parque no hubo un movimiento de mujeres organizado en torno a la demanda de sufragio, aunque este sí estuvo en debate en el ámbito público y estuvo presente en poco tiempo después en las plataformas políticas del Partido Socialista ${ }^{6}$.

Cuando en 1912 se sancionó la ley de sufragio universal, obligatorio y secreto, expresión de una de las fórmulas de compromiso con la que se resolvió la crisis de la dominación oligárquica abierta en 1890, las mujeres fueron explícitamente excluidas del voto en virtud de un mecanismo que pone en evidencia el carácter excluyentemente masculino de la universalidad que se invocaba. El derecho al sufragio quedó anudado al deber de cumplir con el servicio militar, pues quedó en manos de la autoridad militar la confección del sufragio. Aunque algunas mujeres reclamaron el derecho a ser incluidas en el padrón militar para que se las habilitara electoralmente lo cierto es que, como sostiene Adriana Valobra (2008: 3), "las mujeres no podían reclamar un derecho por un deber que no cumplían", lo que no implica que algunas organizaciones feministas y de mujeres no reclamaran el derecho a sufragar.

5 La historiografia no es concluyente respecto de las implicancias de la legislación del voto de las mujeres en San Juan. Véanse Valobra (2010: 18) y Lacoste (2008: 56). Muy probablemente, la nota periodística se refiera a la elección de 1883.

6 Cocca (1948:37-40) ofrece un panorama de voces masculinas que se manifestaron a favor del sufragio femenino hacia 1890 . 
En Brasil, la proclamación de la República en 1889 trajo consigo cambios en la legislación electoral. Se habilitó el voto directo a todos los hombres alfabetos mayores de 21 años, pero se excluyó de este derecho a los varones analfabetos, los mendigos, los militares de carrera y a todas las mujeres. No obstante, durante la Asamblea Constituyente que en febrero de 1891 promulgó la nueva Constitución se discutió la inclusión de las mujeres en el estatus de ciudadanía política.

En la sesión del 10 de diciembre de 1890, dos constituyentes, Baptista Sá Andrade y Cesar Zama, propusieron redactar el artículo 70 de modo tal que incluyera a las ciudadanas solteras o viudas que tuvieran diploma de las Facultades de Derecho, Medicina o Farmacia, o que estuviesen a cargo de establecimientos docentes, industriales o comerciales.

A pesar que a las mujeres casadas se las excluía explícitamente del derecho de sufragio, en la sesión del 12 de enero de 1891, cuando se discutió la propuesta, el constituyente José de Mello Carvalho Muniz Freire intervino para afirmar que su aprobación en el Congreso significaría decretar "la disolución de la familia brasileña" (Osta 2009: 5190; el subrayado es mío). El voto femenino (de todas las mujeres, de las solteras, de las viudas o de las casadas) era considerado una aspiración "inmoral y anárquica".

La nueva Constitución, que establecía elementos claramente rupturistas, como la separación de la Iglesia y el Estado, siguió apegada a concepciones del orden arraigadas en la moral (una moral fuertemente imbricada con el catolicismo). En este marco, el sufragio universal se edificó sobre bases estrechas: el voto alfabeto (la Monarquía no exigía esta condición) y exclusivamente masculino.

Así, en Argentina y Brasil, y como vimos antes también en Chile, el sufragio universal, inclusivo de las mujeres, estuvo en debate contemporáneamente a los sucesos que en Europa, desde la Revolución Francesa y hasta 1918, "el largo siglo de democratización”, como lo denomina Therborn, condujeron a la universalización del sufragio con el reconocimiento del derecho a sufragar para las mujeres solamente en unos pocos países del norte de Europa. No sólo las rutas de cada caso tuvieron la misma historicidad, sino que también el argumento para la exclusión de las mujeres de la noción de sujeto universal fue similar. Tanto en Argentina como en Brasil, se invocaba la inscripción de las mujeres en la esfera privada, legitimada por su condición legal civil. No en vano, en Francia, en 1904, año del centenario del Código Civil, un grupo de feministas quemó públicamente el texto que era marco de su sometimiento (Scott 1996: 100). Para las mujeres de unos y otro países, el derecho a sufragio llegaría con la "ola democratizadora de los años cuarenta". 
URUGUAY, I9I7: EL REFORMISMO TUTELAR DEL BATLLISMO Y SU FRENO

De acuerdo con la Constitución de 1830 (cap. III, art. 11), en Uruguay no votaban los menores de edad, los sirvientes a sueldo, los peones jornaleros, los soldados de línea y los analfabetos. De las mujeres no se estipulaba expresamente su condición, pero por uso y costumbre se entendían las categorías "hombre" y "ciudadano" con exclusiva referencia al varón.

Como otros espacios hispanoamericanos, el Uruguay del siglo XIX estuvo atravesado por los enfrentamientos armados entre los grupos que se disputaban la construcción del nuevo orden. En este caso los dos bandos políticos enfrentados eran el Colorado y el Blanco. En el conflicto armado de 1903-1904, el caudillo blanco Aparicio Saravia fue derrotado por el ejército leal al presidente colorado José Batlle y Ordóñez. Así, se afirmó una fase de modernización en la cual, después del impulso modernizador militar de las presidencias de Lorenzo Latorre (1876-1880), Máximo Santos (1882-1886) y Máximo Tajes (1886-1890), la construcción del nuevo orden estuvo conducida por el poder civil. Al cabo de las guerras entre caudillos, la balanza se inclinó a favor del centralismo, con Batlle a la cabeza.

Batlle fue presidente dos veces: entre 1903-1907 y 1911-1915. Con el batllismo se afirmó una política reformista que, entre otras cuestiones, tuvo un ímpetu fuertemente liberal y anticlerical y, de modo singular, un reformismo favorable a la ciudadanización "tutelar"; esto es, desde arriba y con una fuerte impronta de "protección” a los grupos socialmente más "débiles”. Esta política de ciudadanización fue inclusiva de las mujeres, a las cuales se buscaba dotar de derechos en las tres esferas: civil, política y social.

El batllismo buscó afianzar su proyecto en una nueva Constitución. Uno de los puntos de la reforma que se discutió en la Asamblea Constituyente de 1917, que aquí interesa señalar como decisivos, fue la institucionalización del voto universal. Graciela Sapriza (2011: 359) señala que "Batlle y su familia se radicaron en Europa durante el interregno de las dos presidencias, es decir, entre 1907 y 1911, en momentos en que las corrientes feministas -y especialmente el sufragismo- intensificaban allí sus campañas". En este sentido ese conocimiento puede haber influido en las políticas de Batlle como presidente.

Pero también el criterio de universalidad fue asumido como inclusivo de varones $y$ mujeres tanto por las fuerzas liberales como por otras dos fuerzas que habían hecho su ingreso en la arena pública: el socialismo y el primer feminismo. Un rasgo común con la experiencia política en Argentina. 
En 1914, el diputado Héctor Miranda había presentado el primer proyecto de derechos femeninos. Luego, las feministas se organizaron, desde el Consejo Nacional de Mujeres, presidido por la médica Paulina Luisi, para defender sus derechos. El Consejo se había creado en 1916 al calor de los ímpetus reformistas (el proyecto de reforma de la Constitución databa de 1913). Los socialistas, en la voz de Celestino Mibelli, llevaron la cuestión de los derechos políticos de las mujeres a la Asamblea Constituyente de 1917.

Mibelli solicitó que se reemplazase el término "hombres" por el más extenso de "personas", pero la moción no fue apoyada. De inmediato, el Consejo Nacional de Mujeres, a través de su Comité Ejecutivo, decidió elevar una nota, que por la urgencia de la ocasión estuvo firmada por 54 mujeres, entre ellas presidentas o delegadas de las asociaciones de mujeres afiliadas al Congreso, "lo que suponía unos cuantos centenares de mujeres". 7

La nota, datada el 25 de abril de 1917, solicitaba los "derechos políticos y civiles para la mujer". Más tarde, en el primer número de la revista Acción Femenina (julio de 1917), órgano de prensa del Consejo, las feministas presentaron su Programa:

No hay tema que deba escapar a nuestra solícita atención. (...) derechos que hoy reclamamos las mujeres de todos los países del mundo (...) derechos civiles y derechos ciudadanos (...) Es necesario un doble trabajo de acción y de pensamiento para conseguir la nivelación de las costumbres y de las leyes (en Sapriza 1988: 92; el subrayado es mío).

Finalmente, los conservadores (de ambos partidos, el Nacional y el Colorado) ganaron la pulseada, poniéndole un "freno" al impulso reformista auspiciado por el batllismo. Los derechos femeninos quedaron atrapados en la lógica de la confrontación político-partidaria que obturó la convergencia de batllistas, socialistas y algunos liberales convencidos de la reforma.

Finalmente, la Constitución estableció el voto secreto para los varones pero no legisló sobre sufragio femenino. Al respecto, la feminista Paulina Luisi expresó:

Cuando oímos hace pocos meses, a los hombres encargados por el pueblo de reformar la carta magna de la Nación clamar con inconsciente suficiencia que la

7 Testimonio de Carmen Onetti, en La mujer uruguaya reclama sus derechos políticos, [Discursos pronunciados en la Universidad en el "meetin público" del 5 de diciembre de 1929], Montevideo, 1930 (¿̨), p. 50. 
misión de la mujer es la guardia del hogar y la procreación de los hijos, pensábamos con amargura en el hogar de las sirvientas como nosotras mujeres; pensábamos en los miles de mujeres que, a la par del hombre, pero con menos salario que él trabajan de sol a sol (...) y nos preguntábamos qué salvaje ironía o qué obtusa inconsciencia inspiraban las palabras de aquellos constituyentes que no tuvieron reparo en negar a la mujer el derecho a la vida ciudadana (...) (Acción Femenina, julio de 1917, en Sapriza 1988: 92).

No obstante, la nueva Carta estipuló el mecanismo por el cual era posible sancionarlo en el futuro:

El reconocimiento del derecho de la mujer al voto activo y pasivo, en materia o municipal, o en ambas a la vez, sólo podrá ser hecho por mayoría de dos tercios sobre el total de los miembros de cada una de las Cámaras (cap. II, art. 10).

Como se ha dicho al comienzo, y se ha visto hasta aquí, la "ruta de los Nuevos Mundos", según denomina Therborn a la seguida por América Latina, está relacionada temporalmente y con los tópicos centrales en debate con la ruta "pionera" de Europa. En los cuatro casos estudiados, el siglo XIX fue un "largo siglo de democratización", similar al proceso vivido en Europa. En América Latina, el caso de Uruguay es paradigmático por el auspicio del batllismo de la participación política de las mujeres, pero incluso allí se impusieron las visiones más tradicionales que postergaban el voto femenino en razón de las obligaciones domésticas impuestas a las mujeres (con o sin salario).

\section{Brasil y URUguay, I932: CRISIS DE LA FORMA DE DOMINACIÓN}

Hacia 1920, el sufragio universal y con él los derechos políticos femeninos ya eran un punto irrecusable de discusión en la escena pública. Sin embargo, salvo algunas iniciativas en el nivel municipal, este sería legislado en el nivel nacional recién en las siguientes décadas, siendo pioneros Brasil y Uruguay en $1932 .{ }^{8}$

8 En Argentina, las Constituciones provinciales legislaron sobre sufragio femenino en el nivel municipal en 1921 en Santa Fe y en el nivel provincial en 1927 en San Juan. Pero la legislación fue efímera. En Brasil, se legisló sobre sufragio femenino en el nivel estadual en Río Grande do Norte en 1927. Pero los votos fueron anulados por la Comisión de Poderes del Senado. 
En Brasil, después de la Revolución de 1930, la dominación oligárquica insinuó recomponerse con la constitución de Frentes Unicas (en São Paulo, Minas Gerais y Rio Grande do Sul), reuniendo a sectores aperturistas y tradicionales, con una pronta proyección en el nivel federal. Estos Frentes plantearon como objetivos prioritarios la redacción de un nuevo Código Electoral y la convocatoria a una Asamblea Constituyente (Ansaldi y Giordano 2012: 583). En estas circunstancias, y ante la radicalización de los Frentes, donde algunos sectores se inclinaban por acciones golpistas en alianza con los militares afines, Getúlio Vargas hizo concesiones a fin de asegurarse el triunfo. El 24 de febrero de 1932 decretó un nuevo Código Electoral (Decreto n 21.076) y enseguida convocó a elecciones para una Asamblea Constituyente.

El decreto estipuló el voto "sin distinción de sexo" (art. 2), con exclusión de los analfabetos (art. 4). El texto ampliaba sustantivamente los términos esgrimidos en el anteproyecto que en agosto de 1931 recibiera Vargas de la Subcomisión Legislativa encargada de la reforma de la ley electoral (nombrada en diciembre de 1930). Este anteproyecto estipulaba la inscripción como electoras de las mujeres solteras y viudas con renta propia; las mujeres casadas que ejercieran comercio o industria o profesión con funciones autorizadas por el marido (art. 8); y las separadas o con marido ausente (art. 9).

Según su relator, João C. da Rocha Cabral, conceder la "perfecta igualdad política de los sexos" sería

destroçar num só momento, sem uma preparação prévia, uma tradição secular e um sistema de direito privado, em que a mulher casada ainda está colocada em situação desigual à do homem no que diz respeito à chefia do casal, administração dos bens, escolha do domicílio e da profissão daquela fora do lar (Cabral 2004: 18; el subrayado es mío).

En julio de ese mismo año se había reunido en Río de Janeiro el II Congreso Internacional Feminista. Ante los términos restrictivos del anteproyecto salido de la Subcomisión nombrada por Vargas, la feminista e ingeniera civil Carmem Portinho, sufragista comprometida al lado de Bertha Luz en la dirección de la Federação Brasileira pelo Progresso Feminino, reclamó ante el presidente: "todo o nada" (Rodrigues 1982: 87).

Finalmente, fue casi todo. El nuevo Código Electoral no distinguió entre sexos en cuanto al derecho a votar, pero sí en cuanto a la obligación, eximiendo a los hombres mayores de sesenta años y a las mujeres de cualquier edad.

La Constitución de 1934 ratificó el voto femenino, sin restricciones, y amplió el universo de votantes, corriendo el límite de edad de 21 a 18 años para ambos sexos. Ahora bien, nuevamente, respecto de la obligación de votar, el 
texto establecía que el sufragio femenino era obligatorio sólo para las mujeres que ejercieran una función pública remunerada. Como el sufragio estaba, además, limitado para ambos sexos por la cláusula de alfabetismo, lo cierto es que, finalmente, la reforma electoral sólo alcanzó a las pocas mujeres alfabetizadas y sólo obligó a las poquísimas que desempeñaran un cargo público y recibieran remuneración por ello.

Adicionalmente, en la década de 1930, fueron excepcionales los casos de mujeres que accedieron a la función de representación. En 1937, cuando Vargas disolvió el Congreso y promulgó una nueva Constitución (de fuerte corte centralista y autoritario), el impulso feminista encontró un límite infranqueable. Así, el sufragio femenino tuvo mayor impacto después de 1946, tras la caída de la dictadura del Estado Novo (1937-1945), que el mismo Vargas encabezó. La Constitución de ese año estableció la plena obligatoriedad del voto tanto para varones como para mujeres, pero mantuvo la cláusula de alfabetismo.

En Uruguay, el sufragio femenino fue legislado el 16 de diciembre de 1932 (Ley n ${ }^{\circ}$ 8.297). La ocasión era propicia. En 1929 se había creado la Comisión de Festejos del Centenario de la Constitución de 1830, bajo la presidencia del ex presidente batllista Baltasar Brum (1919-1923), autor de un proyecto de ley pionero sobre derechos civiles y políticos de la mujer. Aprovechando esta circunstancia de relevancia nacional, que interpelaba al espíritu cívico de todos, las feministas nucleadas en la Alianza Uruguaya de Mujeres, bajo el liderazgo de Paulina Luisi, se reunieron el 5 de diciembre de 1929 en la Universidad de las Mujeres en un mitin público "a favor de los Derechos Políticos de la Mujer”. ' La Alianza intensificó su campaña en 1930 y 1931.

La ley de sufragio femenino se aprobó en el contexto de un renovado, pero efimero, impulso reformista, "el segundo impulso", 1928-1933. En esta coyuntura, los senadores batllistas Lorenzo Batlle Pacheco y Pablo María Minelli presentaron un proyecto de sufragio femenino que sirvió de base para la ley finalmente sancionada en 1932.

Por su parte, Minelli había presentado un proyecto sobre derechos civiles femeninos en 1930. En su informe ante el Congreso sostenía:

Vuestra Comisión de Legislación ha deseado poner todo su empeño para que, en el año del Centenario de la Independencia Nacional, se sancione la re-

9 En 1919, Luisi concentraría sus esfuerzos en la más combativa Alianza Uruguaya de Mujeres. El Consejo, del cual participaban mujeres de la élite vinculadas a la beneficencia, se había revelado poco enérgico en su voluntad de cambio. 
forma legal que equipare a la del hombre la capacidad civil de la mujer soltera, viuda o divorciada, y que amplía la de la mujer casada en todo aquello que lo permitan los intereses de la familia y sus propios intereses (en Frugoni 1940: 37; el subrayado es mío).

El Senado aprobó el proyecto en junio de 1932, pero ahí se detuvo. A diferencia de la iniciativa de Brum, el proyecto de Minelli no otorgaba capacidad plena, sino que solamente ampliaba los derechos de las mujeres casadas.

Ese período se caracterizó por cierta polarización de las identidades políticas por encima de, y atravesando, las tradicionales identidades partidarias. En el Partido Colorado, con la muerte de Batlle y Ordóñez en 1929, se exasperaron las divisiones internas. En 1931 se celebró un pacto histórico, denominado por su principal detractor, el líder nacionalista Luis Alberto de Herrera, como "pacto del Chinchulín", también conocido como "pacto del tres y dos". El acuerdo estableció la repartición de cargos de la burocracia del Estado en esas proporciones entre los batllistas y los nacionalistas antiherreristas (blancos independientes, fracción minoritaria escindida del Partido Nacional). Éstos controlaban el Senado y tenían mayoría relativa en el Consejo de Administración, pero hay que subrayar que estas mayorías correspondían a una facción minoritaria dentro del partido. La fuerza mayoritaria, el herrerismo, en su oposición al acuerdo "del tres y dos" coincidía con los sectores no batllistas del Partido Colorado.

Mientras se profundizaba el enfrentamiento de las dos facciones internas del Partido Colorado, la batllista y la liderada por el presidente Gabriel Terra (en el cargo desde el $1^{\circ}$ de marzo de 1931), se consolidaba la alianza entre éste y el herrerismo. Cuando el Congreso aprobó la ley de sufragio femenino, por diversos motivos, el batllismo, el terrismo y el herrerismo coincidieron en dar su apoyo.

Según la interpretación de Silvia Rodríguez Villamil y Graciela Sapriza (1984), hubo una utilización demagógica del voto por parte de las fuerzas conservadoras. Las autoras señalan que el colorado Terra, oportunistamente, lanzó la propuesta de creación de un Partido Feminista, al que se suscribieron conspicuas mujeres del primer feminismo como Sofia Álvarez Vignoli de Demicheli y otras figuras destacadas como Sara Rey Álvarez (mientras que otras, como Paulina Luisi, la rechazaron). ${ }^{10}$ Según María Laura Osta (2008),

10 Sara Rey Álvarez había vuelto a Uruguay en 1928 (después de tomar contacto con el feminismo europeo en Bélgica e Inglaterra, donde había estudiado Filosofía y Sociología (Lavrin 2005: 431). En 1933, fundó el Partido Independiente Democrático 
en razón de la fuerte movilización y compromiso de las mujeres, el sufragio fue "una conquista femenina".

Terra buscaba reformar la Constitución a fin de eliminar el gobierno colegiado, y apelaba para ello a la masa electoral femenina. Elegido democráticamente en 1931, Terra instauró una dictadura en 1933. El voto femenino se había sancionado, pero la democracia quedaba en suspenso.

En 1934, Terra convocó una Asamblea Constituyente que reformó la Carta en el sentido deseado y lo nombró presidente de jure. El nuevo texto eliminó el Consejo de Administración y estableció un Ejecutivo fuertemente centralizado, con un Consejo de Ministros que garantizaba la coparticipación de las fuerzas mayoritarias en el gobierno. También estipuló la división por mitades de las bancas del Senado entre las fracciones con más votos de los dos partidos mayoritarios (Senado “del medio y medio"), lo cual beneficiaba a terristas y herreristas.

En materia de derechos de las mujeres, ésta fue la primera Constitución que introdujo la igualdad expresa entre los sexos y ratificó el voto obligatorio para "todos los hombres y mujeres" (caps. I y II).

Así, las reformas de Brasil y Uruguay tuvieron impacto real recién en los años cuarenta. En Brasil, la dictadura del Estado Novo (1937-1945) interrumpió la práctica de elecciones. En Uruguay, las primeras elecciones nacionales de las que participaron las mujeres fueron en 1938. La incidencia del voto femenino se hizo sentir en las elecciones de 1942, cuando una nueva Constitución disolvió el "Senado de medio y medio" y adoptó el sistema de representación proporcional integral. Ese año asumieron, en la Cámara de Diputados, la colorada Magdalena Antonelli Moreno (por el ala reformista batllista) y la comunista Julia Arévalo; y en la Cámara de Senadores, las coloradas Sofía ÁlvarezVignoli de Demicheli (por el ala conservadora) e Isabel Pinto deVidal (por el ala reformista batllista).

En los dos países, los argumentos que estuvieron en debate para impedir la ampliación del voto a las mujeres fueron similares a los esgrimidos en otras ocasiones: la subordinación de la autonomía individual de las mujeres a la estructura familiar (subordinación, además, regulada por el Código Civil). Pero en esta ocasión, a diferencia de las otras, el voto femenino fue efectivamente sancionado. La coyuntura fue favorable y no estuvo exenta de cálculo político, un factor que parece haber tenido mucho más peso que la consigna de proclamar derechos específicos.

Feminista, que funcionó durante seis años. Su única presentación fue en las elecciones nacionales de 1938, con un resultado desalentador. 
En Brasil y Uruguay, como en Argentina y Chile, según veremos enseguida, el sufragio femenino se concretaría, no obstante, en "olas" sucesivas. Luego de los críticos años treinta, durante los cuales se cercenaron severamente las libertades políticas, los años de la segunda posguerra serán un "momento democratizador".

Argentina, I947 y Chile, I949: LA Ley de Sufragio femenino

En los años cuarenta la consigna de sufragio femenino no era nueva, pero había adquirido un nuevo tono a partir de un contexto internacional favorable, que recomendaba su aprobación - una posición no ajena a la idea de afirmar la democracia frente al totalitarismo-, como se desprende de las consideraciones de la Comisión Interamericana de Mujeres reunida en Chapultepec en 1945, que recomendaba hacer efectiva la aprobación de los derechos civiles y políticos de las mujeres acordada en la Conferencia de Lima en 1938.

Pero también los contextos nacionales fueron favorables, como en Argentina, donde se articularon iniciativas como las encabezadas por Juan Domingo Perón y su esposa Eva Duarte, o como en Chile, donde las iniciativas estuvieron encabezadas por el presidente Gabriel González Videla y su esposa Rosa Markmann.

En Argentina, en 1945, en su función de secretario de la cartera de Trabajo y Previsión, Perón creó la Dirección de Trabajo y Asistencia de la Mujer. Éste había traído consigo la idea de estructurar un espacio dedicado a la protección de la familia y la mujer similar al que había conocido en Italia (Barry 2011: 115). Desde esa Dirección, Perón impulsó enseguida la creación de la Comisión Pro Sufragio Femenino. Cuando en 1946, con el triunfo electoral del Partido Laborista, asumió el Ejecutivo, la iniciativa adquirió renovado cariz. El Primer Plan Quinquenal, ingresado al Congreso en octubre de ese año, incluía los derechos políticos de las mujeres y de los suboficiales de las Fuerzas Armadas. La sanción de los derechos políticos femeninos tomó rumbo firme a partir de 1947, con la enérgica acción de Eva Perón al frente de la campaña y de la movilización de las mujeres en el peronismo. El 23 de septiembre de 1947, por ley 13.010, se consagró el voto femenino. La ley fue apoyada en la votación en particular sólo por el bloque peronista, en una sesión por demás agitada y con evidente urgencia por conseguir la aprobación más allá de las formas propias del comportamiento parlamentario. El sufragio 
fue obligatorio y las mujeres fueron, en principio, igualadas a los hombres respecto de este derecho/deber. ${ }^{11}$

En 1945, cuando se inauguró la Comisión Pro-Sufragio Femenino, en su discurso, Perón sostuvo como objetivo:

dignificar moral y materialmente a la mujer equivale a vigorizar la familia.Vigorizar la familia es fortalecer la Nación, puesto que ella es su propia célula. Para imponer el verdadero orden social, ha de comenzarse por esa célula constitutiva, base cristiana y racional de toda agrupación humana (en Vázquez 2007; el subrayado es mío).

La reivindicación que Evita hiciera de las mujeres a comienzos de aquel año 1947 se inscribe en la misma tónica argumentativa: "Vibré contigo, porque mi lucha es también la lucha del corazón de la mujer que, en los momentos de apremio está junto a su hombre y su hijo, defendiendo lo entrañable" (en Valobra 2009: 51; el subrayado es mío).

La sanción del voto femenino en Argentina tiene, por lo menos, dos ribetes que aquí cabe subrayar. En primer lugar, como surge de estos fragmentos, el sufragio para las mujeres estuvo anudado a un proyecto estatal de refundación de la familia sobre bases nuevas, en el que las mujeres, y en particular las madres y las trabajadoras, tenían un rol primordial. En segundo lugar, tal como propone Carolina Barry (2011: 131), la sanción del voto femenino se explica en el conjunto "de las tácticas de incorporación y ampliación de las bases de sustentación que llevaba a cabo el peronismo al introducir en la política a sectores sociales que antes no estaban incluidos".

En Chile fue recién el 8 de enero de 1949, con el auspicio del presidente Gabriel GonzálezVidela (1946-1952), cuando se legisló sobre sufragio femenino con alcance nacional. La ley establecía el voto para los varones y mujeres, mayores de 21 años, que supieran leer y escribir.

El país ya tenía una ley de sufragio femenino en el nivel municipal (1934). ${ }^{12}$ Cuando en 1935, las elecciones municipales dieron un triunfo contundente a las fuerzas conservadoras, se creó el Movimiento Pro Emancipación de la Mujer

11 Véase una interesante interpretación de los alcances de la "igualación" en Valobra (2009 y 2010).

12 En Chile, el primer texto legal que habilitó el sufragio femenino en el nivel municipal data de 1931 (mujeres alfabetas mayores de 25 años, propietarias o profesionales). Pero no tuvo aplicación. El 9 de marzo de 1934, el Congreso promulgó una ley de sufragio femenino en el nivel municipal, extendida a todas las mujeres alfabetas. 
Chilena (MEMCH), para luchar por las históricas banderas del feminismo: los derechos políticos de las mujeres en el nivel nacional y la emancipación de las mujeres en todos los ámbitos. El MEMCH recibió influencias de la Asociación de Mujeres Universitarias, creada en 1931, con dos feministas destacadas:Amanda Labarca y Elena Caffarena. Fue una organización de composición heterogénea, conviviendo en ella posiciones conservadoras, liberales y de izquierda.

Singularmente, en Chile, a raíz del éxito electoral del Frente Popular (Partido Radical, Socialista y Comunista), con su candidato radical Pedro Aguirre Cerda (1938-1941), en 1938 la izquierda llegó al gobierno. El MEMCH dio su apoyo a la fórmula frentista, aunque sin perder autonomía como organización extrapartidaria.

Las feministas Elena Caffarena y Flor Heredia, afiliadas al MEMCH, fueron fervientes promotoras del voto femenino durante el gobierno de Aguirre Cerda, alcanzando a presentar un proyecto de derechos femeninos en el Senado. Pero la inesperada muerte del presidente de algún modo desorientó la lucha.

En 1944 se fundó la Federación Chilena de Instituciones Femeninas (FECHIF). La FECHIF concentró sus esfuerzos, con Labarca a la cabeza, por la obtención del voto. En julio de 1945, esta organización presentó un proyecto de ley al Congreso, con el apoyo de un grupo de legisladores de diversa extracción partidaria. Este proyecto, aunque demorado cuatro años, estaría en la base de la sanción de los derechos políticos para las mujeres de 1949.

En 1946, con el apoyo del Partido Radical y del Partido Comunista, y de la FECHIF (con voz, pero sin voto), asumió la presidencia Gabriel González Videla (1946-1952). Pero éste hizo un viraje ideológico hacia posiciones más conservadoras, persiguiendo e ilegalizando al comunismo en julio de 1948 y marginando abiertamente la participación de Caffarena y Heredia del proceso legislativo que diera sanción al voto femenino.

Como en las otras instancias analizadas hasta aquí, la extensión de los derechos políticos a las mujeres fue convergente con discursos sobre la familia como institución normativa. Según el testimonio de Rosa Markmann de González Videla, en ocasión de la celebración del Día Internacional Mujer de 1947,

la mujer chilena esta despertando de este estado de resignación en que ha vivido y reclama sus derechos (...) participar en las elecciones no sólo es un derecho sino también un deber cívico, por muy poco que se interesa alguien en política es imposible que se muestre indiferente a la suerte de su patria, porque de ella depende la suerte de su familia y de su propia persona" (en "Homenaje en memoria de Rosa 
Markmann Reijer viuda de GonzálezVidela (en Diario de Sesiones de la Cámara de Diputados, 1 de julio de 2009; el subrayado es mío).

Rosa Markmann presidió la Oficina de la Mujer, creada por entonces, y fue una inspiradora e instigadora del voto femenino ante su esposo.

El sufragio femenino se aprobó en medio de una profunda crisis política, que la Ley de Defensa Permanente de la Democracia, por la cual se había declarado ilegal al Partido Comunista, había encendido, pero también fue un "logro del movimiento feminista" (Rojas Mira 2011: 400).

La ruta de América Latina hacia el sufragio femenino se concreta en Argentina y Chile en los años cuarenta, como acabo de señalar. Pero no fueron los únicos países. La República Dominicana, Guatemala, Panamá, Venezuela y Costa Rica completan la lista. El mismo proceso se dio en Francia, Italia, Albania, Bulgaria, Yugoslavia, Bélgica.Y ello fue así porque las rutas hacia el sufragio universal en ambos lados del Atlántico tuvieron una misma historicidad. Como afirma Therborn, la modernidad, o mejor dicho, la modernización que conduce a ella, es un "cambio epocal” de carácter "global”.

\section{Conclusiones}

Desde las independencias, los cuatro países aquí analizados atravesaron un "largo siglo de democratización". Si en Chile, la iniciativa de universalización del sufragio con sufragio femenino correspondió a las fuerzas conservadoras, en los otros tres casos esa iniciativa estuvo encabezada por fuerzas liberales. En ningún caso se alcanzó la sanción del voto femenino y el argumento para la exclusión fue recurrente: la obligación de las mujeres de atender el hogar.

Como se ha dicho al comienzo, Therborn identifica sucesivas "olas" más allá del "largo siglo". La primera se ubica en los años cuarenta, con la derrota del fascismo y la victoria de los aliados en la Segunda Guerra Mundial, cuando se redemocratizó parte de Europa Central y Finlandia, y cuando las mujeres accedieron al voto en Bélgica, Francia e Italia. Del análisis de los casos latinoamericanos aquí considerados se desprende cierta sincronía con el despliegue de los procesos europeos. Al largo siglo xIx, le siguieron las democratizaciones de los años cuarenta. Como se ha dicho, si bien en Brasil y Uruguay las leyes de sufragio femenino datan de 1932, el ejercicio de ese derecho se vio potenciado por la democratización de los años cuarenta en ambos casos. En Argentina y Chile las leyes datan de esos años. Aunque en el caso de Chile 
es discutible el carácter democrático de un gobierno que ilegaliza y persigue al adversario (en este caso el comunismo), lo cierto es que González Videla apeló a la ampliación de la democracia como instrumento legitimador. ${ }^{13}$

La segunda "ola" democratizadora que Therborn identifica corresponde a los años setenta, situada en Grecia, Portugal y España, cuando se inició un proceso de democratización, y cuando las mujeres accedieron al voto en Suiza (en el nivel nacional).Y la tercera corresponde a la caída de los regímenes de partido único de los países comunistas de Europa del Este, en 1989-1991. Según Therborn, la democratización de Europa del Este significó que el comunismo como vehículo de la modernidad socioeconómica se había agotado. A esta "ola" habría que agregar las leyes de paridad (en Francia, 1999).

Respecto de América Latina, aunque no ha sido objeto de análisis en este capítulo, cabe añadir que en los años de la segunda "ola" democratizadora se eliminó la cláusula de restricción del voto por analfabetismo en Chile. Esto ocurrió bajo el gobierno de Salvador Allende, aunque hay que decir que el golpe y la "exitosa" institucionalización de la dictadura personalizada en el general Augusto Pinochet pronto significaron una grave amputación de la ciudadanía.

En los años noventa, que corresponden a la tercera de las "olas" señaladas por Therborn, se eliminó la cláusula de restricción del voto por analfabetismo en Brasil. Esto ocurrió con la sanción de la Constitución de 1988, durante la fase del primer gobierno democrático de transición. Asimismo, se sancionaron las denominadas leyes de cuotas, en Argentina (Ley n $\left.{ }^{\circ} 24.012\right)$ en 1991 y en Brasil (Ley no 9.504) en 1997.

El análisis muestra que la ciudadanía política se puede descomponer en diversos elementos. Ellos son: quién es el sujeto de ese derecho (exclusiones de género y alfabetismo, señaladas en este capítulo, pero también étnicas y de clase que no han sido consideradas en el análisis); si es, en efecto, un derecho o un derecho/obligación (voto obligatorio o voluntario); si atañe a todos los niveles de la representación o sólo a algunos (municipal, provincial/estadual/ departamental y nacional); y, vinculado a esto, si se instituye en el marco de un régimen federal o centralista.

Por último, cabe recapitular sobre una cuestión que vertebró el análisis: se legisló sobre derechos políticos sin modificar el estatus de ciudadanía civil. En cada una de las instancias analizadas, la imbricación del voto con la emancipa-

13 Therborn (1992: 69) señala que Louis Bonaparte "reinstalled universal male suffrage and used it to legitimate his coup. From then on, the suffrage proved to be of use as an instrument of power and rule, and not only as a popular, egalitarian source of power". 
ción civil estuvo sobre el tapete, tanto para ahondar en el sentido "individual" de la "universalidad" como para limitar la reforma. Así, en términos generales, el proceso de construcción de la democracia y la ciudadanía (incluso en la "ruta pionera") fue conflictivo, tuvo asincronías, discontinuidades, acumulaciones y desacumulaciones. ${ }^{14}$

14 Lobato (1997) se ocupa de esto en relación con los derechos sociales en Argentina; y Giordano (2012), en relación con los derechos civiles en el Cono Sur. De modo más elíptico, preocupada por la "minúscula" cantidad de mujeres representantes en la Asamblea Nacional francesa, Scott (1996: 169 y 170) sostiene que el voto femenino en 1944 no acabó con el estatus de "segundo sexo" y que las mujeres siguieron siendo consideradas como "miembros de familias" sin "libertad económica", subordinadas al varón. 


\title{
IDENTIDADES, CIUDADANÍA Y ETNICIDAD. PERSPECTIVAS HISTÓRICAS
}

\author{
María E. Argeri
}

\begin{abstract}
Al iniciarse el siglo XXI una nueva historia se está escribiendo en relación con la ciudadanía, la etnicidad y los descendientes de los indígenas derrotados en tiempos de la colonia española y en el primer siglo independiente. En este presente, la recuperación de relatos sobre los pueblos ancestrales americanos, la ubicación de sus restos en museos y enterramientos lejos de sus tierras originales, permiten mostrar la cara oculta del proyecto unificador expresado en la consolidación del Estado y la nación homogénea, tal como exigía la doctrina de moda en el siglo XIx, justificando así el poder efectivo de hecho y derecho sobre un territorio y sobre la totalidad de su población. Hoy los discursos y las sensibilidades han cambiado, los sujetos comienzan a ser definidos y a autodefinirse por la identidad. Este concepto, en el siglo XIX, no tenía sustento histórico, porque las lecturas de la realidad eran otras, relacionadas con lo político -en tanto dominio efectivo- y con lo jurídico -definido por la constitucionalidad, la codificación y la igualdad ante la ley-. Ese esquema de poder se sostenía por una concepción militar que incorporaba el conjunto de los varones a la instrucción y la defensa - no ya como milicianos, sino como soldados de unas fuerzas profesionalizadas- según los nuevos parámetros que había impuesto el ciclo revolucionario, modelador del Estado burgués de alcance nacional.
\end{abstract}


Por ello, en el siglo xix, las comunidades indígenas que no aceptaban el orden del Estado y se mantenían bajo mandos naturales eran identificadas como un problema geopolítico y un impedimento para el progreso. Ser ciudadano no es una esencia sino una condición de existencia en un tiempo, unas relaciones sociales y unos sentidos, que hicieron de los indígenas enemigos, rebeldes, aliados, amigos, matreros, cuatreros, soldados, compañeros, trabajadores, comparsas partidarias; electores, punteros políticos, etcétera; también comunidades, colectivo de mano de obra disponible o individuos. Para mostrar este recorrido, trazaremos un círculo que espeje los contrastes entre las actuales reivindicaciones étnicas y los presupuestos más sobresalientes de aquella unificación política decimonónica que se prolongó durante la primera mitad del siglo $\mathrm{xx}$, aunque con sus transformaciones significativas. Describiremos en primer lugar un hito importante como fue, hace once años, la repatriación de los restos del cacique ranquel Mariano Rosas a su tierra de Leuvucó. Su vida sintetiza buena parte de las relaciones entre poderes indígenas y blancos durante la segunda mitad del siglo XIX. Su muerte en medio de la guerra de conquista - debida a la viruela- y la posterior exposición de sus restos al público, clarifica la perspectiva del pensamiento naturalista decimonónico que hizo de los pueblos indígenas piezas de museo (Quijada 1997: 21-46). La repatriación en el inicio del siglo Xxi a la tierra del cacicazgo refleja ya otro país imbuido de la sensibilidad por los derechos humanos. Para conectar ambos momento, sintetizaremos los rasgos más sobresalientes de lo que fue el proceso de incorporación de los derrotados al Estado nacional después de la conquista definitiva, el paso de cacicazgos a la ciudadanía y la vecindad durante el Estado liberal y el peronismo, para destacar finalmente la aparición de una nueva dirigencia étnica -que hoy realiza el camino inverso del individuo a la comunidad-abocada a la tarea reivindicativa, al reconocimiento de derechos y a la organización de pueblos originarios.

\section{EL RETORNO DE LOS ANCESTROS}

Una fría mañana del invierno austral, coincidiendo con el año nuevo mapuche -el winoy tripantu-, el 24 de junio del año 2001, los restos del cacique ranquel Panghitruz Guor-Zorro Cazador de Pumas- fallecido en 1877 fueron inhumados en su tierra de Leuvucó, en la provincia de La Pampa. Un pequeño mausoleo construido en madera de caldén guardará desde entonces en más sus restos. El cacique había nacido alrededor de 1825 a orillas de la 
laguna Leuvucó. Fue el segundo hijo del cacique Painé Guor -Zorro Celeste-. Siendo pequeño fue tomado prisionero, junto a otros compañeros, por una partida militar en las cercanías de Melincué. Los jóvenes ranqueles fueron trasladados a Santos Lugares donde se encontraba la prisión porteña más importante durante el régimen del brigadier general Juan Manuel de Rosas. Como Panghitruz era hijo de cacique fue bautizado con el apellido del gobernador porteño, quien lo apadrinó y le puso por nombre Mariano. Luego de pasar un par de años prisionero se fugó para regresar a su tierra. Cuenta el coronel Lucio Mansilla -en su célebre obra Una excursión a los indios ranqueles (1993: 214) - que Juan Manuel de Rosas, al enterarse de la fuga, envió un regalo a su ahijado consistente en un par de caballadas de un pelo, ganado vacuno y prendas de plata y tejidos, a lo que se agregaba un uniforme de coronel y muchas cintas punzó, distintivo del partido federal. En 1858 Mariano Rosas asumió el cacicazgo de los Zorros, no por herencia sino por aclamación de pares. Durante su gobierno, de casi veinte años, se destacó por el mantenimiento de la paz entre pueblos indígenas y por favorecer el refugio de los unitarios que el régimen rosista condenaba a muerte o al destierro. El 18 de agosto de 1877 falleció de viruela en los momentos en que la conquista comenzaba su etapa más cruel. Asumirá entonces el cargo su hermano Epumer, el tercer hijo de Zorro Celeste. En 1879, cuando la etapa final de la Campaña del Desierto asolaba la llanura pampeana, la columna militar perteneciente a la tercera división comandada por el coronel Eduardo Racedo descubrió en Leuvucó la tumba del cacique. Los huesos, que en un primer momento estaban destinados a la Sociedad Antropológica de Berlín, fueron posteriormente donados a Estanislao Cevallos, que a fines del ochocientos los remitió al Museo de Ciencias Naturales "Florentino Ameghino" de la ciudad de La Plata. Una vez en el museo, el cráneo del cacique Panghitruz Guor fue catalogado con el número 292 y expuesto en las vitrinas durante más de un siglo.

En la década de 1980 y con el retorno de la democracia, los ranqueles comenzaron a reclamar los restos del cacique, siendo sus gestiones ante las autoridades del museo etnográfico avaladas por los sucesivos gobiernos provinciales. Finalmente, por la ley n ${ }^{\circ} 25.276$, el poder ejecutivo nacional, a través del Instituto de Asuntos Indígenas, procedió a la devolución de los huesos a los descendientes del linaje. La urna fue recibida por su sobrino tataranieto, Alfredo Domínguez Rosas, quien acompañado de dieciocho jefes ranqueles viajó hasta La Plata. De allí fueron trasladados a la provincia pampeana y la inhumación se realizó en territorio ranquel. Los restos envueltos en la bandera de la nación rankulche -roja, verde y azul- fueron velados en el salón 
municipal del pueblo deVictorica. El homenaje se completó con los discursos del gobernador Rubén Marín y de otras autoridades locales, realizándose posteriormente al amanecer una ceremonia religiosa mapuche en el momento que la urna era depositada en el mausoleo, desde ese momento convertido en lugar sagrado para los pueblos indígenas (Clarín 2001: 1). La rogativa se inició con el primer rayo de Sol al sonar la trutruka. Los varones, vestidos con ponchos e indumentaria indígena, formaron una hilera mirando al naciente, mientras detrás se ubicaban las mujeres engalanadas de igual manera. Los caciques principales rogaron en lengua mapudungum a Ngenechén -el Dios de la Gente-. Luego de realizar los ritos masculinos siguió el turno de las mujeres. Al finalizar la ceremonia, el cacique Canoé exhorto a su pueblo recordando el momento histórico que estaban viviendo, un siglo después de la definitiva conquista.

\section{ORGANIZACIÓN NACIONAL}

En los niveles doctrinarios y filosóficos, la organización política republicana aceptará un único contrato que afectará al conjunto de la nación; en el momento que se ponía en acto el denominado poder constituyente originario (Clavero 1997). Ese instante eminentemente constitucional igualaba a todos los habitantes nacidos en el territorio como un único pueblo y, por tanto, como una única soberanía. Pero las negociaciones que finalizarían en la promulgación de la Constitución, umbral del Estado moderno, fueron llevadas adelante por diputados que o bien habían nacido en el contexto colonial o en un espacio todavía muy fuertemente influido por las concepciones políticas españolas, que hacían de la vecindad y la soberanía de los pueblos el eje del basamento constitutivo de los pactos con la monarquía. Entonces, no fue sencillo cambiar una concepción plural por otra singular, en la medida que era necesario solapar los conceptos jurídicos (Guerra 1999: 33). Resultado de esos debates y negociaciones fue, por un lado, la creación de un legislativo bicameral -con una cámara de senadores que representaba a los pueblos de las provincias y una cámara de diputados que representaba a la totalidad de la nación- y, por otro, la partición constitucional entre provincias y territorio nacionales. Estas últimas regiones eran tuteladas por el presidente, en su carácter de comandante en jefe; sitios además donde la experiencia política y la cohesión social propias de la vecindad debían desarrollarse como instancias previas a lograr estatuto provincial. 
A fines del siglo XIX se había producido asimismo una modificación en la concepción singular de pueblo. La influencia del pensamiento francés y dentro de él, el de la Tercera República, conducía a revestir de nuevo ropaje a la ciudadanía y a los súbditos, para que de ellos emergiera el ciudadano y la nación no ya con cariz revolucionario, militante y en armas, sino en tono reposado, aburguesado y dominado por la idea de progreso. Ambos conceptos presuponían una abstracción que no tenían ni la noción de vecino ni la de súbdito. En el sistema español los pueblos reactualizaban su vinculación con la monarquía según las tradiciones jurídicas que habían hecho del fuero y los privilegios el marco legal dominante en todos los reinos, tanto de los propiamente ibéricos como de los americanos; pactos muy alejados del sentido de la voluntad general. En esta mutación de vecinos a ciudadanos y de súbditos a colectivo nacional medió también una fuerte transformación del pensamiento científico en el que abrevará la legitimación política. Siguiendo la tónica del siglo xix el individualismo filosófico era todavía objeto de debate en círculos intelectuales más o menos cerrados; mientras la idea de colectivo orgánico - no ya jurídico como el de las vecindades- continuaba muy claramente la vertiente spenceriana y había logrado gran difusión entre públicos muy diversos. En efecto, hacia la segunda mitad del ochocientos los pueblos eran concebidos como naciones, pero no ya como colectivos asentados en el nivel solamente jurídico y cívico del comportamiento político al estilo revolucionario francés, sino antes bien como un colectivo cultural, pero con una fuerte impronta organicista, que con el devenir de las décadas y al compás de los conflictos por la ocupación imperialista y las alianzas que se iban entretejiendo en la Europa finisecular iban a perfilar claramente la idea nacional como colectivo homogéneo, ya fuese asentado sobre la idea de raza o sobre la diferencia cultural. Por una u otra vertiente las naciones comenzaron a concebirse como conjuntos compactos, sin fisura, homogéneos (Quijada/Bernard/Schneider 2004). Lejos estaba para ese entonces la primera concepción nacional sustentada en la voluntad política y la ciudadanía en armas (Sabato/Lettieri 2003) que había caracterizado a la primera revolución francesa, la de 1789, y que había sido difundida por el impulso de las conquistas y victorias napoleónicas a lo largo y ancho de Europa y del Mediterráneo. El civismo había dado paso a la homogeneidad y esa homogeneidad siempre imaginaria podía o no concebirse sustentada en la raza. Pero la vertiente racista, que dentro del universo de posibilidades intelectuales decimonónicas logró un estatuto central, no sostuvo la creación de la nación argentina, a pesar de que existiesen bolsones intelectuales racistas o un pen- 
samiento prejuicioso a nivel de los diferentes sectores que conformaban el pueblo argentino. Contrariamente, la homogeneidad nacional en Argentina se construyó a partir de la educación primaria obligatoria y común, la igualdad ante la ley, las obligaciones de hacer el servicio militar, votar y pagar las cargas públicas (Chiaramonte 1997).

En este sentido cabe destacar que en los últimos tiempos se están haciendo esfuerzos investigativos e interpretativos para comprender que han sido los mismos procesos históricos los que afectaron tanto a criollos, inmigrantes, indígenas y afrodescendientes. Y esto es así a pesar de los prejuicios, de los racismos propios del siglo $\mathrm{xx}$ y de las miradas que emergieron de la corriente del autodenominado revisionismo histórico. Lo hemos dicho en otros trabajos: a los indígenas se les ha reservado la mirada antropológica y se les ha desprovisto de análisis sociológicos, políticos, económicos. Fue recién en las últimas tres décadas cuando han alcanzado relevancia historiográfica y en los últimos años han sido insertos en el relato de la construcción nacional. En este sentido, la corriente revisionista -cuya importancia no está en los espacios académicos, pero sí en la difusión que ha tenido gracias a las militancias de derechas primero y de izquierdas después- adolece de varios problemas analíticos primero e interpretativos después, en especial tres. En primer lugar, no comprende el significado de las conquistas sobre los pueblos indígenas, especialmente las últimas, que se dirigieron hacia el sur y el nordeste. En segundo, lugar asocia la guerra con el racismo, cuando en realidad se trataba de una cuestión de política militar en la consolidación de la territorialidad propia de los Estados nacionales. Finalmente, supone que los indígenas fueron ciudadanos de menor categoría, confundiendo racismo con jerarquías territoriales a la hora de ejercer los derechos políticos. Esta última mirada fue después ampliamente expandida por diferentes textos antropológicos, que confiaron en aquella historiografia, tan poco afecta a miradas analíticas y a la búsqueda de documentos y trabajo en archivo. En efecto, esas confusiones se originaron en la incomprensión o la toma a la ligera de lo que fue una división de carácter jurídico constitucional, que dividió el territorio nacional en dos espacios: las provincias y los territorios nacionales. De acuerdo con la Constitución, al finalizar el siglo XIX, nuestro país estaba dividido catorce provincias y los siguientes territorios nacionales: Misiones, Chaco, Formosa, Los Andes, La Pampa Central, Neuquén, Río Negro, Chubut, Santa Cruz, Tierra del Fuego e islas del Atlántico Sur. Esta división no es un dato menor, sino el eje que permite comprender la participación política y la construcción ciudadana. 
De LA COMUNIDAD AL INDIVIDUO

Los estudios historiográficos y antropológicos que han colocado a los indígenas en el centro de la escena histórica han rivalizado entre dos interpretaciones antagónicas. Una sostiene el estatuto disminuido de los indígenas frente a la ciudadanía y los derechos políticos. La otra remarca que existió igualdad jurídica en el ejercicio de los derechos civiles y políticos, reconociendo que las diferencias no se debieron a la legalidad, sino a la dominación de clase. El desencuentro entre ambas posturas se debe, entre otras circunstancia, a los archivos consultados y al sitio en el que cada investigador se sitúa para mirar un proceso histórico en general. Por ello no es lo mismo mirar a la Argentina desde una provincia que desde un territorio nacional. La división constitucional, que concedió estatuto diferencial grosso modo a la mitad geográfica del país, es una pieza clave para comprender cómo se incorporaron los indígenas y desarrolló la ciudadanía política (Argeri 2005). En Argentina existió una tendencia igualitaria a la hora de ejercer los derechos de voto, formar parte de colectivos electorales y hasta hacer fraude electoral, tal como es posible observar en las sociedades provinciales. Esa misma tendencia igualitaria se mantuvo en los territorios nacionales, espacios en que la ciudadanía se encontraba adscripta a la vecindad, y así era para todos los varones sin importar antecedentes étnicos. Por ello, respecto de los derechos políticos es necesario destacar que los indígenas fueron considerados ciudadanos argentinos desde la Asamblea del Año XIII, por aplicación del ius solis. Todos los nacidos en el suelo de la patria eran argentinos en igualdad de condiciones, de obligaciones y de derechos. El nacional y el ciudadano tendían a unirse estrechamente, mientras que la vecindad contemplaba también a los extranjeros.

En cuanto al plano militar y a las incorporaciones forzadas o consensuadas, éstas siempre estuvieron mediadas por derrotas, capitulaciones o acuerdos pacíficos, así como por un sinnúmero de interacciones de tipo económico, político y militar (Quijada 2011). En efecto, en el largo derrotero que se inicia con la independencia y las luchas civiles, un buen número de indígenas con sus caciques a la cabeza fueron incorporándose poco a poco a vivir dentro de las fronteras, solicitando tierras en los fuertes y también participando en los batallones que confrontaban por dirimir la forma de organización nacional según esquemas unitarios y federales. En ambos bandos era posible encontrar batallones de los denominados "indios amigos", que desempeñaban un papel importante no sólo en la política criolla, sino también con los caciques que comandaban las jefaturas indígenas independientes, así como también en las 
alianzas más permanentes o más circunstanciales entre los caciques, los jefes de frontera y los representantes de la política nacional o provincial (Bechis 2008).

En esos acuerdos de fronteras, los indígenas estaban habituados a dialogar, argumentar, alegar y parlamentar. Tenían entrenamiento fino en la participación política, mucho más que la mayoría de los extranjeros que llegaban al puerto. Pero a pesar de haber existido relaciones muy porosas en las fronteras, prevalecen todavía miradas dicotómicas. Por uno u otro motivos directamente relacionados con énfasis étnicos, socio-étnicos, étnico-raciales o raciales naturalistas, la clave analítica y la configuración de relatos hunden su raíces en la impronta ideológica decimonónica según la dicotomía civilización versus barbarie.

En el siglo XIX la tónica era pronunciarse por la civilización -categoría idéntica a cultura urbana, política citadina según la polis o la civitas-; hacer de los muchos, el uno -e pluribus unum, o sea, consolidar el Estado-; configurar la nación en base a un principio común de soberanía que conducía a normar el espacio geográfico -ya ocupado, fuese de hecho o por derecho- con límites definidos; desarrollar derecho interno nunca subordinado al derecho internacional; además de una vocación de autarquía económica que permitirá ponderar, desde fines del ochocientos y hasta bien avanzada la segunda mitad del siglo xx, como el logro más revelador del éxito de unos estados frente a otros que nunca supieron negociar con empresas extranjeras y se dejaron comandar no sólo en los aspectos económico, sino fundamentalmente en las matrices políticas, perdiendo capacidad para autodeterminarse. Sobre este esquema histórico después de la independencia y sobre todo después de seis décadas de luchas civiles emergió una forma Estado que desconocería tanto las comunidades étnicas como los colectivos de vecinos. En este marco es donde la construcción ciudadana de tipo moderno, anclada en el individuo, alcanza su razón de existencia y al mismo tiempo la conformación de nuevos sujetos políticos (Chust 2004). Por tanto, en el ochocientos la estatalidad tuvo que desandar los siglos coloniales y hacer de los vecinos, los ciudadanos. Ese derrotero iba de la mano de una inseparable concepción de modernidad y modernización, para finalizar con antiguas estructuras que había plasmado lo político mediante la reiteración constante de pactos entre la monarquía y los pueblos, en plural. Pactos que en el caso de las sociedades indígenas se forjaban en los Parlamentos, cuando la Corona reconocía a esas "naciones" como integrantes del Reino de España; documentos que hoy son tomados por los descendientes como fehaciente prueba de su soberanía perdida.

El paso de la comunidad al individuo no fue sencillo para las sociedades indígenas, y mucho menos lo fue para los últimos cacicazgos conquistados a 
fines del siglo XIX para la región sur y a principios del $\mathrm{xx}$ en el nordeste del país. En ambos caso la residencia en territorios nacionales hizo prevalecer la vida comunitaria -a pesar de haber perdido su propia capacidad militar-, generalmente cohesionada por los jefes familiares, quienes eran los intermediarios entre sus parientes y agregados con los estancieros, los jefes militares y diferentes administradores y agentes del Estado (Argeri 2011). En otros casos, los menos, las familias se agrupaban en poblados y si éstos alcanzaban el estatuto municipal, los indígenas ejercían derechos políticos propios de la vecindad, en igualdad de condiciones con otros argentinos y también con los extranjeros residentes. El principio político de la vecindad no era nacional, sino territorial, de allí que los inmigrantes podían elegir y ser elegidos en los municipios de los territorios nacionales.

Por tanto, votar o no votar en los territorios nacionales no se relacionaba con la nacionalidad y tampoco con la condición étnica, porque no era la nacionalidad la determinante de la ciudadanía, sino la residencia. Al estar el Estado argentino dividido en dos estatutos constitucionales, en las provincias la ciudadanía era determinada por la nacionalidad de origen -o en su defecto por la naturalización- y en los territorios nacionales, los derechos políticos eran restringidos a la condición de vecinos residentes. Ahora bien, esa restricción en el ejercicio del voto no implicaba ausencia de vinculaciones política entre indígenas, y entre éstos y el resto de los habitantes de los territorios nacionales. Como ya destacamos, la pervivencia de la vida comunitaria hizo perdurar los estilos políticos propios de los cacicazgos. Respecto de la entrega de tierras para avecindamiento en los territorios nacionales existieron dos modalidades. La primera de ella fue a los caciques derrotados, concedida mediante ley del Congreso nacional, y entregadas después de la capitulación. La segunda forma fue gracias a la intervención del Departamento de Tierras y Colonias. En este último caso ya no se trataba de caciques derrotados, sino de indígenas jefes de familia que debían inscribirse ya fuese como ocupantes precarios o arrendatarios, con o sin opción a compras, mediante pago de canon; también con posibilidad de transferir derechos a los cónyuges, descendientes $\mathrm{y}$ ascendientes.

Por su parte, aquellos indígenas que permanecieron en las provincias siguieron un camino de adaptación que implicó mucho ir y venir entre capitulaciones de las comunidades, pactos, acuerdos, rebeliones y aceptación pacífica a lo largo de los siglos coloniales y del siglo xIX. En líneas generales, después de la independencia, en todas las provincias se siguió la modalidad impulsada por la colonia española, incorporándolos a las milicias, entregando cuotas de 
ganado y asentándolos en poblados para avecindarlos mediante la entrega de tierras de labranza y solares (Quijada 2011). En virtud de la homogeneización de toda la población, los indígenas estuvieron sujetos al mismo derecho y leyes que cualquier otro ciudadano argentino; debiendo escolarizar a la prole; realizar el servicio militar y votar en las elecciones. En este último caso la participación electoral estuvo definida por la libertad u obligatoriedad, según las leyes de cada momento. Por tanto, no existieron impedimentos legales para ejercer la representación, aunque las dificultades en el ejercicio real de los derechos políticos se relacionaron directamente con vínculos de subordinación de clase a las oligarquías y élites provinciales, capaces de utilizar diversos mecanismos materiales -como la sustracción de los documentos; la represión y la pérdida de oportunidades laborales- hasta simbólicos, como por ejemplo la difusión de imaginarios portadores de miedos y castigos, cuyo efecto era que las clases más pobres se alejaran de las urnas. Estas barreras sociales fueron un poco morigeradas en el momento que la ley electoral cambia, utilizando el padrón militar y el voto secreto a partir de 1912. En ese momento los partidos mutaron estrategias y comenzaron la propaganda y las campañas electorales, con asado criollo, prendas en dinero y beneficios a los punteros políticos. Esta nueva realidad abarcaba a todos los varones nacionales sin importar el origen étnico de sus padres. Es decir, todos tenían por igual la capacidad de asociarse políticamente, afiliarse libremente a los partidos, convertirse en punteros, etcétera. Pero, como enunciamos más arriba, esta capacidad ciudadana encontraba en los espacios provinciales un límite dificil de franquear: la subordinación de clase. De allí que la historia de la ciudadanía sea diferente según existiera una más fuerte o más débil oligarquía provincial.

La combinación entre oligarquías provinciales, legislación liberal y proyecto nacional sostenido por una economía de exportación con fuerte vinculación hacia las empresas extranjeras se verá trastocada con el arribo del peronismo al poder. Con el gobierno de facto que se instala en 1943, Juan D. Perón se hace cargo de la secretaría de Trabajo y Previsión, creándose allí la Dirección General del Aborigen a cargo de Ángel Saturnino Taboada, desarrollando una política social y económicamente compensatoria de los muchos abusos sufridos desde la derrota, y como una acción tendente al desarrollo de la justicia social, a lo cual se sumaba el Estatuto del Peón de Campo en 1944 y los derechos sociales expresado en la Constitución de 1949 -tres años después de que Perón asumiera la presidencia logrando mayoría de votos-. A la Secretaría de Trabajo y Previsión llegaban las solicitudes que remitían los delegados indígenas locales, quienes desempeñaban el cargo de manera 
honoraria (Argeri 2011). Pero los beneficios que concedió el peronismo no afectaron a todas las comunidades indígenas por igual (Íñigo Carrera 1983), favoreciendo muy claramente a las comunidades de los territorios nacionales del sur del país, cuyos caciques y delegados pudieron mantener una fluida vinculación con el gobierno nacional, en la medida en que de esas alianzas no dependían los resultados electorales posteriores que afectaran la composición del Congreso nacional. Los vínculos políticos tenso del gobierno peronista con los grupos dominantes en los territorios no tenían impacto interno determinante. De modo que favorecer a las familias indígenas y a los pobres en general significó un amplio beneficio sin costos graves. En cambio, el vínculo entre Perón y las comunidades del noroeste que habitaban espacios provinciales se vio afectada por otro tipo de relaciones políticas, en el que las oligarquías provinciales hacían valer su peso, sobre todo en el Senado. De allí que a partir del año 1943 y sobre todo después de que Perón es electo presidente en 1946, la estrategia peronista en el interior quedará adscripta a los pasos que pudiera dar la Confederación General del Trabajo en el armado y organización de fuerzas sindicales. De modo tal que no se comprometiera abiertamente la cara del Estado y pudiera jaquearse el poder de las oligarquías desde la base social.

En el caso de los territorios nacionales para llevar a cabo sus políticas públicas y sociales, la Secretaría de Trabajo y Previsión nombro jueces de paz nacionales -que iban con la misión de romper las alianzas de la antigua justicia de paz con hacendados y comerciantes importantes- y delegados indígenas con atribuciones similares a las que tenían los delegados obreros de fábrica. $\mathrm{Y}$ si los jueces de paz nacionales no tenían vinculaciones con el medio, ya que eran funcionarios que iban desde Buenos Aires, los delegados indígenas eran generalmente caciques o miembros de la familia de los caciques. Estos últimos se convirtieron en punteros de la política peronista, y conectaban las demandas de sus comunidades tanto con las autoridades regionales como con las instancias nacionales, favoreciendo que la gran presión capitalista y, sobre todo, del capital mercantil usurero dejara de ejercerse sobre los campesinos y peones. Así se suspendieron juicios por deudas de almacén y cobro de pesos, como también se congelaron los cánones de arrendamiento de la tierra y se favoreció la venta de la tierra fiscal en pequeñas parcelas, tanto en las áreas rurales como urbanas. Analizando la política peronista se observa que el derrotero seguido por las comunidades indígenas no fue, como se supone, de exclusión y marginación desde las campañas militares del siglo XIX al presente, sino que hubo momentos diferentes, en relación con las políticas públicas, los partidos gobernantes y las respuestas que los líderes étnicos supieron dar 
en cada momento. En los últimos tiempos del segundo gobierno peronista y después de su derrota en 1955, los territorios nacionales cambiaran su condición y se les reconocerá rango provincial, pudiendo votar en los tres niveles: municipal, provincial y nacional.

Los golpes militares que intentaron dar por tierra con la organización y las instituciones del Estado peronista cancelarán toda política hacia los indígenas. Producida la Revolución Libertadora, el general Aramburu suprime la Dirección de General del Aborigen. Entre 1955 y 1980, la preocupación por los pueblos originarios será solamente provincial en aquellos casos donde los poderes regionales entendían que debían hacerse cargo de los problemas sociales de los indígenas, quienes por regla general siempre forman parte de los sectores más indigentes de la población nacional. Finalizado el Proceso en 1983, se inicia otro momento en el que se destaca la labor de la una nueva dirigencia étnica invocando la reinvención de la tradición originaria. Ella trabajará por el reconocimiento de derechos a los pueblos autóctonos, posibilitando que muchas comunidades que existían de hecho en el territorio nacional se cohesionen en búsqueda de la personería jurídica, mientras otras que habían dejado de existir comenzarán un proceso de reorganización.

\section{DE INDIVIDUO A COMUNIDAD}

El camino hacia la conformación de las nuevas comunidades autodenominadas "pueblos originarios" data de hace alrededor de treinta años, y se vincula muy estrechamente con los principios filosóficos y jurídicos de los derechos humanos. Una problemática que dará por resultado la institucionalización de organismos y asociaciones especializadas tanto en la búsqueda de personas desaparecidas y en el establecimiento de la verdad como así también en la recuperación y mantenimiento de la memoria histórica. Desde entonces en más, los funcionarios de las instituciones estatales y los dirigentes de partidos políticos ya no podrán desconocer en sus programas de gobierno esos derechos inalienables para el ejercicio de una vida en democracia. La reforma constitucional de 1994 dará rango constitucional a once tratados internacionales sobre el tema, destacándose, entre ellos, la Declaración Universal de los Derechos Humanos y la Convención Americana sobre Derechos Humanos, conocida como Pacto de San José de Costa Rica. Pero la incorporación de estos instrumentos de derecho internacional tendrá sus consecuencias tanto para la recepción de los derechos indígenas como para estipular las obliga- 
ciones y competencias del Estado respecto de los argentinos pertenecientes a pueblos originarios.

Cierto es que la reforma argentina reconoce derechos a los pueblos indígenas, aunque subordinados a las leyes y nunca por encima de ellas y preexistentes al Estado. Más aún, en la Constitución, el texto que se refiere al "reconocimiento" no está incluido como derechos y garantías sino como atribución del Congreso para legislar en consecuencia. Ahora bien, el artículo 75 constituye en sí mismo, para el marco jurídico general que provenía del siglo XIX, una fuerte anomalía, al permitir la adopción de una concepción algo más plural en perjuicio de las convenciones decimonónicas que sostuvieron a rajatabla la propiedad individual y la definición de una nación homogénea. Cuando en 1994 se reunió en la ciudad de Santa Fe la Convención Constituyente, los convencionales debatieron ampliamente el artículo que intentaba, en alguna medida, reparar las acciones del pasado y si bien en un primer momento la comisión que trató el tema -integrada por el Frente País Solidario, el Partido Radical y el Partido Justicialista- había decidido declarar a los pueblos indígenas como "constitutivos de la nación Argentina", posteriormente sin que quedara documentado el motivo, la Comisión de redacción decidió anular esa expresión y darle al párrafo correspondiente al tema indígena nueva redacción y una nueva ubicación, colocándolo en el capítulo de las atribuciones del Congreso y desoyendo el reclamo de las comunidades que habían pedido que formara parte del capítulo "Nuevos derechos y garantías".

Existen antecedentes jurídicos y políticos que convergen en 1994. Respecto de los primeros hay que destacar la promulgación de la ley $n^{\circ} 23.302$ sobre Política Indígena y Apoyo a las Comunidades Aborígenes, aprobada en 1985 y reglamentada en 1989 (Tanzi 2000). Era una ley de fomento que se proponía como objetivos la atención y el apoyo de las comunidades, respetando al mismo tiempo sus propios valores. Para conceder la personería jurídica era suficiente la presentación de conjuntos familiares, de tres o más familias, que se reconociesen como tales. Este requisito era primordial si se quería hacer alguna presentación para obtener los títulos de propiedad. Para ello la ley creaba el Instituto Nacional de Asuntos Indígenas, dependiente del Ministerio de Salud y Acción Social. De manera complementaria a la resolución del problema de los títulos de propiedad la ley preveía un plan de salud y un plan educativo. Los estudios realizados sobre deserción escolar muestran un alto valor en relación con los niños indígenas. Por ello, la ley estipulaba dividir la enseñanza primaria en dos ciclos en las áreas de asentamientos indígenas. Los primeros años las clases se dictarían en la lengua materna de los alumnos, 
siendo el idioma castellano una asignatura más. Mientras que en el segundo ciclo de la escuela primaria la enseñanza sería obligatoriamente bilingüe.

Otro de los antecedentes jurídicos fue la adopción, también en 1989, del Convenio n ${ }^{\circ} 169$ de la Organización Internacional del Trabajo -que consagró el derecho de los aborígenes a nivel mundial-, ratificado en 1992 mediante la ley $n^{\circ} 24.071$. En su conjunto, la ley no 23.302 y el decreto $n^{\circ} 169$ obligan al Estado a garantizar el reconocimiento de los valores y las prácticas culturales, religiosas y espirituales de los pueblos aborígenes, tomando en consideración las costumbres y el derecho consuetudinario. La ley $\mathrm{n}^{\circ} 24.309$, que origina la reforma, señala en su artículo tercero "la adecuación de los textos constitucionales a fin de organizar la identidad étnica y cultural de los Pueblos Indígenas". La posibilidad de la reforma hizo que las comunidades aborígenes redactaran más de sesenta proyectos que fueron elevados a la Convención Constituyente. Pero a pesar del debate que se suscitó, el reconocimiento de derechos no se hizo, como ya lo expresáramos, en la sección "Nuevos derechos y garantías", lo que hubiera significado iniciar el camino para intentar en el futuro el reconocimiento de una nación plural. Entonces, del artículo $\mathrm{n}^{\circ} 75$, inciso 17 , emergen tres cuestiones básicas, además del reconocimiento. Ellas son la aceptación de la educación bilingüe; el reconocimiento de que las comunidades puedan gestionar en el área de recursos naturales y cuidado del medio ambiente; $y$, finalmente, la posibilidad de otorgar la propiedad comunal inalienable de las tierras que se consideran de ocupación tradicional.

Pero esas tierras denominadas tradicionales no son necesariamente las que los linajes ocupaban en algún momento de los siglos pasados, sino aquellas que pudieron ocupar y conservar después de su derrota, ya sea porque no interesaban a otros ocupantes o porque pudieron defenderlas de otros intereses particulares gracias a la utilización de mecanismos legales y políticos. Cierto es que los marcos normativos sirven a el establecimiento de reglas de juego, y en este sentido el artículo $\mathrm{n}^{\circ} 75$, las leyes previas a la reforma-como por ejemplo las $\mathrm{n}^{\circ} 23.302$ y la $24.071-\mathrm{y}$ lo estipulado por algunas Constituciones provinciales ha posibilitado que las comunidades aborígenes adquieran personería jurídica y reclamen sus tierras y la educación bilingüe. La lucha por la retención o el otorgamiento de las tierras comunitarias muestra entramados de poder en los que, para tener algún resultado positivo, es absolutamente indispensable la existencia de una dirigencia indígena que pueda impulsar el proceso de validación de derechos. El signo más destacado de las acciones reivindicativas que llevaron adelante los nuevos movimientos fue el reclamo de la propiedad de las tierras que se mantenían en usufructo o en condición muy precaria de 
explotación desde hacía más de cien años. En este sentido, el reconocimiento comunitario, la defensa de la lengua autóctona y la propiedad comunal conforman los rasgos más sobresalientes de la identidad étnica. Los pueblos originarios no reclaman derechos electorales ni representación, porque es una instancia que se les reconoce a todos los argentinos sin mirar diferencias étnicas. No obstante, en el reacomodamiento de las comunidades, el otorgamiento de personería jurídica y el control de recursos en las áreas afectadas a las comunidades han surgido algunas propuestas más claramente independentistas, frente a otras que se pronuncian por una nación argentina plural.

\section{Colofón}

Como anunciamos en el inicio de este texto, hacer referencia a las prácticas ciudadanas es adentrarse en un universo complejo, en el que las relaciones entre los indígenas y los otros habitantes dependían al menos de tres aspectos relevantes. En primer lugar, la ciudadanía estaba definida por la residencia en una provincia o en un territorio nacional. En segundo lugar, fue decisivo si la comunidad se disolvió o permaneció bajo mandos naturales. En los lazos comunitarios ancestrales, los caciques han desempeñado papeles decisivos para integrar o aislar a la comunidad, según las vinculaciones con las diferentes fuerzas políticas nacionales, regionales y locales. Finalmente, el derrotero de los indígenas tuvo sus diferencias según el Estado desarrollara una política más populista o más liberal. En ese mismo sentido, hacia finales del siglo Xx, después del Proceso, la política de derechos humanos ha tenido una fuerte incidencia en la redefinición de los alcances de la ciudadanía, tanto respecto de la participación como de la representación. Los aspectos positivos de esta apertura vinculados con los derechos humanos condujeron a que muchas comunidades hayan logrado la personería jurídica y el reconocimiento de tierras comunales. De allí que el rasgo más sobresaliente que cierra el círculo que hemos trazado sea la organización de una identidad étnica -gracias a la reintegración de las familias y la recuperación de tradiciones- que sobrepasa las fronteras del país y se reunifica con otros grupos de idéntica tradición allende las fronteras, favoreciendo no ya la consolidación de una nación plural en el marco de los Estados reconocidos, sino de nuevas territorialidades que ponen en cuestionamiento las fronteras. De este modo, autarquía, autodeterminación, lengua y tierra son los pilares sobre los que se levantan la reunificación de los pueblos originarios amparados en la reforma constitucional de 1994. 


\title{
LA CONSTRUCCIÓN HISTÓRICA DE LA CIUDADANÍA SOCIAL EN AR GENTINA. UNA LECTURA DE LARGO PLAZO
}

\author{
Juan Suriano
}

La construcción de la ciudadanía social, como las de la ciudadanía política y civil, no fue un proceso unívoco. Por el contrario hubo momentos en que los debates y las demandas se activaban y otros que, como en la última década del siglo Xx, se produjeron limitaciones ostensibles en los derechos ciudadanos tanto en América como en Europa. Como sucede con las otras formas de ciudadanía, su adquisición no ha sido secuencial y las características que tuvo en diferentes países ha demostrado los grados de complejidad y heterogeneidad implícitos en cada uno de los Estados nacionales.

En Argentina, la sanción del Código Civil en 1869, de la ley de sufragio universal (masculino), obligatorio y secreto en 1912, y el reconocimiento de los derechos sociales durante el gobierno de Perón, formalizados constitucionalmente con la reforma de la Constitución en 1949, puede sugerir un proceso evolutivo tal como había sostenido Marshall. Sin embargo, fue profundamente analizado por una vasta literatura que las mujeres no fueron consideradas en condiciones de igualdad con los varones aunque la Constitución nacional sancionada en 1853 sostenía la igualdad de todos los habitantes sin distinciones de raza, nacionalidades, clases o sexos. Las mujeres tardaron décadas en alcanzar la igualdad jurídica y accedieron a los derechos políticos casi cuarenta años más tarde que los varones (Lobato 1997, 2007, 2008).

El reconocimiento de derechos sociales (derechos al trabajo, la salud, la educación, la seguridad social) de los trabajadores (hombres y mujeres) fue un 
proceso complejo que en numerosas ocasiones dependió de las demandas y las presiones de los propios actores, de las acciones desplegadas por políticos, intelectuales y profesionales provenientes de diversos campos ideológicos y de la intervención estatal. De modo que, aunque a veces consideramos la conquista de algunos derechos sólo desde el momento de la sanción de una ley, su adquisición forma parte de un largo proceso en el que intervienen diferentes agentes e influyen factores distintos como las crisis económicas o el predominio de ideas y valores poco sensibles a resolver los temas cruciales asociados con la "cuestión social".

En algunos momentos la iniciativa sobre la extensión de derechos correspondió al Estado, quien se adelantó a los reclamos de los trabajadores, especialmente en materia de seguridad social, ya sea por temor al conflicto social o por convicciones de las burocracias especializadas en políticas sociales. Responde también a la necesidad de los Estados capitalistas, generalizada durante la segunda posguerra, de moderar las crisis de legitimidad provocadas por el carácter irresoluble entre igualdad jurídica y desigualdad social y económica (Offe 1990). Además, en diversos momentos y con diferentes criterios se incorporaron a la corriente de reforma social y la enriquecieron, intelectuales y profesionales de diverso signo ideológico, funcionarios, periodistas, políticos, organizaciones de la Iglesia e incluso entidades patronales. Se podría decir que la construcción de la ciudadanía social es el producto de una conjunción de factores coyunturales y estructurales y de la intervención de una multiplicidad de actores sociales y políticos.

En Argentina, a lo largo del siglo xx los debates sobre la cuestión social se relacionan con una serie de necesidades insatisfechas en amplios sectores de la población que condujeron a los trabajadores y los sindicatos a reclamar mejores condiciones de trabajo (buenos salarios, jornada laboral de ocho horas, derecho de agremiación); a los vecinos y las sociedades de fomento a demandar obras de mejoramiento urbano; a las mujeres y sus organizaciones a exigir la igualdad de derechos con los hombres; a los desocupados a solicitar el pleno derecho al trabajo. Además, todos requerían el mejoramiento de servicios urbanos, de salud y de educación. El grado de intensidad de estos reclamos varió de acuerdo a las coyunturas económicas y políticas, al clima de ideas imperante, al contexto internacional y a la capacidad de presión de cada sector demandante (sindicatos, entidades territoriales, organizaciones de desocupados). En este texto se analiza el proceso histórico de construcción de los derechos sociales de los trabajadores en Argentina en una perspectiva de largo plazo. Aunque el trabajo es el eje vertebrador de los derechos sociales, 
lo ciertos es que ellos abarcan un conjunto más amplio de cuestiones como la educación y la salud y está atravesado por las diferencias de género y generacionales.

\section{PROTESTA Y REFORMA SOCIAL}

Argentina, como otros países americanos, sufrió agudas transformaciones económicas, políticas, sociales y culturales entre fines del siglo xix y principios del xx. Los indicadores socioeconómicos del período 1869-1914 muestran el aumento de la producción agropecuaria y el comercio de exportación e importación, de las obras de infraestructura (construcciones portuarias y ferroviarias) que favorecían el comercio con los principales centros consumidores europeos, de la población con la llegada de trabajadores provenientes de España e Italia principalmente y de las construcciones públicas y privadas en las grandes ciudades como Buenos Aires.

Si la cara del progreso y del crecimiento era visible, también lo era el clima de malestar social que, a principios del siglo xx, involucraba centralmente a los trabajadores. La gran mayoría de ellos enfrentaba malas condiciones laborales (largas jornadas de trabajo, magros salarios, falta de estabilidad, frecuentes accidentes) y vivía hacinada en viviendas precarias (conventillos, pensiones, ranchos). Con la excepción de la eventual cobertura de alguna sociedad mutual y de la defensa de las organizaciones gremiales que comenzaban a tomar cuerpo, los trabajadores carecían casi por completo de protección por parte del Estado. En este contexto, tanto el anarquismo como el socialismo (y más tarde el sindicalismo revolucionario) arraigaron con solidez en el mundo obrero y fueron quienes orientaron sus organizaciones representativas. Mientras el Partido Socialista volcó sus esfuerzos en convertir a los trabajadores extranjeros en ciudadanos con el objeto de cambiar el sistema a través de la participación electoral y la acción parlamentaria, los anarquistas pretendían destruir violentamente dicho sistema y construir uno nuevo negando todo diálogo (aun cuando no siempre fue así) con las entidades gubernamentales. El grado de arraigo del anarquismo entre los trabajadores se debió a que aprovechó los espacios que dejaba vacío el Estado, pero también a su combatividad y a su notable predisposición a defenderlos en cualquier circunstancia.

Durante las últimas décadas del siglo XIX los trabajadores organizaron los primeros sindicatos, se produjeron las primeras huelgas y se perfilaron las organizaciones anarquistas y socialistas. El impulso brindado por estas dos 
tendencias hizo posible la constitución de la Federación Obrera Argentina (FOA) en 1901, que nucleó una cantidad relativamente importante de sindicatos específicamente urbanos con eje en los carreros y obreros del puerto. Se produjo también la primera huelga general en 1901, limitada a la ciudad de Rosario, como respuesta solidaria a la represión policial. Al finalizar la primera década del siglo $\mathrm{xx}$ los trabajadores se hallaban relativamente bien organizados, estaban representados por ideologías del campo socialista fuertemente cosmopolitas y recurrían habitualmente a las huelgas y a otras formas de movilización para reclamar sus derechos. El malestar en el mundo laboral fue creciendo al aproximarse el Centenario de la Revolución de Mayo en 1910 y una clara evidencia en ese sentido lo constituía el hecho de que el gobierno, ante el temor de que se produjeran huelgas generales y atentados, creyó necesario apelar a fuertes medidas represivas para realizar los festejos sin sobresaltos. Así, se recurrió a la aplicación del estado de sitio, la censura de la prensa obrera y de sus manifestaciones ideológicas, se apeló al destierro, encarcelamiento y expulsión del país de numerosos dirigentes y se sancionó la Ley de Defensa Social que complementaba a la Ley de Residencia.

Las demandas obreras no eran percibidas por las autoridades sólo como exteriorización de malestar social, sino también como un desafio de clase y un síntoma de disgregación de la nacionalidad. En realidad, algunos confundían la cuestión social con el accionar de las organizaciones anarquistas que ponían en tela de juicio el sistema sin comprender que la propia existencia y desarrollo del anarquismo se debía en buena medida a la irresolución de la cuestión social, como habían advertido con lucidez Ernesto Quesada y Juan Bialet Masse (Suriano 2001). Si bien este tema venía siendo incorporado en la agenda de problemas a resolver por el gobierno, persistía una visión según la cual la protesta obrera y sus representaciones políticas e ideológicas eran un reflejo de los problemas de la sociedad europea y no un problema de la sociedad argentina.

Esta interpretación de los problemas obreros retoma viejas preocupaciones, como los temores a la inmigración masiva expresados por Sarmiento o el miedo a las multitudes analizado por Ramos Mejía, y se enmarca en un contexto que comenzaba a cuestionar la concepción liberal y, como contrapartida, efectuar una lectura desde el emergente nacionalismo cultural. En ese marco se produjo la intervención activa de sectores de las élites locales apelando a la patria y rechazando la protesta de los trabajadores y sus manifestaciones ideológicas. El celo xenófobo excedió su rechazo al mundo del trabajo y se extendió sobre el extranjero y en particular sobre los miembros de la colec- 
tividad judía. Se inauguró también una tradición de represión paraestatal a quienes eran considerados enemigos que se profundizaría con el tiempo.

Por la misma época se extendió también un espíritu de reforma política. En principio porque se debatió y sancionó la ley electoral en 1912 con la que se buscaba garantizar la limpieza del sufragio y que, al establecer su obligatoriedad, permitiera ampliar efectivamente la ciudadanía política de los varones mayores. Se consideraba que si los trabajadores se convertían en ciudadanos políticos esto implicaría un efecto positivo sobre la resolución de los problemas planteados en la cuestión social.

El espíritu de reforma social se enmarcó en esta etapa dentro de los límites del pensamiento liberal predominante y hasta la irrupción del nuevo siglo había dejado el problema en manos del asistencialismo y la filantropía, reservando su intervención a la esfera de la salud pública y la educación. Los liberales sustentaban una postura contractualista que se complementaba con el principio de responsabilidad según el cual cada individuo es el responsable de su existencia y tiene la obligación de hacerse cargo de sí mismo. Desde esta perspectiva, cualquier injerencia tendiente a asegurar socialmente a las personas era interpretada como atentatoria de la responsabilidad individual. En nuestro país el liberalismo practicado por los grupos dirigentes presentaba sus propias peculiaridades, pero sus lineamientos básicos se hallaban arraigados en buena parte de los gobernantes y en diversos sectores de la sociedad con intereses diferentes, desde las organizaciones empresariales hasta las gremiales orientadas por el anarquismo que pretendían colocar al Estado al margen de la cuestión.

Pero ahora, impulsado por el conflicto obrero en primer lugar, por las políticas sociales desplegadas en otros países, el desarrollo de las ciencias sociales, la preocupación de ciertos profesionales (médicos, abogados), el surgimiento del catolicismo social y la acción socialista, los gobernantes comenzaron a pensar las formas de resolución de la cuestión social combinando medidas represivas con la sanción de leyes protectoras de los trabajadores. Donde mejor se expresa este espíritu es en el proyecto de ley nacional del trabajo impulsado en 1904 por el ministro del Interior Joaquín V. González. Sus objetivos apuntaban a dar respuestas y aplacar el conflicto social y también a integrar a los trabajadores al sistema mediante una estrategia que combinaba la coerción y el consenso. Así, el Estado argentino comenzó a involucrarse en el conflicto social y a mediar en las relaciones entre los trabajadores y los empresarios.

El proyecto de González fracasó por varios motivos. En principio por el escaso interés del Parlamento y la falta de convicción del propio gobierno, 
pero centralmente por la oposición de los propios actores involucrados. La Unión Industrial se oponía porque pensaba que perjudicaría el desarrollo industrial nacional a favor de los productos extranjeros y porque consideraba que la intención de los gremios era destruir el sistema capitalista. La Federación Obrera, orientada por los anarquistas, coincidía en la oposición pero, invirtiendo los argumentos utilizados por los industriales, sostenía que el gobierno buscaba favorecer a los patrones y atentaba contra la libertad de asociación al establecer el proyecto una fuerte regulación de la actividad sindical y la prohibición explícita de la acción anarquista.

Ni la magnitud del conflicto social, ni el esfuerzo de un puñado de reformadores compuesto por socialistas, profesionales y funcionarios era suficiente para legislar socialmente. La falta de convicción de los grupos gobernantes y de consenso de los propios actores involucrados fue el principal motivo del fracaso del proyecto. No obstante, marcó el comienzo del accidentado y complejo proceso de la construcción del Estado social. De hecho, de la iniciativa del ministro González y de la perseverancia del diputado socialista Alfredo Palacios aparecieron las primeras leyes laborales como las que limitaban la jornada laboral y la que regulaba el trabajo femenino e infantil. También fue un subproducto de dicho proyecto la creación, en 1907, del Departamento Nacional del Trabajo (DNT). Aunque esta institución estuvo condicionada por los bajos presupuestos y la falta de poder de policía, cumplió un rol fundamental en el estudio y la elaboración de diagnósticos sobre los diversos problemas, como salarios, condiciones de trabajo, costo de vida o el estado de la legislación en otros países, y contribuyó a conformar un cuerpo de técnicos especializados en el tema.

Por otra parte, el mundo del trabajo también estaba conformado por mujeres. Ellas se incorporaron de diferente modo a las actividades productivas asalariadas, pero a diferencia de los varones, su ingreso fue visto con un efecto perturbador, disgregador y degenerador de la vida familiar y social. Para evitar esos efectos se diseñaron políticas sociales que se basaban en ciertos criterios y presupuestos sobre la división del trabajo, el poder y la responsabilidad diferenciada de hombres y mujeres. En 1907 se aprobó una ley que con modificaciones establecía disposiciones que amparaban a los menores, la jornada laboral de 8 horas para menores de 16 años, la prohibición de trabajar en industrias insalubres y peligrosas y del trabajo nocturno, la colocación de asientos para las empleadas, el permiso para amamantar a los hijos sin computarse en el tiempo de descanso, así como el reconocimiento de una licencia maternal de treinta días por nacimiento. 
También se registran en la época las primeras intervenciones en materia de seguridad social. Aunque las propuestas iniciales se remontan a 1902, recién en 1915 se sancionaron las leyes de accidentes de trabajo y de jubilaciones ferroviarias. Ambas fueron iniciativas estatales en respuesta a las huelgas de los trabajadores y eran superadoras de las que reglamentaban las condiciones de trabajo enmarcadas por el derecho civil, puesto que, en cierta forma, inauguraban el campo del derecho obrero (Isuani 1985: 83-90).

La llegada de los primeros gobiernos elegidos mediante la nueva ley electoral no cambió sustancialmente el diseño de las políticas sociales, aunque sí se modificaron las modalidades de intervención del gobierno ante el conflicto social. Para la nueva gestión radical, especialmente para el presidente Hipólito Yrigoyen, los trabajadores y sus representaciones gremiales se constituyeron en un sujeto con el cual se debía dialogar, pues era parte de un conglomerado social más amplio (el pueblo). Desde la perspectiva "krausista" sustentada por el mandatario, el pueblo constituía la "fuerza moral" de la nación en oposición al régimen ("la oligarquía") y el partido era concebido como un movimiento que excluía a los enemigos de la nación (Roig 1969). El conjunto de los trabajadores era parte de este movimiento y el radicalismo, si bien tenía un interés electoral, al intentar captarlos buscaba ampliar las bases sociales del Estado en correspondencia con su idea de nación (Falcón 1996). Por ello debía incrementar sus funciones asistenciales incorporando a los sectores hasta entonces marginados.

Ahora bien, la política de integración social de los trabajadores fue, cuando menos, ambigua. El gobierno firmó tratados con España e Italia sobre reciprocidad en materia de indemnización por accidentes de trabajo y se avanzó apenas en el terreno legislativo pues sólo se sancionó la ley que reglamentaba el trabajo a domicilio. El proyecto más ambicioso fue el Código de Trabajo, elaborado en 1921, que era un remedo del proyecto González de 1904, aunque pusiera menor énfasis en los aspectos represivos e intentara otorgar mayores facultades de intervención al Departamento Nacional del Trabajo. El Código se elaboró bajo los efectos de los acontecimientos de la Semana Trágica de 1919 y del movimiento huelguístico general.

El principal cambio con respecto a la política social de estos años se relaciona con la intervención personal y directa del presidente Yrigoyen en los conflictos obreros, pero se trataba de una mediación corporativa sin respaldo de ninguna instancia institucional (Garguin 2000). Aunque en ocasiones delegaba esa responsabilidad en terceros, en numerosas oportunidades se involucró personalmente, en especial cuando las huelgas afectaban el tránsito marítimo 
y terrestre. La intervención de Irigoyen a favor de algunos trabajadores en huelga provocó la ira de los sectores más conservadores de la sociedad, quienes despreciaban la popularidad y el aire plebeyo del primer mandatario. Además, consideraban cualquier concesión de tipo social o política realizada por el gobierno como una violación de los principios de libertad de empresa.

Esta mirada crispada era producto de un complejo contexto en el cual se entrelazaban acontecimientos locales como el propio triunfo radical que ratificaba la desconfianza de las élites por la democracia, el marcado cosmopolitismo de la sociedad urbana, el importante ciclo huelguístico de 1917 a 1921 y la Semana Trágica, con la situación internacional en la que se destacaban la Revolución Soviética y la crisis de la democracia liberal. La naturaleza de cada una de estas cuestiones era diferente, aunque en conjunto conformaran un panorama político y social incierto.

Pero si observamos los acontecimientos locales la coyuntura parecía lejana a cualquier situación revolucionaria. Por ejemplo, en el movimiento huelguístico iniciado en 1917 predominaban abrumadoramente las reivindicaciones económicas, especialmente la recomposición salarial deteriorada durante la guerra. Incluso en los hechos sangrientos de la Semana Trágica de enero de 1919 la gravedad alcanzada por el conflicto puede asociarse más a la brutal intervención policial que a la radicalidad de los manifestantes. En todo caso, el hecho notable del movimiento laboral de este período fue la constatación de la existencia de una cultura obrera a la que había que tomar en cuenta. Debe señalarse, además, que las corrientes más importantes del movimiento obrero, el sindicalismo y el socialismo, si bien defendían los intereses obreros, no atentaban contra el sistema, por el contrario habían impulsado y aceptado el rol arbitral del gobierno en las relaciones obrero-patronales. Por su parte, el anarquismo, que había sido el principal actor de las luchas obreras de la década anterior, se hallaba en decadencia y sumido en polémicas internas que lo debilitaba; mientras el comunismo no tenía influencia todavía en los gremios más poderosos.

Sin embargo, algunos sectores de las élites parecían temer una posible revolución social y tanto los trabajadores como sus representaciones gremiales, ideológicas y políticas eran visualizados no sólo como enemigos de clase, sino también de la patria. Claro que es difícil saber hasta qué punto ese temor era sincero y hasta dónde era el resultado de los discursos encendidos de los contendientes del conflicto social. Algunos, como el diario La Nación, lo utilizaban como pantalla para atacar al gobierno y acusarlo de inacción frente al conflicto y de complicidad con los huelguistas. Otros, como la recién creada 
Asociación Nacional del Trabajo (ANT), que reunía a los empresarios más poderosos, suponían que eran afectados por las demandas y ofrecían custodia armada y rompehuelgas a las empresas cuyo personal se hallaba en conflicto. En realidad, la ANT era una verdadera organización de clase que no estaba dispuesta a negociar y conceder mejoras a los trabajadores y ni siquiera escuchar los llamados de la Iglesia

Esta última, sacudida por las "tormentas sociales" de 1919, también planteaba la defensa del orden social y pretendía neutralizar la influencia de las agrupaciones de izquierda, pero, más que dedicarse a hostigar al gobierno, profundizaba la idea de reforma social que veinte años atrás habían introducido con los Círculos de Obreros Católicos. Ahora, mientras monseñor Miguel de Andrea pensaba una alianza de diversos sectores de la élite conducida por la Iglesia y se abocaba a organizar la Gran Colecta Nacional destinada a los sectores más necesitados, Gustavo Franceschi avanzaba un paso más y desde una perspectiva antiindividualista retomaba los principios de la bula Rerum Novarum para plantear la necesidad de que la justicia social debía ser orientada desde el propio Estado.

Ciertamente, las críticas de la oposición que sostenían el carácter obrerista del gobierno radical parecen, cuando menos, exageradas, porque si bien es cierto que su intervención era más comprensiva y neutral que durante los gobiernos conservadores, también lo es que manifestó tendencias ambiguas y en numerosas ocasiones apeló a la represión para resolver los conflictos. En este sentido, basta observar las diferencias en el comportamiento gubernamental frente a las huelgas de diversos gremios como los navales, ferroviarios, obreros de la carne o los municipales. Esa ambigüedad salta a la vista con mayor claridad durante la Semana Trágica y en las huelgas de los peones de la Patagonia en 1921. En ambos conflictos, el gobierno apeló en un comienzo a la negociación y terminó propiciando, bajo fuerte presión de las élites, una feroz represión. Incluso, apeló al ejército y no desalentó la formación de grupos civiles de represión; es más, muchos militantes radicales participaron del ataque a locales obreros y extranjeros y más tarde formarían en las filas de la Liga Patriótica.

El período turbulento finalizó cuando se regularizó la economía y el gobierno de Marcelo T. de Alvear pudo transitar los caminos de la paz social. La política social volvió a subordinarse a las iniciativas legislativas, pues el nuevo presidente confiaba más en el Parlamento y se hallaba alejado de las prácticas políticas de intervención directa a las que era proclive Irigoyen. Pero el principal logro de su gestión, la ley de jubilaciones $n^{\circ} 11.289$, sancionada en 
1923, debió anularse dos años más tarde por la oposición combinada de las empresarios reunidos en la ANT y del movimiento obrero en un hecho que rememora el rechazo del Ley Nacional de Trabajo dos décadas antes.

Durante la etapa radical, la política social se mantuvo dentro de los moldes inaugurados a comienzos del siglo y recién se modificaría en un sentido más profundo durante las décadas siguientes, más allá de la tendencia de Yrigoyen por alcanzar un diálogo más fluido con los trabajadores,

\section{CONTORNOS IDENTIFICABLES DE LOS DERECHOS SOCIALES}

La crisis general de la economía desatada en 1929 marcaría un punto de inflexión en las responsabilidades asumidas por los Estados occidentales frente a los diversos problemas sociales. La gravedad alcanzada por la depresión obligó a los gobiernos de los países más industrializados a intervenir activamente en la economía, no sólo para reactivarla, sino también para hallar soluciones a las altas tasas de desocupación. Este proceso de involucramiento de los Estados en las esferas económica y social había comenzado ya a fines del siglo XIx bajo la influencia del constitucionalismo social, corriente de pensamiento que intentaba dar una respuesta a las diversas crisis del capitalismo, pero también al temor de las clases dirigentes al conflicto social y al desarrollo de los movimientos socialistas. Apenas finalizada la Primera Guerra Mundial, esta doctrina, que excedía el reclamo de derechos civiles y políticos, se extendió rápidamente planteando ampliar el régimen de garantías para los trabajadores y paliar los efectos sociales más nocivos del capitalismo a partir de una mejor distribución de la riqueza. Para ello, el Estado debía intervenir activamente en la economía regulando el funcionamiento del mercado e involucrando tanto al poder económico como político para intentar una mejor distribución de los ingresos y avanzar hacia la justicia social

Las experiencias de activa participación y planificación de la economía llevadas adelante por los gobiernos más comprometidos durante la Segunda Guerra Mundial confluirían de manera decisiva en el avance de los sistemas de protección social y en la formación de los Estados de bienestar, así como en la generalización de la ciudadanía social desde que, en 1945, buena parte de los países occidentales pusieran en marcha planes de seguridad social de carácter universalista inspirados en el hoy mítico informe Full employement in a free society, escrito en 1944 por William Beveridge en Gran Bretaña. El modelo adquirió rasgos particulares en cada país y es raro encontrar experiencias 
en las cuales el sistema solidario haya incluido a todos los individuos por igual. Sólo excepcionalmente funcionó de manera plena. Mientras en los países industrializados predominaron modelos más solidarios, en América Latina adquirieron un sesgo corporativo (Baldwin 1992).

Todos estos cambios repercutieron, a partir de la crisis de 1929, en diversos países de América Latina y de manera particular en Argentina, en donde influyeron de manera desigual en los gobiernos conservadores de los años treinta, quienes, sin abandonar sus convicciones liberales, debieron intervenir activamente en la economía a través de la creación de instituciones como el Banco Central y numerosas juntas reguladoras para paliar los duros efectos de la depresión. Por otra parte, debieron involucrarse en la resolución de los problemas sociales. Como consecuencia directa de la crisis se creó la Junta Nacional contra la Desocupación (1934), pero también se avanzó en materia de legislación laboral. Se sancionaron diversas leyes ratificando convenciones internacionales de la OIT, otras que reglamentaban el sábado inglés y varias de seguridad social. Además, se incentivaron las primeras convenciones colectivas de trabajo con la participación de las organizaciones gremiales, las cuales, sin dejar de apelar a las huelgas y sin perder su independencia, se mostraban proclives a la negociación y a la intervención del Estado.

En efecto, tanto aquellas organizaciones gremiales más radicalizadas impulsadas por los comunistas que dirigieron conflictos como la huelga general de los obreros de la construcción en 1936, como aquellas lideradas por socialistas o sindicalistas, quienes controlaban sindicatos claves como la Unión Ferroviaria, aceptaban la mediación estatal en los conflictos. Después de las turbulencias sociales de fines de la década de 1910 ganaba terreno rápidamente entre la mayoría de las organizaciones obreras la idea de que el cambio social se llevaría adelante en los marcos del sistema y ni la crisis de 1929 ni el golpe militar que derrocó a Yrigoyen modificó esta tendencia. Por otra parte, no sólo los sindicatos demandaban y generaban políticas sociales, en los ámbitos urbanos (especialmente en la ciudad de Buenos Aires) diversas organizaciones de la sociedad civil, como las sociedades de fomento, y partidos políticos de carácter vecinal generaron novedosas formas de demanda social a partir de la ocupación del espacio público (Gutiérrez y Romero 1995).

Aunque en estos años previos a la Segunda Guerra no debe exagerarse el rol de la intervención estatal, puede destacarse que alcanzó cierta envergadura y que la originalidad de esta acción no trataba tanto de institucionalizar el conflicto social como de organizar el funcionamiento del mercado de trabajo (Gaudio y Pilone 1984). Las estrategias de intervención fueron encaradas no 
sólo por el gobierno nacional, sino también por diversas administraciones provinciales. El gobierno de Perón amplió, profundizó y generalizó algunas de esas medidas.

Sin embargo, debe destacarse que Perón encontró un país que en los últimos años había cambiado en varios sentidos. Se había profundizado la relación entre las diversas regiones a partir de la expansión de los medios de comunicación, especialmente la radio, que se sumaban a la escuela y al servicio militar en la homogeneización cultural de la población y también debido a la extensión de la red de carreteras, que se sumaban al ferrocarril. Además, se produjeron cambios en la estructura social visibles en el crecimiento de los sectores medios y la nacionalización de la clase trabajadora debido a que la principal fuente de aprovisionamiento de mano de obra no era ya Europa, sino las provincias del interior. En este contexto se fue fortaleciendo el ascenso social y la gran novedad que trajo consigo la llegada del peronismo al poder "consistió en que el Estado se ocupó de allanarles el camino, removiendo los obstáculos y ampliando procesos que venían ocurriendo en la economía nacional" (Torre y Pastoriza 2002:278). El componente salarial en la renta nacional se elevó entre 1943 y 1948 del 44 al 53\% gracias a una política que privilegiaba el aumento de los salarios reales para expandir la demanda interna. Así, hubo aumentos generalizados para los empleados públicos y un respaldo del gobierno a las posturas sindicales en la fijación de salarios a través de los convenios colectivos. Como sostiene bien Carlos Altamirano, "la ideología peronista alcanzó su configuración clásica asociada a la prosperidad y pujanza de esos años" (2001:33).

Claro que hubo una serie de problemas económicos que alteraron este proceso de "democratización del bienestar". Por un lado, profundizando la tendencia preexistente los principales beneficios recayeron en las áreas urbanas en desmedro de las rurales no sólo porque los salarios ganados por los nuevos obreros industriales eran sustancialmente más altos que los de los obreros rurales, sino porque continuó el despoblamiento y el empobrecimiento de algunas provincias como las del noroeste. Por otra parte, las alzas de salarios se detuvieron en 1949 cuando se invirtieron los términos de intercambio al bajar los precios del agro y subir los de los bienes importados. Las dificultades económicas frenaron el alza de salarios y la redistribución de los ingresos. También se puso en evidencia el problema de la baja productividad en la industria que el gobierno intentó resolver apelando a la colaboración de la dirigencia sindical. Sin embargo, se hallaron con la férrea resistencia de los delegados de base que generó conflictos importantes entre los trabajadores y el gobierno peronista. 
No obstante los límites impuestos por la economía, podría sostenerse que en comparación con los períodos previos la sociedad móvil argentina de los años del peronismo fue "una sociedad con una estructura más igualitaria". Los sectores populares pudieron consumir más que nunca antes en alimentos, vestimenta, vivienda y artículos electrodomésticos y los trabajadores mejoraron su situación (Torre y Pastoriza 2002: 282-283). En este sentido, los resultados de la política social en su sentido más amplio, más allá de las luces y sombras que presentan, fueron ciertamente importantes.

En el área educativa el proceso democratizador iniciado medio siglo antes se profundizó y la escuela primaria se extendió a los sectores de menores recursos, contribuyendo a bajar el ya bajo índice de analfabetismo. El mayor avance se produjo en el crecimiento de la enseñanza secundaria, que duplicó el número de alumnos, provenientes en buena medida de familias trabajadoras.

El gobierno también intervino activamente en las áreas de turismo y vivienda. En el primer caso se invirtieron fondos para promocionar el turismo y se incentivó la construcción de hoteles y colonias de vacaciones. Los beneficios de este proceso no alcanzaron a todos por igual y "se distribuyeron siguiendo las líneas de estratificación interna de las clases asalariadas" (ferroviarios, estatales, municipales, empleados de correo y comercio). El derecho a la vivienda también estaba contemplado en el programa de gobierno y benefició tanto a los empleados públicos a través de créditos baratos otorgados por el Banco Hipotecario, como, en menor medida, a los sectores de menores recursos a través de la construcción de viviendas que a la vez estimulaban la construcción. Muchos de quienes no pudieron alcanzar la vivienda terminaron habitando en las cada vez más numerosas villas de emergencia que se convirtieron en un dato insoslayable de la geografia urbana argentina de la segunda mitad del siglo xx.

En el área de salud los avances se expresaron en la duplicación de la atención médica, la oferta de una mayor infraestructura hospitalaria y el mejoramiento de servicios (cloacas, agua) que beneficiaron centralmente a los sectores medios y a los trabajadores urbanos. Sin embargo, el gobierno peronista fue incapaz de imponer un sistema de salud de carácter universalista, puesto que colisionaron los intereses del Ministerio de Salud Pública, la Fundación Eva Perón, que reemplazó a la vieja Sociedad de Beneficencia y se reservó para sí la atención asistencial de los sectores más pobres, y los sindicatos, que privilegiaban la provisión de servicios médicos a través de las obras sociales basadas en criterios ocupacionales. De esta forma se generó un sistema de salud con algunas características negativas que se han mantenido hasta el pre- 
sente (Belmartino 2005). En cierta forma esta fragmentación de la solidaridad pública también se expresó en el sistema de jubilaciones. Si bien es cierto que de medio millón de trabajadores en condición de jubilarse en 1943 se pasó a un millón y medio en 1955, también lo es que esos beneficios dependían de la disímil capacidad de presión de los gremios en el mercado laboral. De esta forma, aquellos sindicatos más poderosos lograban mejores condiciones de jubilación para sus afiliados contradiciendo los principios solidarios universales de la seguridad social moderna.

"La democratización del bienestar" y, más específicamente, la política social destinada al mundo del trabajo se respaldaron en una sólida legislación social cuya base se estableció tempranamente durante el gobierno militar surgido del golpe militar de 1943, cuando el entonces coronel Perón estuvo al frente de la Secretaría de Trabajo y Previsión. Fue entre 1943 y 1946 cuando Perón amasó su capital político que se sancionó en alrededor de setenta decretos (ratificados por la ley $n^{\circ} 12.921 / 46$ ), que si en muchos casos retomaban y profundizaban aspectos de la legislación obrera ya existente, en otros significaban un avance sustancial en materia de legislación laboral. Además, se crearon numerosos tribunales de trabajo, se sancionó el escalafón y el régimen de estabilidad de los empleados públicos, estatutos para trabajadores de diferentes profesiones, se creó el Instituto Nacional de Previsión Social que apuntaba a generalizar los regímenes de jubilaciones y se reglamentó la organización y aprendizaje del trabajo de los menores.

Si estas medidas generaban la masiva adhesión de los trabajadores y la creciente desconfianza del mundo empresarial, aun cuando Perón pretendía una relación armónica entre las clases, esta brecha se ensancharía de manera notable a partir de las dos medidas más espectaculares decretadas durante su gestión en el gobierno de facto. La primera fue la sanción del Estatuto del Peón, que creó un régimen de amparo de los trabajadores rurales, prácticamente desprotegidos hasta entonces, que establecía salarios y estabilidad así como normas de higiene, alojamiento, descanso y alimentación. Ésta fue una medida disruptiva, ya que intervenía en ámbitos laborales poco acostumbrados a la ingerencia del Estado. La segunda medida que causó un profundo impacto fue un decreto de enero de 1945 que establecía las vacaciones pagadas para todos los trabajadores del país, incluidos los peones rurales.

La política social implementada por Perón fue posible gracias a cuestiones antes señaladas como las mejoras estructurales de la economía o la influencia del clima de ideas de la coyuntura (constitucionalismo social, informe Beveridge). Pero también constituyeron fuentes de inspiración la Doctrina 
Social de la Iglesia, ciertas orientaciones de las políticas sociales corporativas del fascismo italiano, así como la dudosa necesidad de alejar los peligros del comunismo y la lucha de clases.Y está, claro, el factor político que en ocasiones lo llevaban a impulsar medidas sospechadas de oportunismo electoralista como cuando en vísperas de las elecciones de 1946 Perón otorgó un aguinaldo generalizado.

En 1947 se proclamaron formalmente los derechos de los trabajadores basados en el corpus legal sancionado hasta entonces y que significativamente no contemplaba el derecho de huelga. Estos derechos serían incorporados a la nueva Constitución nacional sancionada en 1949 en donde, además, se declamaba la intervención del Estado en la economía, la propiedad estatal de las fuentes de energía y los servicios públicos y la función social de la propiedad. Más allá de aciertos y defectos, el proceso de construcción de los derechos sociales alcanzaba al promediar el siglo xx su momento culminante al ser incorporados en la Constitución y estar plasmados en un corpus legislativo.

Aunque los gobiernos cívico militares que se sucedieron después del golpe de 1955 intentaron modificar la política social plasmada durante los primeros gobiernos peronistas, ésta no sufrió grandes cambios estructurales hasta promediar los años setenta y se mantuvieron los principales pilares del Estado social. Incluso aunque la Convención Constituyente reunida en 1957 derogó la Constitución de 1949, introdujo los derechos sociales en la vieja Constitución a través del artículo $n^{\circ} 14$ bis, asegurando, entre otros derechos, las condiciones de trabajo, la jornada laboral limitada, el descanso y las vacaciones pagadas, el salario mínimo, vital y móvil, la protección contra el despido arbitrario, las jubilaciones, el acceso a la vivienda digna o el derecho de huelga.

No obstante, las relaciones entre los trabajadores y el Estado se complejizaron por diversos motivos. En principio, tanto la represión como la prohibición política del peronismo afectaron a los trabajadores. Se expulsaron numerosos activistas y delegados fabriles, las condiciones laborales empeoraron, se deterioró el salario y los ritmos de producción se intensificaron. La situación generó la radicalización de un sector del peronismo, que terminó en una división del movimiento peronista que condicionaría la política argentina durante dos décadas. Por otro lado, en los años sesenta, la radicalización política e ideológica de sectores del sindicalismo, ya sea los "combativos" (peronistas) o la corriente clasista (izquierda revolucionaria), la irrupción y desarrollo de la guerrilla, la regionalización de los conflictos sociales y la ampliación de sus actores (estudiantes, sacerdotes, vecinos) generaron un mapa de movilizaciones populares que se extendió por todo el país (Neuquén, Córdoba, 
Tucumán, Chaco, Misiones, Villa Constitución) y excedieron largamente al tradicional centro político (Buenos Aires). Las reivindicaciones de estos movimientos eran variadas y podían orientarse a las tradicionales luchas salariales, o a las mejoras en las condiciones de trabajo o a la preservación de la fuente de trabajo como ocurriera durante el cierre de numerosos ingenios azucareros en Tucumán; pero también podía reclamar la legalización del movimiento peronista y el levantamiento de la proscripción de su líder; finalmente, algunos sectores excedieron los reclamos de corte económico e impulsaron el conflicto en un sentido solidario, buscaron democratizar la vida sindical y, en ocasiones, intentaron seguir un camino revolucionario como ocurriera con los sindicatos clasistas cordobeses.

En este contexto, y como se sostiene más arriba, el Estado social no sufrió grandes modificaciones, aunque es cierto que en algunas coyunturas se intentó disminuir la presencia del sector público y en otras, los trabajadores fueron afectados por políticas, represivas o eficientistas, que podían derivar en depreciación salarial, empeoramiento de las condiciones laborales, intensificación de los ritmos de trabajo y en despidos. Pero el núcleo del Estado social se mantuvo incólume e incluso profundizó algunas características como su fragmentación.

El CERCENAMIENTO DE LA CIUDADANía SOCIAL

Más allá de algunas limitaciones del Estado social en nuestro país, es indudable que, mientras persistió, logró articular e integrar socialmente a la gran mayoría de los trabajadores. Con la irrupción de la dictadura militar en 1976 esta integración social comenzó a desarticularse al plantearse, entre otros objetivos, el desmantelamiento de las políticas de intervención estatal. Para ello, los militares se ampararon en una inusual política represiva basada en el terrorismo de Estado y la desaparición forzada de personas que golpeó duramente a las organizaciones políticas y sindicales, acallando en buena medida las voces discordantes.

En un contexto internacional en el cual los países más industrializados comenzaban a percibir la crisis fiscal de los Estados de bienestar y a inclinarse por la supremacía del mercado, la política encabezada por el ministro Martínez de Hoz llevó adelante una apertura económica basada en la creación de un mercado de capitales a corto plazo, un dólar barato, la liberalización de las tasas de interés y la movilidad sin trabas de las divisas. Una de las consecuen- 
cias graves de esta estrategia derivó en la reducción de la actividad industrial, una caída salarial y el aumento de la desocupación que, no obstante, no superó el $8 \%$ gracias al crecimiento de la actividad cuentapropista.

Si la apertura económica era una condición básica del plan económico, el achicamiento del Estado era el otro pilar sobre el que se sustentaba. El comienzo del proceso de desestatización afectó de manera diferente a diversos servicios públicos y preparó el camino para el proceso privatizador de los años noventa. La disminución de la presencia estatal en la economía implicaba también el inicio de la desarticulación del Estado social. Se produjo una disminución del gasto social que afectó diversas áreas del aparato estatal. Por ejemplo, la educación pública que era concebida por los militares como ámbito de disciplinamiento y legitimación de la dictadura, sufrió un fuerte embate descentralizador porque se transfirió a la municipalidad de la ciudad de Buenos Aires y a las provincias la responsabilidad financiera de la totalidad de las escuelas primarias y preprimarias con el objeto de achicar los gastos del presupuesto nacional. Muchas provincias, especialmente las más pobres, manifestaron serias dificultades para financiar la actividad educativa y esto se reflejó en una notable disminución del gasto destinado a educación, así como también en la calidad de la enseñanza. La disminución de la financiación (y de la responsabilidad) estatal condujo a traspasar la necesidad de generar recursos adicionales a las familias de los alumnos (Belmartino 2005).

Durante el gobierno militar se abandonaron las políticas de vivienda que protegían a los sectores más necesitados al derogarse el régimen de locaciones urbanas vigentes desde el primer peronismo y erradicarse de manera compulsiva las villas de emergencia sin brindar una solución alternativa a los afectados. También se produjo un notorio deterioro del sistema previsional debido a la creciente extensión del trabajo "en negro", la evasión de los potenciales contribuyentes, la caída salarial y la menor contribución empresaria al financiamiento del sistema. Por otra parte, comenzó a transferir la administración del área de salud al sector privado.

La aplicación de esta política se amparó en una amplia legislación represiva que apuntaba a garantizar la seguridad de las empresas industriales y comerciales prohibiendo las actividades gremiales, suspendiendo el derecho de huelga, eliminando los fueros sindicales especiales, reimplantando la ley de residencia y quitándole peso a los convenios colectivos y contratos de trabajo. La represión cayó de manera implacable sobre los delegados y activistas más combativos, buena parte de los cuales desaparecieron o fueron encarcelados, pero también intentó neutralizar el poder del sindicalismo tradicional. En 
este sentido, el punto culminante fue el intento de eliminar a la CGT y a los grandes gremios por rama para abrir un proceso de conformación de sindicatos pequeños influenciados por el régimen. Además, por un tiempo, le sustrajo a los sindicatos el control de las obras sociales, privándoles de uno de sus principales recursos económicos. Pero esta medida tenía, además, una grave implicancia, pues afectaba el funcionamiento de las obras sociales y se desarticulaba buena parte del sistema de atención social de los trabajadores.

Como es sabido, la dictadura militar debió abandonar el gobierno mucho antes de lo que pensaba, dejando trunco su proyecto. Sin embargo, las bases de la desestructuración de los derechos sociales por los cuales los trabajadores habían bregado durante tanto tiempo estaban instaladas, no tanto por las reformas realizadas por los militares como por cierto consenso que se estaba generando en la sociedad sobre la ineficacia administrativa del Estado. Si bien esta percepción social en parte era justificada por las propias limitaciones demostradas por la administración estatal, fue alimentada por un discurso unilineal, maniqueo y carente de matices a favor de la libertad de mercado emitido por economistas neoliberales y supuestos comunicadores sociales cuyo axioma básico, "achicar el Estado es agrandar las nación”, terminó de consensuarse socialmente durante la dificil transición democrática.

El gobierno de Raúl Alfonsín, que debió insumir casi todas sus energías en enfrentar el problema militar y la cuestión de los derechos humanos, demostró una confianza un tanto ingenua en el poder de la democracia pare resolver problemas estructurales. Tal vez por ello no alcanzó a acertar el rumbo de la política económica en un contexto internacional en donde las transformaciones neoliberales se imponían con rapidez. Las políticas sociales del gobierno radical buscaban preservar el ahora tambaleante y denostado Estado social. Sin embargo, la ambigüedad de su política económica fue duramente atacada desde los ámbitos neoliberales pero también desde una hipócrita postura de la oposición peronista quien, con un discurso nacionalista que mutaría radicalmente después, se opuso terminantemente a la tibia reforma del Estado planteada por el gobierno. Esa oposición se manifestó tanto en el Parlamento como en el inusitado número de huelgas generales declaradas por la CGT que pusieron en jaque a un gobierno incapaz de hallar respuestas a los diversos aspectos de la crisis.

Sumados al desgaste provocado por la presión militar, el proceso hiperinflacionario, las demandas sociales, la acelerada pérdida de poder político y el enorme déficit del Estado fueron minando progresivamente el consenso social del gobierno radical y aceleraron la caída del presidente Alfonsín, de- 
jando abiertas las puertas para las profundas reformas de la economía y de las políticas estatales. La paradoja de este proceso residía en que sería un dirigente peronista quien llevaría adelante una transformación destinada a barrer con las bases del Estado social que, después de medio siglo de demandas sociales, se había plasmado durante los primeros gobiernos peronistas y había perdurado más de tres décadas.

Fue el presidente Carlos Menem quien asumió la defensa a ultranza de las bondades del mercado. Sus nuevas convicciones lo llevaron a efectuar una alianza implícita con los sectores políticos neoliberales y los factores del poder económico y financiero produciéndose un proceso de subordinación de la política a la economía (Svampa 2005). Así, se liberaron los precios, se abrió casi sin restricciones la importación, se eliminó el régimen de promoción industrial, se estableció la paridad cambiaria con el dólar (convertibilidad) y el Estado resignó su capacidad de intervención en el mercado.

Apresuradamente y frenando cualquier posibilidad de establecer un debate político y social, se realizó una drástica y desprolija política de reforma del Estado. Bajo la influencia de las organizaciones internacionales de crédito y del Consenso de Washington, que planteaban la apertura de los mercados y la retirada del Estado de la economía, a partir de 1989 se privatizaron las principales empresas públicas (Aerolíneas Argentinas, YPF, ENTEL, Ferrocarriles, Gas del Estado, entre las más importantes). Este proceso se extendió a las áreas sociales controladas por el Estado y que, en cierta forma, representaban la base del Estado social. La crisis que atravesaban los sistemas previsional y de salud sirvió de argumento para desarticularlos y privatizarlos, así como fueron desmantelas las políticas de vivienda. Por otra parte, se profundizó la descentralización educativa iniciada por la dictadura al transferirse ahora a las provincias los establecimientos educativos de nivel medio y superior no universitario dependientes del Ministerio de Educación y las escuelas dependientes del Consejo Nacional de Educación Técnica.También se delegó en las provincias la supervisión y financiamiento de los establecimientos del sector privado radicados en ellas.

Por otro lado, para llevar adelante el profundo proceso de reconversión industrial y flexibilización laboral fue necesario desarticular el tradicional mundo del trabajo industrial eliminando las protecciones que el Estado social brindaba a los trabajadores. Para concretar este proyecto, el gobierno de $\mathrm{Me}$ nem debió establecer una nueva normativa legal que le permitiera destruir las regulaciones colectivas vigentes para reemplazarlas por las reglas del mercado que individualizarían indefectiblemente las relaciones laborales. Esto fue po- 
sible no sólo gracias al consenso de una parte importante de la sociedad, sino también al disciplinamiento del heterogéneo conglomerado del movimiento peronista. En esta última tarea fue importante la subordinación de la mayoría de los grandes sindicatos nucleados en la CGT que, a cambio de obtener algunos espacios de poder, apoyaron el modelo neoliberal y colaboraron con la reforma gubernamental frenando la protesta de los trabajadores perjudicados por el proceso privatizador, especialmente en los servicios públicos (ferroviarios, telefónicos, estatales, petroleros).

El resultado de este proceso de "modernidad excluyente" implicó un impresionante aumento del desempleo y el subempleo, cuya resultado más dramático significó la expulsión de un sector importante del viejo mundo del trabajo fuera del sistema de protección social. Se produjo, en términos de Castel, un proceso de "descolectivización" de los trabajadores, consistente en la pérdida de los soportes colectivos constituyentes de la identidad de los sujetos, que condujo a la individualización de las relaciones sociales (Castel 1997). Como consecuencia de estas transformaciones se ha planteado una nueva cuestión social en la que el problema central se plantea qué hacer con el amplio segmento de individuos excluidos del sistema (los nuevos pobres). Este nuevo sector social ha generado una nueva geografia social de la protesta al tener que apelar a nuevas formas de organización y movilización (piquetes), pues la huelga sólo es un repertorio de confrontación válido en condiciones de ocupación laboral regular. También se ha producido un cambio radical de las tradicionales demandas relacionadas con el mundo del trabajo por otras que implican el reclamo de recuperar el derecho al trabajo o recuperar la protección estatal.

La respuesta del Estado a la nueva cuestión social parece haber aceptado la premisa de que el bienestar ya no es un derecho, sino una cuestión de oportunidad personal (accede al bienestar aquel individuo en condiciones de hacerlo). En este sentido, los paliativos a la nueva pobreza han consistido en aplicar políticas asistenciales y focalizadas con un fuerte sesgo clientelístico que no modifican la situación de exclusión y tienden a reforzar el desarrollo de una "ciudadanía restringida" (Svampa 2005).

No obstante la gravedad de la crisis, en los últimos años la situación macroeconómica ha mejorado, se ha logrado la estabilidad monetaria y un equilibrio fiscal impensado pocos años atrás. Hay ciertos signos aparentemente positivos: los niveles de empleo han evolucionado favorablemente y la tasa de desocupación ha disminuido; un sector de los trabajadores ha recuperado su capacidad de presión aun cuando, en la mayoría de los casos, bajo la con- 
ducción de un sindicalismo anclado en el pasado que esgrime métodos de confrontación y organización escasamente democráticos; las nuevas formas de protesta social ha mermado sustancialmente tanto a partir de la generalización de las políticas asistenciales como de las tácticas de desgaste desplegadas hacia las organizaciones sociales por los gobiernos de Néstor Kirchner y de su esposa Cristina Fernández de Kirchner, que por otra parte, emite un discurso con un fuerte tono de preocupación social que recupera las viejas bondades del Estado benefactor. Sin embargo el interrogante sobre el futuro de la ciudadanía social o las formas que pueda asumir queda abierto. 
II. NUEVAS FORMAS DE CIUDADANÍA 


\title{
LOS CIUDADANOSY CIUDADANAS MENORES DEL PERÚ
}

\author{
Jeanine Anderson \\ Helen Palma Pinedo
}

\section{INTRODUCCIÓN}

La condición ciudadana de los niños, niñas y adolescentes es ambigua en el Perú. Los menores de edad gozan de la protección especial del Estado y adquieren ciertos derechos desde el momento que nacen e incluso antes. ${ }^{1} \mathrm{El}$ Estado reconoce la obligación de promover su desarrollo, así como velar por su integridad fisica y moral. Sin embargo, los peruanos que aún no alcanzaron la edad adulta legal -18 años- dependen de otras personas para poder ejercer la mayor parte de sus derechos. Esas otras personas - padres, tutores, padrinos, familiares más allá de la línea directa, padres socialmente reconocidos, entes caritativos, organismos del Estado en última instancia- pueden o no ser dignos, sinceros y eficaces representantes de los intereses de los menores. Las tensiones entre la protección y la indefensión, el tutelaje y la explotación no son exclusivas del Perú. Aquí, como en otros países, crean un cuadro lleno de

1 El aborto, salvo terapéutico, es ilegal y los derechos de los no nacidos son defendidos tenazmente en sectores de opinión aliados a la Iglesia católica y protestantes fundamentalistas. Muchos ciudadanos menores peruanos viven fuera del territorio nacional, debido a la fuerte corriente de migración internacional de las últimas dos décadas, que ha llevado al $10 \%$ de la población peruana a destinos en Europa, Norteamérica y otros países latinoamericanos. Los hijos de ciudadanos nacidos en el exterior pueden acceder a la ciudadanía al ser inscritos en los consulados. El Perú reconoce la condición de doble ciudadanía. 
contradicciones que expresan la ambivalencia de la generación adulta frente a cada nueva generación: inspira esperanza, confianza y abnegación, sin duda, pero también rivalidad y temor.

Este artículo echa una mirada a las complejidades de la ciudadanía de niños, niñas y adolescentes en el Perú. Comenzamos con una breve discusión sobre la teoría y la realidad de la ciudadanía de adultos y no adultos en el marco del orden generacional peruano. Luego, examinamos la situación legal y el reconocimiento del estatus particular de los menores de edad, así como su atención mediante las políticas públicas. Seguidamente, enfocamos dos situaciones particularmente conflictivas, el trabajo infantil y la maternidad y paternidad adolescentes. Luego, pasamos a ver la participación política como una faceta de la ciudadanía y nos preguntamos cómo esta participación se canaliza en el Perú tratándose de menores de edad. El tratamiento a los niños, niñas y adolescentes en tanto ciudadanos nos habla de las condiciones que el Perú ofrece para el respeto hacia la diversidad cultural, nuestro siguiente tema. Finalmente, enunciamos algunas conclusiones que vuelven sobre los problemas de ambigüedad y contradicción, nobles ambiciones y fracasos en la práctica, que forman parte de la espinosa realidad de cuánta ciudadanía pueden reclamar y gozar los niños, niñas y adolescentes en el Perú.

CiUdAdANía y EL ORDEN GENERACIONAL: LA TEORÍA Y LA REALIDAD

El concepto de ciudadanía es controvertido, en teoría y en la aplicación. Una colección reciente (Van Bueren 2011), que pasa revista al estatus de los menores de edad en el mundo, asume como denominador común los siguientes componentes de la ciudadanía:

1. Poseer derechos individuales y ser titular de dichos derechos.

2. Compartir relaciones recíprocas con otros ciudadanos en tanto miembros de una comunidad nacional.

3. Participar económica y políticamente.

4. Ser facultado para representarse y exigir el cumplimiento de los derechos ante tribunales nacionales e internacionales.

Todos estos elementos suelen ser reglamentados sobre el supuesto de que sean personas adultas quienes reclaman sus derechos, cumplan con sus deberes en forma activa, tengan consciencia de pertenecer a una comunidad nacional 
y suscriban un contrato social implícito que las vincula al resto de sus conciudadanos. Indudablemente, aun las personas legalmente adultas (mayores de edad) no siempre tienen la capacidad para defender sus intereses ante la ley; pensemos en los casos de aquellas con discapacidades mentales o físicas. Sin embargo, está clara la dificultad de trasladar estos criterios al mundo infantil: ¿se trata de ciudadanos-en-potencia? ¿Ciudadanos parciales? ¿Ciudadanos adjetivados de otras maneras?

El concepto de ciudadanía trae implícita la expectativa de continuidad de la comunidad nacional en el tiempo a través de las generaciones. Los niños y las niñas son, literalmente, el futuro de la nación. Este hecho también introduce una particularidad en su condición de ciudadanos. La generación adulta posee un poder de decisión provisional y acotado como guardiana temporal del patrimonio nacional (recursos naturales, históricos, sociales, culturales, espirituales), ya que debe considerar el interés que tienen las generaciones venideras en este legado. Entra en discusión el orden generacional, entendido como el patrón sistemático de relaciones entre generaciones definidas según criterios de edad y otros alusivos al ciclo vital. Dicho orden tiene que ser analizado desde la perspectiva de la equidad del reparto de poder, bienes y privilegios entre una generación y otra, similar a nuestros análisis de equidad y justicia en el orden de género, de clase y otros estructurantes de las sociedades contemporáneas.

Reconocer y hacer respetar los derechos ciudadanos de toda la población constituye un reto para cualquier Estado, incluso los más ricos. Para los países en desarrollo, entre ellos el Perú, el reto es especialmente grande. Conforme a una larga tradición en América Latina, la Constitución peruana expresa un conjunto de aspiraciones grandiosas en materia de derechos políticos, económicos, sociales y culturales. El crecimiento económico ha sido robusto en los últimos años, pero el Perú sigue siendo un país de ingreso medio y futuro incierto. Alrededor de un tercio de la población se halla en pobreza o pobreza extrema. No están dadas las condiciones para poder cumplir con muchas de las promesas constitucionales. Las políticas públicas suelen hacerse en base a las prioridades del momento y la postergación de muchos reclamos válidos.

Si bien es importante el contexto mayor, la vida cotidiana de los niños, niñas y adolescentes se desenvuelve en entornos locales. Los gobiernos locales tienen una gran capacidad para afectar la calidad de vida de sus residentes durante la infancia, la niñez y la adolescencia. Pueden (o no) crear parques, calles seguras, aire limpio, bibliotecas y actividades culturales, vivienda ordenada, centros escolares, protección contra depredadores, programas de salud, centros 
de cuidado diurno, clubes familiares, canchas deportivas y lugares de esparcimiento. La Ley de Municipalidades faculta a los gobiernos locales a actuar en todos estos planos pero no los obliga. De hecho, las condiciones físicas en las que crecen y se desarrollan los niños varían dramáticamente de un distrito a otro en el Perú. Para calificar las vastas diferencias de alguna manera, el Índice de Desarrollo Humano, usando los criterios del PNUD, va desde 0.788 en el distrito limeño de San Isidro hasta 0.323 en el distrito rural andino de Quillo (provincia de Yungay, región Ancash).

Al mismo tiempo, las condiciones de vida y sentido de derechos de los niños, niñas y adolescentes son determinados por la familia y el hogar en el cual nacen y crecen. Okin (1989) insiste en priorizar a la familia como laboratorio de aprendizaje de prácticas democráticas como el respeto por las opiniones diversas y la igualdad de derechos. El enfoque que adoptamos aquí concibe a los niños, niñas y adolescentes como individuos capaces de expresarse e intervenir en diversos asuntos usando medios que corresponden a su grado de madurez, lo que implica no solo hacer valer sus derechos, sino también ser conscientes de sus responsabilidades. Nos remite a reflexiones sobre la variedad de maneras de organizarse de las familias en el Perú (Anderson 2004). Los riesgos de privaciones económicas se concentran en las familias pobres, especialmente rurales, pero las familias pudientes no están exentas de otros tipos de riesgo. Aumenta la prevalencia de fármacos para combatir el déficit de atención y la depresión entre alumnos de colegios de élite. Hay niños criados por trabajadoras del hogar que, en un contexto de desigualdad y discriminación social, desarrollan sentimientos de afecto y dependencia frente a personas que, conforme crecen, aprenden a mirarlas como inferiores. Una realidad que comienza a visibilizarse es la cantidad de menores de edad que, en vez de recibir los cuidados prodigados por sus mayores, asumen el cuidado de padres, madres, abuelos y otros parientes discapacitados y enfermos (MIMDES-INEI 2010).

Por todo ello es preciso reconocer los intereses opuestos que forman parte de las relaciones entre las generaciones. En los países desarrollados, con generosos sistemas de seguridad social y poblaciones envejecidas que detentan un poder político grande, asoman los peligros de menoscabo de la inversión en la niñez. La misma tendencia comienza a manifestarse en América Latina, según un estudio de la Comisión Económica para América Latina y el Caribe, CEPAL (Rico/Delamónica y colaboradores 2010), sobre las transferencias públicas que benefician a la cohorte de adultos mayores versus la niñez y adolescencia. La limitada capacidad ciudadana de los no adultos es parte de la 
dinámica que subyace a esta nueva realidad. Confluye en ella la construcción cultural de la niñez como inocente de intereses políticos y materiales. Para gran número de hombres y mujeres en el Perú, los menores de edad necesitan ser protegidos, incluso de ellos mismos. Bajo estas condiciones, se camina lentamente hacia una conversación nacional acerca del rol, los derechos y los deberes de unos y otras.

El RECONOCIMIENTO LEGAL Y LAS ATENCIONES DEL ESTADO

El 36\% de la población peruana está conformada por niños, niñas y adolescentes de 0 a 17 años. De estos, el 45\% vive en condición de pobreza, según las estimaciones del estudio del Estado de la Niñez en el Perú 2011 (Benavides/ Mena/Ponce 2011).

MENORES DE EDAD EN EL PERÚ

\begin{tabular}{|l|c|c|}
\hline Población por grupos de edad & Nacional & $\begin{array}{c}\text { Porcentaje de la } \\
\text { población total }\end{array}$ \\
\hline Población total & $29,461,933$ & 100 \\
\hline Población de niños, niñas y adolescentes & $10,571,879$ & 36 \\
\hline Niños y niñas de 0 a 5 años & $3,546,840$ & 12 \\
\hline Niños y niñas de 6 a 11 años & $3,521,603$ & 12 \\
\hline Adolescentes de 12 a 17 años & $3,503,436$ & 12 \\
\hline
\end{tabular}

Fuente: Elaboración propia en base a Benavides/Mena/Ponce (2011).

El Perú ratificó la Convención Internacional sobre los Derechos del Niño en el año 1990. Uno de sus estipulados es el derecho que tiene todo niño y niña a la identidad. En el Perú, eso se traduce en el derecho a documentos como la partida de nacimiento y el documento nacional de identidad (DNI) de menores. Su carencia es prácticamente una sentencia a la invisibilidad y a quedar al margen de prestaciones estatales como el seguro universal de salud y los programas de protección social. Los mayores de edad pierden el derecho al voto y la posibilidad de acceder al sistema laboral formal.

Históricamente la población indocumentada ha estado repartida entre los estratos más pobres del país, tanto en las ciudades como en las áreas rurales, 
donde siempre ha habido menor acceso a estos documentos y a información sobre su importancia. Pero no siempre el problema se limita a la falta de accesibilidad o información. También quedan indocumentados muchos menores huérfanos, los que están bajo la tutela de personas con discapacidad y los que pertenecen a minorías étnico-lingüísticas. El Estado ha venido impulsando una fuerte campaña para reducir las brechas y es así que, al 2012, cerca del 90\% de niños, niñas y adolescentes están inscritos, ligeramente más varones que mujeres.

Las leyes nacionales traducen en hechos las ideas acerca de la protección debida a la niñez y adolescencia, así como aquellas acerca de las responsabilidades que deben asumirse en el proceso de su preparación para el pleno ejercicio de la ciudadanía. La legislación al respecto es frondosa; sólo podemos señalar algunos de los puntos álgidos. Vale mencionar que muchas de las normas son poco claras a nivel jurídico y poco consensuadas en la opinión pública. Una vez más, constatamos los conflictos que rodean los valores más preciados de cualquier sociedad: su niñez, su futuro y la manera de enrumbar hacia él.

La educación es obligatoria en el Perú hasta los 14 años o hasta completar 8 años de estudios básicos. Aunque existen notorios avances en el acceso a la educación, y la matrícula tanto de varones como mujeres (en la educación primaria se acerca al 100\%), aún prevalecen brechas entre las zonas urbanas y rurales. La educación secundaria está fuera de las posibilidades de muchos adolescentes pobres y rurales, y la cobertura de educación inicial recién ha alcanzado el 66\% de los niños y niñas de 3 a 5 años a nivel nacional. Discursivamente, el acceso a la educación se defiende como una preparación para la participación y contribución productiva, además de la realización personal, de los ciudadanos jóvenes.

Bajo la ley peruana, los padres, en forma mancomunada, asumen la responsabilidad de sustento, protección y educación de sus hijos e hijas hasta la edad adulta. Los abuelos pueden ser requeridos bajo determinadas circunstancias; por ejemplo, en casos en que el padre (con mucha menor frecuencia, la madre) haga abandono y deje de cumplir con sus obligaciones de alimentación. Los juicios por el pago de las pensiones alimentarias ocupan el primer lugar en la carga judicial pendiente. El Estado no interviene de oficio, sino que la madre (rara vez, el padre) debe iniciar y costear el juicio, en caso que uno de los progenitores faltara a su obligación.

Por costumbre, la mayoría de niños, niñas y adolescentes peruanos adquieren una o más parejas de padrinos que deben colaborar en la crianza y como guías espirituales. Ellos pueden asumir la custodia legal si los padres dejan de 
existir o bajo circunstancias excepcionales. Los menores cuya situación se determina como el desamparado moral y/o material en un juzgado de menores pueden ser remitidos a albergues estatales o instituciones religiosas suscritas al Instituto Nacional de Bienestar Familiar. Los procesos que llevan a este resultado son bastante azarosos, sujetos a los criterios de jueces poco preparados y con pocos recursos para la investigación. El seguimiento posterior y la posibilidad de apelación son escasos.

Según el artículo 20 del Código Penal, los menores de 18 años están exentos de responsabilidad penal, excepto en los casos de terrorismo en que la inimputabilidad baja a 15 años. El espectro del pandillaje, el abuso de sustancias, la delincuencia juvenil e incluso la utilización de menores como sicarios por los traficantes de droga está muy presente en la población, sin embargo. Existe un proyecto de ley que reduciría de 18 a 16 años la edad de inimputabilidad de los adolescentes que sean autores de delitos graves como homicidio simple y calificado, lesiones graves y culposas, secuestro, violación, hurto, extorsión y asociación ilícita para delinquir.

Entretanto, el voto es obligatorio en el Perú a partir de los 18 años. Se eligen autoridades y representantes locales, regionales y nacionales. Es requisito ser mayor de 18 años para ser elegido a un puesto de autoridad.

La política del Estado peruano frente a los niños, niñas y adolescentes se plasma en documentos oficiales cuya elaboración suele contar con la participación de actores no gubernamentales interesados en el tema. Está vigente el Plan Nacional de Acción por la Infancia y la Adolescencia (PNAIA) 20122021 y la Agenda Nacional y Descentralizada por los Derechos de la Niñez y la Adolescencia 2011-2016. Suscrita la Convención sobre los Derechos del Niño, el Estado peruano promulgó el Código de los Niños y Adolescentes (Ley $n^{\circ}$ 27337).

El PNAIA establece entre sus metas reducir al 5\% la desnutrición crónica en la primera infancia; que el $100 \%$ de los niños y niñas de 3 a 5 años accedan a una educación inicial de calidad; que el 70\% de los niños y niñas de segundo grado de primaria alcancen un nivel de comprensión lectora y razonamiento matemático suficiente; reducir la violencia familiar hacia los menores; reducir en un 20\% la tasa de embarazo adolescente; y lograr el acceso a una educación de calidad y la conclusión de la secundaria en la edad normativa. La Agenda Nacional y Descentralizada por los Derechos de la Niñez y la Adolescencia 2011-2016 refleja la preocupación de más de 45 organizaciones e instituciones que trabajan a favor del ejercicio pleno de los derechos de las niñas, niños y adolescentes en el Perú. Entre sus principales metas están el acceso 
universal al DNI de menores, la cobertura universal de vacunas preventivas, la reducción de la mortalidad infantil y materna y la protección a la niñez y adolescencia que trabaja.

Se observan temas comunes, particularmente álgidos, en ambos documentos, como la prevención de la violencia familiar y la educación eficaz y de calidad. La participación no forma parte de las metas emblemáticas del PNAIA, aunque es mencionada como uno de sus principios rectores; en cambio, éste es un tema sobre el cual se insiste en la Agenda Nacional, con una crítica al lento avance que se ha dado en la materia. Ambos documentos hacen énfasis en el acceso al documento de identidad y por tanto a la adquisición de los derechos como ciudadanos reconocidos por el Estado.

Uno de los retos que enfrenta el gobierno peruano es no sólo sostener el crecimiento económico alcanzado en los últimos años, sino, además, engranarlo con el desarrollo social y humano. En esta conexión, la salud, educación y bienestar de las nuevas generaciones son temas eje por un amplio consenso. Empresarios, gobernantes regionales, congresistas, maestros y médicos anuncian su preocupación. Sin embargo, el estudio panorámico de Vásquez, Mendizábal y colaboradores (2002) arroja dudas sobre la sinceridad de los anuncios y la capacidad técnica del Estado y sus socios privados y no gubernamentales de "poner a los niños primero". Uno de los índices que mejor refleja las ambigüedades de la situación es la persistente desnutrición infantil. Las grandes inversiones mineras y energéticas, el boom de la agroindustria, los yacimientos de gas natural recientemente descubiertos, la siembra de centros comerciales en todas las ciudades de la costa, sierra y selva: nada, al parecer, es capaz de reducir el tercio de menores de 5 años en el Perú que sencillamente no consigue comer lo que necesita para seguir una curva normal de crecimiento.

ENTRE LA DEPENDENCIA Y LA AUTONOMÍA, LA RESPONSABILIDAD Y LA LIBERTAD AMBIGUA

El conflicto que se plantea entre la protección a los menores de edad y la imposición de roles y responsabilidades adultas tiene expresiones sumamente agudas en el Perú. Ser niño o niña no garantiza protección; acceder a las responsabilidades adultas no siempre implica gozar de sus privilegios y prebendas. Existen dos ámbitos donde este conflicto es particularmente marcado. Uno es el del trabajo infantil y el otro concierne a la maternidad y paternidad adolescentes. A continuación exploramos estos dos escenarios y los dilemas que plantean. 


\section{Trabajo infantil $y$ adolescente}

Dada la extensión de la pobreza en el Perú, muchos adolescentes y aun muchos niños de ambos sexos, se convierten en proveedores de sus familias o asumen tempranamente su propio sustento. No se trata únicamente de una respuesta a la pobreza, ya que el trabajo es visto como una experiencia formativa en muchos sectores de la sociedad peruana. Paradójicamente, para otros, el trabajo infantil y adolescente está en la base de la transmisión intergeneracional de la pobreza. Desde esa perspectiva, el trabajo infantil y en menor medida el adolescente impediría la asistencia a la escuela, el buen rendimiento y el acceso, por tanto, a una preparación laboral que ofrezca la posibilidad de ingresos decentes. Rompiendo el eslabón del trabajo infantil, sostienen estos analistas, se evita que los hijos y las hijas repitan las desventajas y penurias de sus padres y madres.

La ley peruana prohíbe el trabajo a menores de 12 años. Desde esa edad está permitido en condiciones excepcionales de desamparo y necesidad. Para los adolescentes entre 14 y 17 años, el trabajo está permitido siempre y cuando no ocupe más de 6 horas diarias, no interfiera con los estudios escolares y las actividades que acarrea no constituyan un peligro moral y material. El censo de trabajo infantil y adolescente realizado por el Instituto Nacional de Estadística e Informática (INEI) en el 2008 halló que el 29,8\% del total de la población de 6 a 17 años (2.255.100 personas) "realizan una actividad económica". De éstas, ligeramente más de la mitad están por debajo de 14 años. Del total de niños y adolescentes trabajadores, $54,7 \%$ son varones y $45,3 \%$ son mujeres.

¿Qué argumentan las familias? Los niños y niñas deben mostrarse hacendosos y dispuestos a asumir con seriedad la obligación mancomunada de ser miembros de un hogar. A muchos adultos les espanta la idea de que sus hijos crezcan flojos y haraganes, que no entiendan el valor del dinero, que esperen ayudas de otros o, peor aún, que sean arrastrados en prácticas de robo y la explotación de otros como medio de vida. También figura en los cálculos de los padres y madres de familia su desconfianza frente a la escuela como canal de aprendizaje de una ocupación y otros conocimientos prácticos para la vida. El hecho que los hijos e hijas trabajen está relacionado con el nivel de educación de padres y madres, independientemente de los ingresos que haya en el hogar. A menor educación formal de los padres, mayor la probabilidad de que los hijos estén ganando dinero o colaborando en una empresa familiar.

Para muchos adolescentes, y no pocos niños y niñas, el trabajo resulta atractivo (Anderson/Minaya/Figueroa 2010). Se sienten orgullosos de co- 
laborar con sus familias, de poder cubrir sus propios gastos del colegio y ayudar en situaciones de emergencia como una enfermedad en la familia o las demandas de los hermanitos menores. Muchos concuerdan en el valor del aprendizaje, enfatizando la posibilidad de hacer un mapeo social (conocer cómo viven las clases pudientes, en el caso del trabajo doméstico) y acumular capital social para el futuro (Anderson 2007). Por último, el ingreso propio crea la posibilidad de comprar las zapatillas, entradas al cine y otros bienes prohibidos o de valor simbólico potente en las jerarquías adolescentes.

El trabajo infantil y adolescente está fuertemente asociado a la economía campesina de minifundio familiar en las regiones de la sierra andina y la Amazonía rurales. El hogar posee algunas chacras de cultivo, rebaños mixtos de animales que necesitan sacarse diariamente a pastear, se practica la crianza de animales menores y cultivo de huertos cerca a la casa, y están siempre presentes las pesadas tareas de la producción doméstica de alimentos, vestimenta y vivienda. Siempre según las encuestas del INEI, la tasa de actividad de menores de 6 a 17 años en las zonas rurales en su conjunto es del 47\%; en las zonas urbanas, del 14,2\%. En esos contextos resultan ajenas nociones como la "edad legal" para trabajar. Los criterios para diferenciar a los adultos de los niños no pasan por la edad cronológica sino por la capacidad, destreza, juicio y sentido de responsabilidad que manifiesta la persona (Molinero 2003).

En las ciudades, los niños, niñas y adolescentes trabajan como cobradores, niñeras, cocineras, meseros, ayudantes de cocina en restaurantes y puestos, vendedores ambulante de golosinas y DVD pirateados, lustrabotas, canillitas, vendedores en puestos o tiendas, electricistas, pintores, peones de construcción, costureras, bordadoras a domicilio, mensajeros, jaladores y pregoneras, ayudantes en servicios de pensión y entrega de almuerzos, en la venta callejera de alimentos, el lavado y cuidado de autos, entre otros "mil oficios". Muchos combinan dos o más actividades, incluso para dos o más empleadores y en dos o más lugares a la vez. Muchos están presentes en un domicilio, taller de producción o establecimiento comercial simplemente como un par de manos (y piernas) dispuestas a colaborar en lo que se necesite. Sus ocupaciones son, literalmente, indescriptibles; sin categoría conocida.

En un esfuerzo por vincular el trabajo con las oportunidades que se crean para cuando los menores de edad lleguen a la adultez, Cavagnoud (2006) examinó la relación entre el trabajo adolescente, los estudios escolares y los imaginarios del futuro. Llegó a una tipología que combina las estrategias económicas de las familias y las estrategias de vida de los adolescentes que trabajan. Hay los que colaboran en una actividad económica familiar sin remuneración; 
los que trabajan por su cuenta y solamente para solventar los gastos propios; y los que aportan al presupuesto del hogar realizando un trabajo fuera del marco familiar. Para ellos el trabajo no se contradice con los estudios escolares, incluso, puede servir como estímulo. Otros dos conjuntos de adolescentes trabajadores sacrifican oportunidades educativas en aras de atender necesidades económicas. Algunos -más varones que mujeres- son el sostén de sus familias. A otros, simplemente ya no les interesa seguir estudiando. Dejan la escuela porque sienten que los cursos no tienen sentido ni contribuyen a su proyecto de mejoría. Claro está que los adolescentes que se hallan en estos dos grupos tienen que desempeñarse en una actividad lo suficientemente lucrativa como para soportar las demandas familiares y sus propias expectativas. Típicamente realizan trabajos fisicamente extenuantes en horarios muy largos, bajo condiciones de fuerte subordinación.

El trabajo del hogar agrega capas mayores de complicación a lo ya visto. El servicio doméstico realizado por niñas y mujeres adolescentes forma parte de una larga tradición en el Perú. Un par de generaciones atrás, muchos varones también trabajaban como ayudantes domésticos, incluso como niñeros, antes de trasladarse a otras ocupaciones. No obstante, el peligro de quedarse atrapada en esta rama de actividad, la privación de oportunidades educativas y de desarrollo autónomo, y los riesgos de acoso y abuso sexual durante el servicio en una casa, son factores que atañen al género femenino de manera específica. El aumento que se viene produciendo en las tasas de actividad de las mujeres urbanas ha creado un vacío en los sistemas de cuidado de los hijos que está siendo llenado por niñas-niñeras que trabajan unas horas al día para sus vecinas y familiares (Anderson/Minaya/Figueroa 2010). Las mujeres adultas que antes absorbían gran parte de la demanda de trabajadoras del hogar están encontrando mejores oportunidades y dejando la posta a mujeres adolescentes. El trabajar en casa constituye la primera experiencia laboral de una pluralidad de mujeres en el Perú, sobre todo las niñas y adolescentes que migran desde los pueblos rurales hacia las ciudades.

\section{Maternidad y paternidad adolescentes}

La minoría de edad y los derechos recortados de los niños, niñas y adolescentes no se concilian fácilmente con la condición de un número importante de ellos: el volverse madre o padre, y el establecer un vínculo conyugal, antes de cumplir los 18 años. La edad de inicio de la actividad sexual es cada vez 
más temprana y aunque actualmente existe mucha información disponible, el embarazo es un resultado frecuente, dada la prohibición legal del aborto y las sanciones sociales y religiosas que acarrea. A nivel nacional, casi el 14\% de mujeres menores de edad está gestando o ya es madre. El hospital público especializado, la Maternidad de Lima, tiene un pabellón específico dedicado a adolescentes embarazadas y parturientas. Ahí se atienden en promedio 4.000 embarazos adolescentes anualmente. Las jóvenes madres reciben consejería que enfatiza por un lado la necesidad de que el padre se involucre en la atención, manutención y relación con el bebé y, por el otro, la prevención de nuevos embarazos.

Irónicamente, el Perú tiene una legislación draconiana que intenta desconocer la sexualidad de los adolescentes. El Código Penal de 2006 penaliza las relaciones sexuales consentidas entre menores de 14 a 18 años. Los hospitales tienen que reportar a las fiscalías las menores de edad embarazadas o que buscan atención prenatal. Los padres de los bebés no se atreven a acompañar a sus parejas ni a veces firmar la partida de nacimiento de sus hijos porque pueden ser acusados de un delito -la violación de menores- cuya pena es 25 a 30 años de cárcel. Las farmacias no pueden dar información sobre métodos anticonceptivos ni expender anticonceptivos a menores de edad sin incurrir en fomentar un delito. Entretanto, casi el 20\% de los adolescentes de entre 13 y 15 años ya inició su vida sexual.Vale mencionar que existe un pedido ante el Tribunal Constitucional para declarar la ley en cuestión inconstitucional y violatoria de los derechos de los adolescentes.

Las leyes también intentan retrasar el ingreso a la vida conyugal a través de las estipulaciones acerca de la edad de consentimiento para casarse. Los menores de edad que decidan contraer matrimonio necesitan el consentimiento expreso de sus padres o tutores, so pena de perder el derecho de gozar de la posesión, administración, usufructo, gravamen o disposición de sus bienes hasta alcanzar la mayoría de edad. Siendo las uniones informales casi tan comunes en el Perú como los matrimonios formales, no es sorprendente que la mayoría de las parejas en donde uno o los dos son menores de edad opte por la convivencia. Para la mayoría, entonces, la ley sobre la edad de consentimiento es simplemente irrelevante. Refuerza su percepción de la lejanía del Estado y la necesidad de buscar protección y apoyo en otros lados.

El embarazo en niñas y adolescentes coloca sobre el tapete los riesgos biológicos de la tenencia precoz de hijos y el calibre de los servicios de salud que están al alcance de los niños, niñas y, sobre todo, adolescentes que se embarcan en una vida de responsabilidad autónoma de sus cuerpos y bienestar. Mucho 
se ha escrito en el Perú (por ejemplo, La Rosa 2001) sobre la salud sexual y reproductiva de los adolescentes. Ellos obtienen la mayor parte de su información al respecto de fuentes como los pares y los medios de comunicación, hecho que refleja la desconfianza que marca sus relaciones con el sistema de salud y los proveedores oficiales. Ponen en duda la confidencialidad de la consulta y sus derechos como usuarios a una atención discreta, respetuosa y efectiva.

La formación de parejas, con un proyecto de compartir la vida y establecer un hogar propio, suele tener un componente de rompimiento con la dependencia frente a los padres y apoderados. El embarazo adolescente puede convertirse en un medio, en el símbolo de esta transición, o en la motivación inmediata para dar el paso. En las tradiciones culturales asociadas a los Andes y los grupos nativos amazónicos, este significado emerge con claridad.

En las comunidades quechuas y aymaras de los Andes, el llamado "matrimonio de prueba" o servinacuy era el anuncio de la intención de la joven pareja de unirse al mundo adulto, anuncio que, hasta épocas recientes, solía asegurar cierto apoyo de los familiares de ambos y de otros miembros de la comunidad. Oliart (2005) pone en cuestión la vigencia de esta figura y retrata una situación de creciente desigualdad entre las adolescentes y sus pares varones en las comunidades andinas rurales. Actualmente los varones tienen más oportunidades que las mujeres para salir de la comunidad y estudiar o trabajar en ciudades como Cuzco, donde absorben las expectativas urbanas frente a la sexualidad, el matrimonio y la pareja. Para ellos, iniciar una relación sexual con una adolescente en la comunidad ya no acarrea la obligación moral de asumir la paternidad y proceder a establecer un hogar en caso de un embarazo. Para las adolescentes, esas obligaciones mantienen su vigencia. El resultado es un aumento del madresolterismo en las comunidades rurales y el cierre de las oportunidades educativas y personales para muchas adolescentes y jóvenes. A diferencia de antes, ellas incurren en un madresolterismo estigmatizado que fácilmente lleva a la tenencia de hijos posteriores con una sucesión de padres, cada uno menos dispuesto que el anterior a compartir las responsabilidades económicas de su conducta. Los varones se escapan a las sanciones que se les hubiera aplicado en años anteriores; incluso, se convierten en modelos de cierto prestigio para los niños y adolescentes más jóvenes.

En las ciudades, sobre todo en los sectores urbanos populares, tener un hijo siendo adolescente trae consigo una serie de significados y consecuencias igualmente complicadas. Olthoff (2006) explora las ambigüedades a partir de un fino trabajo de campo en un barrio emergente de la zona sur de Lima. 
Esta autora señala los esfuerzos de los padres por controlar el comportamiento de sus hijas adolescentes, que se expresan en dos mandatos repetidos hasta el cansancio: "cuídate" y "sé profesional". El control no disminuye conforme avanzan hacia la mayoría de edad; por el contrario, mientras mayor sea la adolescente, mayor es el peligro de involucrarse en una relación sexual (es decir, no "cuidarse") que termina frustrando sus esperanzas de graduarse del colegio secundario y acceder a una formación terciaria ("ser profesional", aunque fuere con una especialización técnica). Las adolescentes comparten esas aspiraciones pero están expuestas a las presiones sociales y el deseo propio de explorar relaciones con los chicos en su entorno. En los hechos, un buen número se embaraza y abandona el colegio (aunque luego pueden volver). Olthoff acota que eso ocurre generalmente con las adolescentes mayores, cercanas a los 18 años. Por lo general, los padres de sus bebés, otros adolescentes, reconocen su condición y hacen esfuerzos por cumplir. Algunos se emocionan y se alegran con la idea de fundar una familia e iniciar una convivencia en un cuarto en el techo de una de las casas de los padres o en una habitación alquilada en algún lugar del barrio. Los problemas aparecen después, cuando se hace patente el tamaño del reto de sostener económicamente a la nueva familia y atender a un bebé. Muchas de las parejas no sobreviven más que unos cuantos meses.

Olthoff relaciona estas situaciones con el tránsito a la adultez que hacen las adolescentes, no según criterios legales sino a los ojos de sus familiares, comunidades y a los suyos propios. Su estatus en la familia cambia: de hijas dependientes, pasan a ser integrantes independientes con sus propias responsabilidades maternas. Producido el desastre, no tiene sentido ejercer sobre ellas la vigilancia de antes aunque algunas encuentran que el control de los familiares pasa a ser ejercido por un novio celoso. No obstante, para otras, se abre un panorama de autonomía económica y decisión sobre sus movimientos, vestimenta, vínculos sociales y actividades de participación (Olfhoff 2006: 234). Buitrón (2003), en un estudio retrospectivo, recoge expresiones de satisfacción con el rol materno, incluso en ausencia del apoyo de una pareja, entre mujeres adultas que se convirtieron en madres adolescentes. Incluso, entre "familias" de niños y adolescentes que viven en situaciones de marginalidad extrema en la calle, el convertirse en mamá o papá tiene connotaciones positivas, de transitar hacia un rol de responsabilidad, seguridad y estabilidad (Figueroa 1996).

Es en la Amazonía donde se hallan las situaciones más problemáticas con respecto al simbolismo del ingreso a la adultez y a la vez riesgos palpables para 
el bienestar y desarrollo de la niña o adolescente que inicia un embarazo o entabla una relación conyugal (Heise/Landeo del Pino 1996). La tasa global de fecundidad en la Amazonía es de 7,9 hijos por mujer, más del doble del promedio nacional $(3,4)$. De acuerdo con el Censo Nacional del 2007, el $21,8 \%$ de las adolescentes indígenas entre 15 y 20 años tiene por lo menos un hijo. Entre las mujeres asháninka (etnia amazónica más numerosa del Perú) el $44 \%$ ya es madre a esa edad. Bajo las instituciones tradicionales de las sociedades amazónicas, adquirir una esposa era un paso imprescindible para que los varones accedieran al estatus de hombre adulto. Permitía al buen cazador hacer gala de sus dotes, alimentando las redes de intercambio entre las unidades domésticas y mostrándose generoso con sus aliados y visitantes. Había una fuerte presión sobre los hombres para adquirir cuñados y yernos, aun cuando eso implicaba concertar matrimonios para sus hijas y hermanas a tierna edad. ¿Cuánto de eso persiste en el patrón actual de embarazo y uniones precoces en la Amazonía y cuánto pesa la falta de oportunidades de vidas alternativas para las niñas y adolescentes mujeres? Lo suficiente para merecer una atención especial.

LA PARTICIPACIÓN CIUDADANA Y LAS AGENDAS POLÍTICAS DE LOS NIÑOS, NIÑAS Y ADOLESCENTES

Los signatarios de la Convención Derechos del Niño aceptan la obligación de fomentar mecanismos de participación de los menores de edad en las decisiones políticas. Eso implica proveer educación cívica en las escuelas y establecer mecanismos de consulta, incluso parlamentos infantiles. Implica tratar la educación de niños, niñas y adolescentes como una experiencia que debe prepararlos para la participación cívica, política y económica. En esta sección exploramos hasta qué punto estas ideas han calado en el Perú y qué cambios han introducido en la agenda política nacional. Un problema persistente es asegurar que la participación e incidencia de los menores de edad sean autónomas.

Lo que conocemos hoy como participación ciudadana se comienza a presentar de manera más clara en el Perú, a partir de la década de 1980, cuando el último gobierno militar cedió ante un régimen civil elegido, por primera vez, con los votos de la población analfabeta. La Constitución de 1993 ratificó el derecho universal de los ciudadanos mayores de 18 años a elegir, revocar y demandar la rendición de cuentas de sus autoridades y representantes (Remy 
2005). El PNAIA 2012-2021 especifica sus alcances para el caso de los menores de edad:

[Es] un derecho y un proceso que les permite a las niñas, niños y adolescentes ser actores de su desarrollo personal y social. Ello implica el ejercicio del derecho a ser informado, emitir opinión, ser escuchado, organizarse e incidir en las decisiones que se toman en temas que le involucran o interesan, teniendo en cuenta siempre los principios de no discriminación, la autodeterminación progresiva y el interés superior del niño (Ministerio de la Mujer y Poblaciones Vulnerables 2012: 31).

El enunciado permite vislumbrar cómo la participación de los menores sirve una doble finalidad: incorpora (dentro de parámetros que fijan los adultos) sus propuestas y deseos en los procesos políticos y simultáneamente instruye y ejercita a los niños, niñas y adolescentes en las prácticas de participación legitimadas en la sociedad peruana.

Hart (1993), entre otros estudiosos, diferencia los niveles de participación de los niños, niñas y adolescentes y llama la atención sobre los riesgos de su manipulación. Las caras patéticas de niñas y niños pobres son utilizadas rutinariamente en el Perú para respaldar campañas de recaudación de fondos o para alentar el pago de los impuestos; esto sería un ejemplo de los niveles inferiores y formas bastante cuestionables de participación según Hart. En el nivel máximo están los proyectos que emergen como una iniciativa de los niños en los cuales ellos ejercen la potestad de invitar o no la concurrencia de los adultos. En los rangos intermedios de la escala se ubican las distintas estrategias que implican informar a los niños, niñas y adolescentes acerca de las implicancias para ellos de determinadas medidas y políticas, consultar sus opiniones e involucrarlos en proyectos que nacen por iniciativa de los adultos.

El peligro es limitar las formas de expresión de la participación infantil y adolescente a los cánones conocidos y desconocer -incluso invisibilizarformas de expresión que pueden ser particularmente cómodas para los no adultos. Las formas aceptadas serían los comités consultivos, las asambleas, las votaciones, las plataformas expresadas en discursos y panfletos y otros similares que implican un manejo cuasi adulto de la escritura, argumentación y razonamiento lineal. Otras expresiones corren el riesgo de confundirse con expresiones de protesta, de contestación frente a la autoridad adulta o de conductas que bordean con rupturas de la tranquilidad pública y la destrucción de bienes ajenos. Existen movimientos juveniles de grafiteros, raperos, breakeros y rockeros que canalizan los sentimientos y deseos de la población adolescente. Los adolescentes y jóvenes utilizan los blogs, Twitter, la radio y, 
en ocasiones, la fotografia y el cine para colocar sus puntos de vista. Ayacucho, epicentro de la violencia política de los años ochenta, es una fuente excepcional de creatividad en ese sentido (Huber 2002; Durand 2007). Aquí, como en otras partes, se mezclan símbolos y prácticas prestados de la cultura juvenil internacional, la cultura urbana dominante y las culturas originarias peruanas.

Es en las escuelas peruanas donde hallamos institucionalizados los mecanismos de participación más claramente al alcance de la masa de población infantil y adolescente. Las defensorías y los municipios escolares datan de hace un par de décadas y deben crearse en escuelas públicas y privadas, en los gobiernos locales y en organizaciones de la sociedad civil. Las propuestas de los alumnos que forman parte tocan cuestiones de limpieza, orden y salud en los colegios: colocar un botiquín, reciclar los residuos, mejorar las condiciones para la prevención de accidentes.

Otro canal abierto es la participación en los gobiernos municipales provinciales y distritales; por ejemplo, en las deliberaciones públicas que dan lugar al presupuesto participativo. Parte de un movimiento que ha recorrido América Latina entera, los presupuestos participativos convocan a la presentación de proyectos por parte de grupos organizados que compiten por el uso de los fondos de inversión de los gobiernos locales. Un caso notable es el de la Municipalidad de Ventanilla, distrito de Callao (ciudad-puerto contigua a la capital, Lima), donde un porcentaje del presupuesto participativo es asignado a los niños, niñas y adolescentes. En 2010 se desarrollaron dos proyectos, uno dedicado a mejorar el ambiente y otro, a la reinserción social de jóvenes pertenecientes a pandillas y con problemas de alcohol y drogas. En 2011 se eligió un proyecto dirigido a ampliar la oferta de herramientas tecnológicas y académicas en las escuelas. Otro caso ejemplar es la Municipalidad de Miraflores a través de su programa Ciudad de los Niños, que pretende tomar en cuenta las perspectivas de los menores de edad en el mejoramiento de la infraestructura, los servicios y la convivencia en ese distrito residencial y comercial de Lima. En la ciudad surandina de Arequipa, el municipio distrital de José Luis Bustamante y Rivero confió, con éxito, a una organización de jóvenes impulsar un proyecto de prevención de drogas y la promoción del liderazgo de los adolescentes y jóvenes (Cusirramos 2005).

La protección del ambiente, el mejoramiento de la educación, acciones contra la violencia familiar y los castigos extremos a los niños y niñas son algunos de los puntos en agenda que articulan los niños, niñas y adolescentes peruanos. La provisión de canchas deportivas, bibliotecas y ludotecas, y el auspicio a festivales y actividades culturales también aparecen. Otros reclamos 
son algo más velados o localizados: el respeto por el trabajo infantil y la protección de participar en conflictos armados o actividades ilícitas (narcotráfico, reclutamiento forzoso en los remanentes de grupos terroristas). Una demanda que emergió claramente en los parlamentos infantiles que fueron impulsados por la ONG Rädda Barnen durante varios años, debe haber sorprendido a más de uno: los niños, niñas y adolescentes elegidos como representantes de sus pares en todo el país criticaron duramente la corrupción de los políticos, instituciones gubernamentales y grupos de poder. Queda claro que tomar seriamente en cuenta los reclamos de los ciudadanos menores de edad en el Perú llevaría a cambios que muchos no están dispuestos a contemplar.

\section{LA DIVERSIDAD CULTURAL}

Un número importante de niños, niñas y adolescentes peruanos pueden sustentar el derecho a una identidad propia y lugar propio dentro de una nación pluricultural -tal como se autodefine la nación peruana- en base a su pertenencia a un pueblo indígena o grupo (como los afrodescendientes) reconocido como parte de la diversidad cultural del país. Según el Censo Nacional del 2007, 4.045.713 personas mayores de 3 años aprendieron a hablar en una lengua distinta al español. Los niños, niñas y adolescentes entre 3 y 17 años que tienen una lengua materna originaria son 1.046.639. Dada la velocidad de pérdida de estas lenguas en la generación joven, los que podrían reclamar una identidad "diversa” serían fácilmente el doble de ese número.

La pieza clave en este ámbito es la educación intercultural bilingüe. Se trata de una educación que reafirma el valor y la pertinencia del legado cultural de cada grupo y que a la vez prepara a los niños, niñas y adolescentes a tomar su lugar en proyectos diversos de desarrollo. De ellos depende la innovación y adaptación a nuevas condiciones sociales, políticas y ambientales que afectarán sus modos de vida (Tomasevski 2003). En el caso de los niños y niñas indígenas, amazónicos y andinos, el panorama se complica debido a la renuencia a trabajar en zonas alejadas por parte de profesores calificados y, en algunos lugares, la poca aceptación que tienen los padres hacia un sistema que les puede parecer ajeno, poco útil y hasta contraproducente. Todo esto crea un escenario adverso para la población indígena infantil y adolescente. Las cifras obtenidas en la Evaluación Censal de Estudiantes en Lenguas Originarias en 2008 consignan que el 96\% de los alumnos no lograron los aprendizajes esperados para el grado cursado en comprensión de textos escritos en su propia lengua. 
Las desigualdades al interior de la población "diversa” también son notorias. Así, mientras que el 68\% de los jóvenes aymaras, en el sur andino, concluyen la educación secundaria entre los 18 y 20 años, en el caso de los asháninka de la selva central, solo lo hace el $14 \%$.

En las comunidades andinas y amazónicas los mundos de los adultos y los niños se entremezclan en la vida cotidiana y se encuentran en rituales que dificilmente se replican en las ciudades. Al hablar del embarazo adolescente y los significados del matrimonio señalamos algunos de los modos de concebir y vivir estos hechos en segmentos de la sociedad peruana que recorren procesos culturales diferentes. Una exploración similar podría hacerse frente al trabajo y los roles económicos de adultos y niños, frente a la responsabilidad moral que se imputa a personas no adultas (según la concepción de cada grupo), frente a la participación política y el liderazgo, frente a las prácticas religiosas y los cuidados de la salud. Las diferencias son fuertes pero, hasta cierto punto, pueden llevarse en paz gracias a la repartición de las zonas de influencia. Los grupos nativos amazónicos viven concentrados cada uno en su territorio y, cuando salen de éste, saben camuflarse o mimetizarse con la sociedad mestiza dominante. Los campesinos andinos han aprendido a minimizar sus reclamos de autonomía cultural y plantear estrategias propias bajo un lenguaje de "informalidad" que exige la no interferencia pero suspende las definiciones finales.

Dicha situación conlleva sin duda innumerables injusticias y experiencias dolorosas para los adultos "diversos". Los niños, niñas y adolescentes viven expuestos a los insultos, apodos y a la discriminación cotidiana en la escuela, la calle y -como se ha visto en casos muy comentados y rotundamente condenados recientemente en Lima- los cafés, cinemas y discotecas. Sin embargo, las manifestaciones más graves de las desigualdades que recorren el sistema de relaciones interétnicas en el Perú se presentan en situaciones en que la protección debida a la niñez vulnerable se convierte en un atropello a los derechos civiles, la autonomía personal, la autodeterminación de los grupos y la diferencia cultural. Aun hoy pueden escucharse propuestas de retirar a los hijos de los indígenas amazónicos del poder e influencia de sus padres a fin de "civilizarlos". Pueden hallarse menores de edad indígenas en cárceles acusados de actos que no son crímenes en sus comunidades. Existen juzgados de paz y de familia que malinterpretan las palabras y deseos de los usuarios indígenas. Y en casos como la violencia doméstica ejercida contra menores o que afecta su vida familiar, incluso en casos de violación sexual, las instancias correspondientes se mantienen pasivas, apelando a "la costumbre" de los pueblos de pertenencia de la víctima o su victimario (Paredes 2005). 


\section{Conclusiones}

El Perú tiene una agenda pendiente muy larga hasta llegar a darle un contenido real a lo que es ser ciudadano del país. La inclusión social, declarada un objetivo fundamental del actual gobierno, ha sido largamente postergada. La ciudadanía cobra sentido cuando se siente parte de un país y sus procesos de decisión día a día. Las historias de exclusión pesan fuertemente en el Perú y siguen habiendo muchos hombres y mujeres cuyo involucramiento se reduce al ejercicio a regañadientes del voto obligatorio cada tantos años. Sus hijos, niños, niñas y adolescentes, deben revertir estas situaciones.

Aspiramos a que las niñas y niños incorporen la participación y el ejercicio de formas de ciudadanía como parte de sus vidas cotidianas. Deben estar habituados a opinar sin vergüenza ni temor, a dar y recibir, a juntarse con sus pares en comités fugaces y organizaciones permanentes, a "jugar a la democracia" como juegan a la tiendita y la casita, a apropiarse de espacios y ocasiones que ratifiquen públicamente sus derechos y reclamos frente a la colectividad. Ideal sería que cada individuo a lo largo de su vida cuente con una "caja de herramientas" que le permita desenvolverse como ciudadano de modos concordantes con sucesivas coyunturas y situaciones de vida. En la niñez, la atención y el amor de los padres y familiares, una buena educación, salud y vivienda digna, ejemplos de tolerancia, el fomento de la capacidad para imaginarse en los zapatos del otro, son algunas de esas herramientas básicas. En cambio, crecer acostumbrado a la indiferencia, las carencias, y tomado por las urgencias de hoy, reduce las expectativas, ahoga la criticidad y anula la capacidad de protesta, necesarias en toda comunidad política. El Perú no está en ese camino; ya no tiene por qué conformarse con tan poco, tan mal distribuido, como alguna vez algunos pueden haber pretendido.

Muchas instituciones en el Perú expresan un pasado de poco reto, poca competencia y mucho acomodo. En ese contexto, no es sólo una cuestión de derecho sino una cuestión de sobrevivencia lo que los niños, niñas y adolescentes tomen posesión de las instituciones que pretenden estar a su servicio (escuelas, programas familiares, infraestructura local) y que tengan cada vez mayor incidencia en otras. El Perú tiene una larga tradición de importar políticas, formatos institucionales y tecnologías sociales. ¿Cómo puede romperse ese hábito, desalojando el facilismo y la profunda inseguridad que esta práctica delata? Los adolescentes y jóvenes son la clave en muchos proyectos nacionales del mundo en desarrollo precisamente por su disconformidad, irreverencia e idealismo. 
Por todo lo dicho, las propuestas a futuro implicarán extender las facultades y derechos a los niños, niñas y adolescentes en un marco de ciudadanía multigeneracional (Van Bueren 2011) y, además, intercultural. Traducir estas palabras en realidades nos compete a ciudadanos, mayores y menores. 


\title{
INACABADAS. ETNICIDADY CIUDADANÍAS SUSTANTIVAS EN MÉXICOY PERÚ
}

\author{
Sofia Venturoli \\ Francesco Zanotelli
}

DiFERENTES CIUDADANÍAS Y DIFERENTES RECONOCIMIENTOS ${ }^{1}$

La lucha de los movimientos indígenas en América Latina en los últimos veinte años, ${ }^{2}$ batallas desarrolladas a niveles locales, internacionales y globales, engendradas sobre demandas de derechos decisionales y de autodeterminación política, cultural y social ¿se podrían resumir simplemente en una demanda de ciudadanía? Quizás todavía no estamos en condición de responder unívocamente a esta pregunta; sin embargo, resulta útil detenerse sobre estas cuestiones, ya sea en contextos teóricos generales, ya en análisis específicos de estudios de caso. Primero necesitamos reflexionar sobre el concepto de ciudadanía y cómo se vincula hoy con las categorías étnicas, cómo el concepto de ciudadanía se expande y se contrae en relación al concepto de etnicidad.

1 "Diferentes ciudadanías y diferentes reconocimientos", la primera mitad escrita por Venturoli; la segunda, por Zanotelli; "Etnicidad negociada y ciudadanía estratificada: un caso desde los Andes de la sierra de Ancash, Perú", escrito por Venturoli; "Ciudadanía sustantiva y etnicidad en movimiento: procesos desde el México contemporáneo”, escrito por Zanotelli; "Reflexiones finales", la primera mitad escrita porVenturoli; la segunda, por Zanotelli.

2 Véanse, entre otros, Kuper (2003); Jackson-Warren (2005); De la Cadena/Starn (2010). 
Tenemos que preguntarnos qué significa ciudadanía en contextos étnicamente definidos -o indefinidos- y si la etnicidad es siempre el punto de partida de los discursos políticos de muchos movimientos indígenas o, si en algunos casos, no será el punto de llegada. ¿Resulta hoy la etnicidad una herramienta funcional a la lucha para la ciudadanía o tórnase un obstáculo al pleno fruir de la ciudadanía?, ¿y cuál tipo de ciudadanía?

En el léxico de Marshall, ${ }^{3}$ ciudadanía ya no es solamente un cartel identificativo de la nacionalidad de un individuo, sino que incluye todos los indicadores necesarios para identificar la relación efectiva entre el individuo y la sociedad de la cual participa; es un uso del término ya no axiológicamente neutro, sino éticamente y políticamente saturado (Costa 2005). Ciudadanía como opuesto de sujeción, donde todos los individuos son iguales desde el punto de vista de los derechos en una relación activa con la sociedad y el Estado que, típicamente, se refiere a un sentido de pertenencia a una comunidad política, vinculado a una serie de derechos y que designa una relación entre un individuo y el Estado. Estas relaciones se construyen sobre normas políticas definidas oficialmente a nivel jurídico y constitucional, así como sobre prácticas cotidianas de los individuos y grupos pertenecientes a aquella comunidad. Sabemos que en varios casos, no solamente latinoamericanos, las normas reconocidas por la comunidad no necesariamente se reflejan en acciones en la vida de la comunidad; es decir, la ciudadanía formal no corresponde a una ciudadanía sustancial. Marshall revindicaba una tensión hacia la igualdad, una sociedad donde las diferencias de clases existen pero cooperan para el beneficio común de todos hacia una nivelación de las diferencias agudas (Marshall 1950). Críticas recientes al pretexto de universalismo de la ciudadanía democrática enseñan cómo ésa no es renuente a acoger persistentes discriminaciones y mecanismos de dominios construidos, sobre todo, alrededor de categorías como etnia y genero, ${ }^{4}$ pues la ciudadanía así como ha sido vislumbrada, se refiere y se construye sobre una específica imagen de individuo (Mezzadra 2002): hombre, europeo, blanco. La narrativa de la ciudadanía ha sido muy a menudo usada como herramienta de gestión de los intereses de los grupos dominantes: "the discourse of citizenship has rarely provided a neutral framework for resolving disputes between the majority and minority groups" (Norman/Kimlicka 2000: 11). El paradigma del multiculturalismo nace, supuestamente, para deconstruir estas formulas excluyentes,

3 Sobre ciudadanía marshaliana véase la Introducción a este volumen.

4 Véase la Introducción a este volumen. 
es decir, para ampliar los confines ${ }^{5}$ de la ciudadanía y redefinir sus contenidos, sin embargo es un paradigma que alumbra las diferencias y construye otros confines. En el subcontinente latinoamericano el reconocimiento oficial de carácter multicultural de los Estados es un hecho constitucional en varios casos. Considerando la ciudadanía multicultural, en términos de modelos políticos, y su relación con el interculturalismo, en términos de modelos de vida social entre individuos, Kymlicka (2003) individua en el vínculo entre estos dos polos el núcleo central de la construcción de diferentes ciudadanías que se asientan sobre diferentes imágenes de la naturaleza del Estado, así como diferentes imágenes del individuo. El principio fundante de un Estado multicultural debe buscarse en el rechazo de la idea que el Estado es la posesión de un solo grupo nacional. Secundariamente, el Estado multicultural repudia aquellos procesos de construcción de la nación que se inspiran en ideales de asimilación o de exclusión de subgrupos nacionales. Un Estado que se proclama multicultural acepta, y promueve, la completa participación de todos los ciudadanos en las instituciones, en la vida política sin tener que negar o esconder su identidad étnico-cultural (Kymlicka 2003: 150).

Sin embargo, ¿es una ciudadanía multicultural o una ciudadanía étnica la que demandan los movimientos indígenas latinoamericanos? (Bello 2004). ¿Es una ciudadanía diferenciada en base a culturas, etnias, etc., un tipo de ciudadanía que pueda mantener aquella tensión, marshalliana, hacia la igualdad? Hay que considerar la idea de ampliación de los confines -que nos parecía a primera vista la idea principal de las luchas de los movimientos indígenas en América Latina- y de los contenidos, pues la ciudadanía étnica hay que entenderla como "una forma de ciudadanía restrictiva que reconoce a los grupos étnicos, les restituye bienes simbólicos y materiales, le otorga canales de participación, pero no se hace cargo del resto de la sociedad" (Bello 2004: 201). La ciudadanía étnicamente construida es una idea de ciudadanía que redefine la relación entre individuo y Estado, y comienza a considerar otro tipo de relación: aquella entre grupos y Estado "para pensar el grupo como sujeto social interpelado y titular de derechos y deberes" (Bello 2004: 186). Es decir, una forma de ciudadanía específica y limitada a contextos socioculturales precisos, así como a momentos históricos determinados que, de una forma, habilita varias ciudadanías, o sea, ciudadanías con diferentes identidades, exponiendo aún más la paradoja de la igualdad de todos los ciudadanos. Si la ciudadanía no es solamente un cierto estatus definido por una serie de dere-

5 Sobre confines y ciudadanía, véase Mezzadra (2007). 
chos y responsabilidades, sino también una expresión identidaria compartida de pertenencia a una comunidad política, la idea de ciudadanías diferenciadas ¿no es una contradicción en términos? ${ }^{6}$ Igualmente, si la ciudadanía es una herramienta para un equivalente trato de todos los individuos, con derechos uniformes frente a la ley, las ciudadanías diferenciadas ¿no nos llevan atrás en nuestro camino hacia la igualdad? Además, cuando mencionamos el término 'identidad' nos encontramos en el medio de dos polos: ¿estamos hablando de una identidad nacional común que identifica una comunidad política en la cual los miembros actualizan una ciudadanía compartida o hablamos de varias identidades presentes en la misma comunidad, todas meritorias de específicas ciudadanías, en un contexto multicultural y pluralista?

Considerando que las ideologías asimilacionistas del Estado homogéneo han sido superadas y han mostrado todos sus límites y problemáticas, la construcción de nuevos confines ¿no puede ser un riesgo? ${ }^{7} \mathrm{Si}$ el paradigma del multiculturalismo nace como respuesta progresiva de una critica al modelo de ciudadanía homogeneizante, hay también que subrayar que el multiculturalismo aparece muy a menudo como una respuesta débil, que pone énfasis principalmente en los derechos individuales de ciudadanos pertenecientes a minorías culturales dentro de un Estado-nación. Aunque el multiculturalismo constituye una etapa fundamental en las reformas constitucionales avanzadas en términos de derechos indígenas en lo que concierne a América Latina- no presupone la idea de un derecho colectivo, y sus efectos se pueden circunscribir en el ámbito cultural. En el caso latinoamericano el paradigma multicultural es criticable en la propuesta y en la práctica política, sobre todo porque en diferentes contextos, ya sea desde el punto de vista demográfico, ya sea del político, los grupos indígenas rechazan la idea de considerarse "minorías" dentro un Estado "mestizo". A este propósito, Burguete Cal y Mayor (2010) examinan el conflicto entre el paradigma del multiculturalismo y las autonomías étnicas, el primero mayormente orientado hacia un reconocimiento individual de la ciudadanía diferenciada; el segundo más vinculado a practicas políticas, económicas y culturales colectivas dentro de un diferente concepto de ciudadanía. Uno de los problemas contemporáneos que atañe a la relación entre el concepto de etnicidad y el de ciudadanía es que, tanto en la historia

Véase Kimlicka/Norman (2000); Kimlicka (1996).

7 Véase la categorización de Marion Young (1990) de ciudadanías diferenciadas y también la categorización que se encuentra en Norman/Kimlicka (2000: 18). Para una clasificación de los diferentes derechos diferenciados reclamados por diferentes minorías, véase Levy (1997). 
política de América Latina, como en la definición interna de los diferentes grupos de sus habitantes, la pertenencia al territorio nacional no se construye en una relación directa y diádica entre individuo y Estado, sino a través de diferentes estratificaciones ('corporaciones') basadas en el reconocimiento del individuo dentro de los proyectos nacionales no de forma directa sino según su adscripción a grupos intermedios. Esta cuestión produce a menudo conflictos entre dos visiones del derecho muy divergentes (Holder/Cortansell 2002), la individualista o liberal y la colectivista-corporativa. La primera no excluye los derechos corporativos, sino que los entiende como instituciones destinadas a preservar el Estado y los derechos individuales de sus integrantes, así como es normal en el paradigma liberal individualista. La segunda posición subordina el individuo al grupo, considerando que su bienestar viene de su integración dentro de la 'corporación'. El punto de vista indígena en torno a estas dos 'escuelas jurídicas' es mucho mas pragmático, ya que se pone a discutir a partir de situaciones muy concretas que atañen a su pueblo y a los demás pueblos indígenas del mundo, como por ejemplo el derecho a gestionar la decisión sobre el uso de los recursos naturales por parte del Estado cuando éstos caen dentro del territorio indígena. El punto de vista indígena busca la convivencia entre las dos filosofias jurídicas, siendo que el derecho individual y el colectivo pueden convivir a través de la practica (cfr. Holder/Corntassel 2002).

En el caso latinoamericano, las instancias de reconocimiento de las diferencias incluyen una demanda de inclusión en la sociedad nacional; la solicitación de derechos multiculturales y derechos diferenciados de representación, a menudo, nace de falta de inclusión y reconocimiento, y la afirmación de las diferencias facilita la inclusión y no viceversa. ${ }^{8}$ Quizás deberíamos razonar con una idea de equivalencia más que de igualdad; es decir, eliminar del concepto de igualdad el impulso a la homogeneización y mantener la paridad de acceso a los derechos. Las políticas de la diferencia y sus relativos derechos diferenciados se adoptan y se persiguen para el específico fin del reconocimiento de múltiples identidades, a las cuales se vinculan necesidades de ciudadanía específicas. La política de los derechos diferenciados es una política del reconocimiento, ya sea en sentido tayloriano, como necesario proceso de construcción de la identidad (Taylor 1992), ya sea como proceso de reconocimiento constitucional y legal. ${ }^{9}$ La idea de reconocimiento se junta, de

8 Aunque esto no soluciona la problemática de múltiples ciudadanías en el interior de una espacio nacional, y cómo esto puede causar una superposición de comunidades políticas tal vez en contraposición la una con la otra y potencialmente conflictivas.

9 Véase también Yashar (2005). 
formas diferentes y complejas, con la idea de ciudadanía en las relaciones entre ciudadanía y movimientos indígenas en América Latina. El reconocimiento de entidades étnico-culturales -en la definición de la identidad y en la afirmación política- para la libre expresión de ciudadanías diferenciadas a menudo en el marco de autonomías político-económicas es probablemente el contenido principal de las demandas, y el punto de partida de una practica ciudadana completa. Lo que vuelve aún más compleja la situación -que nos interesa discutir en la presentación de los estudios de casos- son también los límites de las categorías que delinean las etnicidades. Ellas se presentan siempre más matizadas y compuestas, creando fuertes complicaciones de reconocimiento y, por eso, de acceso a la ciudadanía. Siendo las identidades relacionales y negociadas, es bastante evidente que varios son los casos de híbridos que se encuentran en interespacios, complejos de definir e identificar, y que cada caso tiene sus peculiaridades y necesita de evaluaciones y argumentaciones específicas. También por eso, si algunas de aquellas preguntas que formulamos tiene una respuesta sólo se puede encontrar en el estudio de casos, y no en una determinación abstracta. Con esas premisas es nuestra intención presentar evidencias etnográficas que, acotando México y Perú bajo un acercamiento antropológico, pretenden mostrar algunas de las problemáticas que acabamos de resumir en esta breve introducción. Esto se justifica, por un lado, debido a aquella tradición de comparación entre las dos naciones que ya tiene una cierta historia en las ciencias sociales; por otro lado, nace de aquella idea de identidad nacional, diferente pero vinculada por varias razones, que en Perú y México se ha ido construyendo en torno a un proyecto de 'hombre nuevo', síntesis ideal de diferentes identidades aunque sujeto históricamente construido según precisos proyectos políticos. ${ }^{10}$

\section{ETNICIDAD NEGOCIADA Y CIUDADANÍA ESTRATIFICADA: UN CASO DESDE LOS} Andes de la sierra de Ancash, Perú

Percepciones, representaciones, autorrepresentaciones negociadas forman una red de relaciones cotidianas que se alimentan de un pasado que ha definido categorías y de un presente que, a lo largo de varios caminos, deconstruye y reformula esas categorías que se ponen en acción también en contextos locales. Para entrar en estas realidades queremos mover nuestra lupa hacia lo

10 Aunque en esta ocasión nos limitamos a utilizar ejemplos de estos dos países, es bien evidente que ese proceso, de maneras diferentes pero con algunos rasgos comunes, está presente también en otras naciones de América Latina. 
local para diseñar un cuadro mínimo, porque es desde allí cómo se cimentan los escenarios nacionales e internacionales. La ciudad de Huari, ${ }^{11}$ región Conchucos, departamento de Ancash, Perú, se halla entre las áreas ecológicas denominadas suni y puna. En sus alrededores gravitan varias comunidades rurales donde la propiedad de la tierra es comunitaria y su usufructo se vincula a las reglas definidas en el estatuto de cada comunidad. ${ }^{12}$ En la región Conchucos, las comunidades se diferencian de los pueblos de "propietarios privados" por este manejo comunal de los recursos. En ambos, la base de la economía es una agricultura que se mueve desde la subsistencia hasta situaciones donde el excedente de producción permite un pequeño comercio ocasional en el mercado central de Huari. La agricultura se acompaña de ganadería de ovinos y bovinos que resulta mejor implementada y más rentable en las comunidades campesinas, donde la gestión de los animales y de los pastos es comunal mediante intercambio de trabajo y faenas colectivas. Es muy significativo que esta estructura social, económica y cultural de las áreas rurales no se defina como "comunidad indígena", sino como "comunidad campesina". El proceso de cambio desde el termino "indígena" al termino "campesino" se produjo durante el gobierno del general Juan Velasco Alvarado, que lideró la junta militar que tomó el poder en 1968. En 1969 su gobierno promulgó la reforma agraria para desmantelar los latifundios y distribuir la tierra a los campesinos. El proceso económico se acompañó de un proceso político y cultural de substitución de categorías étnicas por categorías marxistas, sobre la base del modelo propuesto por Mariátegui. ${ }^{13}$ Este periodo histórico tuvo, en Perú, un impacto fuerte, construyendo un abanico de formas, definiciones y autodefiniciones étnico-culturales extremadamente relacionales y variables según la situación contingente, la necesidad y las percepciones individuales.

El 22 de diciembre de 2006, un grupo de maestros y maestras huarinos organizó un encuentro con algunas escuelas rurales en el teatro de Huari

11 En Huari viven aproximadamente 4.800 personas; es la capital de la Provincia homónima y se encuentra en el departamento de Ancash, Perú. En la provincia de Huari viven 70.000 personas, en un rango de altitud que varía entre 2.150 y 6.370 metros. El distrito cuenta con un total de 9.738 habitantes (INEI 2007), de los cuales 4.153 viven en áreas urbanas y 5.156 , en zonas rurales.

12 Para una más amplia disertación sobre la organización política y administrativa de las comunidades de la región Conchucos, véase Venturoli (2011).

13 Aunque hay que recordar que bajo las juntas militares de izquierda de ese periodo se impulsó bastante el estudio de las culturas indígenas del Perú y la publicación de varios estudios y diccionarios. 
para ofrecer a los alumnos la chocolatada de Navidad. Los niños y las niñas de varias comunidades y pueblos que llegaban al teatro de Huari se distinguían por un específica manera de vestirse, llevando sombreros, mantas, ponchos, polleras de tejidos con colores y dibujos específicos del lugar de procedencia. Los parajes de origen de los niños y niñas se encuentran en pisos ecológicos diferentes, algunos en la puna, entre los 4.000 y los 4.800 metros de altitud, donde no crece vegetación alta sino solamente arbustos como el ichu; ${ }^{14}$ otros en la franja definida como suni, entre los 3.500 y los 4.000 metros, un zona muy habitada y explotada a nivel agrícola; otros en el área llamada 'quechua', entre los 2.500 y los 3.500 metros de altitud, valles donde los microclimas permiten el cultivo de productos mas variados, y donde muy a menudo pasan las pocas carreteras que comunican la sierra con la costa peruana. En la sierra, el morar en una zona ecológica o en otra implica diferentes formas económicas de sustentamiento, de organizaciones sociales, y también de vínculos con los centros socioeconómicos. El paisaje también cambia en los diferentes pisos ecológicos, así como muda la mirada de los habitantes hacia sus paisajes.

Como mencionamos antes, durante el día de la chocolatada, los niños de cada escuela, pertenecientes a diferentes comunidades o pueblos eran identificables según la manera de vestirse. Consideremos ahora tres comunidades: Chaupiloma, Coyota y Pomachaca, asentadas en tres áreas ecológicas diferentes; respectivamente, puna, suni y quechua. La niñas de Chaupiloma llevaban todas una manta de colores (bastante oscuros como azul, verde, etc.) en los hombros y pollera roja sobre unos pantalones de lana; los niños lucían ponchos de lana tintados con pigmentos naturales (rojo escuro, marrón, negro...), sin sombrero. Las niñas de Coyota llevaban todas una camiseta blanca y pollera sin pantalones debajo, sino unas medias cortas de color blanco, un sombrero blanco con flores frescas coloradas amarradas y manta de colores claros (rosado, amarillo, violeta) en las manos; los niños no tenían poncho y llevaban todos el sombrero blanco. Los niños y niñas de Pomachaca estaban vestidos, digamos, sin un criterio específico, y se caracterizaban por no llevar ninguna vestimenta considerada 'tradicional': ni sombrero, ni poncho o manta; sus vestidos no tenían ninguna relación con los colores y los tejidos locales. Podría decirse que estaban vestidos a la manera 'occidental'.

La explicación de los maestros sobre la diversidad evidente del estilo de vestimenta de los alumnos en base a su comunidad de origen se relacionaba

14 Stipa ichu, un arbusto que se utiliza como pasto para animales. 
con los pisos ecológicos: quienes provienen de la puna se visten más por el frío y con colores oscuros porque el ambiente natural no presenta colores particulares debido a la escasez de plantas y flores. Quienes llegan de la suni están más acostumbrados a vivir en un paisaje rico, de exuberante vegetación, y por esta razón aman los colores llamativos. Los de Pomachaca viven al lado de la carretera principal que une la región Conchucos con la costa, y están más en contacto con diferentes realidades de varios lugares, pues por Pomachaca pasan todos los carros y los camiones que traen personas y bienes de las industrias costeras, así que los niños se visten al estilo 'moderno' ${ }^{15}$ (Venturoli 2007).

Probablemente estas diferencias tan marcadas y evidentes no son siempre visibles, y no para todas las comunidades o pueblos: aquello era un evento específico en que los niños seguramente habían sido vestidos por las madres de manera especial. Además, la explicación, tan vinculada al medio, debería ser completada y complejizada con otros análisis. Sin embargo, esta anécdota ejemplifica manifiestamente las diferentes identidades que se construyen en la visión de los habitantes de la provincia de Huari. La verticalidad de los pisos ecológico (Murra 1972) define también una jerarquía social, construida a través de categorías étnicas, que se concretiza también en un diferente acceso y acercamiento al concepto de ciudadanía. En Perú, entre la puna y la llanura costera se mueven las definiciones 'étnicas', las divisiones sociales y económicas así como las diferentes 'interpretaciones' del termino ciudadanía. En los Andes, diferentes categorías se vinculan a la altitud de un pueblo: la altitud es directamente proporcional a su lejanía y aislamiento respeto al centro de desarrollo económico y social, municipal o provincial más cercano. La reclusión y el relativo nivel de aislamiento genera -simbólica y realmente- un atraso económico que en el sentido común se vincula muy estrechamente con el hecho de 'ser indio', ${ }^{16}$ lo que en varios casos es también sinónimo de falta de acceso a la ciudadanía.

Los comuneros de las comunidades rurales se autodefinen como "indígenas" o "indios" y así son considerados por los huarinos. Sin embargo, cuando en las comunidades se autodefinen como "indios" o "indígenas" lo hacen subrayando un aspecto positivo del término, evidenciando con eso sus derechos sobre la tierra y defendiendo su cultura tradicional. Con orgullo, en la comunidad de San Bartolomé de Acopalca la diferencia entre "comuneros" y "mestizos" fue explicada en relación al vinculo con la tierra: "indígenas so-

15 Término usado por uno de los maestros presentes (grabación de campo Ricardo Ibarra Asencio 2006).

16 Confrontar con Mayer (1970); Fonseca (1973). 
mos los descendientes de los antepasados originarios de la tierra" (Amancio, Acopalca, 2004). Al contrario, los huarinos utilizan este término en una perspectiva negativa, oponiéndolo a las definiciones de "españoles" o "mestizos", con las cuales se identifican (Venturoli 2011).

Las definiciones de mestizo, indio o indígena son muy variables (véase Fuenzalida 1970; Mayer 1970; Ossio 1980, 1994; De la Cadena 2000) según la situación, el contexto, el genero ${ }^{17}$ y también la necesidad del momento. En la mayoría de los casos, los habitantes de la zona parecen manejar conscientemente estas categorías según las necesidades, aun cuando el vínculo con el territorio y el lugar de procedencia permanece como el criterio principal en función del cual se imponen las definiciones 'étnicas':

Quien ubica un individuo en una de las dos categorías procede por comparación dentro de un ámbito, social y/o geográfico, en función de una perspectiva ascendente o descendente y en referencia a tipos ideales: según el ámbito se amplíe o se restrinja y la perspectiva se desplace hacia arriba o hacia abajo, el mismo individuo deberá ser ubicado en un distinto casillero (Fuenzalida 1970: 64).

Los pastores de la puna, habitantes de pequeños caseríos, se sitúan geográficamente más arriba con respecto a las comunidades y, sobre la base de la percepción común de la zona, a un nivel de 'indianidad' más elevado con respecto a los de las comunidades. Los comuneros ponen en acción el mismo patrón de distinciones 'étnicas' hacia los de la puna que los huarinos hacia los comuneros. El lugar de origen, y de residencia, identifica un diferente grado de indianidad. ${ }^{18}$ Estas categorías se identifican también con diferentes maneras de vivir, de vestir y de comer, todas las cuales construyen personas y cuerpos física y culturalmente diversos (Venturoli 2007; 2011). Al mismo tiempo, estas diferencias establecen diferentes maneras de vivir y pensar el concepto de ciu-

17 En esta área también "las mujeres son mas indias" (La Cadena 1992); además, las que proceden de algunos lugares, de ciertas comunidades, son aún mas indias que otras, y normalmente los son en un sentido negativo, es decir, los que utilizan esta definición lo hacen de manera despectiva.

18 En su análisis de las relaciones entre mestizos e indios, Juan Ossio define el grado de interrelaciones y de contactos externos sobre la base del espacio ocupado: "El espacio es representado tanto desde una perspectiva vertical como desde una perspectiva horizontal. Según la primera perspectiva el espacio es representado como una sucesión de niveles que van desde los más sociales, en la base, hasta los menos sociales, en la cumbre. Bajo esta representación, el valle aparece como el ámbito de la vida social plena, mientras que la puna, como el ámbito de lo asocial" (Ossio J. 1980: 20). 
dadanía, así como diferentes percepciones construidas de acuerdo con las relaciones sociales que se manejan con el propio entorno y con otras realidades.

En los asentamientos rurales, comunidades y pueblos, la idea de ciudadanía, en el sentido de participar y compartir "espacios" comunes, no solamente físicos, sino también administrativo, políticos e ideológicos, está muy relacionada con la identidad étnica. ${ }^{19} \mathrm{La}$ identidad de las comunidades rurales se concreta sobre dos ámbitos precisos: el pasado de la comunidad, tal como se cimienta en la tradición oral y se reproduce en el ciclo ritual, y las relaciones con otras comunidades y la cabecera provincial. El posicionamiento étnico de cada comunidad en el cuadro social de la provincia se define en base a aquellas categorías que delineamos antes y ese posicionamiento dibuja también los confines del acceso a la ciudadanía y su capacidad de relacionarse con otras realidades.

Desde épocas coloniales Huari representa el centro de poder y el escalón más alto en las jerarquías locales, no sólo por razones socioeconómicas y políticas, ${ }^{20}$ sino también por cuestiones que tienen que ver con la historia y la memoria oral del área, ya que ésta define una jerarquía de representaciones y autorrepresentaciones que los comuneros y los ciudadanos de Huari actualizan para relacionarse entre ellos y buscar reconocimiento. Las categorías étnicas sobre las cuales se edifica la sociedad regional influencian las relaciones sociales entre individuos y grupos, lo que, en varios casos, afecta y determina también la percepción del concepto de ciudadanía así como la posibilidad de acceso a ella. Las discriminaciones étnicas se tornan discriminaciones sociales en la práctica ciudadana, y las herramientas y los conocimientos necesarios varían de acuerdo con la pertenencia étnica. Los derechos políticos y la práctica de ciudadanía se ejercen en contextos de desigualdad étnicamente definidos y con profundas matices socioeconómicos, y hace que la acción política reproduzca esa misma desigualdad. En esos contextos, el ejercicio de la ciudadanía se vincula aún más estrechamente con los lazos amigables y de parentesco dentro de una red clientelar y personalista de gestión de las cosas públicas.

Este patrón no ha sido modificado aún significativamente por las leyes de descentralización y de gestión del Presupuesto Participativo ${ }^{21}$ que se están

19 Estamos esquematizando una situación que no es tan definida en la práctica real y que siempre conserva excepciones y diferencias en cada contexto.

20 "El pueblo como capital distrital o provincial sede del gobierno municipal es por definición un locus de poder, un punto de confluencia en el que 'dominados' y dominantes 'hacia arriba' coinciden" (Diez 2007: 130).

21 "Ley marco de Presupuesto Participativo", n 28056. 
implementando en el Perú desde 2003. Esta ley de intervención de la sociedad civil y de las autoridades de las comunidades y centros poblados en las directivas y decisiones de los gobiernos municipales y regionales nace anteriormente a la llegada de los ingentes fondos que, a partir de 2006, empiezan a fluir en Huari (cfr.Venturoli 2011). Sin embargo, el aumento del presupuesto del canon minero es lo que ha provocado una situación de crecimiento de las desigualdades en el ámbito político que mayormente se concretan en la casi total gestión de la Ley de Presupuesto Participativo por parte de la municipalidad provincial (Venturoli 2012). El buen conocimiento de la ley por parte de los comuneros y sus autoridades permitiría a las comunidades decidir sobre el uso de los fondos del canon minero, elegir los proyectos, priorizar las necesidades y gestionar las relaciones con otros poderes. Lo que ocurre en la provincia de Huari es que la municipalidad provincial, donde hasta ahora se guardan las informaciones, las competencias y los conocimientos para la gestión de los fondos del canon minero, no tiene ningún interés en trasmitir estas nociones a las autoridades comunales. En cambio, pretenden evitar la fragmentación -la descentralización- del poder que hasta antes de esta ley era exclusivo del municipio (Venturoli 2012).

Como mencionamos antes, el estatus de comunidad campesina no se otorga a todos los pueblos rurales del Perú, y solamente aquellos asentamientos que han sido reconocidos por la ley ${ }^{22}$ como tales se benefician de una organización económica y política diferente con respecto a los demás. Las comunidades tienen un cierto grado de autonomía interna mediante un estatuto propio, son organizadas por autoridades locales y gestionan la tenencia de la tierra, y otros recursos, de manera colectiva. Sin embargo, estos derechos especiales no parecen proporcionar un mayor grado de acceso a la ciudadanía en la esfera nacional o regional, y no se reflejan en una ciudadanía substantiva. Al contrario, en algunos casos tienen el efecto de localizar la acción ciudadana de los comuneros al único ámbito de la comunidad y a restringirla dentro de los confines étnicos. Las categorías étnicas no definidas, matizadas y vinculadas a las relaciones internas a niveles regionales hacen también que el reconocimiento a nivel nacional de identidades y ciudadanías diferenciadas no se concretice fácilmente en una instancia de autonomía substancial. Esto no permite la construcción de una capacidad real de decisión sobre los recursos en el mo-

22 La Ley de Reglamentación de las Comunidades Campesinas en el Perú ha sido modificada innumerables veces desde los años veinte del siglo Xx, para profundizar, véase Castillo/Diez/Burneo/Urrutia/DelValle 2007. Algunas comunidades, en nuestra provincia hay dos, tienen títulos de propiedad de la tierra que se remontan al siglo XVII. 
mento en que se establecen relaciones fuera de la comunidad. Las numerosas tentativas frustradas de toma de palabra por parte de las comunidades, andinas y amazónicas, sobre los nuevos proyectos de explotación minera en todo el país son hoy otra evidencia primordial de una autonomía registrada por ley que, sin embargo, no se traduce en una capacidad real y substancial de toma de decisiones. Una autonomía que se realiza dentro de la comunidad, pero que no tiene grandes posibilidades de extenderse hacia fuera en el momento en que debe relacionarse con autoridades externas, sean éstas la municipalidad provincial o las multinacionales mineras atrás del gobierno nacional.

\section{CiUdAdAnía SUSTANTIVA Y ETNICIDAD EN MOVIMIENTO: PROCESOS DESDE EL MÉXICO CONTEMPORÁNEO}

Como el caso del Perú, en donde el binomio etnicidad/ciudadanía varia según la relación que se dé entre diferenciaciones identitarias locales y escenarios nacionales y hasta internacionales, la situación que hoy en día encontramos en México es ejemplar, con sus especificidades, de un conjunto de procesos que se realizan también en el resto de la América Latina contemporánea.

En particular, la declinación étnica de la ciudadanía que estamos discutiendo, podemos apreciarla a partir de, por lo menos, dos procesos que en México han llamado la atención en las ultimas cuatro décadas, y que merecen ser tomados en cuenta en un esfuerzo necesario de acercamiento entre la ciudadanía formal-jurídica y la ciudadanía sustantiva y concreta. Ellos son: la búsqueda de autonomía territorial como intento para fortalecer la inclusión ciudadana por parte de los movimientos indígenas y la resiliencia frente a los procesos de 'desindianización' por parte de grupos que, desde el punto de vista identitario, no caben en el espacio entre el modelo asimilatorio del mestizaje estatal y el modelo reivindicativo de la autonomía indígena. ${ }^{23}$

23 Aparte de estos dos, también los movimientos demográficos de los indígenas hacia las megaciudades y, dentro del marco general de la migración transnacional, las migraciones de indígenas al extranjero cuestionan la vieja idea de una relación exclusiva entre identidades étnicas y territorios rurales ancestrales. Además, invitan a considerar la cuestión de la inclusión ciudadana dentro de territorios extranacionales. Para ello se necesitaría de un apartado especial, así que en esta ocasión nos limitamos a hacer referencia a otros autores para su profundización. Véanse, por ejemplo, para la migración indígena en las ciudades, la síntesis de Pérez-Ruiz (2002) y, para la ciudadanía transnacional, Fitzgerald (2006) y Castro Neira (2006). 
Aunque ambos tienen que ver con el acceso de individuos y grupos a una ciudadanía plena en el sentido marshalliano arriba descrito, los dos procesos mencionados reflejan niveles y caminos diferentes de acceso a la ciudadanía, mostrando en sí mismos, cuánto la ciudadanía liberal es ya, de por sí, 'diferenciada', y cómo, en el caso específico de México, la declinación étnico-identitaria de la ciudadanía está estrechamente relacionada con múltiples dinámicas de inclusión y exclusión.

La primera dinámica de inclusión-exclusión que ponemos en tela de juicio está representada por el proceso de búsqueda de la autonomía en algunos de los territorios indígenas de México. El caso más conocido es el de los territorios autónomos de facto surgidos en Chiapas a raíz del levantamiento neozapatista de 1994, en donde el proceso autonómico ha puesto en marcha prácticas reales de autogobierno en la gestión judicial, sanitaria, educativa, económica y política. Como nos recuerda Leyva (2002), la lucha neozapatista en Chiapas es el resultado de un largo y complejo proceso político en donde el paradigma multiculturalista y del reconocimiento, inicialmente predominante en las demandas de los diferentes movimientos indígenas, en el contexto chiapaneco, como a lo largo del país, deja paso, a partir de los años ochenta, a otro paradigma, el de la autonomía entendida como vía para obtener derechos de ciudadanía. Se produce entonces la conexión entre el proyecto autonómico y la idea de una ciudadanía étnica que De la Peña (1995: 129) define a partir de demandas que para los indígenas son de carácter agrarista (el derecho a la recuperación de sus tierras y de su carácter comunal), políticas (el derecho a la autodeterminación de sus modalidades de autoridad y manejo de la justicia, así como el derecho a tener representantes a nivel intercomunal) y culturales (en donde la educación bilingüe asume un papel fundamental). Estas tres demandas se encuentran reunidas en la afirmación del derecho de los pueblos indígenas a decidir sobre los usos de los recursos naturales y de la inversión pública en sus territorios (De la Peña 1995: 130).

El concepto de 'ciudadanía étnica' puede ser tachado de excluyente y asimilado a la idea de una ciudadanía diferencial, y como subraya siempre Leyva, los movimientos indianistas en México a partir de los años ochenta lo han interpretado de esta forma, identificando a los mestizos como la causa histórica de la exclusión que han padecido. El movimiento neozapatista dio un impulso diferente a la autonomía étnica de los movimientos indígenas mexicanos, apuntando a la construcción de redes interétnicas, nacionales e internacionales, de corte fuertemente incluyente. Un aprendizaje que habría que tomar en cuenta al discutir sobre la ciudadanía étnica, considerándola no 
como un concepto fijo, sino mas bien como un paradigma sujeto a cambios y evoluciones, por lo tanto mucho mas apegado a la realidad.

Aunque de corte algo diferente, otro ejemplo del desarrollo de las reivindicaciones étnicas en términos autonómicos está representado por el reconocimiento constitucional de las elecciones por usos y costumbres en las municipalidades del estado de Oaxaca, en el suroeste de la Republica Federal Mexicana. Se trata de un proceso histórico que culmina en 1995, con la reforma de los artículos 16 y 25 de la Constitución Política del Estado de Oaxaca, que reconoce los derechos de los municipios de ese estado de escoger entre el sistema hasta entonces vigente de elecciones de sus representantes dentro de las planillas de los partidos políticos (como funciona en el resto de la República) o según el sistema de usos y costumbres, caracterizado por diferentes modalidades entre las cuales sobresalen: la designación de autoridades por parte de la asamblea del pueblo, el papel del consejo de ancianos, la observancia del sistema comunitario de cargos progresivos. En 1997 una sucesiva reforma excluye del todo la posibilidad de que los partidos políticos acrediten en sus planillas las autoridades designadas por el sistema consuetudinario (Hernández-Díaz 2007: 58). Tenemos aquí una ejemplificación de la realización de facto y de derecho de la autonomía étnica, aunque limitada en su aspecto político-electoral. El hecho de que la ley de autonomía en Oaxaca se produzca casi en coincidencia con el levantamiento neozapatista indica que ella también es un producto de las demandas de mayor participación en la ciudadanía en uno de los territorios más pobres y también de mayor presencia de población indígena de todo el país. En este proceso participan intelectuales indígenas, movimientos obreros, campesinos y estudiantiles, así como sectores de la Iglesia, pero su actuación es cooptada y al final encabezada por el partido en el poder (el Partido Revolucionario Institucional).

Un primer aspecto problemático consiste en el uso que de la autonomía étnica hace el partido político mayoritario en contra de los demás partidos en una fase histórica de progresiva pluralización de la oferta electoral. Los usos y costumbres, y la consecuente expulsión de las contiendas partidistas en las comunidades permiten al PRI mermar el riesgo de perder el control en favor de otras opciones electorales (Hernández Díaz 2007: 51).

Un segundo aspecto conflictual está en la relación entre las diferentes formas del derecho consuetudinario indígena y los derechos a la plena ciudadanía de sujetos inferiorizados al interior de las mismas comunidades: primeramente las mujeres y los disidentes religiosos. De hecho, estos dos sujetos, por razones y situaciones diferentes, viven una condición de ciudadanía 
diferenciada y limitada que se puede explicitar en la negativa a participar en asambleas, la posibilidad de tomar la palabra, así como en la posibilidad de acceder y subir en el escalafón de los cargos que llevan a los puestos de autoridad (Hernández Díaz 2007: 67-76; Sierra 2002: 277-281; Cuturi 2003). Aunque es fundamental tomar en cuenta e interrogarse sobre estos aspectos críticos, hay que reflexionar atentamente en torno a la relación entre 'la ley' y 'la costumbre': en el caso de la autonomía indígena esta relación es de carácter móvil y procesual, tanto que al cambiar la sociedad (y la costumbre) indígena se va modificando la 'ley'. Una procesualidad nos parece que es mucho menos practicada y obvia en el sistema jurídico formal del Estado nacional.

La segunda dinámica que queremos discutir corresponde al proceso, nunca acabado, de inclusión ciudadana a través de la llamada 'desindianización'. Si, bajo la influencia de la teoría del cambio social, este proceso se ha interpretado como un continuum en la evolución social determinada por la modernización (Nutini 1974), según Bonfil Batalla (1994) ello ha constituido la entrada subordinada de muchos campesinos mexicanos en la ideología nacional del mestizaje, aunque conservando en varias de sus manifestaciones culturales rasgos muy similares a las costumbres indígenas. Ambas visiones, aunque teóricamente opuestas, consideran que, desde el punto de vista identitario, tanto el proceso social como el programa político del mestizaje han producido dos consecuencias: por un lado la progresiva identificación de las masas campesinas con el modelo del 'ciudadano nacional' y, por otro, la diferenciación étnica de algunas minorías en los múltiples Méxicos reconocidos por las políticas indigenistas. Si ya hemos comentado algo sobre las dinámicas de autonomía y ciudadanización étnica, lo que queremos ahora poner en tela de juicio es esta lectura dicotómica del proceso, mirando las consecuencias reales que se han dado por el lado de los llamados 'mestizos'. Para ello se necesita considerar muy atentamente a las relaciones histórico-políticas, dentro del proceso de 'desetnicización' de la ciudadanía.

En el México contemporáneo hay algunos casos estudiados etnográficamente que sirven de ejemplo para mostrar cómo el modelo mas afirmado de inclusión ciudadana no-diferenciada ha resultado en realidad en un proceso inconcluso, lleno de contradicciones e insatisfacciones que hoy en día se están evidenciando a través de modalidades no esperadas. En Zacoalco de Torres, Jalisco, según diversos testimonios (Vásquez Parada y Munguía Cárdenas 2002, Zanotelli 2005), la casi totalidad de los habitantes de los barrios antiguamente indígenas, en la década revolucionaria de los años veinte del siglo pasado, rechazaron participar en el proceso de redistribución de las 
tierras de los hacendados. Su negativa provenía del miedo a la amenaza de excomunión ejercida por el párroco local. En paralelo, se celebraban actos religiosos a escondidas en el barrio, por miedo a que las tropas de las Defensas Rurales dirigidas por el cacique local reprimieran a los creyentes. Sobre estos acontecimientos, la interpretación local de la historia cambia radicalmente según quién tome la palabra. Los actuales ejidatarios y sus descendientes (que nunca se definirían a sí mismos como 'indígenas') consideran al cacique un jefe valiente cuya intención era ayudar a los campesinos explotados por los hacendados. Al contrario, quienes actualmente se encuentran sin derechos agrarios, y que viven en el barrio del pueblo identificado por los demás como 'indígena' por sus formas diferenciadas de conducir los rituales religiosos ( $\mathrm{Za}-$ notelli 2005: 63-79), consideran que el cacique local, habiendo tomado en sus manos las riendas del pueblo y la gestión del reparto agrario, quiso favorecer a sus defensores políticos distribuyendo las tierras del pueblo a gente 'de fuera'. Aunque muy esquemáticamente, este ejemplo nos enseña que en un lugar de México en donde no hay actualmente demandas de autonomía indígena ni tampoco reconocimientos oficiales de la multiculturalidad, en realidad, la opción diferenciada al mestizaje, por ejemplo la atribución de los derechos agrarios a algunos y a otros no por sus diferentes culturas religiosas, ha producido consecuencias en la vivencia actual de sus descendientes. Ellos, por ejemplo, se encuentran sin derechos agrarios en un país en donde ser 'campesino' (en su sentido político-institucional) ha representado la principal forma de inclusión en los derechos ciudadanos para la población rural durante todo el periodo posrevolucionario y por lo menos hasta los años ochenta del siglo pasado.

Tomando ejemplos de otros municipios de la región de Texcoco y del estado de Tlaxcala recopilados por Robichaux (2007), podemos observar que aunque esas poblaciones sean mestizas, o mejor, posindias, por tener un pasado colonial de 'repúblicas de indios', hoy en día reproducen varios sistemas de pertenencia comunitaria que implican para sus integrantes derechos y obligaciones comunales que se van a sumar a aquellos individuales otorgados por la nación, conformando dos clases (a veces conflictivas) de ciudadanía, una local y la otra estatal. La ciudadanía local implica el pago de contribuciones para las fiestas patronales, la cooperación en trabajos comunitarios (anteriormente en mano de obra, actualmente en dinero), etc. En caso de faltas, los castigos pueden ser muy concretos, como el corte del servicio del agua, la negación a utilizar la iglesia para la boda, etc., o bien de orden espiritual, como lo es la creencia en el castigo divino (Robichaux 2007: 15-18). Estos ejemplos, así 
como el de Jalisco, permiten afirmar, una vez más, que el proceso de desindianización no tiene consecuencias unívocas tampoco para las poblaciones cobijadas por el homogenizante termino de 'mestizos', y afirma que el estudio de las relaciones materiales y de las prácticas sociales son herramientas al menos igual de útiles que de las definiciones identitarias para entender el proceso de inclusión-exclusión de la ciudadanía.

Para terminar este breve excurso nos referiremos a otro caso de Jalisco en el cual podemos apreciar la reindianización de grupos de ciudadanos que hasta hace poco no eran contemplados desde el foco de la diferenciación étnica. En la ribera de la laguna de Chapala, Bastos (2011: 97) refiere que Mezcala "[...] como muchas otras comunidades en el país, al no contar con [...] rasgos culturales que la 'definan' o caractericen, no ha sido considerada étnicamente diferenciada y no fueron ni son sujetos de las políticas indigenistas del INI o ahora de la CDI". A pesar de la negación de su identidad en los programas nacionales de 'protección', en la época posrevolucionaria los mezcalenses lucharon y obtuvieron que su origen ancestral fuera reconocido a través de la legislación agrarista, utilizando la titularidad de 'comunidad indígena' para que las tierras quedaran en sus manos. En la época actual, poscampesina, la defensa del territorio pasa por la oposición al despojo de las tierras para fines turísticos e inmobiliarios por parte de fuerzas públicas y privadas. Dentro de este contexto, una parte de los antiguos descendientes de los comuneros, junto con la generación de jóvenes afiliados a la idea autonómica del neozapatismo, ven en la autoadscripción como 'indígenas cocas', o sea, en la etnicización de su lucha por la participación ciudadana, un paso hacia la "[...] recreación y adaptación de la lógica comunitaria al contexto global neoliberal multicultural" (Bastos 2011: 103). Neocomunalismo y reindianización constituyen en este caso una de las consecuencias inconformes del inacabado proceso del mestizaje, mostrando una vez más los huecos de un proyecto político que al querer ser hegemónico más que incluyente, termina por producir exclusiones aun dentro de aquellos grupos que habían históricamente optado por él.

\section{REFLEXIONES FINALES}

Regresamos al concepto de igualdad ínsito en la idea de ciudadanía y nos preguntamos si existe la posibilidad de conciliar esa idea con las específicas instancias étnicas de las poblaciones indígenas en América Latina. Si es verdad 
que una ciudadanía participada es capaz de erosionar jerarquías y privilegios, sobre la base de una relación con el Estado asentada en iguales derechos para todos (Holston/Appadurai 1996), también lo es que no todos los individuos pertenecientes a un Estado gozan de una completa ciudadanía y que muchos grupos e individuos quedan fuera de esa idea incluyente, pues la forma de la ciudadanía no siempre corresponde a su sustancia. Al mismo tiempo, la solución étnica de derechos especiales aparece ambigua y poco eficaz, no solamente porque las definiciones y las categorías étnicas son matizadas, opacas y fuertemente relacionales, ${ }^{24}$ sino también porque el riesgo congénito de cualquier derecho especial, identificado para algunas categorías y no para otras, es aumentar las diversidades, las cuales no siempre son los ladrillos de un sano interculturalismo, sino que a menudo fundamentan la discriminación, en todos los ámbitos.

Igualmente problemática -aunque muy interesante e imposible de obviarnos parece la cercanía del concepto de ciudadanía con aquel de la identidad. Una única identidad nacional definida por los derechos y los caracteres de la ciudadanía nacional, en la mayoría de los casos latinoamericanos, anularía los diversos componentes culturales del Estado y se convertiría en asimilación al estilo de las primeras décadas del siglo xx. Sin embargo, el reconocimiento de las diversas identidades debería implicar también un reconocimiento de diferentes ciudadanías substantivas y formales, abarcando diferentes derechos definidos en base a las diversas necesidades e instancias. ${ }^{25}$ Esto nos pone nuevamente frente al problema de las categorías para las definiciones de los subgrupos dentro del Estado nacional, y de la igualdad para todos los individuos. La tendencia a lo local, o sea, a las comunidades diferenciadas y especiales, puede llevar a discriminación, exclusión y segregación, ${ }^{26}$ al mismo tiempo, la tendencia a lo nacional, o incluso a lo sobrenacional, puede llevar a la fruición de los derechos de ciudadanía a pesar de los orígenes (étnicos, nacionales, etc.), es decir, a los más altos niveles de inclusión substancial. ${ }^{27}$ Pero estos dos niveles siguen lógicas bastantes distintas: la local, más cercana a

24 Sobre el concepto de identidad, véanse Hall/Du Gay (1996) y De la Cadena/ Starn (2010).

25 La globalización como impulso a la homogenización pone en crisis la idea de identidad nacional única y definida así como la orientación a la diversificación interna.

26 Véanse a ese respecto el volumen editado por Kimlicka/Norman en 2000, y el numero de Public culture editado por Holston/Appadurai en 1996.

27 Habría que pensar también el concepto de ciudadanía transnacional, que lleva a una inclsión aún más abierta, pero que tiende a no considerar las diferencias. 
potenciales ajustes y negociaciones y, por ello, mucho mas rápida y pragmática en reaccionar frente a cambios y necesidades de los ciudadanos; la lógica del derecho nacional e internacional es, al contrario, mucho mas burocrática y teórica, y por lo tanto menos hábil en considerar las especificidades y dinámicas de los diferentes contextos. Probablemente el único camino, sin caer en contradicción, es alejarse un poco del concepto vinculado y diseñado sobre la idea europea, blanca y masculina de ciudadanía, que procede del siglo xix, y construir un concepto mas abierto a diferentes interpretaciones y realidades socioculturales que no se definen solamente en base a la pertenencia al Estado, sino también mediante otras formas y condiciones. ${ }^{28}$ Es decir, pensar la ciudadanía como algo mudable y permeable, más incluyente y más matizado, con confines menos nítidos y menos prejuiciosos dentro de los cuales pueden coexistir diferentes maneras de vivir la misma. Una ciudadanía que, como mencionamos anteriormente, tienda a la equidad y no a una igualdad homogeneizante. Desde el punto de vista del investigador, hay que volcarse al estudio de la interacción entre sociedades locales que se autoidentifican de forma diferente (quiénes en términos étnicos, quiénes de otra forma), así como dentro de los movimientos sociales habría que profundizar el conocimiento de cuáles son las dinámicas e interrelaciones que se producen en el contacto entre movimientos que se definen étnicos y los que escogen diferentes adscripciones: ambiental, política, estudiantil, etc., porque una posible solución a todos los problemas que la relación entre ciudadanía y etnicidad provoca (en el presente como en el futuro) es la de agarrar la cuestión a partir del terreno en el cual se está construyendo la convivencia entre modelos jurídicos, adscripciones identitarias y relaciones grupo-individuo diferentes. En décadas anteriores las soluciones a la doble tensión (hacia el modelo individual o hacia las demandas colectivas, así como aquella entre universalismo e relativismo) se ha encontrado alternativamente en el proyecto de inclusión a través de la transformación y la aculturación de los indígenas, o, al contrario, según el más reciente modelo del multiculturalismo, a través del reconocimiento individual como miembro de un grupo culturalmente especifico. Ni uno ni otro permiten comprender todos los casos: entonces, quizás sea más sabio dirigir la atención a las prácticas y las dinámicas de conflicto y convivencia de esos dos modelos en sus declinaciones substantivas, tanto entre colectividades diferentes, así como, dentro de un mismo grupo, entre individuos

28 Como la pertenencia cultural a un territorio especifico dentro del Estado nación, afiliaciones parentales, religiosas, culturales etc., o también considerando la nación como una "comunidad de sentimientos" (Weber 1948) diferente del concepto de Estado. 
e instituciones colectivas. Siempre sin olvidar que estas diferencias derivan de un proceso histórico basado sobre el poder económico, político y militar que ha visto el modelo liberal volverse hegemónico respecto a otros sistemas indígenas de gestión. 
DEMOCRACIA PARTICIPATIVA E CIDADANIA NO BRASIL

\author{
Marianne Wiesebron
}

\begin{abstract}
"Meaningful democracy is more than electoral democracy, it is effective participation in policy making". (Patten 2002)
\end{abstract}

A democracia participativa (DP) foi introduzida na América Latina (AL) no período de redemocratização nos países após os regimes militares. Mas se tratava, em geral, de um regresso à política tradicional, considerada pouco aceitável pela população mais educada, urbanizada e tendo possivelmente participado de algum movimento de resistência, social ou outro, durante a ditadura no seu país. A política tradicional perdeu sua legitimidade e isso levou à procura de outros caminhos, um deles sendo a DP. Este artigo pretende estudar a DP, que se desenvolveu de maneira emblemática no Brasil, e em outros países da AL, e ver se essa forma de participação fortaleceu a cidadania nos lugares onde foi introduzida, e de que maneira isso aconteceu. O enfoque será, sobretudo, o Brasil, em particular Porto Alegre (PA) por ter servido de inspiração para essa nova forma de gestão no continente latino-americano e na Europa. Também se estudará a implementação da DP no Rio Grande do Sul (RS, capital PA), porque a implementação estadual, se bem que menos frequente, tem implicações bem diferentes.

Após as ditaduras militares na América do Sul, o retorno às democracias muitas vezes não trouxe toda a mudança e progresso político esperados. Durante as ditaduras, muitas manifestações diferentes se desenvolveram, movimentos de protestos de todo tipo, contra os militares e seus aliados no poder, e 
também uma série de movimentos populares e sociais com objetivos variados. Esses movimentos foram, às vezes, abafados de modo a dar uma chance ao restabelecimento de democracias estáveis. Foi o caso do Chile, por exemplo, onde os setores da Igreja Católica, que tinha desempenhado um papel ativo contra a ditadura, ajudando os movimentos sociais, queriam agora que esses movimentos reduzissem ou até mesmo parassem suas atividades. Os grupos que recebem o apoio de organizações não-governamentais (ONGs) são confrontados com vários problemas. Um deles é tradicional, e existe também em caso de cooperação com a Igreja, ou seja, alguma forma de dependência ou patrocínio (Mainwaring 1986: 79 e seguintes; Spooner 1994). Segundo MacDonald há outros fatores que complicam o trabalho de movimentos sociais e outros que recebem apoio de ONGs: primeiro, trabalhar com essas organizações muitas vezes implica o uso de critérios e objetivos do primeiro mundo: segundo, se uma ONG funciona bem, isso se deve geralmente às suas boas relações com aqueles no poder; se não, os resultados são bem limitados. Mostrou os resultados ambivalentes sobre o funcionamento da ONG (1995: 29-32). Mesmo assim está ganhando cada vez mais espaço, praticamente considerada o representante da sociedade civil, especialmente como elemento interlocutor de governos (Dagnino 2004: 97-102).

Após o retorno à democracia, foram os partidos políticos que tentaram cooptar esses movimentos sociais e outros, o que também afetou negativamente as suas ações (Banck, Doimo 1988: 71-84). Isto não era surpreendente já que os regimes que tomaram o poder após as ditaduras eram "cautiously reformist, slow to eradicate inequality, elite-dominated and manipulative rather than genuinely participatory" (Cammack 1985: 45). Implicava um retorno à política tradicional, que Gino Germani tinha denominado democracia com participação limitada, com nepotismo, amiguismo, e clientelismo (1973). A isso se pode somar a corrupção, o parco envolvimento das camadas mais baixas, pouco contempladas pelos orçamentos. O Brasil certamente não era uma exceção a esta regra.

Como muitos países na $\mathrm{AL}$, o Brasil se transformou muito rapidamente de uma sociedade rural em uma sociedade altamente urbanizada, devido à modernização e à industrialização do país. ${ }^{1}$ Segundo o censo de 2010 do Instituto Brasileiro de Geografia e Estatística, a urbanização no Brasil já ultrapassa os 80\%. A grande maioria da população brasileira mora em centros urbanos, que inclui duas mega-cidades e um bom número de cidades com mais de um

1 Sobre a urbanização na AL ver, por exemplo: Cerrutti/Bertoncello (2003). 
milhão de habitantes. ${ }^{2}$ No entanto, alguns aspectos da cultura política permaneceram inalterados (Koonings 1999: 221-224).

No Brasil, como no resto da AL, a sociedade estava se modificando: a educação melhorava e se tornava mais generalizada, os meios de comunicação desempenhavam um papel crescente, a economia se desenvolvia, mas, a desigualdade não era reduzida, pelo contrário. Isso levou a uma profunda crise de legitimidade da política tradicional, após o retorno ao regime democrático, que resultou em reações bem diferentes no continente latino-americano:

- Aumento do absenteísmo, ou, em caso de voto obrigatório, a anulação da cédula eleitoral;

- Eleição de candidatos fora do sistema político tradicional porque a população não queria mais candidatos tradicionais dos mesmos partidos de sempre. Em outros casos, políticos tradicionais tentaram evitar esse tipo de resultado formando coalizões, impensáveis no passado;

- Tentativa de revolução, acabando assim com a política tradicional através da rebelião ou da atividade guerrilheira. A lista desses grupos é extensa e guerrilhas e rebeliões continuam perturbando o sistema.

- Experimentos com a democracia direta. Nos anos oitenta e noventa diferentes formas de democracia direta (DD) foram desenvolvidas na AL. O Comandante Borge dos Sandinistas na Nicarágua queria ir mais longe: era favorável à eliminação do parlamento como instituição intermediária da representação e ao estabelecimento da consulta direta da população. Formas menos drásticas foram introduzidas no continente (Artigas 2005; Couffignal 2001; Hagopian 1993; Koonings/Kruijt 1999, Lievesley 1999).

Muitos países introduziram uma forma de DP municipal, em alguns lugares, de forma modesta, em outros, de maneira bem elaborada. Isso tem levado a grandes tensões com a política nacional que, sobretudo, nos primeiros anos, continuava tradicional, especialmente em relação à atribuição de meios financeiros. Como Santos explica:

É uma forma de gestão pública que procura romper com a tradição autoritária e patrimonialista das políticas públicas, recorrendo à participação directa da população em diferentes fases da preparação e da implementação

2 A partir dos anos 1950, o Brasil passa a se tornar um país mais urbanizado. Em 1940, a urbanização era somente de $31 \%$. Sobre a mudança da sociedade urbana ver Baiocchi (2003: 1-9). 
orçamental, com uma preocupação especial pela definição de prioridades para a distribuição dos recursos de investimento (2003: 384). Essa nova forma de democracia, apesar de todos os desafios e dificuldades que teve de enfrentar, tem levado a bons resultados junto a populações locais devido à sua participação bastante ativa nesse processo como será analisado mais adiante.

$\mathrm{Na}$ AL, esse projeto evoluiu mais no Brasil, onde essa experiência começou em 1989, em PA. O projeto de DP de PA tornou-se emblemático e tem sido reconhecido como tal por organismos internacionais como o Programa das Nações Unidas para o Desenvolvimento (PNUD) e o Banco Mundial (BM), que o consideram como boa prática e estimulam cidades a adotar esse sistema de gestão (Milani 2008: 571). Também recebeu uma série de prêmios de instituições internacionais, como Habitat, já em 1995, e foi reconhecido como best practice em 1996 na Conferência Habitat II (Porto de Oliveira 2012). Alguns outros municípios onde o Orçamento Participativo (OP) foi estabelecido também receberam prêmios, em particular Belo Horizonte $(\mathrm{BH})$, considerado o município mais importante em relação ao OP ao lado de PA. O OP de Recife também foi premiado, em 2011 na Alemanha, na primeira edição do Prêmio Reinhard Mohn, concedido pela Fundação Bertelsmann,, entre outros motivos, por envolver muitos jovens no processo. BH também foi premiada naquela mesma ocasião (Marquetti/Campos/Pires 2008; Frey 2011).

No quadro mundial, como a urbanização está crescendo, foi estabelecido um programa para a administração urbana com quatro objetivos estratégicos: erradicar a pobreza urbana, melhorar a gestão de cidades, promover o governo local participativo e reforçar a igualdade de gênero. O Programa de gestão urbana para a AL e o Caribe (PGU-ALC), do Habitat, instituição das Nações Unidas, em conjunto com o PNUD, foi criado para enfocar especificamente projetos de desenvolvimento de novas formas de administração local na ALC. Governos locais trocam experiências por meio de um diálogo preestabelecido, dando especial atenção aos quatro objetivos acima definidos.Várias cidades brasileiras participam do programa Habitat especialmente destinado à gestão participativa na ALC, intitulado Estratégia de Desenvolvimento da Cidade, o qual recebe o apoio do BM e do Programa das Nações Unidas para os Assentamentos Humanos (ONU-HABITAT). Os numerosos problemas, consequências da urbanização crescente no mundo, tais como estabelecer uma infra-estrutura suficiente, serviços que funcionam, mas também aqueles como a migração da população, o colapso social, a violência e as violações dos direitos humanos induziram cidades a seguirem este tipo de programas de cooperação. O programa de OP foi introduzido em numerosas capitais da AL, em muitas cidades 
grandes e menores. Cada município desenvolveu um esquema específico local, porém é o modelo de PA que serviu de base. Algumas experiências duraram vários mandatos, outras tiveram menos sucesso (Becker et al. 2001; Castello Starkoff 2004; Goldfrank 2006; Milani 2008; Rodgers 2010; Talpin 2008).

O OP de PA teve um impacto tão forte que também serviu como inspiração para cidades na Europa, e no Canadá por se tratar realmente de políticas inovadoras. Além do mais, não é somente uma questão de inspiração mas também de cooperação entre a $\mathrm{AL}$ e a União Européia (EU), através do programa URB-AL da Comissão Europeia para incentivar a troca de experiências entre as autoridades locais da EU e da AL.Além de autoridades locais e de técnicos também participam associações, ONGs, sindicatos, universidades e empresas. Seu objetivo é estabelecer redes de cooperação descentralizadas entre as autoridades locais de ambas regiões sobre temas e problemas concretos de desenvolvimento urbano local, tais como redução da pobreza, meio ambiente, combate às drogas, participação cidadã, transportes, segurança e planejamento urbano. No Rio de Janeiro em 1999, durante a $2^{a}$ cúpula dos Chefes de Estado e de Governo dos países da EU, da ALC, o novo tema lançado, Financiamento Local e DP, resultou na formação de uma nova rede temática: a rede URB-AL $n^{\circ}$ 9, coordenada pela Prefeitura de PA, em 2000-2001. Em 2006, essa rede contava com 268 sócios em 15 países da AL, incluindo todos os países sulamericanos que têm o maior número de sócios (Brasil, Peru, etc.), México e vários países centro-americanos. Naquele ano, do lado europeu participavam 128 sócios em 9 países, com um grande número de municípios na Itália, na Espanha. PA pode ter servido de inspiração, porém uma análise comparativa da implementação nas várias cidades revela diferenças tremendas, uns tendo um verdadeiro sistema participativo, outros só um consultivo; uns discutindo realmente a parte de investimentos, outros incorporando só um tema, como a educação, ou só um projeto. Mesmo assim, um dos objetivos da URB-AL no 9 é "constituir em caráter permanente uma Rede de Governos Locais e da Sociedade Civil pela DP" (Milani 2008; Talpin 2008). ${ }^{3}$ Durante a premiação de Recife na Alemanha, foi salientado que o Brasil ainda tem a coragem de experimentar o que não acontece na Europa com as suas democracias que já existem há muito tempo (Frey 2011). Essa cooperação interregional é uma maneira de aprender com as experiências alheias e de modificar certos sistemas muito enraizados. As novas experiências de DP parecem realmente ser uma ruptura com algumas longas práticas da política tradicional na AL.A DP

3 Sobre a Rede 9 URB-AL, ver <http://www2.portoalegre.rs.gov.br/urbal9/>. 
começou a ser construída a partir da década de 70 e, sobretudo, de 80 (Sanchez 2002: 57-58). ${ }^{4}$

\section{ANTECEDENTES DA DEMOCRACIA PARTICIPATIVA}

A ideia por trás de uma forma mais direta de democracia, remonta aos tempos da ditadura no Brasil (1964-1985). Já existiam algumas experiências com a administração popular na década de setenta, vinculadas a políticos de oposição e a movimentos sociais, especialmente na área de educação e de saúde (Vasconcelos 2004: 67-83). Houve a experiência em Pelotas (RS) de 1983 a 1987 pelo prefeito Bernardo de Souza, considerada a incubadora do OP em PA (Gugliano et al in Marquetti 2008: 141-159). Entretanto, outros municípios em vários estados também já tiveram alguma forma de programas participativos, ou melhor de consultas dos cidadãos, elaboradas por prefeitos do Movimento Democrático Brasileiro (MDB) na época do regime militar (Brandão/Ferreira 2002; Sánchez 2002: 16).

Os políticos de oposição estavam todos agrupados no único "partido" autorizado, mas nunca muito bem definido, o MDB, que existiu de 1965 até 1979. Os membros só eram vinculados entre si pela sua oposição ao governo, mas as suas ideologias e pontos de vista podiam ser tremendamente divergentes. Porém, como o MDB teve bastante sucesso, o Governo decidiu permitir novamente a formação de partidos, em 1979, para dividir a oposição. O Brasil se tornou novamente uma nação pluripartidária, com todo um espectro da direita à esquerda (Kinzo 1993: 138-154).

Assim, em 1979, o Partido dos Trabalhadores (PT), foi lançado e estabelecido formalmente em 1980. Foi formado, em primeiro lugar, por líderes sindicais, como Luiz Inácio Lula da Silva, que desempenhou um papel de destaque durante o governo militar. Lula era o mais proeminente líder sindical das cidades industriais mais importantes de São Paulo (SP) (Singer 2001: 14-16). Presidente do sindicato dos metalúrgicos de São Bernardo e Diadema, entrou em contato com outros líderes sindicais, como Jacó Bittar, dos trabalhadores do petróleo em Paulínia (SP), e Olívio Dutra, do sindicato dos bancários em PA (RS). Greves ocorreram em 1978-1979 para melhorar os salários e as condições de trabalho. Em 1979, organizarão uma greve em quinze

4 Vasconcez mostra o funcionamento do OP em vários municípios na AL e na UE, UN-Habitat (2009 [2004]). Existem muitos relatórios do Programa de Gestão Urbana Coordenação para AL e Caribe sobre o OP. Ver, por exemplo, os anos 2001, 2003. 
estados, a qual contou com a participação de três milhões de trabalhadores. Embora essas greves tivessem algum sucesso, os líderes sindicais também se deram conta de que trabalhadores precisavam de uma verdadeira organização política (Keck 1992: 64-66; Baiocchi 2003: 1-14). Num primeiro momento, os líderes sindicais decidiram criar um partido que seria exclusivamente para trabalhadores, mas Lula e outros decidiram aceitar assalariados, de maneira geral. Houve contatos com alguns políticos de esquerda do MDB, entre eles Almino Afonso, ex-ministro do trabalho, no governo Goulart (1961-1964), e Fernando Henrique Cardoso (FHC). Afonso já havia salientado em 1976 a necessidade de um novo partido, nacional popular e democrático, com uma visão do socialismo "no horizonte", que teria que ser verdadeiramente democrático e participativo. O povo e a classe trabalhadora deveria formar uma parte integrante do partido para que "pudesse participar da sua liderança e suas decisões". Dessa forma, a política tradicional e a manipulação não seriam mais possíveis. Cardoso queria uma sociedade civil forte contra um estado (autoritário) para melhorar o processo de democratização. Mas simplesmente ver a sociedade civil oposta ao estado deve ser considerado simplificação demais. Afonso, FHC, e muitos outros passaram a formar o Partido do Movimento Democrático Brasileiro. Alguns se juntaram ao PT e foram muito ativo desde o início, como Eduardo Suplicy. Vários movimentos de esquerda clandestinos e partidos comunistas, que sofreram consideravelmente durante o regime militar, decidiram se juntar ao PT (Keck 1992: 47-48, 55, 69-71, 82, 84-85, 91). Desde o início, comunidades eclesiais de base, da Igreja Católica, inspiradas pela teologia da libertação, desempenharam um papel fundamental no PT. O partido estava aberto a todas as associações comunitárias, sociais e populares interessadas em juntar-se a ele: associações de moradores, de bairro, organizações de mulheres, de indígenas, etc. (Keck 1992: 47-48, 91). Grandes intelectuais de esquerda, como o historiador Sérgio Buarque de Holanda, jornalistas e artistas, como Vinicius de Morais e Caetano Veloso, também foram um fator importante no estabelecimento do PT. Lula tornou-se presidente e Dutra vice-presidente do novo partido (Singer 2001: 20-28).

Desde o início, o PT considerou a DP na administração dos assuntos públicos um dos seus principais objetivos. Raul Pont, o terceiro prefeito petista em PA a implementar o OP, explicou que a introdução da DP era uma maneira de dar novamente legitimidade à politica representativa. ${ }^{5} \mathrm{Ou}$ como Olivio Dutra formulou:

5 Entrevista com Raul Pont, PA, 12-7-2002. 
Nesse projeto, o plantio da cidadania não tem redução de sua área plantada. E em breve devemos começar a colher uma das tantas safras, a que nos possibilitará colocar o Estado sob o controle público efetivo, para que ele funcione com transparência e eficiência no interesse da maioria (1998, apud Marques 1999: 5).

Críticos do OP salientam a 'suposta' pouca democracia do sistema, e que a introdução do OP seria uma maneira de chegar a um regime socialista, senão a uma revolução, ou até a um sistema totalitário. Além do mais, como na segunda fase do OP, há delegados eleitos, isso já não representaria mais a DD (Goldfrank 2006: 6; Goldfrank/Schneider 2006: 14; Ramos 2011). Quando a implementação do OP começou no RS, o PT foi comparado a nazistas alemães e a comunistas soviéticos, descrevendo o OP como uma prática totalitária. As críticas menos ferozes mencionavam práticas ilegais (Goldfrank/Schneider 2006: 14).

O PT desempenhou um papel crucial no desenvolvimento da participação popular, embora tivesse a difícil tarefa de funcionar como partido político, dentro de uma estrutura institucional, enquanto, ao mesmo tempo, introduziu o conceito de participação direta, que não era institucional (Sánchez 2002: 19-23). Esta tensão pode explicar em parte porque a DP não foi introduzida em todos os municípios onde o PT chegou ao poder em 1989. Assim, não foi estabelecido em São Paulo em 1989, quando a candidata do PT foi eleita prefeita, mas quando isso ocorreu novamente, de 2001 a 2004, o OP foi introduzido em São Paulo, mesmo se de forma mais limitada. ${ }^{6} \mathrm{O}$ estado de desorganização de alguns movimentos populares dificultou também o estabelecimento do OP em alguns municípios, enquanto em municípios com movimentos ou grupos bem organizados a tarefa foi bem mais fácil.Vereadores representavam outro problema porque não queriam perder parte do poder, mesmo se ao final do processo, fossem os vereadores que tinham que aprovar a peça orçamentária produzida pelos cidadãos da sua cidade, ou os deputados estuduais que tinham que votar o orçamento.

Além do mais, é bem possível que a coalizão ao governo não tenha a maioria na Câmara deVereadores ou na Assembleia Legislativa Esse foi o caso de PA, durante os quatro mandatos petistas e do Rio Grande do Sul, no primeiro mandato estadual petista (Dias 2006). A Assembleia Legislativa no RS tentou proibir a implemantação do $\mathrm{OP}$ estadual em dois processos, mas não foi possível porque na Constituição de 1988, conhecida como a Constituição cidadã, consta no Título I, Dos Princípios Fundamentais, art. $1^{\circ}$ : “Todo o

6 No governo da Marta Suplicy, o OP foi introduzido em São Paulo.Ver Dias (2006) e Campos em Marquetti (2008: 77-112). 
poder emana do povo, que o exerce por meio de representantes eleitos ou diretamente, nos termos desta constituição" (Marques 1999: 166-167). O Brasil é o único país onde a DD está incorporada na Constituição. Em outros países, como a França, há a possibilidade de organizar um referendo, mas deve ser iniciado por deputados ou o presidente. ${ }^{7} \mathrm{Na}$ Suíça o sistema de referendo é o mais desenvolvido, já que cada alteração da Constituição tem que ser submetida a um referendo. Além dos mais, cidadãos têm a possibilidade de pedir um referendo (Capra Vieira 2009:32-42). Entretanto, na cultura política de alguns países, o referendo não foi incorporado no sistema político do país, por ser considerado um elemento que reduz o poder representativo. A DD, de que o $\mathrm{OP}$ é uma forma, vai muito além do referendo.

\section{ORÇAMENTO PARTICIPATIVO}

Essa inovação foi lançada em PA, capital do RS, no programa eleitoral de 1988 pela Frente Popular (FP). A FP era formada por uma coalizão de partidos da esquerda, liderada pelo PT. O prefeito de PA era petista.

O elemento principal da plataforma eleitoral do FP foi a elaboração da participação direta dos cidadãos durante todo o mandato, em vez de somente uma consulta cada quatro anos através de eleições. O OP é um processo complexo e demorado que se desenvolve ao decorrer do ano. $\mathrm{Na}$ primeira reunião do ano, o governo faz uma prestação de contas, baseado em relatório escrito detalhado, sobre os investimentos aprovados no ano anterior, mostrando em que ponto se encontra a implementação de todos os projetos. O governo apresenta também o Plano de Investimentos, os detalhes do orçamento a preparar para o ano seguinte, qual a quantia disponível, os critérios técnicos, legais e regionais. Tudo isso se encontra definido no regimento interno do OP, que é explicado e distribuído na mesma ocasião. ${ }^{8}$

A discussão dos investimentos é feita por região ou por tema. Cada município é dividido em regiões, baseadas nos bairros existentes, vinculando

7 Constitution de la République française (2011), art.11, e art. 11 em itálico, \& p.3.

8 Para uma explicação detalhada do funcionamento do OP ver Genro/Souza (1997: 52-69). Nesse livro os autores mostram a evolução do OP, um pouco improvisado no início, mas que vai sendo cada vez mais polido. Ver também Abers (2000: 65-90). A verba reservada para esses investimentos representa uma média de $15 \%$ do orçamento total. Numa boa gestão pode subir até uns $20 \%$, numa má baixar até uns $5 \%$. Os gastos fixos como salários ou outras obrigações orçamentárias não são contemplados na discussão do OP. 
àqueles que têm um perfil mais ou menos semelhante economicamente $\mathrm{e}$ socialmente. No caso de PA foram 16 até o ciclo OP 2006/2007. A partir daquele ano passaram a ser 17 regiões, a pedido dos cidadãos da $17^{\mathrm{a}}$ região, do centro de PA. ${ }^{9}$ Além do mais, a partir do segundo mandato da FP em PA, foram estabelecidas plenárias temáticas, sobre assuntos que interessam a todo o município como transporte, saúde, educação, desenvolvimento econômico e desenvolvimento urbano. Essa era uma maneira de cooptar a classe média, empresários, lojistas, representantes sindicais, ONGs com enfoques de gênero, meio-ambiente, menos interessados no processo de participação regional. Os temas gerais foram também adotados por outros municípios como $\mathrm{BH}$, mas nem todos os municípios seguiram essa escolha (Singer 2002: 127). O RS também foi dividido em 22 regiões, mas, se, por uma lado, há um orçamento bem maior, por outro lado, há assimetrias entre as regiões, e, bem mais acentuadas, dentro das regiões. As complicações também eram maiores porque o governo estadual tinha que lidar com 475 municípios, dos quais só 26 tinham OP, entre eles PA (Marques 1999: 159-161).

Como mencionado, cada ano se publica um regimento interno com todas as indicações de como o OP funciona no ano em questão. Desde o início, o regulamento, os critérios foram sendo modificados anualmente, aperfeiçoados, melhorados em relação às experiências do ano anterior, para poder levar em conta carências, população, uma pontuação mais sofisticada, como definir as prioridades, os critérios para eleger os delegados, etc. Em certa medida, na busca de objetividade e transparência, mais detalhado se torna o processo, mais complicado também porque o número de critérios aumenta, a pontuação se torna mais sofisticada. Na pontuação, na atribuição dos projetos e da verba há vários aspectos que devem ser levados em conta: regiões com carências recebem mais pontos do que regiões menos carentes. A demografia é outro fator: uma região mais populosa recebe mais pontos do que outra com menos habitantes. Esse fator pode ser equilibrado pela presença de participantes nas reuniões onde se discute as prioridades. Maior o número de participantes, mais pontos são atribuídos. ${ }^{10}$ Enquanto se publica e distribui o regimento

9 Em BH, se trabalha com 9 regionais, e existe a intenção da Prefeitura de estabelecer 40 subregionais para poder atender melhor aos cidadãos, etc.

10 A divisão do RS em 22 regiões, e todos os outros elementos se encontra, por exemplo, no livrinho: OP RS, O Processo em 2001 para elaborar o orçamento estadual de 2002, (5, 15-16). A pontuação está explicada (10), os detalhes das etapas (6-7), e como se executa uma obra (12), etc. Em 2001 teve uns 400.000 participantes no OP estadual,o dobro do ano 1999 que contou com 190.000 participantes. Marques (1999: 162-163). 
interno, e outros fascículos em que constam todos os detalhes, tudo está claramente definido. Problemas ocorrem em municípios menores que não têm verba para produzir esses fascículos (Gret/Sintomer 2005: 26-37).

Visto que existe pontuação que quantifica a presença durante assembeias, a capacidade de mobilizar pessoas para participar em reuniões do OP pode ser muito útil quando se deseja realizar um projeto. Em geral, escolas têm essa habilidade. As reuniões estão abertas a todos os cidadãos que participam, seja de maneira individual ou dentro de uma organização, como associações de moradores, a categoria que se encontra com maior frequência, de escolas, associações ou movimentos dos sem-casa, dos sem-emprego, etc. As organizações participantes são bem diversificadas (Fedozzi 2007: 30-33). A pontuação ocorre no primeiro semestre porque o processo é cíclico e o calendário é dividido em dois semestres, durante o primeiro ocorre o processo deliberativo, em várias rodadas onde todos os cidadãos interessados tomam parte. ${ }^{11}$ Para fortalecer a transparência, todos os participantes são registrados, e também se estão presentes a título individual ou se representam uma associação. ${ }^{12} \mathrm{Na}$ última rodada daquele ciclo, no final do semestre, os participantes elegem delegados entre as pessoas presentes nas reuniões. O número de delegados tem a ver com o número de presentes e com a população. No segundo semestre, em julho, funcionários do Gabinete de Planejamento da Prefeitura explicam aos delegados como se faz um orçamento e quais são os aspectos legislativos que devem ser levados em conta. Depois os delegados têm que escolher os projetos e estabelecer o orçamento para os projetos nas áreas prioritárias que receberam mais votos no primeiro semestre. Na última fase, a Câmara de Vereadores tem que analisar a proposta global e, se tudo funcionar devidamente, aceitá-la, se está elaborada conforme os critérios legislativos a serem respeitados (Genro/ Souza 1997: 52-69; Gret/Sintomer 2005: 37-40). Como a Prefeitura de BH, que celebrou 15 anos de OP em 2008 (1993-2008), explica num grande cartaz: "Há 15 anos, você decide, a Prefeitura faz, BH acontece". Cada município ou estado tem alguma expressão parecida. ${ }^{13}$

O fascículo 2002 OP RS, Orientações para propostas, debates e votações nas assembleias 2002, é ainda mais aperfeiçoado e os temas são explicados detalhadamente (5-13).

11 Por exemplo, no Regimento Interno do OP do Rio Grande do Sul [OP-RS, 2002/2003] constam as várias fases do processo, as datas das diferentes fases,.... [p. 2]

12 Desde o início, esses registros têm vários objetivos: registrar o número de participantes e sua afiliação a uma associação, mas também ter registros para poder mostrar à oposição.

13 Prefeitura de BH (2008); Frase na capa de todos os documentos do Estado, vinculados ao OP: Regimento Interno 2002/2003; Plano de Investimentos e Serviços 2002, etc. 
Cada participante a uma reunião do $\mathrm{OP}$ tem que assinar um registro. Tudo é registrado, reuniões, participantes, e contabilizado. Assim, para dar um exemplo, em Pelotas (RS) para o OP do ano 2001, foram registrados os dados seguintes:

\begin{tabular}{|l|c|c|}
\hline OP Pelotas, RS, 2001 & $\begin{array}{c}\mathbf{N}^{\mathbf{o}} \\
\text { participantes }\end{array}$ & $\mathbf{N}^{\text {o }}$ reuniões \\
\hline Reuniões Preparatórias & 2.412 & 85 \\
\hline $1^{\text {a }}$ Assembleias Regionais & 3.086 & 43 \\
\hline Assembleias Microregionais & 2.791 & 10 \\
\hline $2^{\text {a Assembleias-regionais }}$ & 845 & 10 \\
\hline Fóruns de delegados & 297 & 158 \\
\hline Total & 9.431 & 43 \\
\hline
\end{tabular}

Dados da Prefeitura Municipal de Pelotas fornecidos por Adair Soares, coordenador do $\mathrm{OP}^{14}$

O perfil dos participantes às várias reuniões foi analisado detalhadamente por Fedozzi, que estudou por reunião elementos como sexo, idade, grau de escolaridade, etnia, renda, ocupação, emprego, horas de trabalho, participação, regional ou temática, abrangendo uma década, de 1995 a 2005 para PA.Também se deteve no perfil dos participantes nas rodadas gerais e daqueles que passam a escrever a peça orçamentária e quantos anos a participação continua. Especialmente na $1^{a}$ parte do ciclo, nas assembleias gerais, notou que o OP é realmente um processo inclusivo, com a participação de um grande número de mulheres, a maioria em certos períodos. Essas mulheres são, geralmente solteiras, viúvas ou separadas. Mulheres casadas participam menos, sem ser claro por quê. As

14 Eleitores: 218.969 / População: 323.034 habitantes [dados de 2002]. Pelotas é um município com OP, com um prefeito petista e uma coalizão da Frente Popular, diferente da coalizão de PA. Em 2001, a cidade era dividida em 10 regiões, para 2002, esse número foi reduzido em 9 , sendo só 1 para o centro, em vez de 2 . A prefeitura publica um regimento interno detalhado com todas as regras para 2002, quem são os conselheiros por região, quais foram as prioridades e as demandas aprovadas em 2001 para 2002 por região, quais são os critérios para poder fazer novas demandas, como se elege delegados. Além do mais se publica uma cartilha bem simples para explicar o OP e um folheto que contem alguns elementos essenciais como as regiões e o cronograma com o periódo das reuniões. Também se publica um folheto com as demandas aprovadas e investimento por região. 
mulheres que representam a maioria nas rodadas gerais, têm baixa escolaridade, ganham até 2 salários mínimos e têm um emprego não qualificado.Aumentou a participação de pessoas que se identificam como negros, porém o autor se pergunta se é por ter aumentado a inclusão ou a consciência negra no país, assunto que se discute mais no Brasil. Se nas rodadas gerais, o processo é inclusivo, poucos desses participantes são eleitos como delegados ou conselheiros. $\mathrm{Na} 2^{\mathrm{a}}$ fase do ciclo, predominam homens com maior escolaridade - em média o segundo ciclo completo e até universitários - com renda maior, se bem que em alguns anos a maioria era formada por mulheres. Uma constatação geral do autor é o número reduzido de jovens interessados e, interessante, a não existência de uma preferência partidária declarada (Fedozzi 2007: 15-28). ${ }^{15}$ O autor também estudou quais são as instituições mais envolvidas no OP, e além de se notar diferenças importantes ao decorrer da década, a Associação de Moradores é a entidade através da qual cerca de metade das pessoas participam, chegando a 65,3\% em 2002, após uma queda para 44,8\% em 2000. Nenhum outro grupo, dos doze mencionados, chega a 10\% (Fedozzi 2007: 30-33).

Quanto aos temas que se discutem, dois são prioritários em cada município, educação e saúde. Cada município ou estado define os temas, que dependem do tipo de município, se o município é praticamente ou totalmente urbanizado ou se contém uma parte rural. Entre os temas a serem discutidos se encontra, em geral, além de educação e saúde, habitação social, transporte público, infraestrutura, segurança, esporte e lazer, turismo e cultura. Municípios com zonas rurais podem ter temas como assentamentos, problemas de zoneamento rural, etc. Para o RS, a agricultura é um tema prioritário em 15 das 22 regiões (Marques 1999: 169). As regiões municipais também têm prioridades diferentes, dependendo do seu perfil. Uma região com favela terá como uma das principais prioridades possíveis, levar as pessoas para fora das habitações precárias. Melhorar o transporte público pode ser outro ítem importante. Esses aspectos se desenvolvem a partir das necessidades e com a experiência adquirida ao decorrer dos anos.

Olívio Dutra foi o primeiro prefeito a implementar o OP em PA. Depois de Olívio seguiram mais três prefeitos do PT, e o OP se tornou institucionalizado, de tal forma; que, quando a FP perdeu as eleições em 2004, o prefeito da oposição manteve o OP, mesmo que, desde então, o dinheiro reservado para o OP tenha sido bem reduzido, mal chega a $1 \%$ do orçamento, enquanto na

15 Durante nossa pesquisa a nível estadual em 2002, também notamos a participação de pessoas de vários partidos ou sem afialiação partidária específica. 
gestão da FP, a margem era de 10 a 15\% do orçamento, uma chegou até acima dos 20\% (Souza 2000: 126-127, e nota 4).

Além do mais, nem todo o dinheiro atribuído ao OP na gestão da oposição é gasto (Rennó/Souza 2012: 241-244). Segundo Rennó e Souza isso se traduz da seguinte maneira:

\begin{tabular}{|l|c|c|c|c|}
\hline & $1989-1992$ & $1993-1996$ & $1997-2000$ & $2001-2004$ \\
\hline Demanda & 0 & 2 & 10 & 7 \\
\hline Paralisada & 0 & 5 & 53 & 337 \\
\hline $\begin{array}{l}\text { Em anda- } \\
\text { mento }\end{array}$ & 474 & 642 & 811 & 660 \\
\hline Concluída & & & & \\
\hline
\end{tabular}

FONTES: Os autores, a partir dos planos de investimento do OP de 2001 a 2008 (Prefeitura Municipal de Porto Alegre 2001, 2002, 2003, 2004, 2005, 2006, 2007, 2008; Rennó/ Souza 2012: 243).

Em valor absoluto, porém, no governo pós-petista não se gastou menos em investimentos do que antes, mas os recursos foram usados em obras maiores e menos verba foi reservada para o OP. Assim, a participação caiu e o empoderamento ficou reduzido (Rennó/Souza 2012: 244-248).

Um dos elementos essenciais para que o OP possa funcionar devidamente é a verba disponível para os investimentos. O executivo tem uma grande influência no orçamento disponível para o OP. Primeiro, há grandes diferenças entre a percentagem dos investimentos disponível para o OP. Em PA, 100\% do orçamento para investimentos se discutem no OP, em BH, só 50\% são transferidos para o OP. Enquanto em Recife, a quantia do OP se limitava a 10\% da verba disponível para investimentos, durante uma administração PMDB-PFL, de 1995 a 2000, e passou a mais de 50\% a partir de 2001, com uma nova administração da Frente de Esquerda do Recife, com prefeito petista (Wampler 2008: 90). ${ }^{16}$ A quantia reservada para o OP tem um impacto evidente no interesse pela participação nas discussões do OP (Wampler 2003: 69).

16 O Partido da Frente Liberal (PFL), de 1985, é um dos dois partidos formado a partir da ARENA (1965-1979). João Paulo Lima e Silva foi eleito o primeiro prefeito petista de Recife e reeleito no $1^{\circ}$ turno em 2004, com ampla aceitação em todo Recife, o que é bastante excepcional. 
Fora do Brasil, se verificou o mesmo efeito: mais verba, mais participação e vice-versa, como Goldfrank verificou numa comparação entre PA, Montevidéu e Caracas. Há outros parâmetros importantes nesse caso. Não se trata somente do orçamento reservado a investimentos, mas da verba total que municípios recebem através de transferências do governo ou administração nacional, definidas pela legislação, e da arrecadação de impostos municipais. Tem a ver com a descentralização do governo. Nos anos 90, Caracas tinha ainda um governo muito centralizado que dava pouca margem de manobra à capital venezuelana, tanto quanto aos temas que eram da competência do município, quanto à verba reservada para o mesmo. Enquanto a Constituição do Brasil de 1988 dava justamente uma autonomia maior aos municípios e orçamentos bastante incrementados. Goldfrank faz uma lista das condições necessárias para que a implementação do OP tenha lugar. Além de recursos suficientes, descentralização, a legislação deve autorizar a participação direta, e deve existir a vontade política para a introdução do OP. Wampler salienta o papel fundamental que o prefeito desempenha para uma boa implementação do OP. (Wampler 2008: 88-90). Crucial também é a existência de "capital social", a existência de uma sociedade civil com movimentos sociais de diversos tipos, e uma administração que seja capaz de implementar um tal processo (Goldfrank 2006: 6, 11-14).

Desde a introdução do OP em PA, um bom número de municípios adotaram a DP, tanto capitais de estado, como grandes municípios e uma quantidade de municípios de tamanho médio e pequeno. A população dos municípios que adotaram o OP variavam de 4000 a 10 milhões de habitantes. Entre 1989 e 1996, dos 225 municípios com mais de 100.000 habitantes, uns 27 adotaram o OP, enquanto esse número passou a 90 no período entre 1997 e 2004. Em 2004, se chegou a 103 municípios com mais de 100.000 habitantes com OP, ou seja " $25 \%$ da população brasileira vivia então num município que utilizava o OP como parte de seu processo de formulação de políticas públicas”. Ao mesmo tempo, em 108 municípios desses 225, o OP nunca foi uma opção (Wampler 2008: 74-75). Nesse caso, não havia nenhuma vontade política em relação à introdução do OP.

Entre as capitais que adotaram o OP, pode-se destacar, além de PA, Salvador, Fortaleza, BH, Belém, Recife, São Paulo. Após PA, BH foi o município onde o OP foi o mais elaborado e continua funcionando dentro da mesma coalizão, com 4 prefeitos do PT, desde 1993 até 2012, durante 5 mandatos. ${ }^{17}$.

17 Ao final do ano 2012, haverá eleições municipais e, dependendo dos partidos que vão ganhar, o OP, atualmente em vigor, continuará tal qual, será modificado, ou suspenso nos diversos municípios. Também é possível que seja (re)introduzido em outros municípios. 
Uma peculiaridade de $\mathrm{BH}$ é que aquela cidade passou de um ciclo anual a um ciclo bianual a partir dos anos 1999 / 2000. Em Belém o OP se manteve durante 2 mandatos petistas (1997-2004), em Recife durante 2 petistas no século XXI, após ter sido adotado por uma coalizão PMDB-PFL, que teve uma política bem menos inclusiva, com pouca verba disponível para o OP. No segundo mandato, o prefeito foi eleito com grande maioria no primeiro turno. Porém a oposição já tinha estabelecido o OP antes, só que a parte dos investimentos a ser discutida era mínima, e por consequência, a população estava pouco interessada em participar. Em São Paulo, onde houve prefeitos do PT, mas não em gestões seguidas, o OP também foi introduzido, porém de forma limitada na segunda gestão petista, de Marta Suplicy, se limitando aos temas de saúde e educação. Entretanto nas cidades industriais cercando São Paulo, na grande $\mathrm{ABC}$ que incorpora Santo André, São Bernardo, São Caetano, Diadema, Mauá e Ribeirão Pires, e Rio Grande da Serra, o OP teve larga tradição (Carvalho e Felgueiras 2000). No Rio Grande do Sul, outros municípios, além da capital, adotaram o OP quando uma coalizão liderada pelo PT ganhava as eleições. A consequência é que, quando a oposição ganha as eleições, ou eliminava simplesmente o OP ou mantinha o OP de maneira diluída, mesmo que fosse considerado um instrumento útil para a gestão. Por outro lado, por essa mesma razão, em alguns municípios em vários estados, coalizões de partidos da direita também trabalharam ou trabalham com o OP, e, da mesma maneira, conseguiram se manter em mandatos seguidos, o que não é tão comum na tradição política do país (Sanchez 2002: 40) A lista de municípios brasileiros com OP é bem mais longa, se bem que continue sendo uma minoria. Em 2007, se constitui uma Rede Brasileira de OP, que conta com a participação de quase uma centena de municípios em 2012. ${ }^{18}$

Não só municípios introduziram o OP, mas governos estaduais da esquerda, sobretudo, petistas, e da direita começaram a transferir a experiência municipal a nível estadual a partir de 1999. Os estados envolvidos nesse processo foram: Acre, Amapá, Distrito Federal; Mato Grosso do Sul, Minas Gerais, Rio de Janeiro, Rio Grande do Sul, Rondônia e São Paulo. Alguns realmente implementaram o OP estadual, outros não foram além da discussão, como em São Paulo, num governo do PSDB, outros desenvolveram experiências específicas como projetos de Zoneamento Ecológico no Amapá e no Acre. Na

18 Seria interessante observar se o fato de pertencer a essa Rede nacional ou a uma ou mais redes interncionais aumenta a probabilidade da manutenção do OP mesmo se a oposição ganhar as eleições. Isso deveria ser verificado a partir de 2013, após as eleições municipais de 2012 
Rondônia, uma peculariadade foi a Assembleia Legislativa que votou uma Lei Complementar, estabelecendo o OP estadual, contra a vontade do Governador que tinha vetado a lei (Henman en Marquetti 2008: 161-179; Orsi 2004; Goldfrank, Schneider 2006:1-2). ${ }^{19}$ O fato de pensar o OP a nível estadual já é mostrar que a DP ganha espaço, mesmo com políticos e partidos tradicionais refratários.

Dois elementos parecem fazer parte do OP em suas diversas formas, com um orçamento maior ou menor, com mais ou menos participação: transparência e accountability, e se encontram mencionados em numerosos estudos, como efeitos positivos e importantes. A consequência é menos corrupção, amiguismo e clientelismo, aspectos típicos da política tradicional (Rennó/ Souza 2012; Goldfrank 2006; Baiocchi 2003). O impacto do OP no empoderamento ou empowerment e na construção da cidadania são mais controversos, se bem que participantes do processo sejam bastante empolgados com a existência do OP como se pode notar nos vários depoimentos que seguem.

\section{EFEITOS DO OP SOBRE A CIDADANIA}

Quando em 2008, o OP completava 15 anos em BH, a prefeitura da cidade fez um livrinho para celebrar esse aniversário e

apresentar um panorama do que foi alcançado nesses 15 anos de parceria estreita com os moradores, que são os verdadeiros protagonistas dessa história, que faz de BH uma cidade mais igualitária e inclusiva (Prefeitura de BH 2008: 12).

Alguns depoimentos de participantes do OP naquela cidade parecem confirmar esse parecer, como esse de Aurenir Pereira da Silva, representante da Comissão Regional de Acompanhamento e Fiscalização do OP (Comforça):

O OP mudou a cidade, deu cidadania a quem não tinha e direito de definir prioridades dos investimentos públicos, levando qualidade de vida para as regiões mais pobres... Estou orgulhosa de pertencer a essa história, pois me sinto parte da construção da cidade (Prefeitura de BH 2008: 9).

Uma outra participante do Comforça, Fátima Félix, que já preside há mais de 20 anos a Associação Comunitária e do Movimento dos Sem-Casa do

19 Lei Complementar No318, 19-8-2005, DOE. N No 339, de 25/08/005; 
bairro Vista Alegre, na Regional Oeste, foi uma das pioneiras em 1993 da primeira reunião do $\mathrm{OP}$ :

Foi histórico, porque significou a participação dos moradores pela primeira vez na tomada de decisões do governo. As conquistas do OP garantiram aos moradores um dos seus maiores direitos: a cidadania. Tornei-me uma das primeiras representantes da Comissão de Acompanhamento e Fiscalização da Execução do OP - Comforça (Prefeitura de BH 2008: 19).

Durante a pesquisa que fizemos no Rio Grande sobre o OP estadual em 2002, último ano daquele mandato, recolhemos depoimentos mais ou menos similares.

Moradores de favelas também salientavam que graças ao OP, pela primeira vez, havia uma diálogo com funcionários da Prefeitura, dispostos a ouvir a opinião e levar em conta sugestões dos moradores. Antes, funcionários só passavam para dar instruções, sempre de cima para baixo, na melhor das hipóteses, ou só recebiam visitas de políticos na véspera de eleições, para depois serem esquecidos novamente.

Recolhemos muito material nas entrevistas quantitativas que fizemos sobre o OP estadual, ao decorrer de 2002, muitos comentários foram acrescentados nos formulários que distribuímos aos participantes durante reuniões. Assim, no dia 13 de julho daquele ano, em PA, assistimos ao curso de formação em orçamento público para os delegados: como fazer a peça orçamentaria, quais eram os elementos a levar em conta, em particular, quais eram as leis que tinham que respeitar. No quadro estadual, montar a peça orçamentária é mais complicado do que no municipal. Aproveitamos aquela reunião para conversar e entrevistar um bom número de presentes. Conseguimos umas 57 entrevistas, e na maioria dos casos, os entrevistados acrescentaram um comentário. Os entrevistados anotaram as seguintes observações:

Mauro Mueller, do Vale do Sul, delegado e conselheiro, acrescentou:

Através do OP, cada cidadão tem a mesma influência para conquistar a obra ou serviço que na sua ótica julga importante na comunidade. Sendo assim se aprende a valorizar o recurso que está sendo investido e ao mesmo valoriza e zela muito mais pela preservação dos bens públicos adquiridos ou conquistados, pois afinal de contas foi construído com o imposto que veio do seu suor. ${ }^{20}$

20 Entrevista da autora com Mauro Mueller, funcionário com educação de terceiro grau professional, de um município sem OP; PA, 13-7-2002. 
Gelson Lucas Ferreira, de Venancio Aires, da mesma região Vale do Rio Pardo, conselheiro, registrou:

Com o O.P. no nosso município as verbas do Estado estão chegando com maior frequência e melhor distribuídas, pois quando começou o O.P. tínhamos 2(duas) escolas de $2^{\circ}$ grau, "ensino médio". Hoje temos 5 (cinco) escolas, e projeto para mais uma. Uma estrada que tinha projeto há mais de 40 anos, estamos fazendo através do O.P. Na agricultura também melhorou bastante. ${ }^{21}$

Gilmar Tadeu Maschio, de Caxias do Sul, explica claramente a importância do OP e a diferença com o sistema representativo:

O OP permite que a população conheça a receita e a despesa do estado e do município e incida diretamente na formulação das políticas públicas de investimentos. Deixamos de ser agentes chamados apenas na época das eleições e permanecer nos anos dos eleitos de braços cruzados para agentes do desenvolvimento econômico e social do estado e da cidade. Enfim, abrimos a caixa preta do orçamento público, desmistificando-o. O controle público enseja o fim da corrupção e do clientelismo. ${ }^{22}$

Enquanto Juraci Klein Luviseto, de Passo Fundo, delegada e conselheira, com outro nível escolar, usa uma forma mais simples para se exprimir:

$\mathrm{O} \mathrm{OP}$ é a forma de exercer a cidadania, indo às assembleias reivindicar as prioridades de cada região e município. O OP é ótimo por quê? É a forma de nós exercermos o direito de cidadã e melhor forma de administrar o dinheiro do Estado que também é nosso. ${ }^{23}$

Silvana Teresa Pirolo, de Caxias do Sul, já há três anos conselheira, salienta o aspecto de cidadania como resultado do OP:

Permite que se faça um governo com a população, uma gestão pública pioneira onde o cidadão não é só cidadão na hora do voto e participa dos rumos

21 Entrevista da autora com Gelson Lucas Ferreira, empresário, com educação de primeiro grau completo, de um município sem OP; PA, 13-7-2002.

22 Entrevista da autora com Gilmar Tadeu Maschio, bancário, com diploma universitário, município com 6 anos de OP; PA, 13-7-2002.

23 Entrevista da autora com Juraci Klein Luviseto, aposentada, com educação de segundo grau completo, município sem OP; PA, 13-7-2002. 
do Estado. Constroem-se mais do que obras físicas ou serviços, um cidadão novo, solidário e que constrói a sua própria história. ${ }^{24}$

Entre as muitas categorias diferentes que participam do OP se encontram funcionários da Brigada Militar, que salientavam que antigamente não podiam estar envolvidos em política, e agora estavam participando ativamente no OP.

Joel Xavier Brasil, de Bajé, brigadiano, delegado e conselheiro comentou que "tomar café com governador é inédito" e acrescentou que "Muita gente não tem entendimento da grandeza do OP". ${ }^{25}$ O Governador Olívio Dutra empossou os 209 conselheiros no dia 13 de julho e tomou café com eles, comentando que o "OP era uma fábrica de consciência da cidadania", antes do início do curso. ${ }^{26}$

Numa reunião em Piratini, município de oposição sem $\mathrm{OP}$, no dia 22 de julho de 2002, entre os 23 entrevistados, a grande maioria eram trabalhadores rurais, com educação de primeiro grau completo, e alguns incompletos, poucos com o secundário, um dos comentários que se encontra várias vezes, é a importância de poder "falar em público". Leni Schröder Krüger, delegada, observa: "É que o agricultor nunca conseguiu nada, agora através do OP está conseguindo alguns financiamentos e recursos e o povo teve o poder de falar ao público". ${ }^{27}$

Em Lajeado, no dia 24 de julho, Leonardo Fernandes salienta a importância da "prestação de contas, a possibilidade de se informar com o governo diretamente". ${ }^{28}$

Nas eleições de 2002, a oposição ganhou e o OP estadual não teve continuidade. Com a eleição de Tarso Genro como governador do RS, o PT e sua ampla coalizão introduziu novamente o OP no Estado mas de maneira bem diferente. Em vez de sistema deliberativo, agora parece muito mais um processo consultivo, preparado pelo Gabinete Digital que permite a participação por

24 Entrevista da autora com Silvana Teresa Pirolo, funcionária, com educação de terceiro grau completo, município com OP; PA, 13-7-2002.

25 Entrevista da autora com Joel Xavier Brasil, bombeiro da Brigada Militar, com educação de segundo grau completo, município com OP; PA, 13-7-2002. A Brigada Militar no Rio Grande do Sul corresponde à Polícia Militar nos outros Estados do Brasil.

26 Correio do Povo, 14-7-2002

27 Entrevista da autora com Leni Schröder Krüger, trabalhadora rural, com educação de primeiro grau completo, município sem OP; Piratini, 22-7-2012.

28 Entrevista da autora com Leonardo Fernandes, funcionário, com educação de segundo grau completo, do município de Boqueirão do Leão, sem OP, Lajeado, 24-7-2002. 
todos os meios de comunicação modernos. O cidadão pode escolher entre projetos que já vêm preparados pelo governo estadual. As propostas podem ser votadas eletronicamente ou em lugares específicos. Há pouca discussão, só uma escolha a fazer. Em 2011, 1.2 milhões de pessoas votaram dentro desse processo. Aliás o sistema atual é chamado de Sistema Estadual de Participação Popular e Cidadã, não mais de $\mathrm{OP} \cdot{ }^{29} \mathrm{O}$ papel de sociabilidade e de formação é bem menor nesse sistema. A "função educativa, o processo de aprendizagem político" que está vinculado ao debate, "falar em público", faz falta. Allém do mais “o processo de transformação do poder" e de inclusão é menos evidente (Avritzer/Pereira 2005: 77; Vitale 2006: 751).

Porém, em entrevistas sobre o estabelecimento da DP em outros países, os comentários são bastante parecidos aos depoimentos anteriores, como mostra uma entrevista sobre o sistema de gestão participativo em Quito, capital do Ecuador:

Este tipo de reuniones ha servido mucho para que no haya ese negociado, comercio, o tráfico de influencias, que muchas veces me ha tocado, porque yo vengo como directivo de mi sector más de 12 años, casi 15 años, antes funcionaban los regalitos, las invitaciones, en cambio ahora no, ahora uno viene, habla directamente con el Señor coordinador o las personas que coordinen, y vamos poco a poco, o sea, con conocimiento y directamente se viene a hablar por necesidades.

Antes, por elecciones se daban 'obritas', en cambio ahora se trabaja con proyectos, o sea, que el barrio empieza desde abajo: antes, por ejemplo, pedíamos un empedrado, pero nos servía unos 3 meses, porque hasta eso conseguíamos el alcantarillado, y la situación de la calle se ponía peor. No había planificación, en cambio ahora sí, se hace con planificación (Starkoff 2004: 19). ${ }^{30}$

Ou como resumam Brandão e Ferreira, que analisaram o OP no município de Maringá:

A participação (é) uma maneira democrática e necessária da sociedade organizar-se politicamente, potencializando o exercício dos direitos da cidadania, buscando sempre a solução negociada dos conflitos, através de espaços públicos, onde o direito de participação é assegurado a todos. [...]

Um processo de democratização do poder local, fazendo a comunidade assumir cada vez mais o seu papel de protagonista, ou seja, de cidadão (2006).

29 O funcionamento do sistema atual [Governo estadual RS] com o Governador Tarso Genro: 2011-2014] se encontra em <http://www.participa.rs.gov.br/>.

30 Entrevista de Paula Starkoff com Hugo Zambrano, San José de Monjas, Quito. 
Mas, entre os participantes nem todos compartilham o mesmo entusiamo sobre o OP, porque se deve esperar bastante tempo até que as demandas votadas sejam executadas, ainda mais em nível estadual por ser mais complexo ou pela falta de cooperação de municípios da oposição (Talpin 2008: 151-153).

Mesmo assim, em municípios e estados com OP se nota também maior participação em outras atividades. Mais pais estão envolvidos nas escolas dos seus filhos.

\section{CONSIDERAÇÕES FINAIS}

Para começar, está claro que o OP dá mais legitimidade à política, graças ao diálogo entre cidadãos e políticos. Ademais, cidadãos estão incluídos, pela primeira vez, na construção do futuro do próprio município ou, em alguns casos do estado. Entre esses cidadãos se encontra atores que não participavam da política tradicional, nem eram contemplados no orçamento. Atualmente esses atores participam e, graças ao efeito redistribuitivo, se reduz as carências e a desigualdade.

Outro aspecto positivo é que o OP torna o sistema bem mais transparente, e portanto isso implica bem menos corrupção, isso durante o processo do OP e, depois, na fase do monitoramento, do controle do orçamento e das obras.

Além do mais, o estabelecimento do OP tem um poder redistribuitivo segundo diversos estudos, já que uma parte do orçamento do município é usada para melhorar a situação da população mais carente. Outro fator importante é a oportunidade do debate, do diálogo, da participação, da aprendizagem justamente pela população mais carente. Porém isso só existe quando o OP é deliberativo, e não somente consultivo. Enquanto o OP deliberativo ajuda a construir a cidadania, isso não é o caso com o processo consultivo, onde não há discussão, só a escolha entre projetos já montados.

Assim, o estabelecimento, a continuidade do OP depende sempre da "vontade política", dos partidos políticos, ou políticos no poder, os quais têm uma margem de manobra muito grande para definir se o OP é deliberativo ou consultivo, qual a percentagem do orçamento reservado a investimentos e, outro ponto importante, qual a percentagem destinada ao OP, a realização das obras aprovadas e votadas, etc. Goldfrank 2006: 6). Essa é uma das debilidades do OP, onde a vitória de outro(s) partido(s) pode por fim ao OP em um município ou estado e o empoderamento dos cidadãos fica bem reduzido, especialmente, se o OP só foi implementado durante um mandato. 
O OP é um processo inovador com grande valor para a construção da cidadania tanto municipal quanto estadual, porém há a necessidade de mais empenho político para que a construção da cidadania seja menos aleatória. Mesmo assim, a experiência do OP mostra que vale a pena investir em outras formas de política, diferentes dos sistemas tradicionais ou já longamente estabelecidos, e que são "laboratórios de democracia que formam cidadãos críticos", sobretudo quando se trata do sistema deliberativo (Gret/Sintomer 2005: 129-135).

Como Denise Vitale afirma:

Participatory democracy... is justified on three grounds. The first is the normative argument that democracy will improve as citizenship is reconstructed and political practice enlarged beyond the representative system. The second is that increased participation is directly related to the reduction of social and economic inequalities. In other words, increased participation is conneted to the achievement of a more substantive, rather than formal democracy. The third is that political participation has an educative function, in that it develops the social and political capacities of each individual (2006: 750).

Em outras palavras, muito mais do que boa prática, se trata de um sistema que, quando está bem elaborado, realmente forma cidadãos. 


\section{BIBLIOGRAFÍA GENERAL}

Abers, Rebecca Neaera (2000): Inventing Local Democracy: Grassroots Politics in Brazil. London: Lynne Rienner Publishers.

Adams, Julia/Orloff, Ann Shola/Clemens, Elisabeth (2005): "Social theory, modernity and the three waves of historical sociology", en Adams, Julia/Orloff, Ann Shola/Clemens, Elisabeth (eds.), Remaking Modernity: Politics, History and Sociology. Durham/London, Duke University Press, pp. 1-72.

Adelman, Jeremy (2011): "Ritos de Estado: violencia y soberanía en Hispanomamérica, 1789-1821”, en Irurozqui, Marta/Galante, Miriam (eds.), Sangre de Ley. Justicia y violencia en la institucionalización del Estado en América Latina, siglo XIX. Madrid: Polifemo, pp. 25-64.

Águila, Alicia del (1997): Callejones y mansiones: espacios de opinión pública y redes sociales en la Lima del 900. Lima: Pontificia Universidad Católica del Perú.

Agulhon, Maurice/Lira, Bernardino et al. (1992): Formas de sociabilidad en Chile, 1840-1940. Santiago de Chile: Editorial Vivaria.

Alimonda, Héctor (eds.) (2003): Ecología, política. Naturaleza, sociedad y utopía. Buenos Aires: Clacso.

Alonso, Paula (comp.) (2004): Construcciones impresas. Panfletos, diarios y revistas en la formación de los Estados nacionales en América Latina, 1820-1920, Buenos Aires: Fondo de Cultura Económica.

- (2010): Jardines secretos, legitimaciones públicas. El Partido Autonomista Nacional y la política argentina a fines del siglo XIX. Buenos Aires: EDHASA.

Altamirano, Carlos (2001): Bajo el signo de las masas (1943-1973). Buenos Aires: Ariel. Anderson, Jeanine (2004): "Mundos en transformación: familias, políticas públicas y su intersección”, en Arraigada, Irma/Aranda, Verónica (comps.), Cambio de las familias en el marco de las transformaciones globales: necesidad de políticas públicas eficaces. Santiago de Chile: Comisión Económica para América Latina y el Caribe, División de Desarrollo Social. 
- (2007): Invertir en la familia. Estudio sobre factores preventivos y de vulnerabilidad al trabajo infantil doméstico en familias rurales y urbanas: el caso de Perú. Lima: Oficina Internacional del Trabajo.

Anderson, Jeanine/Minaya, Li/Figueroa, Blanca (2010): Trabajo infantil doméstico. Percepciones de niñas, niños y adolescentes. Lima:Asociación Grupo de Trabajo Redes.

Annino, Antonio (coord.) (1995): Historia de las elecciones en Iberoamérica, siglo XIX. Buenos Aires: Fondo de Cultura Económica.

AnsAldi, Waldo (2007): "La democracia en América Latina, un barco a la deriva, tocado en la línea de flotación y con piratas a estribor. Una explicación de larga duración", en ANSALDi, Waldo (dir.), La democracia en América Latina, un barco a la deriva. Buenos Aires: Fondo de Cultura Económica, pp. 53-121.

Ansaldi, Waldo/Giordano, Verónica (2012): América Latina. La construcción del orden. Buenos Aires: Ariel, tomo I.

Argeri, María (2005): De guerreros a delincuentes. La desarticulación de las jefaturas indígenas y el poder judicial. Norpatagonia, 1880-1930. Madrid: CSIC.

- (2010): "Los caníbales, el centenario y las memorias. Documentos, lenguajes y contextos", en: Rafart, Gabriel (ed.), Historia social y política del delito en la Patagonia. Neuquén: Educo, pp. 367-381.

- (2011): "La desestructuración de los cacicazgos. Política, justicia e institucionalidad. Pampa y Patagonia (1870-1955)”, en Quijada, Mónica (ed.), De los cacicazgos a la ciudadanía. Sistemas políticos en la frontera, Río de la Plata, siglos XVIII-XX. Berlin: Ibero-Amerikanisches Institut, pp. 309-359.

Artigas, Álvaro (2005): Amérique du Sud: les démocraties inachevées. Paris: Armand Colin. Assembléia Legislativa do Estado de Rondônia (2005): "Lei Complementar n 318 da do 19 de agosto", DOE, n 339, de 25/08/005

Avritzer, Leonard/Pereira, Maria de Lourdes Dolabela (2005): "Democracia, participação e instituições híbridas", en Teoria E Sociedade. Belo Horizonte, número especial, mayo, pp. 16-41.

Avritzer, Leonardo/Navarro, Zander (orgs.) (200): A inovação democrática no Brasil :o orçamento participativo. São Paulo: Cortez.

Baiocchi Gianpaolo (ed.) (2003): Radicals in Power: The Workers' Party and Experiments in Urban Democracy in Brazil. London/New York: Zed Books.

BALdwin, Peter (1992): La política de seguridad social. Bases sociales del Estado de Bienestar europeo, 1875-1975. Madrid: Ministerio de Trabajo y Seguridad Social.

Banck, Geert/Doimo, Ana Maria (1988): "Between Utopia and Strategy; a Case of a Brazilian Urban Social Movement”, en Banck, Geert/Koonings, Kees (eds.), Social Change in Contemporary Brazil. Amsterdam: CEDLA, pp. 71-84.

BAndieri, Susana (2005): Historia de la Patagonia. Buenos Aires: Sudamericana.

Barbalet, Jean Marie (1992): Cittadinanza: diritti, conflitto e disuguaglianza sociale, Introduzione e cura di D. Zolo. Torino: Petrini.

Barreneche, Osvaldo (2007): “¿Lega o letrada? Discusiones sobre la participación ciudadana en la justicia de la ciudad de Buenos Aires durante las primeras décadas 
de la independencia y la experiencia republicana", en Palacio, Juan Manuel/CADioti, Magdalena (eds.), Justicia, política y derechos en América Latina. Buenos Aires: Prometeo, pp. 181-202.

Barriera, Darío (coord.) (2010): La justicia y las formas de la autoridad. Organización política y justicias locales en territorios de frontera. El Río de la Plata, Córdoba, Cuyo y Tucumán, siglos XVIII/XIX. Rosario: ISHIR CONICET-Red Columnaria.

Barry, Carolina (2011): “¿Una cruzada de Evita? El peronismo y la Ley de Sufragio Femenino", en Barry, Carolina (comp.), Sufragio Femenino. Prácticas y debates políticos, religiosos y culturales en Argentina y América. Buenos Aires: Eduntref, pp. 113-144.

Bastos, Santiago (2011): "La nueva defensa de Mezcala: un proceso de recomunalización a través de la renovación étnica”, en: Relaciones, invierno, 125, [vol. XXXII], pp. 87-122.

Becker, Joachim/JäGER, Johannes/RazA, Werner G. (2001): Economía política de Montevideo. Desarrollo urbano y políticas locales. Montevideo: CLAES.

BeChIs, Martha (2008): Piezas de etnohistoria del sur sudamericano. Madrid: CSIC.

Belmartino, Susana et al. (1988): Corporación médica y poder en salud, Argentina, 19201945. Rosario: OPS.

— et al. (2005): "Crisis y reproducción de las políticas sociales", en Suriano, Juan (ed.), Dictadura y democracia (1976-2001). Buenos Aires, Sudamericana.

Bello, Álvaro (2004): Etnicidad y ciudadanía en América Latina. La acción colectiva de los pueblos indigenas. Santiago de Chile: CEPAL.

Benavides, Martín/Mena, Magrith/Ponce, Carmen (2011): El Estado de la niñez en el Perú. Lima: INEI/UNICEF.

Bonaudo, Marta (2003): "Revisitando a los ciudadanos de la República Posible (Santa Fe 1853-1890)", en IEHS, 18, pp. 213-232.

- (coord.) (2005a): Los actores entre las palabras y las cosas. Rosario: Prohistoria.

- (2005b): "Hecho jurídico... hecho político. La conflictiva relación entre poder y justicia en la construcción de la República Posible. Santa Fe 1856-1890”, en CARzolio, María Inés/Barriera, Darío (eds.): Cultura, religión y política. Siglos XIV-XIX. Rosario: Prehistoria, pp. 215-240.

Bonfil Batalla, Guillermo (1987): México profundo. Una civilización negada. México: Grijalbo.

Botana, Natalio (1994): El orden conservador. La política argentina entre 1880 y 1916. Buenos Aires: Sudamericana.

Brailovsky, Antonio Elio (1999): Memoria verde. Historia ecológica de la República Argentina. Buenos Aires: Paidós.

Brandẽo, Elias Canuto/Ferreira, Márcia Regina (2006): “A democratização do Poder Executivo do Município de Maringá”, en Porta da Cidadania, Orçamento Participativo, $<$ http://porta-da-cidadania.blogspot.be/2006/11/oramento-participativo.html>.

Brubaker, Rogers (2004): Ethnicity Without Groups. Cambridge: Harvard University Press. 
Buitron, Aymé (2003): Identidad y maternidad. Estereotipos de género, maternidad adolescente y barreras ante la planificación familiar. Lima: Asociación Peruana de Salud Mental para la Mujer.

Burguete Cal y Mayor, Araceli: (2010): “Autonomía: la emergencia de un nuevo paradigma en las luchas por la descolonización en América Latina”, en GonzÁLEz, Miguel/Burguete Cal y Mayor, Araceli/Ortiz-T. Pablo (coords.), La autonomía a debate: autogobierno indígena y Estado plurinacional en América Latina. Quito: FLACSO/IWGIA/CIESAS/UNICH.

Cabral, João C. da Rocha (2004): Código Eleitoral, 1932, Secretaria de Documentação e Informação, edición facsimilar, en <http://www.tse.gov.br/hotSites/CatalogoPubli cacoes/pdf/codigo_eleitoral_1932.pdf>.

Cadena, Marisol de la (2000): Indigenous Mestizos. The politics of Race and Culture in Cuzco, Peru, 1919-1991. Durham/London: Duke University Press.

Cadena, Marisol de la/Orin, Starn (eds.) (2010): Indigenidades contemporáneas: cultura, política y globalización. Lima: Instituto de Estudios Peruanos.

Caimari, Lila (comp.) (2007): La ley de los profanos. Delito, justicia y cultura en Buenos Aires (1870-1940). Buenos Aires: Fondo de Cultura Económica.

Cammack, Paul (1985): "Democratisation: A Review of the Issues", en Bulletin of Latin American Research, 4:2, pp. 39-46.

Campanhole, Adriano/Lobo Campanhole, Hilton (comps.) (1992): “Constituição da República Federadiva do Brasil, 5-10-1988”, en Constituições do Brasil. São Paulo: Ed.Atlas.

Camps, Sibila (2001): "Los pueblos indígenas: ceremonia sagrada en la pampa. La vuelta a su tierra de Mariano Rosas, el cacique de los ranqueles", en Diario Clarín, 24 junio.

Cansanello, Carlos (2003): De súbditos a ciudadanos. Buenos Aires: Imago Mundi.

Capra Vieira, Pedro (2009): Referendo: Mecanismo de Democracia Direta no Espaço Europeu Dissertação. Tesis en Mestrado em História das Relações Internacionais e Cooperação, Universidade do Porto.

Carvalho, José Murilo de (1985): Os bestializados. O Rio de Janeiro e a República que não foi. São Paulo: Companhia das Letras.

- (1995): Desenvolvimiento de la ciudadanía en Brasil. México: Fondo de Cultura Económica.

Carvalho, Maria do Carmo A. A./Felgueira, Débora (2000): Orçamento Participativo no ABC-Mauá, Ribeirão Pires e Santo André. São Paulo: Pólis (Publicações Pólis 34).

Castel, Robert (1997): La metamorfosis de la cuestión social. Buenos Aires: Paidós.

Castello Starkoff, Paula, (2004): También nosotros estamos en capacidad de dar soluciones: la gestión participativa desde sus actores, Cabildo de la Zona Centro del Distrito Metropolitano de Quito-DMQ. Quito: Centro de Investigaciones Ciudad.

Castillo, Pedro/Díez, Alejandro/Burneo, Zulema/Urrutia, Jaime/Valle, Pablo del (eds.) (2007): ¿Que sabemos de las comunidades campesinas? Lima: Centro Peruano de Estudios Sociales. 
Castro Neira, Yerko (2006): "La mayoría invisible. Ciudadanía y crisis en la migración indígena”, en Alteridades, enero-junio, [vol. 16], número 31, pp. 61-72.

Cavagnoud, Robin (2011): Entre la escuela y la supervivencia. Trabajo adolescente y dinámicas familiares en Lima. Lima: Instituto de Estudios Peruanos/IFEA/Fundación Telefónica.

Cerrutti, Marcela/Bertoncello, Rodolfo (2003): Urbanization and Internal Migration Patterns in Latin America. Paper prepared for Conference on African Migration in Comparative Perspective, Johannesburg, South Africa, 4-7, June, <http://pum. princeton.edu/pumconference/papers/1-Cerrutti.pdf>.

Chust, Manuel (2004): “El Rey para el pueblo, la Constitución para la Nación”, en Mínguez, Víctor/Chust, Manuel (eds.), El Imperio sublevado. Madrid: CSIC, pp. 225-254.

Chust, Manuel/Marchena, Juan (eds.) (2007): Las armas de la nación. Independencia $y$ ciudadanía en Hispanoamérica (1750-1850). Madrid/Frankfurt: Iberoamericana/ Vervuert.

Clavero, Bartolomé (1997): Happy Constitution. Madrid:Trotta.

Cocca, Aldo A. (1948): La ley de sufragio femenino. Buenos Aires: El Ateneo.

Constitution de la République Française (1958, mise à jour en nov. 2011), $<$ http://www.assemblee-nationale.fr/connaissance/constitution_11-2011.pdf>.

Cotlear, Daniel (ed.) (2006): Un nuevo contrato social para el Perú. ¿Cómo lograr un país más educado, saludable y solidario? Lima: Banco Mundial.

Couffignal, Geroges (2001): "Crise, transformation, et restructuration des systèmes de partis", en l'Amérique latine, Pouvoirs: revue française d'études constitutionnelles et politiques $\mathrm{n}^{\circ} 98$, pp. 103-115.

Cusirramos, Ricardo (2007): "Búscale sentido a tu vida: jóvenes promoviendo participación”, en Grompone, Romeo (ed.), La participación desplegada en la política y la sociedad. Lima: Red para el Desarrollo de las Ciencias Sociales en el Perú, pp. 231-242.

Cuturi, Flavia (2003): Juan Olivares. Un pescatore scrittore del Messico indigeno, Roma: Meltemi.

Chiaramonte, José Carlos (1997): Ciudades, provincias, estados: Orígenes de la nación argentina (1800-1846). Buenos Aires: Ariel.

Dabène, Olivier (1997): L'Amérique latine au XXe siècle. Paris: Armand Colin.

Dagnino, Evelina (2003): Citizenship in Latin America: An Introduction", en Latin American Perspectives, vol. 30, $\mathrm{n}^{\circ}$ 2, Citizenship in Latin America, pp. 3-17.

- (2004): “¿Sociedade civil, participação e cidadania: de que estamos falando?”, en Mato, Daniel (coord.), Políticas de ciudadanía y sociedad civil en tiempos de globalización. Caracas: FACES/Universidad Central de Venezuela, pp. 95-110.

DelRío, Walter (2005): Memorias de expropiación. Sometimiento e incorporación indígena en la Patagonia 1872-1943. Buenos Aires: Universidad Nacional de Quilmes.

Dias, João Marcus Pires (2006): O Orçamento Participativo na cidade de São Paulo-confrontos e enfrentamentos no circuito do poder, tesis de maestría, PUC SP, <http://www. observatoriodasmetropoles.ufrj.br/dissertacao_joao.pdf $>$. 
Dobson, Andrew (2001): “Ciudadanía ecológica ¿una influencia desestabilizadora?”, en Isegorías, 24, pp. 167-187. [Disponible en <isegoria.revistas.csic.es/index.php/ isegoria/article/download/610/611> (23-08-2013).]

Dogan, Mattei/Pahre, Robert (1993): Las nuevas ciencias sociales. La marginalidad creadora. México: Grijalbo.

Durand, Catalina (2007): “Construyendo ciudadanos: jóvenes líderes y organizaciones de afectados por la violencia interna en Ayacucho", en Grompone, Romeo (ed.): La participación desplegada en la política y la sociedad. Lima: Red para el Desarrollo de las Ciencias Sociales en el Perú, pp. 213-230.

Errázuriz Tagle, Javiera (2005): “Discursos en torno al sufragio femenino en Chile, 1865-1949”, en Historia, II [vol.], 8, pp. 257-286.

Evans, Richard J. (1977): The Feminists: Women's Emancipation Movements in Europe, America and Australia 1840-1920. London: Crom Helm.

FALCón, Ricardo (1996): "La relación Estado-sindicatos en la política laboral del primer gobierno de Yrigoyen", en Estudios Sociales, n 10. Rosario: Universidad Nacional del Litoral, pp. 235-273.

Fedozzi, Luciano (2007): Observando o Orçamento Participativo de Porto Alegre - análise histórica de dados: perfil social e associativo, avaliação e expectativas. Porto Alegre: Tomo Editorial.

Fernandes, Florestan (1973): "Problemas de conceptualización de las clases sociales en América Latina”, en Benítez Zenteno, Raúl (coord.), Las clases sociales en América Latina. México: Siglo XXI Editores, pp. 191-276.

FigueroA, Blanca (1996): Laberinto, Este espacio es nuestro, Lotería de la vida. Lima:Asociación Germinal.

FitzGerald, David (2006): "Rethinking emigrant citizenship", en New York University Law Review, [vol. 81], pp. 90-116.

FonseCA, César (1973): Sistemas económicos andinos. Lima: Biblioteca Andina.

Forment, Carlos (2003): Democracy in Latin America, 1760-1900: Civic Selfhood and Public Life in Mexico and Peru. Chicago/London: University of Chicago Press.

FRADKIn, Raúl (comp.) (2007): El poder y la vara. Estudios sobre la justicia y la construcción del Estado en el Buenos Aires rural. Buenos Aires: Prometeo Libros.

Frey, Luisa (2011): "Modelo de participação popular de Recife é premiado na Alemanha”, en <http://opsuzano.blogspot.be/2011/06/modelo-de-participacaopopular-de.html>.

Frugoni, Emilio (1940): La mujer ante el derecho. Montevideo: Editorial Indo-Americana.

FuenZalida, Fernando (1970): “Poder, raza y etnia en el Perú contemporáneo”, en Fuenzalida, Fernando et al., El indio y el poder. Lima: Moncloa-Campodonico Editores/Instituto de Estudios Peruanos, pp. 15-86 [colección Perú-Problema, vol. 4].

Galante, Mirian/IrurozQui, Marta/Argeri, María (2011): La razón de la fuerza y el fomento del derecho: conflictos jurisdiccionales, ciudadanía y mediación estatal (Tlaxcala, Bolivia, Norpatagonia, siglo XIX). Madrid: CSIC. 
Garquin, Enrique (2000): "Relaciones entre Estado y sindicatos durante los gobiernos radicales, 1916-1930”, en PANETtieri, José (ed.): Argentina:Trabajadores entre dos guerras. Buenos Aires: Eudeba, pp. 87-117.

Gaudio, Ricardo/Pilone, Jorge (1984): "Estado y relaciones laborales en el período previo al surgimiento del peronismo", en Desarrollo Económico, vol. 24, nº 94, IDES, pp. 75-101.

Geler, Lea (2007): “Aquí... se habla de política'. La participación de los afroporteños en las elecciones presidenciales de 1874", en Revista de Indias, LXVII, 240, pp. 459-484.

Genro, Tarso/Souza, Ubiratan de (1997): Orçamento participativo: a experiência de Porto Alegre. São Paulo: Editora Fundação Perseu Abramo, $4^{\mathrm{a}}$ ed. ampliada.

Germani, Gino (1973): Política e sociedade numa época de transição: da sociedade tradicional à sociedade de massas. São Paulo: Mestre Jou.

Giordano, Verónica (2012): Ciudadanas incapaces. La construcción de los derechos civiles de las mujeres en Argentina, Brasil, Chile y Uruguay en el siglo Xx. Buenos Aires: Teseo.

Goldfrank, Benjamin (2006): “Los procesos de 'Presupuesto Participativo' en América Latina: éxito, fracaso y cambio", en Revista de Ciencia Política 26 (2), pp. 3-28.

Goldfrank, Benjamin/Schneider, Aaron (2006): “Competitive Institution Building: The PT and Participatory Budgeting in Rio Grande do Sul", en Latin American Politics \& Society, vol. 48, n 3, pp. 1-31.

González Bernaldo, Pilar (2001): Civilidad y política en los orígenes de la nación argentina. Las sociabilidades en Buenos Aires, 1829-1862. Buenos Aires: Fondo de Cultura Económica.

Gordillo, Gastón (2006): En el Gran Chaco. Antropologías e historias. Buenos Aires: Prometeo.

Graham, Richard (1990): Patronage and Politics in Nineteenth-Century Brazil. Stanford: Stanford University.

Gret, Marion/Sintomer, Yves (2005): The Porto Alegre Experiment. Learning lessons for better Democracy. London/New York: Zed Books.

Guerra, Francois-Xavier (1999):"El soberano y su reino. Reflexiones sobre la génesis del ciudadano en América Latina", en Sabato, Hilda (ed.), Ciudadanía política y formación de las naciones. Perspectivas históricas de América Latina. México: Fondo de Cultura Económica, pp. 33-61.

- (2002): "Voces del pueblo. Redes de comunicación y orígenes de la opinión en el mundo hispánico (1808-1814)”, en Revista de Indias, LXII, 225, pp. 357-384.

Guerra, François-Xavier/Lempériere, Annick et al. (1998): Los espacios públicos en Iberoamérica. Ambigüedades y problemas. Siglos XVIII-XIX. México: Fondo de Cultura Económica.

Gutiérrez, Leandro/Romero, Luis Alberto (1995): Sectores populares, cultura y política. Buenos Aires en la entreguerra. Buenos Aires: Sudamericana. 
Hagopian, Frances (1993): “After Regime Change: Authoritarian Legacies, Political Representation, and the Democratic Future of South America", en World Politics, vol. 45, n 3, pp. 464-500.

Halperin Donghi, Tulio (1972): Revolución y guerra. Formación de una elite dirigente en la Argentina criolla. Buenos Aires: Siglo XXI.

- (1982): Una nación para el desierto argentino. Buenos Aires: CEAL.

- (1999): Vida y muerte de la República verdadera (1910-1930). Buenos Aires: Ariel.

Hall, Stuart/Gay, Paul du (eds.) (1996): Questions of Cultural Identity. Los Angeles/ London/Singapore/Washington D. C: SAGE.

Hart, Roger A. (1993): “La participación de los niños: de una participación simbólica a una participación auténtica", en Ensayos Innocenti, n 4, UNICEF.

Heald, David (1995): La democracia y el orden global. Del Estado moderno al gobierno cosmopolita. Barcelona: Paidós.

Hearst, Alice (2004): "Recognizing the Roots. Children's Identity Rights", en Pufall, Peter B./Unsworth, Richard P. (eds.), Rethinking Childhood. New Brunswick/New Jersey: Rutgers University Press, pp. 244-261.

HÉBrard,Veronique (2002): “¿Patricio o soldado: qué uniforme para el ciudadano? El hombre en armas en la construcción de la nación (Venezuela, primera mitad del siglo XIX)", en Revista de Indias, LXII, 225, pp. 429-462.

Heise, María/Landeo Del Pino, Liliam (1996): Relaciones de género en la Amazonía peruana. Lima: Centro Amazónico de Antropología y Aplicación Práctica.

Hernández Chávez, Alicia (2005): "From res publicae to republic. The evolution of the republicanism in early Mexico”, en Rodríguez, Jaime (ed.), The Divine Charter: Constitutionalism and Liberalism in Nineteenth-Century Mexico. Lanham, Md.: Rowman \& Littlefield Publishers Inc., pp. 35-61.

- (2007): "La Guardia Nacional en la construcción del orden republicano", en Chust, Manuel/Marchena, Juan (eds.), Las armas de la nación. Independencia y ciudadanía en Hispanoamérica (1750-1850). Madrid/Frankfurt: Iberoamericana/ Vervuert, pp. 223-246.

Hernández-Díaz, Jorge (coord.) (2007): Ciudadanías diferenciadas en un estado multicultural. Los usos y costumbres en Oaxaca. México: Siglo XXI/UABJO.

Holder, Cindy/Corntassel, Jeff J. (2002): "Indigenous Peoples and Multicultural Citizenship: Bridging Collective and Individual Rights", en Human Rights Quarterly, [vol. 24], The John Hopkins University Press, pp. 126-151.

Holston, James (2008): Insurgent Citizenship, Disjunction of Democracy and Modernity in Brazil. Princeton: Princeton University Press.

Houston, James/Appadurai, Arjun (1996): “Cities and Citizenship”, en Public Culture, [vol. 8], The University of Chicago, pp. 187-204.

Huber, Ludwig (2002): Consumo, cultura e identidad en el mundo globalizado. Lima: Instituto de Estudios Peruanos.

Instituto Brasileiro de Geografia e Estatística (2011): Censo 2010, <http:// www.metadados.ibge.gov.br/detalhePesquisa.aspx? $\operatorname{cod}=\mathrm{CD}>$. 
Íñigo CARrera, Nicolás (1983): La colonización de Chaco. Buenos Aires: CEAL.

IRUROZQUi, Marta (2000): “A bala, piedra y palo”. La construcción de la ciudadanía política en Bolivia, 1826-1952. Sevilla: Diputación de Sevilla.

- (ed.) (2005): La mirada esquiva. Reflexiones históricas sobre la interacción del Estado y la ciudadanía en los Andes (Bolivia, Ecuador y Perú), siglo XIX. Madrid: CSIC.

- (2006): "Sobre el tributo y otros atributos ciudadanos. Sufragio censitario, fiscalidad y comunidades indias en Bolivia, 1825-1839", en Bicentenario. Revista de Historia de Chile y América, 5, 2, pp. 35-66.

IrurozQui, Marta/GaLANTE, Miriam (eds.) (2011): Sangre de Ley. Justicia y violencia en la institucionalización del Estado en América Latina, siglo XIX. Madrid: Polifemo.

IsuANI, Ernesto A. (1985): Los orígenes conflictivos de la seguridad social argentina. Buenos Aires: CEAL.

Jelin, Elizabeth (2003): “Citizenship and Alterity: Tensions and Dilemmas", en Latin American Perspectives, vol. 30, $\mathrm{n}^{\circ}$ 2, Citizenship in Latin America, pp. 101-117.

Keck, Margaret E. (1992): The Workers' Party and Democratization in Brazil. New Haven:Yale University Press.

KimLickA, Will (2003): "Multicultural states and intercultural citizens”, en Theory and Research in Education. Los Angeles/London/Singapore/Washington D. C: SAGE.

Kimlicka, Will/Norman, Wayne (eds.) (2000): Citizenship in Diverse Societies. New York/Oxford: Oxford University Press.

Kinzo, Maria D’Alva G. (1993): “Consolidation of Democracy: Governability and Political Parties in Brazil”, en Kinzo, Maria D’Alva (ed.), Brazil, the Challenges of the 1990s. London/New York: Institute of Latin American Studies and British Academic Press.

Koonings, Kees (1999): "Shadows of Violence and Political Transition in Brazil: from Military Rule to Democratic Governance”, en Koonings, Kees/Kruijt, Dirk (eds.), Societies of Fear: The Legacy of Civil War, Violence and Terror in Latin America. London/New York: Zed Books, pp. 197-234.

Koonings, Kees/Kruijt, Dirk (eds.), Societies of Fear: The Legacy of Civil War, Violence and Terror in Latin America. London/New York: Zed Books.

Kymlicka, Will (1996): Ciudadanía multicultural. Barcelona: Paidós.

LA Rosa, Liliana (2002): Modelos de atención de salud para adolescentes en el Sector Público. Estudios de diez experiencias en el Perú. Lima: Sociedad Peruana de Adolescencia y Juventud.

Lacoste, Pablo (2008): "Mujer, vitivinicultura y participación política", en Espacio Regional, 1 [vol.], 5 [nº], pp. 49-68.

Larner, Wendy/Walters, William (eds.) (2004): Global Governmentality. London: Routledge.

Lavrín, Asunción (2005): Mujeres, feminismo y cambio social en Argentina, Chile y Uruguay, 1860-1940. Santiago de Chile: Centro de investigaciones Diego Barros Arana.

LetTieri, Alberto (2006): La construcción de la república de la opinión. Buenos Aires frente al interior en la década de 1850. Buenos Aires: Prometeo. 
Levy, Terese Svoboda (1997): “Classifying cultural rights”, en Kymlicka, Will/ShaPIRO, Ian (eds.), Nomos XXXIX: Ethnicity and Group Rights. New York: New York University Press.

Leyva Solano, Xochitl (2002): "Las luchas por la 'ciudadanía étnica' en Chiapas y México”, en Revista d'Etnologia de Catalunya, [vol. 21], pp. 54-71.

Liebel, Manfred/Martínez, Marta (2009): Infancia y Derechos Humanos. Hacia una ciudadanía participante y protagónica. Lima: IFEJANT.

Lievesley, Geraldine (1999): Democracy in Latin America: Mobilization, Power and the Search for a New Politics. Manchester/New York: Manchester University Press.

Liscia, María Silvia di/Bohoslavsky, Ernesto (eds.) (2005): Instituciones y formas de control social en América Latina 1840-1940. Buenos Aires: Prometeo.

LoVuolo, Rubén/Barbeito, Alberto (1998): La nueva oscuridad de la política social. Del Estado populista al neoconservador. Buenos Aires: Miño y Dávila/Ciepp.

Lo, Ming Cheng (2005): "The professions: prodigal daughters of modernity", en Adams, Julia/Orloff, Ann Shola/Clemens, Elisabeth (eds.), Remaking Modernity: Politics, History and Sociology. Durham/London, Duke University Press, pp. 381406.

Lobato, Mirta Zaida (1997): "El Estado en los años treinta y el avance desigual de los derechos y la ciudadanía", en Estudios Sociales, Revista Universitaria Semestral, VII [vol.], 12 [n'], pp. 41-58.

Lvovich, Daniel/Suriano, Juan (2006): Las políticas sociales en perspectiva histórica, Argentina, 1870-1952. Buenos Aires: Prometeo.

MacDonald, Laura, (1995): “A Mixed Blessing. The NGO Boom in Latin America”, en Nacla, Report on the Americas, XXVIII: 5 (marzo-abril), pp. 30-35.

Macías, Flavia (2007): “De 'cívicos' a 'guardias nacionales'. Un análisis del componente militar en el proceso de construcción de la ciudadanía. Tucumán, Argentina, 1840-1860". En: Chust, Manuel/Marchena, Juan (eds.), Las armas de la nación. Independencia y ciudadanía en Hispanoamérica (1750-1850). Madrid/Frankfurt: Iberoamericana/Vervuert, pp. 263-289.

- (2011): "Política, Guardia Nacional y ciudadanos en armas.Tucumán, 1862-1868”, en Entrepasados, XIX, pp. 31-50.

Macías, Flavia/Parolo, María Paula (2010): “Guerra de independencia y reordenamiento social. La militarización en el norte argentino (primera mitad del siglo XIX)", en Iberoamericana, 37, año X, pp. 19-38.

Maier, Bárbara (2010): "Los límites de la democratización del bienestar. El Malón de la Paz y La Masacre de Rincón Bomba”, en II Congreso de Estudios sobre el Peronismo (1943-1975). Buenos Aires: Red de Estudios sobre el Peronismo. Mimeo.

Mainwaring, Scott (1986): The Catholic Church and Politics in Brazil, 1916-1985. Stanford: Stanford University Press.

Malamud, Carlos (coord.) (2000): Legitimidad, representación y alternancia en España y América Latina: Las reformas electorales (1880-1930). México: Fondo de Cultura Económica. 
Mandrini, Raúl (2008): La Argentina aborigen. De los primero pobladores a 1910. Buenos Aires: Siglo XXI.

Mansilla, Lucio V. (1993): Una excursión a los indios ranqueles. Buenos Aires: CEAL.

Marques, J. Luiz (org.) (1999): Rio Grande do Sul: Estado e Cidadania. Porto Alegre: Palmarinca.

Marquetti, Aldamir/Campos, Geraldo Adriano de/Pires, Roberto (orgs.) (2008): Democracia Participativa e Redistribuição: análise de experiências de orçamento participativo. São Paulo: Ed. Xama.

Marshall, Thomas Humprhey (1950): Citizenship and Social Class. Cambridge: Cambridge University Press. [MARshall, Thomas Humphrey (2002): Cittadinanza e classe sociale. Ed. a cura di Sandro Mezzadra. Roma/Bari: GLF Editori-Laterza.]

Mases, Enrique (2010): Estado y cuestión indígena. Buenos Aires: Prometeo.

Mayer, Enrique (1970): "Mestizo e Indio: el contexto social de las relaciones interétnicas”, en Fuenzalida, Fernando et al., El indio y el poder. Lima: MoncloaCampodonico Editores/Instituto de Estudios Peruanos, pp. 88-152 [colección Perú-Problema, vol. 4].

Maza Valenzuela, Erika (1995): "Catolicismo, anticlericalismo y la extensión del sufragio a la mujer en Chile", Estudios Públicos, 58 [nº], pp. 138-195.

- (2000): "Las mujeres chilenas y la ciudadanía electoral: de la exclusión al voto municipal, 1884-1934”, en Malamud, Carlos (coord.), Legitimidad, representación y alternancia en España y América Latina: Las reformas electorales (1880-1930). México: Fondo de Cultura Económica. pp. 162-181.

Mc Evoy, Carmen (1997): La utopía republicana. Ideales y realidades en la formación de la cultura política peruana (1871-1919). Lima: Pontificia Universidad Católica del Perú.

Meglio, Gabriel di (2007): "Milicia y política en la ciudad de Buenos Aires durante la guerra de independencia", en Chust, Manuel/Marchena, Juan (eds.), Las armas de la nación. Independencia y ciudadanía en Hispanoamérica (1750-1850). Madrid/ Frankfurt: Iberoamericana/Vervuert, pp. 137-158.

Mejías, Alda Sonia (2004): "Las revoluciones y el sagrado derecho de insurrección de los pueblos: pactismo y soberanía popular en Centroamérica, 1838-1871”, en EIAL, 15, 2, pp. 11-39.

MÉndez, Cecilia (2005): The plebeian republic. The Huanta Rebellion and the making of the peruvian state. 1820-1850. Durham/London: Duke Universiy Press.

Milani, Carlos R. S. (2008): “O princípio da participação social na gestão de políticas públicas locais: uma análise de experiências latino-americanas e europeias”, en Revista de Administração Pública, Rio de Janeiro 42(3), pp. 551-79.

Mimdes-Inei (2010): Encuesta Nacional de Uso del Tiempo 2010. Lima: Gobierno del Perú, Ministerio de la Mujer y Desarrollo Social/Instituto Nacional de Estadística e Informática.

Mimp (2012): Plan Nacional de Acción por la Infancia y la Adolescencia 2012-2021. Lima: Gobierno del Perú, Ministerio de la Mujer y Poblaciones Vulnerables. 
Molinero, Vanetty (2003): Iniciando la Vida en los Andes. Aproximación a los patrones de crianza de familias andinas en la Cordillera Negra. Lima: Diaconía.

Moricete, Bernabel/Hernandéz, Carmen Rosa/Ramos, Juan (2007): Las medidas cautelares y las sanciones: Ejecución en la Justicia Penal Juvenil. Santo Domingo: Escuela Nacional de la Judicatura.

Mouffe, Chantal (comp) (1992): Dimensions of Radical Democracy, Pluralism, Citizenship, Community. London:Verso.

Navajas, María José/CuCCHI, Laura (2012): “Un actor incómodo: prensa política en Córdoba y Tucumán a fines de la década de 1870. Discursos, prácticas y representaciones”, en Secuencia, 82, pp. 41-71.

Nutini, Hugo (1989): "Conclusions: some considerations on the nature and costitution of mestizo culture and society”, en L'uomo, [vol. II n. s.] [n 2], Università di Roma la Sapienza.

Offe, Claus (1990): Contradicciones en el Estado de Bienestar. Madrid: Alianza.

Oкın, Susan Moller (1989): Justice, Gender, and the Family. New York: Basic Books.

Oliart, Patricia (2005): “Género, sexualidad y adolescencia en la provincia de Quispicanchi”, en Oliart, Patricia/Mujica, Rosa María/García S. J., José María (eds.), Quispicanchi. Género y sexualidad. Lima: Instituto Peruano de Educación en Derechos Humanos y la Paz, pp. 9-45.

Olthoff, Jacobijn (2006): A Dream Denied. Teenage Girls in Migrant Popular Neighbourhoods, Lima, Peru. Amsterdam: Dutch University Press.

Orsi, Fábio Chagas (2004): Orçamento Participativo: uma possibilidade na esfera Estadual?, Monografia apresentada na Universidade Metodista de Piracicaba, <http://pires. pro.br/documentosorcamentoparticipativo_umapossibilidadenaesferaestadual--fa biochagasorsi31884.pdf>.

Ossio Acuña, Juan (1994): Las paradojas del Perú oficial. Lima: Pontificia Universidad Católica del Perú.

Osta Vázquez, María Laura (2008): El Sufragio: una conquista femenina. Montevideo: Observatorio del Sur (OBSUR)/Centro de Documentación, Investigación y Promoción Social.

- (2009): "Construindo conceitos de mulheres: o uso da categoria gênero para os debates da convenção nacional constituinte de 1890-1891", en Congreso Internacional de História, Maringá, Paraná, <http://www.pph.uem.br/cih/anais/trabalhos/ 264.pdf>.

Oviedo, Celia (2007): Estado de la población peruana. Indocumentación y grupos étnicos. Lima: INEI.

Palacio, Juan Manuel/Cadioti, Magdalena (2007): Justicia, política y derechos en América Latina. Buenos Aires: Prometeo.

PAlti, Elías (2010): "República y democracia: la democracia como problema”, en Dos siglos después. Los caminos de la revolución. Rosario: Prohistoria.

Paredes, Susel (2005): Invisibles entre sus árboles. Lima: Centro de la Mujer Peruana Flora Tristán. 
Parolo, María Paula (2008): "Ni súplicas, ni ruegos" las estrategias de subsistencia de los sectores populares en Tucumán en la primera mitad del siglo XIX. Rosario: Prohistoria.

Pateman, Carole (1988): The sexual contract. Cambridge: Politi Press.

Patten, Chris (2002): "Latin America - the European Dimension", en Royal Institute of International Affairs Conference Miami, 2, October, <http://europa.eu/rapid/ pressReleasesAction.do?reference $=$ SPEECH/02/447\&format $=$ HTML\&aged $=0$ \&language $=\mathrm{EN} \&$ guiLanguage $=\mathrm{en}>$.

Paz, Carlos (2007): "Conflictos y redes sociales en el proceso de legitimación del poder indígena. En las fronteras Chaqueño-santafesinas. Segunda mitad del siglo xviII", Andes, 18, pp. 251-274.

Pedrero, Malva Marina/Oyarce, Ana María (2011): Salud de la población joven indígena en América Latina. Un panorama general. Santiago de Chile: Naciones Unidas.

PeÑA, Guillermo de la (2005): "La ciudadanía étnica y la construcción de los indios en el México contemporáneo", en Revista Internacional de Filosofía Política, 6, diciembre, pp. 116-140.

Pérez, Ruiz/Maya, Lorena (2002): "Del comunalismo a las megaciudades: el nuevo rostro de los indígenas urbanos”, en PeÑa, Guillermo de la/Vásquez, León Luis (coords.), La antropología sociocultural en el México del milenio. Búsquedas, encuentros y transiciones. México: INI/Conaculta/Fondo de Cultura Económica, pp. 295-340.

Porto de Oliveira, Osmany (2012): “A dimensão internacional do Orçamento Participativo: uma análise da interação entre elites e instituições no processo de difusão", Preparado para o II Seminário Discente da Pós-Graduação em Ciência Política da USP para apresentação na mesa Novas dimensões de ação coletiva à luz das interações entre atores sociais e instituições participativas: mecanismos, efeitos e difusão, <http://www.fflch.usp.br/dcp/assets/docs/SemDisc2012/12-1_Osmany_de_ Oliveira.pdf $>$.

Prado, Maria Emilia (2005): Memorial das desigualdades. Os impasses da cidadanía no Brasil 1870/1902. Rio de Janeiro: Editoria Revan/Faperj.

Prefeitura de Belo Horizonte, Orçamento Participativo de Belo Horizonte 15 Anos (19932008), <http://www.pbh.gov.br/comunicacao/pdfs/publicacoesop/revista_15 anos_portugues.pdf>.

Programa de Gestão Urbana (2003): “Otimização do uso de espaços vazios para Agricultura Urbana através de planos participativos, planificação e gestão para promover a segurança alimentar e governabilidade participativa municipal”, en Governador Valadares, Brasil, <http://www.agriculturaurbana.org.br/sitio/textos/otimi zando.htm>.

- (2001): "Relatório I Encontro Internacional Orçamento Participativo", en Cuaderno de Trabajo, no 94, Quito, <http://www.logolinkla.org/conteudos/documentos/encuentroPP_port(1).pdf>.

Quijada, Mónica (1997): “Ancestros, ciudadanos, piezas de museo. Francisco P. Moreno y la articulación del indígena en la construcción nacional argentina (siglo XIX)", en Estudios Interdisciplinarios de América Latina y el Caribe, 9, pp. 21-46. 
- (2009): “España, América y el imaginario de la soberanía popular”, en Colom, Francisco (ed.): Modernidad iberoamericana. Cultura, política y cambio social. Madrid/ Frankfurt: Iberoamericana/Vervuert, pp. 229-267.

- (ed.) (2011): De los cacicazgos a la ciudadanía. Sistemas políticos en la frontera, Río de la Plata, siglos XVIII-XX. Berlin: Ibero-Amerikanisches Institut.

Quijada, Mónica/Bernard, Carmen/Schneider, Arnd (2004): Homogeneidad y Nación. Un estudio de caso: Argentina, siglos XIX y XX. Madrid: CSIC.

Rafart, Gabriel (2008): Tiempo de violencia en la Patagonia. Bandidos, policías y jueces 1890-1940. Buenos Aires: Prometeo.

Ramos, Camila Souza (2011): “A democracia que muitos não querem”, en Revista Forum, <http://revistaforum.com.br/blog/2011/09/a_democracia_que_muitos_ nao_querem/>.

Remy, María Isabel (2005): Los múltiples campos de la participación ciudadana en el Perú: un reconocimiento del terreno y algunas reflexiones. Lima: Instituto de Estudios Peruanos.

Renno, Lúcio/Souza, Aílton. (2012): "A metamorfose do orçamento participativo: mudança de governo e seus efeitos em Porto Alegre”, en Revista de Sociologia e Política, vol. 20, n 41, Curitiba, pp. 235-252.

Rico, María Nieves/Delamonico, Enrique y colaboradores (2010): Pobreza infantil en América Latina y el Caribe. Santiago de Chile: Naciones Unidas, CEPAL/Unicef.

RoBichaux, David (2007): “Identidades indefinidas: entre 'indio’y 'mestizo’ en México y América Latina”, en Amérique Latine Histoire et Mémoire. Les Cahiers ALHIM, [vol. 13], <http://alhim.revues.org/index1753.html>.

Rodgers Dennis (2010): “Contingent Democratisation? The Rise and Fall of Participatory Budgeting in Buenos Aires”, en Journal of Latin American Studies, 42, pp. 1-27.

Rodrigues, João Batista Cascudo (1982): A mulher brasileira. Direitos políticos e civis. Rio de Janeiro: Editora Renes [2 $2^{\mathrm{a}}$ ed.; $\left.1^{\mathrm{a}}, 1962\right]$.

Rodríguez, Jaime (2005): Revolución, Independencia y las nuevas naciones de América. Madrid: Mapfre/Tavera.

Rodríguez Villamil, Silvia/Sapriza, Graciela (1984): Mujer, Estado y política en el Uruguay del siglo Xx. Montevideo: Ediciones de la Banda Oriental.

RoIG, Arturo (1969): Los krausistas argentinos. Puebla: Editorial Cajica.

Rojas Mira, Claudia (2011): "Rumbo a La Moneda: historia del movimiento sufragista en Chile, 1913-1952”, en BArry, Carolina (comp.), Sufragio femenino. Prácticas $y$ debates políticos, religiosos y culturales en Argentina y América. Buenos Aires: Eduntref, pp. 391-412.

Rosanvallon, Pierre (1995): La nueva cuestión social. Repensar el Estado providencia. Buenos Aires: Manantial.

- (1998): Le peuple introuvable. Histoire de la représentation démocratique en France. Paris: Gallimard.

Ruffini, Martha (2007): La pervivencia de la República posible en los territorios nacionales. Poder y ciudadanía en Río Negro. Buenos Aires: Universidad Nacional de Quilmes. 
Sabato, Hilda (1999): Ciudadanía política y formación de naciones. Perspectivas históricas de América Latina. México: Fondo de Cultura Económica.

- (2006): "La reacción de América: la construcción de las repúblicas en el siglo XIX”, en Chartier, Roger/Feros, Antonio (comps.), Europa, América y el mundo: tiempos históricos. Madrid: Marcial Pons, pp. 263-280.

- (2008): Buenos Aires en armas. La revolución de 1880. Buenos Aires: Siglo XXI.

Sabato, Hilda/LetTieri,Alberto (comps.) (2003): La política en la Argentina del siglo XIX. Armas, votos y voces. Buenos Aires: Fondo de Cultura Económica.

Sampay, Arturo (1963): La Constitución argentina de 1949. Buenos Aires: El Relevo.

SÁnchez, Félix (2002): Orçamento Participativo, teoria e prática. São Paulo: Editora Cortez.

SAPrIZA, Graciela (1988): Memorias de rebeldía: siete historias de vida. Montevideo: GRECMU/Puntosur.

- (2011): “El voto femenino en Uruguay: 1900-1932”, en BARry, Carolina (comp.), Sufragio femenino. Prácticas y debates políticos, religiosos y culturales en Argentina y América. Buenos Aires: Eduntref, pp. 357-390.

Scott, Joan W. (1996): Only Paradoxes to Offer. French Feminists and the Rights of Man. Cambridge: Harvard University Press.

Sierra, María Teresa (2002): "Derecho indígena: herencias, construcciones y rupturas”, en PeÑA, Guillermo de la/VÁsQEz, León Luis (coords.), La antropología sociocultural en el México del milenio. Búsquedas, encuentros y transiciones. México: INI/ Conaculta/Fondo de Cultura Económica.

Singer, André (2001): O PT. São Paulo: Publifolha.

- (2002): "Desafios com que se defrontam as grandes cidades brasileiras", en SoAres, José Arlindo/Bava, Silvio Caccia (orgs.), Os desafios da gestão municipal democrática. São Paulo: Cortez, pp. 97-142 [2ª ed.; 1ª 1998].

Sintomer, Yves/Herzberg, Carsten/Röcke, Anja (2008): "From Porto Alegre to Europe: Potentials and Limitations of Participatory Budgeting", <http://www. buergerhaushalt-europa.de/documents/From_Porto_Alegre8.pdf>.

Smith, Anthony (1997): La identidad nacional. Madrid:Trama.

Sobrevilla, Natalia (2007): "Ciudadanos armados. Las Guardias Nacionales en la construcción de la nación en el Perú de mediados del siglo XIX”, en Chust, Manuel/Marchena, Juan (eds.), Las armas de la nación. Independencia y ciudadanía en Hispanoamérica (1750-1850). Madrid/Frankfurt: Iberoamericana/Vervuert, pp. 159-183.

Souza, Bernardo de (2002): Todo o poder emana do povo. Pelotas: Educat.

SouzA, Marcelo Lopes de (2000): “Para que serve o Orçamento Participativo?”, en Cadernos IPPUR, año XIV, no 2, pp. 123-142.

Spooner, Mary Helen (1994): Soldiers in a Narrow land. The Pinochet Regime in Chile. Berkeley: California University Press.

Suriano, Juan (2000): La cuestión social en Argentina, 1870-1943. Buenos Aires: La Colmena. 
Svampa, Maristella (2005): La sociedad excluyente. La Argentina bajo el signo del liberalismo. Buenos Aires:Taurus.

Talpin, Julien (2008), "Pour une approche processuelle de l'engagement participatif: les mécanismes de construction de la compétence civique au sein d'institutions de démocratie participative", en Politique et Sociétés, vol. 27, n³, pp. 133-164.

TAnzI, Lisandro (2000): Los derechos de los pueblos indígenas en Argentina. Rosario: Universidad Nacional de Rosario.

TAYlor, Charles (1992): La politica del riconoscimento. Milano: Anabasi. [Ed. en español: El multiculturalismo y la política del reconocimiento. México: Fondo de Cultura Económica, 1993.]

Ternavasio, Marcela/Sabato, Hilda/De Privitellio, Luciano/Persello, Virginia (2011): Historia de las elecciones en la Argentina. Buenos Aires: El Ateneo.

Therborn, Göran (1992): “The Right to Vote and the Four World Routes to/through Modernity", en Torstendahl, Rolf (ed.), State Theory and State History. London, Sage, pp. 62-92.

- (2003): "Entangled Modernities", en European Journal of Social Theory, [vol. 6], [n 3], pp. 393-305.

Thibaud, Clément (2011): “La ley y la sangre. La 'guerra de razas' y la Constitución en la América Bolivariana”, en Irurozqui, Marta/Galante, Miriam (eds.), Sangre de Ley. Justicia y violencia en la institucionalización del Estado en América Latina, siglo XIX. Madrid: Polifemo, pp. 65-96.

Thomson, Guy (1990): "Bulwarks of Patriotic Liberalism: The National Guard, Philharmonic Corps and Patriotic Juntas in Mexico, 1847-88", en Journal of Latin American Studies, 22, 1-2, pp. 31-68.

Tilly, Charles (1993): Coerción, capital y los Estados europeos 990-1990. Buenos Aires: Alianza Editorial.

Tomasevski, Katarina (2003): Education Denied: Costs and Remedies. London: Zed Books Limited.

Torrado, Susana (2003): Historia de la familia en la Argentina Moderna. Buenos Aires: Ediciones de la Flor.

Torre, Juan Carlos/Pastoriza, Elisa (2002): “La democratización del bienestar”, en Torre, Juan Carlos (ed.), Los años peronistas (1943-1955). Buenos Aires: Sudamericana.

Unicef (2006): Derecho a la participación de los niños, niñas y adolescentes. Guía práctica para su aplicación. Santo Domingo: Unicef.

Unsain, Alejandro (1952): Ordenamiento de las leyes obreras argentinas. Buenos Aires: El Ateneo.

Valenzuela, Samuel (1985): Democratización vía reforma: la expansión del sufragio en Chile. Buenos Aires: Ides.

Valobra, Adriana (2008): "Feminismo, sufragismo y mujeres en los partidos políticos en la Argentina de la primera mitad del siglo xx", en Amnis, 8, <http://amnis. revues.org/666>. 
- (2009): “...Del hogar a las urnas... consideraciones sobre la ciudadanía política femenina, 1946-1947”, en e-l@tina. Revista electrónica de estudios latinoamericanos, 7 [vol.], 27 [nº, pp. 45-65, <http://www.iealc.fsoc.uba.ar/hemeroteca/elatina/ elatina27.pdf>.

- (2010): Delhogar a las urnas. Recorridos de la ciudadanía política femenina. Argentina, 1946-1955. Rosario: Prohistoria Ediciones.

VAn Bueren, Geraldine (2011): "Multigenerational Citizenship. The Importance of Recognizing Children as National and International Citizens", en The Annals of the American Academy of Political and Social Science, 633, pp. 30-51.

Van Der Maat, Bruno (2009): "La visión de los niños y jóvenes en conflicto con la ley”, en Liebel, Manfred/Martínez, Marta (eds.), Infancia y Derechos Humanos. Hacia una ciudadanía participante y protagónica. Lima: IFEJANT.

VAsconcelos, Eymard Mourão (2004): "Educação Popular: de uma Prática Alternativa a uma Estratégia de Gestão Participativa das Políticas de Saúde”, PHYSIS. Revista Saúde Coletiva, Rio de Janeiro, 14(1), pp. 67-83.

Vasconcez, Jaime/Cabannes, Yves (coords.), (2009 [2004]): 72 perguntas frequentes sobre Orçamento Participativo. Quito: UN-Habitat, <http://www.cm-lisboa.pt/archive/doc/72_perguntas_sobre_OP.pdf>.

VÁsquez, Enrique/Mendizábal, Enrique (eds.) (2002): ¿Los niños... primero? El gasto público social focalizado en niños y niñas en el Perú 1990-2000. Lima: Centro de Investigación de la Universidad del Pacífico.

Vásquez Parada, Lourdes/Munguía Cárdenas, Federico (2002): Protagonistas y testigos de la Guerra Cristera. Guadalajara, Jal.: Universidad de Guadalajara.

VÁzQuez, Pablo (2007): “Evita y la participación de la mujer”, en Instituto Nacional Eva Perón (FIHEP), <http://www.evitaperon.org/evita_peron_instituto-es.htm>.

Venturoli, Sofia (2007): "Vestirsi sulle Ande, una questione di identità", en Domenici, Davide/Saggioro, Alessandro/Venturoli, Sofia (eds.), America Indigena 1. Abiti Identitari, Quaderni di Simbologia del Vestire. Roma: Edizioni Nuova Cultura.

- (2011): Los hijos de Huari. Historia y etnografía de tres pueblos andinos. Lima: Pontificia Universidad Católica del Perú.

- (2012): “"Este conocimiento nadie nos lo va a quitar, el dinero o cualquier cosa que tienes todo te pueden robar'. Canon minero y cambios sociopolíticos en la provincia de Huari, Ancash, Perú”, en Medio Ambiente y Urbanización, [vol. 76], [n 1], abril, pp. 69-90.

Vitale, Denise (2006): "Between deliberative and participatory democracy: A contribution on Habermas", en Philosophy E social criticism, vol. 32, nº 6, pp. 739-766.

WAMPler, Brian (2003): "Orçamento participativo: uma explicação para as amplas variações nos resultados”, en Avritzer, Leonardo/Navarro, Zander (orgs.), A inovação democrática no Brasil: o orçamento participativo. São Paulo: Cortez.

- (2008): “A difusão do orçamento participativo brasileiro: 'boas práticas' devem ser promovidas? Opinião Pública”, en Campinas, vol. 14, n 1, pp. 65-95, <http:// redalyc.uaemex.mx/pdf/329/32914103.pdf>. 
Woodhouse, Barbara Bennett (2004): "Re-Visioning Rights for Children”, en PUfall, Peter/Unsworth, Richard (eds.), Rethinking Childhood. New Brunswick/ New Jersey: Rutgers University Press, pp. 229-243.

Yashar, Deborah (2005): Contesting Citizenship in Latin America. Cambridge/New York: Cambridge University Press.

Zanotelli, Francesco (2001): "La identidad del dinero. Rituales económicos en un pueblo 'mestizo' de Jalisco”, en Relaciones, [vol. XXVI], [n 103], verano, pp. 52-91. Zimmermann, Eduardo (1995): Los liberales reformistas. La cuestión social en la Argentina. Buenos Aires: Sudamericana/Universidad de San Andrés. 
SOBRE LOS AUTORES Y LAS AUTORAS

Jeanine Anderson. M. A. en Antropología, Universidad de Cornell, EE UU. Ph. D. en Antropología, Universidad de Cornell, EE UU, es profesora principal de Antropología y Estudios de género de la Pontificia Universidad Católica del Perú y responsable del curso de Antropología de la salud. Áreas de investigación: organización social de los cuidados, mujeres peruanas en la migración internacional, relaciones intergeneracionales, interculturalidad y salud, estudios cualitativos longitudinales. Ha publicado numerosos artículos en revistas nacionales e internacionales; entre sus ultimas publicaciones se cuentan: Genders and Generations in Shanty Community Development, Lima, Perú, Utopías reales de desarrollo humano: el régimen social peruano a la luz del HDCA, Invertir en la familia : estudio sobre factores preventivos y de vulnerabilidad al trabajo infantil doméstico en familias rurales y urbanas de Colombia, Paraguay y Perú, Cuidado y derechos de las trabajadoras del hogar.

María E. Argeri. Docente de grado y posgrado e investigadora en el Departamento de Política y Gestión de la Facultad de Ciencias Humanas de la Universidad Nacional del Centro de la Provincia de Buenos Aires. Doctora en Filosofia y Letras (Historia-Geografia), sobresaliente cum laude (2004), por la UAM. Desde 2002 es directora del Programa de Estudios Políticos en la UNCPB. Su libro (2005) De guerreros a delincuentes. La desarticulación de las jefaturas indígenas y el poder judicial. Norpatagonia 1880-1930, sintetiza sus investigaciones sobre la historia norpatagónica. Los últimos libros en que ha participado como coautora son: La razón de la fuerza y el fomento del derecho. Conflictos jurisdiccionales, ciudadanía y mediación estatal (Tlaxcala, Bolivia, Norpatagonia, siglo XIX) (2011), en colaboración con Mirian Galate y Marta Iruroz- 
qui. También es autora de "La desestructuración de los cacicazgos. Política, justicia e institucionalidad. Pampa y Patagonia (1870-1955)", IV Parte de De los cacicazgos a la ciudadanía. Sistemas políticos en la frontera, Río de la Plata, siglos XVIII-XX (2011).

Verónica Giordano. Licenciada en Sociología, magíster en Investigación en Ciencias Sociales y doctora en Ciencias Sociales por la Universidad de Buenos Aires (UBA). Es investigadora del Consejo Nacional de Investigaciones Científicas y Técnicas (CONICET), con sede en el Instituto de Estudios de América Latina y el Caribe (IEALC) de la Facultad de Ciencias Sociales de la UBA. Es profesora en la Cátedra de Historia Social Latinoamericana y en el Taller de Investigaciones en Sociología Histórica de América Latina en la carrera de Sociología de la misma Facultad. Fue becaria de la Secretaría de Ciencia y Técnica para la realización del proyecto "Corrupción y poder político en Argentina, 1886-1890" y becaria de categoría Doctorado de la misma institución para la realización del proyecto "Cambio social y ciudadanía femenina en la coyuntura de 1930, perspectiva comparada de Argentina, Brasil y Uruguay". Investiga temas vinculados con la ciudadanía y el cambio social en América Latina desde la perspectiva de la Sociología histórica y de género. Se ha desempeñado como profesora en cursos de posgrado en la UBA y en otras universidades del país. Recientemente ha publicado Ciudadanas incapaces. La construcción de los derechos civiles de las mujeres en el Cono Sur (2012) y, en coautoría con Waldo Ansaldi, Historia de América Latina, una perspectiva sociológico-histórica 1880-2006 (2006).

Mirta Zaida Lobato. Doctora en Historia por la Universidad de Buenos Aires. Es profesora e investigadora en la Facultad de Filosofia y Letras, Universidad de Buenos Aires. Su área de investigación es el mundo del trabajo (instituciones estatales laborales, cultura obrera y relaciones de género). Es fundadora y miembro del Consejo de Dirección de Entrepasados (Revista de Historia) y de Mora (Revista del Instituto Interdisciplinario de Estudios de Género). Ha sido investigadora visitante en las universidades de Duke e Indiana, en los Estados Unidos; profesora en las universidades de Mar del Plata, Rosario, San Martín y en FLACSO; y ha recibido varios premios y becas de investigación de instituciones de prestigio, como la beca John Simon Guggenheim el año 2006. Ha publicado numerosos artículos en el país y en el extranjero. Es autora de La prensa obrera (2009), ¿Tienen derechos las mujeres? Política y ciudadanía en la argentina del siglo XX (2008), Historia de las trabajadoras en la Argentina, 1869-1960 (2007), La vida en las fábricas. Trabajo, protesta y política en una comu- 
nidad obrera, Berisso (1904-1970) (2001 y 2004), María Eva Duarte de Perón. Evita (1919-1952) (2003); coautora del Atlas Histórico de la Argentina (2000) y La protesta social en la Argentina (2003); editora de Buenos Aires. Manifestaciones, fiestas y rituales en el siglo XX (2011) y Cuando las mujeres reinaban. Belleza, virtud y poder en la Argentina del siglo xx (2005); y directora del vol. V de la Nueva Historia Argentina, El Progreso, la modernización y sus límites (1880-1916) (2000).

Flavia Macías. Investigadora del CONICET-Centro Científico Tecnológico-Instituto Superior de Estudios Sociales (CONICET/Universidad Nacional de Tucumán). Es especialista en Historia política argentina del siglo xix, con especial referencia a la región norte. En sus investigaciones aborda el problema de la construcción republicana decimonónica desde la óptica militar, poniendo especial atención en la formación de las milicias y en su funcionamiento político. Ha publicado artículos en diferentes revistas científicas nacionales e internacionales y ha participado de obras y libros colectivos. Entre ellos, “De ‘cívicos' a 'guardias nacionales'. Un análisis del componente militar en el proceso de construcción de la ciudadanía. Tucumán Argentina, 18401860" (2007) y "Política, Guardia Nacional y ciudadanos en armas. Tucumán, 1862-1868” (2011). Forma parte de diferentes proyectos de investigación con sede en Argentina y en España.

Helen Palma Pinedo. Licenciada en Antropología por la Pontificia Universidad Católica del Perú (PUCP). Ha participado en diversas investigaciones sobre temas de salud en poblaciones urbanas y rurales, así como en temas de niñez y antropología laboral. Actualmente forma parte del equipo técnico del Centro Nacional de Salud Intercultural (CENSI) del Ministerio de Salud del Perú, en el que desarrolla investigaciones y participa en intervenciones sobre interculturalidad en salud en comunidades indígenas andinas y amazónicas. Fue ganadora de las becas PAIN (PUCP) e IME (Grade) en el año 2007.

Juan Suriano es doctor en Historia. Ha dictado cursos en numerosas universidades nacionales y extranjeras. Actualmente es profesor titular regular de Historia Social Argentina en la Universidad Nacional de San Martín. En la misma institución se desempeña como director del la Maestría y el Doctorado en Historia.

Ha publicado numerosos artículos en revistas nacionales e internacionales. Entre otros libros es autor de: Atlas Histórico de la República Argentina (2000), La cuestión social en Argentina, 1870-1943 (2000), Anarquistas. Cultura y política 
libertaria en Buenos Aires, $1890-1910$ (2001) (versión inglesa, 2010), La protesta social en Argentina (2003), Dictadura y democracia. Historia Argentina Contemporánea, 1976-2000 (dir., 2005), El anarquismo argentino, 1880-1930 (2005), Las políticas sociales argentinas en perspectiva histórica (en colaboración con Daniel Lvovich, 2006), La temprana cuestión social en Argentina (en colaboración con Pilar González Bernardo y Ricardo González Leandro, 2010). Es fundador y director desde 1991 de Entrepasados, Revista de Historia.

Sofia Venturoli. Doctora en Antropología por la Universidad de Bolonia, Italia, y maestra en Social Anthropology and Amerindian Studies por la Universidad de St. Andrews, Escocia, es actualmente investigadora en el Departamento de Ciencias Políticas y Sociales de la Universidad de Bolonia. Ha coordenado las investigaciones antropológicas y etnohistóricas del Proyecto "Antonio Raimondi" en el área andina del departamento de Ancash, Perú (Universidad de Bolonia, Ministerio de Asuntos Exteriores de Italia). Ha desarrollado investigaciones antropológicas en el marco del proyecto "Río La Venta" en el área zoque del Chiapas, México (Universidad de Bolonia, Ministerio de Asuntos Exteriores de Italia). Ha coordinado un proyecto de antropología visual sobre eventos rituales en Italia, financiado por el CNR (Consiglio Nazionale delle Ricerche). Ha coordinado el proyecto de investigación y cooperación al desarrollo "ARTS. Artes Tradicional para el Desarrollo" en la provincia de Huari, Ancash, Perú. Ha publicado varios artículos científicos, monografias y coordinado varios libros colectivos; entre los más recientes: Ilpaesaggio come testo. La creazione di un'identitàtra territorio e memoria nell'area andina (2005), Religióni del Peruantico (2006), Los hijos de Huari. Historia y etnografía de tres pueblos andinos (2011), Espacios, Tradiciones y cambios en la provincia de Huari. Ecos desde la Escuela de etnografía del Proyecto "Antonio Raimondi" (2012).

Francesco Zanotelli es doctor en Antropología por la Universidad de Turín (Italia).Actualmente es investigador asociado en el SUS (Departamento de Ciencias Sociales y Humanas) de la Universidad de Messina, donde imparte cursos de Antropología cultural y Antropología cognitiva. Es miembro, por la misma universidad, del consejo científico del Doctorado en Antropología y Estudios Histórico-Lingüísticos. En su pesquisa antropológica, el tema de la definición local del valor económico de la persona adquiere un papel central y constante, siendo investigado en diferentes ámbitos y contextos socio-ambientales: poblaciones rurales mexicanas (estado de Jalisco) e indígenas (ikojts del Istmo, estado de Oaxaca), así como en poblaciones urbanas de Italia. Des- 
de hace más de quince años investiga en México los procesos de interacción entre las políticas económicas globales y las medidas locales de sobrevivencia, con un enfoque especifico hacia los intercambios financieros (finanzas populares, microcrédito). En Italia, ha desarrollado investigaciones sobre la interacción entre políticas públicas y seguridad social, con un enfoque sobre las nuevas dinámicas demográficas y de parentesco. Siempre alrededor del área antropológico-económica, otro tema conforma su perfil de investigador y estudioso: la reflexión en torno a las prácticas y políticas de la cooperación transnacional. Es autor de diversas monografias y artículos; entre ellas: Santo Dinero (2006), Scelte di famiglia (2010), Subire la cooperazione? (2008), La cura e ilpotere (2010) y Di terra e di dipietra (2012). 
